\section{To: (Receiving Organization) Distribution}

5. Proj./Prog./Dept./Div.:

19100

\section{Originator Remarks:}

For Approval and Release.

11. Receiver Remarks:
3. From: (originating Organization) Advanced Fuel Facilities

Transition

6. Design Authority/ Design Agent/Cog. Engr.

J. E. Ham
4. Related EDT No.

618474

7. Purchase Order No.:

$N / A$

9. Equip./Component No.: N/A

10. System/Bldg./Facility: PRTR/309

12. Major Assm. Dwg. No.: N/A

13. Permit/Permit Application No.: N/A

14. Required Response Date: August 15, 1996

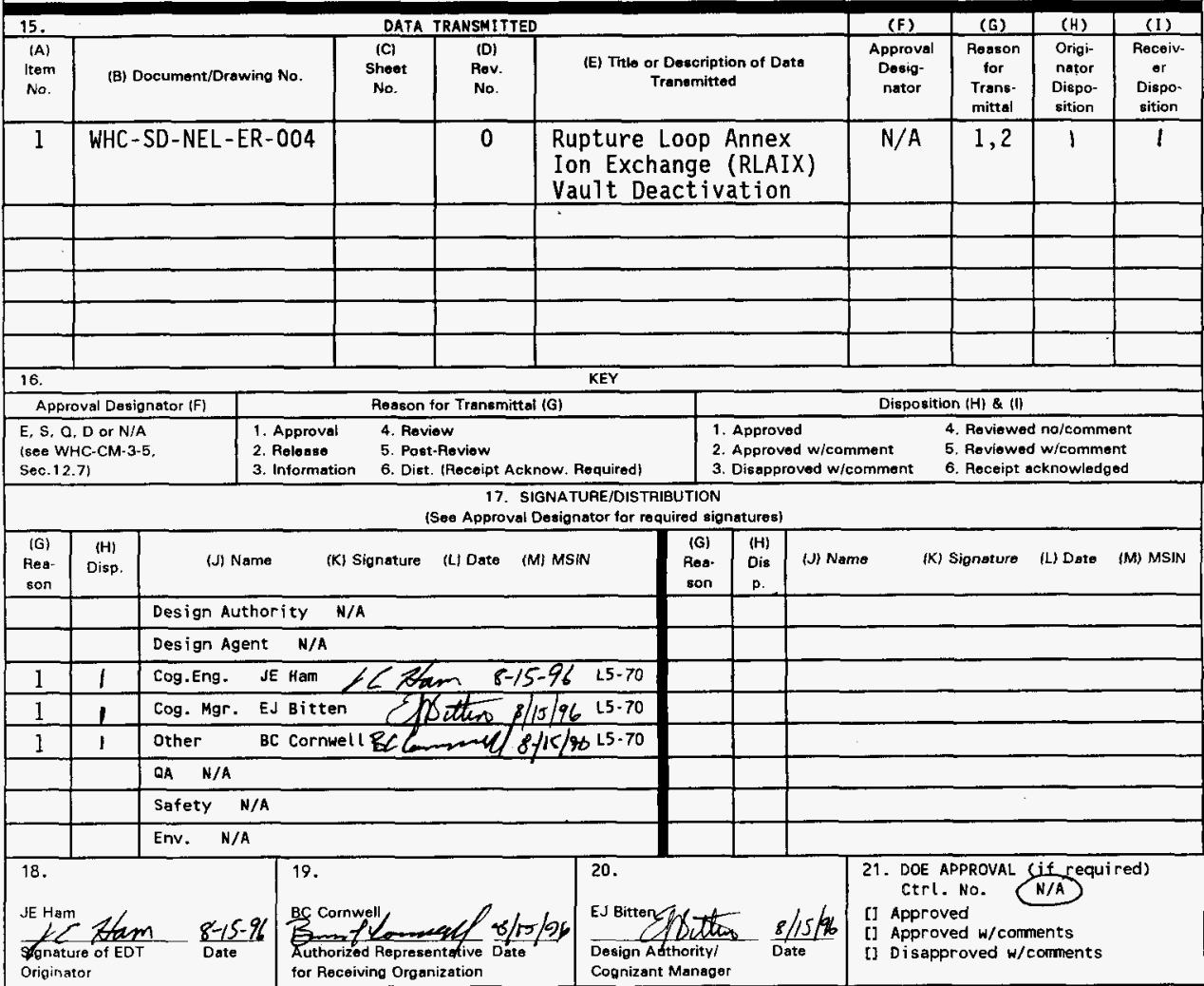




\title{
Rupture Loop Annex Ion Exchange (RLAIX) Vault Deactivation
}

\author{
J. E. Ham \\ West inghouse Hanford Company, Richland, WA 99352 \\ U.S. Department of Energy Contract DE-AC06-87RL10930 \\ $\begin{array}{llll}\text { EDT/ECN: } & 618474 & \text { UC: } 510 \\ \text { Org Code: } & 19100 & \text { Charge Code: } & \\ \text { B\&R Code: } & \text { EX7003000 } & \text { Total Pages: } & 142\end{array}$
}

Key Words: PRTR, Rupture, Loop, Annex, Ion, Exchange, RLAIX, Vault, Columns, Deactivation, Cleanout, Stabilization, AFFT, Turnover, D\&D

Abstract: This engineering report documents the deactivation, stabilization and final conditions of the Rupture Loop Annex Ion Exchange (RLAIX) Vault located northwest of the 309 Building's

Plutionium Recycle Test Reactor (PRTR). Twelve ion exchange columns, piping debris, and column liquid were removed from the vault, packaged and shipped for disposal. The vault walls and floor were decontaminated, and portions of the vault were painted to fix loose contamination. Process piping and drains were plugged, and the cover blocks and rain cover were installed. Upon closure, the vault was empty, stabilized, isolated.

TRADEMARK DISCLAIMER. Reference herein to eny specific comercial product, process, or service by trade name, trademark, manufacturer, or otherwise, does not necessarily constitute or imply its endorsement, recommendation, or favoring by the United States Government or any agency thereof or its contractors or subcontractors.

Printed in the United States of America. To obtain copies of this document, contact: WHC/BCS Document Control Services, P.0. Box 1970, Mailstop H6-08, Richland WA 99352, Phone (509) 372-2420; Fax (509) 376-4989.
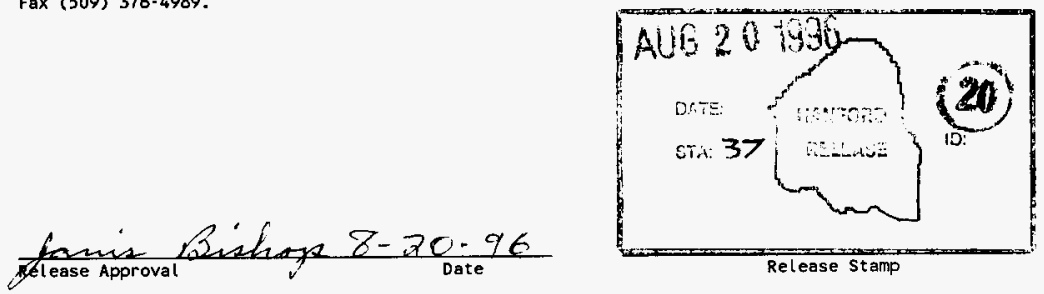

Approved for Public Release 


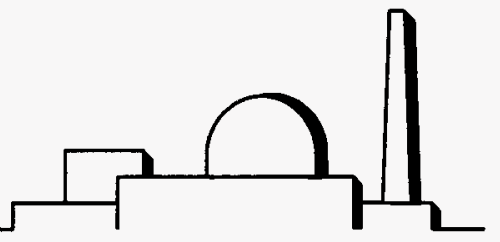

\section{Rupture Loop Annex Ion Exchange (RLAIX) Vault Deactivation}

Author

J. E. Ham

Technical Writer

D. L. Harris

Date Published

August 1996

Westinghouse Hanford Company

Plutonium Recycle Test Reactor

Richland, Washington 


\section{EXECUTIVE SUMMARY}

This report documents the deactivation of the Rupture Loop Annex Ion Exchange (RLAIX) vault. The RLAIX vault, located northwest of the 309 Building dome within the 300 Area, is part of the Plutonium Recycle Test Reactor (PRTR). The PRTR has been declared surplus by the U.S. Department of Energy (DOE) and is scheduled for transition to decontamination and decommissioning (D\&D). Advanced Fuel Facilities Transition (AFFT), previously known as PRTR Transition, of Westinghouse Hanford Company (WHC) is responsible for the transition of the PRTR to D\&D in 1998.

The RLAIX vault was part of a test loop that tested intentionally defected fuel in the reactor. The vault, measuring $3.96 \mathrm{~m} \times 7.10 \mathrm{~m} \times 4.57 \mathrm{~m}\left(13^{\prime} \times 23.3^{\prime} \times 15^{\prime}\right)$, was expected to contain three to four columns approximately $3.3 \mathrm{~m}\left(11^{\prime}\right)$ in height and ranging from $0.53 \mathrm{~m}$ to $0.71 \mathrm{~m}\left(1.75^{\prime}\right.$ to $2.3^{\prime}$ ) in diameter. The vault was opened in August, 1995 for initial characterization (Ham 1996a), approximately three decades after the reactor's initial use. Twelve ion exchange (IX) columns were found in the vault along with miscellaneous piping equipment and debris. Seven of the twelve columns were found to contain process liquid. Upon initial entry radiological surveys indicated a maximum dose rate of $2.5 \mathrm{rem} / \mathrm{hr}$, and contamination levels of $350 \mathrm{dpm} / 100 \mathrm{~cm}^{2}$ smearable alpha, $7,000 \mathrm{dpm}$ direct alpha, and $1,000 \mathrm{dpm} / 100 \mathrm{~cm}^{2}$ smearable beta-gamma.

The RLAIX vault was again reopened on May 1, 1996 for cleanout. Cleanout of the vault entailed: removing, sampling, packaging, and disposing the liquid taken from seven IX columns; preparing, removing, packaging, and disposing all twelve IX columns and miscellaneous debris/equipment; and, stabilizing smearable contamination remaining within the RLAIX vault. During decontamination, smearable contamination levels up to $70,000 \mathrm{dpm} / 100 \mathrm{~cm}^{2}$ beta-gamma and $28,000 \mathrm{dpm} / 100 \mathrm{~cm}^{2}$ alpha were found.

Approximately 2,650 liters (700 gallons) of slightly radiologically contaminated, nonhazardous water was removed from the seven columns and shipped to the 340 Liquid Waste Handling Facility for disposal. The twelve IX columns and miscellaneous debris were packed into three $1.83 \mathrm{~m} \times 1.83 \mathrm{~m} \times 3.66 \mathrm{~m}\left(6^{\prime} \times 6^{\prime} \times 12^{\prime}\right)$ waste containers and shipped to the Solid Waste burial grounds. Stabilization efforts reduced the RLAIX vault's smearable contamination levels to $<1,000 \mathrm{dpm} / 100 \mathrm{~cm}^{2}$ beta-gamma and less than background alpha $(<3 \mathrm{cpm})$. The vault's background dose rate dropped to $<0.5$ $\mathrm{mrem} / \mathrm{hr}$.

Cleanout of the RLAIX vault was performed safely and without incident. The task was officially completed on May 30,1996, finishing two months prior to the DOE Richland Field Office (DOE-RL) Milestone \# B79-96-903 (Hulvey 1995) date of July 31, 1996. 
1.0 INTRODUCTION

Page 1

Page 1 Page 1 Page 2

Page 3 Page 3 Page 4 Page 7

Page 12 Page 12 Page 12 Page 13

3.3 WASTE ACCEPTANCE

Page 14

4.0 CONCLUSION

Page 15 


\section{BUILDING}

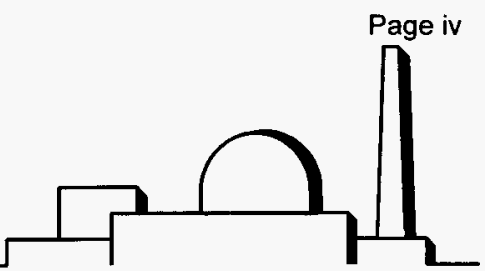

AdVANCED FuEL FaciLITIES Transition

FIGURES

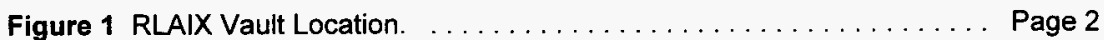

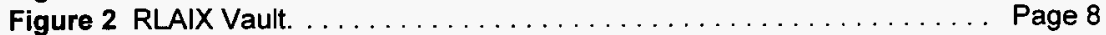

Figure 3 Waste Container Box $\# 1 \ldots \ldots \ldots \ldots \ldots \ldots \ldots \ldots \ldots$ Page 9

Figure 4 Waste Container Box $\# 2 \ldots \ldots \ldots \ldots \ldots \ldots \ldots \ldots \ldots$ Page 9

Figure 5 Waste Container Box \#3 .................... Page 10

TABLES

Table 1 Road Closure Checklist $\ldots \ldots \ldots \ldots \ldots \ldots \ldots \ldots$ Page 4 


\title{
ACRONYMS AND ABBREVIATIONS
}

\author{
AFFT Advanced Fuel Facilities Transition \\ AGEC Applied Geotechnical Engineering and Construction Inc. \\ AHA activity hazard analysis \\ ALARA as low as reasonably achievable \\ ATG Allied Technology Group \\ $\mathrm{BHI}$ \\ $\mathrm{cm}^{2}$ \\ Bechtel Hanford Inc. \\ $\mathrm{cpm}$ \\ centimeters squared \\ D\&D \\ counts per minute \\ DOE \\ Decontamination and Decommissioning \\ DOE-RL DOE Richland Field Office \\ DOT U. S. Department of Transportation \\ dpm disintegration per minute \\ ERC \\ FERTF \\ Environmental Restoration Contractor \\ HEPA \\ hr hour \\ Fuel Element Rupture Test Facility \\ ICF-KH Inner City Finance - Kaiser Hanford \\ IX \\ $\mathrm{km}$ \\ ion exchange \\ mrem \\ PIC \\ PNNL \\ PPE \\ PRTR \\ kilometer \\ milli-rem \\ person-in-charge \\ Pacific Northwest National Laboratory \\ personal protective equipment \\ PTRAEU \\ Plutonium Recycle Test Reactor \\ RCA \\ RCT \\ rem \\ RLA \\ Portable Temporary Radioactive Air Exhaust Unit \\ Radiologically Controlled Area \\ Radiological Control Technician \\ Roentgen-equivalent man \\ RLAIX \\ Rupture Loop Annex \\ RSR \\ RWP \\ SAP \\ Rupture Loop Annex Ion Exchange \\ radiation survey report \\ radiation work permit \\ SEP \\ SML \\ sampling and analysis plan \\ safety evaluation for packaging \\ WEO \\ Sampling Mobile Labs \\ WHC \\ Waste Environmental Operations \\ Westinghouse Hanford Company
}




\subsection{INTRODUCTION}

\subsection{OBJECTIVE}

This report documents the deactivation of the RLAIX vault. The RLAIX vault is part of the PRTR which has been declared surplus by the DOE and is scheduled for transisiton to D\&D. This supporting document provides details of the activities taken to properly deactivate and stabilize the RLAIX vault in preparation for turnover to the Hanford Site Environmental Restoration Contractor (ERC) (Cornwell 1996).

\subsection{WORK SCOPE}

Deactivation and stabilization of the vault entailed:

- Removing, sampling, and packaging liquid from seven IX columns for disposal;

- $\quad$ Preparing, removing, and packaging twelve IX columns for disposal;

- Removing and packaging miscellaneous debris and dirt from the vault, and;

- Stabilizing smearable contamination remaining within the vault.

A detailed work description is provided in work procedure 309-WP-96-002, Revision 0 , Rupture Loop Annex lon Exchange (RLAIX) Vault Cleanout (Ham 1996b). 


\subsection{BACKGROUND}

The RLAIX vault is located northwest of the 309 Building PRTR containment dome within the 300 Area (Figure 1). The 300 Area is located within the Hanford Site on the west bank of the Columbia River approximately 1.6 river $\mathrm{km}$ (1 river mile) upstream and 1.6 road $\mathrm{km}$ (1 road mile) north from the City of Richland, in the southeastern corner of Washington state.

The PRTR was completed in early 1960 as the operating test reactor in the Hanford Works Plutonium Fuels Utilization Program. Criticality was achieved in October 1960, and full power was reached in May 1961. In

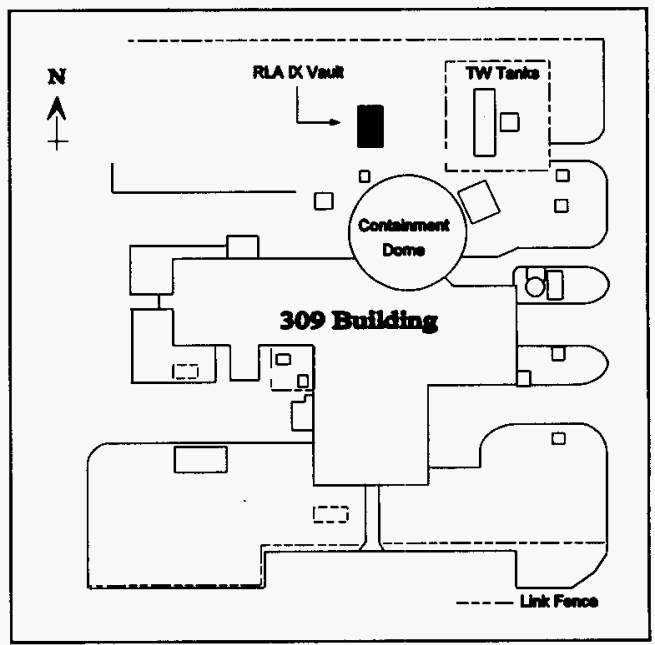

Figure 1 RLAIX Vault Location. 1963, operations of the Fuel Element Rupture Test Facility (FERTF) began. The FERTF was a pressurized, light-water-cooled loop which used one of the 85 process tubes within the PRTR calandria to test pre-defective fuel elements. The RLAIX vault contained IX columns used to clean-up the fuel and fission products from the test loop. An accident occurred in 1965 when some test fuel failed excessively, causing failure of the process tube which contaminated the reactor's moderator coolant system. The RLAIX test loop and the PRTR main cleanup systems were both contaminated with fuel residual and fission products.

The RLAIX vault was opened in August 1995 for entry and characterization. A detailed description of this task and the vault contents are provided in WHC-SD-NEL-ER-002, Revision 0, RLA lon Exchange Vault Entry and Characterization (Ham 1996a). This document served as the basis for the RLAIX vault deactivation activities contained in this supporting document. 


\subsection{DESCRIPTION}

\subsection{PROJECT MANAGEMENT}

Advanced Fuel Facilities Transition (AFFT) of WHC provided project management oversight and control of the RLAIX vault deactivation activities. The AFFT Manager has overall responsibility for the RLAIX vault and approval authority for RLAIX vault related work documents and permits. The AFFT Cognizant Engineer developed and approved deactivation plans, work packages, and procedures; directed project management activities; and, coordinated support work forces.

Applied Geotechnical Engineering and Construction, Inc. (AGEC) provided the staff and equipment that performed the grouting and stabilization activities.

Bechtel Hanford Inc. (BHI), Environmental Restoration Contractor (ERC) for the Hanford Site, provided the following personnel along with associated equipment: Senior Engineer, person-in-charge (PIC), field safety monitoring representative, and D\&D workers.

Department of Energy-Richland Operations Office (DOE-RL) provided project surveillants to monitor performance objectives (Chapin and Ruhlman 1996).

Inner City Finance-Kaiser Hanford (ICF-KH) provided the crane and associated equipment along with the crane and rigging services crew and supervisor.

Pacific Northwest National Laboratory (PNNL) provided the necessary sample analysis.

Westinghouse Hanford Company (WHC) provided support from the following organizations: 340 Liquid Waste Handling Facility; Air and Water Services; Environmental Compliance; Liquid Effluent Services; Project Services; Radiological Control; Safety; Sampling Mobile Labs (SML); Solid Waste Services; Transportation and Packaging, and; Waste Environmental Operations (WEO). 


\subsection{WASTE PACKAGING AND SHIPMENT REQUIREMENTS}

The planning for this project was divided into two essential categories: (1) RLAIX vault cleanout and (2) waste packaging, transportation, and disposal. In addition to project management and oversight, AFFT also planned and implemented the vault cleanout activities. Waste Environmental Operations was selected to manage the waste packaging, transportation, and disposal under AFFT's direction and field work coordination.

Due to the nature of the waste, a safety evaluation for packaging (SEP) would be necessary. The SEP (Mercado 1996) analyzed transportation and packaging conditions of the onsite shipment of waste. It evaluated package contents, radiological risk, containment, shielding, criticality, package structure, thermal properties, gas generation, package tie down, and accident scenarios. The SEP also developed requirements that rigidly defined the packaging and shipment of the RLAIX vault waste. A summary of these requirements are shown as a road closure checklist in Table 1.

Table 1 Road Closure Checklist

\begin{tabular}{||l|l||}
\hline \multicolumn{1}{|c|}{ Requirement } & SEP Source \\
\hline $\begin{array}{l}\text { This SEP will be used to support the shipment of three boxes from the rupture loop } \\
\text { annex vault near the 309 building in the 300 Area to LLW burial in the 200 West Area. }\end{array}$ & pg A7-1, sec \\
7.2
\end{tabular}




\section{BUILDING}

AdVANCED FuEL Facilities Transition

\begin{tabular}{|c|c|}
\hline Requirement & SEP Source \\
\hline The maximum gross weight of a single box is $27,216 \mathrm{~kg}(60,000 \mathrm{lb})$. & $\begin{array}{l}\operatorname{pg} A 2-1, \text { sec } \\
2.4\end{array}$ \\
\hline $\begin{array}{l}\text { The boxes shall be surveyed prior to shipment. Localized hot spots shall be identified, } \\
\text { and appropriate administrative controls shall be implemented as necessary to assure as } \\
\text { low as reasonably achievable (ALARA) practices. }\end{array}$ & $\begin{array}{l}\operatorname{pg} \mathrm{B} 1-1, \mathrm{sec} \\
1.2\end{array}$ \\
\hline $\begin{array}{l}\text { During transfer conditions, removable contamination on the exterior surfaces of the } \\
\text { boxes shall not exceed the U. S. Department of Transportation (DOT) limits shown in } \\
\text { Table A4-1 when measured per } 49 \text { CFR } 173.443 \text { (a) (CFR 1995a). }\end{array}$ & $\begin{array}{l}\operatorname{pg} A 4-2, \text { sec } \\
4.3\end{array}$ \\
\hline The shipment will require an overweight load permit. & $\begin{array}{l}\operatorname{pg} A 4-2, \text { sec } \\
4.3\end{array}$ \\
\hline $\begin{array}{l}\text { Three transport vehicles, } 13,608 \mathrm{~kg}(30,000 \mathrm{lb}) \text { minimum weight per truck and trailer, } 1 \\
\text { box per trailer. }\end{array}$ & $\begin{array}{l}\text { pg B3-1, sec } \\
3.1\end{array}$ \\
\hline $\begin{array}{l}\text { Each box shall be transported on a trailer of appropriate capacity for the package weight } \\
27,216 \mathrm{~kg}(60,000 \mathrm{lb}) \text {. }\end{array}$ & $\begin{array}{l}\operatorname{pg} A 4-1, \text { sec } \\
4.1\end{array}$ \\
\hline $\begin{array}{l}\text { Each transport vehicle shall conform to DOT annual inspection requirements found in } 49 \\
\text { CFR } 396.3 \text { (CFR 1995b) and } 49 \text { CFR } 396.17 \text { (CFR 1995c). }\end{array}$ & $\begin{array}{l}\operatorname{pg} A 4-1, \sec \\
4.3\end{array}$ \\
\hline $\begin{array}{l}\text { Each transport vehicle will be equipped with a fire extinguisher capable of extinguishing } \\
\text { a Class } A, B, \text { or } C \text { fire. The driver of the vehicle will be trained and qualified to use the } \\
\text { fire extinguisher. }\end{array}$ & $\begin{array}{l}\text { pg A4-2, sec } \\
4.3\end{array}$ \\
\hline $\begin{array}{l}\text { In addition, bracing shall be used to prevent longitudinal shifting during deceleration. } \\
\text { Bracing will include an I beam at the front of the box, attached to the trailer. The bracing } \\
\text { assembly (beam, attachment devices and attachment points) shall be able to withstand } \\
\text { a load of } 17,237 \mathrm{~kg}(38,000 \mathrm{lb}) \text { without yielding. }\end{array}$ & $\operatorname{pg}_{4.2} \mathrm{A4}-1, \mathrm{sec}$ \\
\hline $\begin{array}{l}\text { Each box shall be tied down using six nylon straps with binders. The straps and binders } \\
\text { shall have a minimum working load of } 5,443 \mathrm{~kg}(12,000 \mathrm{lb}) \text {. }\end{array}$ & $\begin{array}{l}\operatorname{pg} A 4-1, \mathrm{sec} \\
4.2\end{array}$ \\
\hline \multicolumn{2}{|l|}{$\begin{array}{l}\text { The rigging for each box shall remain with the box, prepared for hoisting and placement } \\
\text { of each box in the burial grounds. }\end{array}$} \\
\hline $\begin{array}{l}\text { All rigging hardware, tie down straps, tension devices, attachments, and associated } \\
\text { equipment will be visually inspected to ensure that there is no damage or deterioration. }\end{array}$ & $\begin{array}{l}\operatorname{pg} A 4-1, \text { sec } \\
4.3\end{array}$ \\
\hline $\begin{array}{l}\text { Each box shall be oriented with its long axis in the direction of travel. The straps shall } \\
\text { run over the top of the box in a direction perpendicular to the direction of travel and shall } \\
\text { be placed at regular intervals. }\end{array}$ & $\begin{array}{l}\operatorname{pg} A 4-1, \text { sec } \\
4.2\end{array}$ \\
\hline
\end{tabular}




\section{BUILDING}

AdVANCED Fuel Facilities Transition

\begin{tabular}{|l|l||}
\hline \multicolumn{1}{|c|}{ Requirement } & SEP Source \\
\hline $\begin{array}{l}\text { The offsite limit of } 2 \text { mrem/hr in any normally occupied space in each transport vehicle } \\
\text { shall not be exceeded. }\end{array}$ & $\begin{array}{l}\text { pg B1-1, sec } \\
1.2\end{array}$ \\
\hline $\begin{array}{l}\text { Transport vehicle speed will be limited to } 48 \mathrm{~km} \text { (30 miles) per hour unless a lower } \\
\text { speed is posted. }\end{array}$ & $\begin{array}{l}\text { pg A4-1, sec } \\
4.3\end{array}$ \\
\hline $\begin{array}{l}\text { The boxes will not be transferred during periods of inclement weather; i.e., winds in } \\
\text { excess of } 56 \mathrm{~km} \text { (35 miles) per hour, heavy driving rain, blowing dust or fog that results } \\
\text { in poor visibility, or slippery roads. }\end{array}$ & $\begin{array}{l}\text { pg A4-1, sec } \\
4.3\end{array}$ \\
\hline $\begin{array}{l}\text { In the event of an accident involving the transport vehicle, onsite emergency response } \\
\text { guidelines will be followed. }\end{array}$ & $\begin{array}{l}\text { pg A4-2, sec } \\
4.3\end{array}$ \\
\hline
\end{tabular}




\subsection{VAULT CLEANOUT ACTIVITIES}

Work was conducted in accordance with work package 3B-96-00014/W, which contained facility work plans and procedures, data tables, checklists, figures, activity hazard analysis (AHA), radiation survey reports (RSR), radiation work permits (RWP), etc. Work procedure 309-WP-96-002, Revision 0, Rupture Loop Annex Ion Exchange (RLAIX) Vault Cleanout (Ham 1996b) provided instruction for the cleanout activities.

A prejob meeting was held on April 30, 1996 and cleanout activities began on May 1, 1996. Prejob briefings were also performed daily by the PIC to discuss the workday activities and safety issues. An agreement was made to start work earlier in the morning to avoid the higher temperatures of late afternoon. Every morning, the rain cover was removed, guardrails were assembled, and a portable exhauster was installed and activated. Vault oxygen and gas measurements were taken on days when entries were made.

Continuous support was provided by a Radiological Control Technician (RCT) and the PIC. The cognizant engineer, safety personnel, SML, crane and rigging services, D\&D workers, and others also provided support. Boundaries were established for access control to the general work area and radiologically controlled areas (RCA). Personal protective equipment (PPE) required for the general work area (hard hats, substantial footwear, safety eyeglasses) was posted on boundary signs. The PPE required for the RCA was stated in the RWPs.

At the end of the workday's activities, the vault was secured. The inner guardrails were removed to allow for the replacement of the rain cover. Equipment and material were stored in designated areas, and tools were picked up. Barricades and signs were checked to ensure access was limited and warnings were posted.

\section{Day 1 (May 1.1996)}

This day was dedicated to job site preparation. Equipment and materials were staged and cover blocks were removed from the RLAIX vault and placed in the Tank Farm laydown area to be used as shielding for the waste containers once filled. A Portable Temporary Radioactive Air Exhaust Unit (PTRAEU) was used to exchange the air in the vault and provide High-Efficiency Particulate Air (HEPA) filtration. The 12 RLAIX columns were moved into position for the 
pumping of the internal liquids of seven columns. The working platform was setup and the waste container boxes $\left[1.83 \mathrm{~m} \times 1.83 \mathrm{~m} \times 3.66 \mathrm{~m}\left(6^{\prime} \times 6^{\prime} \times 12^{\prime}\right)\right]$ were staged. Refer to Figures A-1 through A-4 of Appendix A, and Figure 2 below.

\section{Day 2 (May 2. 1996)}

Liquid was pumped, using a peristaltic pump, from two columns, R2 and R5/RLIX-1 (Figure 2), into 208 liter ( 55 gallon) drums which were staged on spill pallets. An in-line filter was used to reduce solids. An absorbent was added to each column to meet burial requirement. See Figures $A-5$ and $A-6$ of Appendix A.

\section{Day 3 (May 3, 1996)}

Liquid was pumped from two more RLAIX columns, L3 and R3. Pumping continued with columns $L 1, L 2$, and $R 3$, however, resin beads were encountered. A decision was made to rotate subsequent pumping between the three columns in order to allow the beads

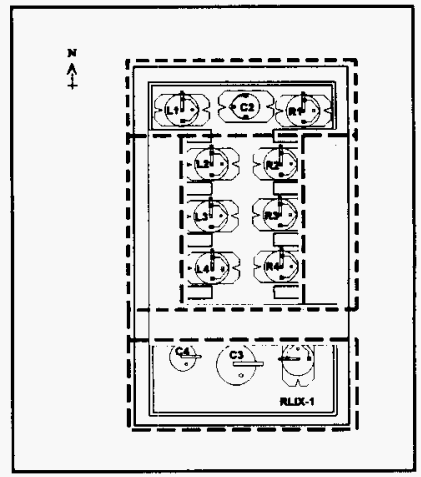

Figure 2 RLAIX Vault. time to settle and thus maximize the amount of liquid obtained. Five centimeter (two inch) spacers were delivered and installed on the sides of the three waste container boxes to ensure the waste would meet packaging requirements.

\section{Day 4 (May 6. 1996)}

Pumping of liquid from the three remaining RLAIX columns was completed and absorbent was added to the columns. A total of 14208 liter (55-gallon) drums were filled with column liquid. Five centimeters (two inches) of grout was poured into the bottom of the waste container boxes in preparation for column loading.

Dax 5 (May 7.1996 )

The 14 drums of liquid were each sampled and then the samples were combined to form a composite sample. This sample was transported to PNNL's 325 Laboratory for analysis. Due to high wind gusts, the loading of columns into the waste container boxes was postponed until the following workday. 
309 BUILDING

ADVANCED FUEL FACILITIES TRANSITION

Day 6 (May 8, 1996)

The 12 columns were loaded into the three waste container boxes (four columns to one box): L1, L3, R1, and R2 into Waste Container Box \#1 (Figure 3); C2, L2, L3, and R3 into Waste Container Box \#2 (Figure 4), and; C3, C4, R4, and R5 into Waste Container Box \#3 (Figure 5). For ALARA reasons, the three boxes were hoisted and moved east of the RLAIX vault area to the tank farm storage area (Figure 1) where they were shored and shielded from the west with RLAIX vault cover blocks. Waste Container Box \#3 also contained the miscellaneous jumpers, filter, and debris from the RLAIX vault. The vault was now clear of columns, debris, etc., and was ready for dirt removal and decontamination. Refer to Figures A-7 through A-9 of Appendix A.

\section{Day 7 (May 9. 1996)}

Grout was injected into two empty columns, $\mathrm{C} 3$ and $\mathrm{C} 4$, to fill the void space. The waste container lid was then replaced. The first lift of grout [3.4 $\left.\mathrm{m}^{3}\left(120 \mathrm{ft}^{3}\right)\right]$ was poured into each of the three waste containers through nozzle fittings in the lid. The displaced air in the container passed through a HEPA filter also installed to the container lid. See Figures A-11 and A-12 of Appendix A.

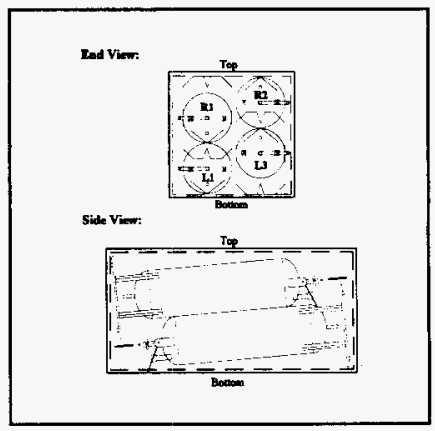

Figure 3 Waste Container Box \#1

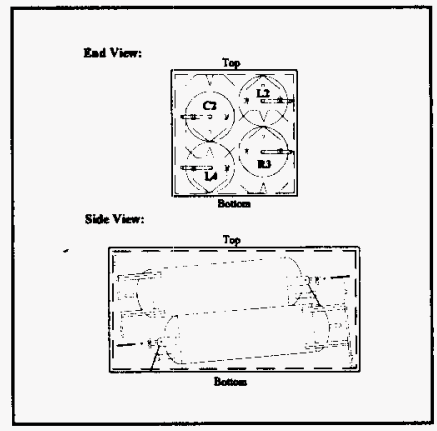

Figure 4 Waste Container Box \#2

Dirt and small, loose material were removed from the vault in two steps. First, based on radiation surveys, the nonradioactive material was removed using a large Euroclean HEPA vacuum. Then, 
the "hot spots" were cleaned using a small hand-held Euroclean HEPA Vacuum. Radiological surveys indicated that the south section of the vault had the highest amount of contamination located on the wall below the ledge with the pipe jumper nozzles.

After removing material and decontaminating by wipe down, a layer of paint was applied to the floor and walls of the south section of the vault where loose contamination was found. See Figures A-13 and A-14.

\section{Day 8 (May 13, 1996)}

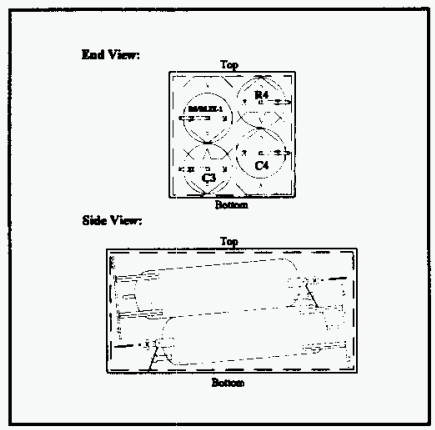

Figure 5 Waste Container Box \#3

After allowing the first lift of grout to cure, the second lift was poured $\left[3.4 \mathrm{~m}^{3}\left(120 \mathrm{ft}^{3}\right)\right]$. The grout was poured in lifts to keep the columns from floating and to keep the container from bulging. Smear surveys of the vault indicated that another layer of fixative would be necessary. However, due to rain, work activities were postponed until the next workday.

\section{Day 9 (May 14.1996)}

The third and final lift of grout was poured $\left[<1.6 \mathrm{~m}^{3}\left(<55 \mathrm{ft}^{3}\right)\right]$. An additional layer of paint was applied to the walls of the south section of the vault and to the nozzels on the south ledge. Smear surveys taken in the afternoon indicated that the contamination levels had been fixed to satisfactory conditions. The vault drain, which dumps to a sump in the Rupture Loop Annex (RLA) of the 309 Building, was plugged and grouted. Nozzles without plugs were plugged and all nozzels were painted. Refer to Figure A-15 of Appendix A.

\section{Day 10 (May 15, 1996)}

Dose rates from the three grouted waste containers were obtained by the RCT. Surveys indicated that the hottest spot on the three containers was $180 \mathrm{mrem} / \mathrm{hr}$ on the side of Waste Container \#2. Survey information was passed on to the burial grounds for waste receiving. Cover blocks from the vault were continued to be used as shielding. 
309 BUILDING

AdVANCEd Fuel Facilities Transition

\section{Day 11 (May 23, 1996)}

One last entry was made into the RLAIX vault to clean-up the floor due to the mess made by rain a week earlier. The vault cover blocks and rain cover were replaced on the RLAIX vault (Figure A-16 of Appendix A) and equipment and material were removed from the job site.

\section{Day 12 (May 30.1996$)$}

The three waste containers carrying 12 IX columns and debris from the RLAIX vault were weighed and loaded during swing shift (Figures $A-17$ and $A-18$ ). Each waste container was loaded onto a low-boy trailer and strapped down to transport specifications. Verification of the appropriate requirements were made and the three waste containers were transported to the Solid Waste burial grounds.

Activities to perform minor tasks occurred on May 16, 22, and 29, 1996. These activities took minimal time to complete and required only a few personnel. The associated RSRs for the entire task are in chronological order in Appendix C. The final condition of the RLAIX vault is recorded on RSR \#234322 dated May 14, 1996. 


\subsection{RESULTS AND DISCUSSION}

\subsection{RLAIX COLUMN LIQUID}

Advanced Fuel Facilities Transition requested PNNL to provide analytical support for the disposal of the RLAIX column liquids. A sampling and analysis plan (SAP) detailed the required analysis in Appendix D of 309-WP-96-002 (Ham 1996b). The RLAIX column liquid sample analysis results (Appendix $B$ ) were compared to limits set forth by the 340 Liquid Waste Handling Facility of the 300 Area. It was determined that the liquid was slightly radiologically contaminated non-hazardous water and met the requirements for transfer to the 340 Liquid Waste Handling Facility. The 340 Liquid Waste Handling Facility serves as an accumulation point for radiologically contaminate liquid. The liquid is further analyzed and then transferred to Tank Farms via railcar shipments.

The 14 drums of RLAIX column liquid were then shipped to the 340 Liquid Waste Handling Facility. The liquid was pumped from the drums and the drums were dried for transportation purposes. The empty drums were shipped to Allied Technology Group (ATG) for compaction and disposal at the Solid Waste burial grounds.

\subsection{VAULT CLOSURE}

The RLAIX vault was closed (cover blocks and rain cover installed) on May 23, 1996. The DOE-RL Milestone \# B79-96-903 (Hulvey 1995) was met on May 30, 1996, two months ahead of schedule when the waste containers were weighed and loaded onto trailers for shipment. A total of $12 \mathrm{IX}$ columns, piping debris, filter, jumpers, and dirt were removed from the vault. Loose contamination was fixed in place by layers of paint and entrance and exits to the vault were plugged or grouted. The final condition of the RLAIX vault consisted of a cleaned out, stabilized environment which was confirmed by pictures (Appendix A), video, and radiological survey data reports (Appendix C).

The survey reports show radiological contamination levels were as high as 70,000 $\mathrm{dpm} / 100 \mathrm{~cm}^{2} /$ beta-gamma and $28,000 \mathrm{dpm} / 100 \mathrm{~cm}^{2} /$ alpha and with contact dose rates up to $2.5 \mathrm{rem} / \mathrm{hr}$ at Column L3. After cleanout and stabilization, contamination levels 

background dose rate of $<0.5 \mathrm{mrem} / \mathrm{hr}$.

The RLAIX vault cleanout task was completed in a safe, ALARA manner consistent with WHC management practices. No injuries occurred.

\subsection{WASTE ACCEPTANCE}

The acceptance of the RLAIX vault waste by Solid Waste, which allowed the shipment to the Solid Waste burial grounds, was obtained through the Waste Specification System (Kirkpatrick and Oswald 1995). This system requires that generators characterize their waste with sufficient accuracy to allow for proper management. Additional information was necessary to complete the characterization of RLAIX vault waste. This information is documented in a Final Characterization Report located in Appendix D. The vault contents were determined to be low-level, category $\mid$ and category III, nonhazardous waste.

The characterization of each waste stream was documented on a Waste Certification Summary and Waste Specification Record. A Waste Stream Requirements Summary was used to ensure each waste stream (i.e. IX columns, step-off pad waste, etc.) met specific requirements. These summaries and records were submitted to Solid Waste in a Waste Portfolio for acceptance. A portion of the information contained in the Waste Portfolio submitted to Solid Waste is provided in Appendix E. To minimize duplication of information located in this supporting document, not all of the referenced attachments cited in the original Waste Portfolio are present in Appendix E, but they can, however, be found in 309-WP-96-002 (Ham 1996b). 


\subsection{CONCLUSION}

Westinghouse Hanford Company was successful in its efforts to deactivate and stabilize the RLAIX vault. Cleanout was accomplished by removing 12 IX columns (including liquid), miscellaneous piping equipment, and debris. Stabilization was reached by reducing contamination levels to $<1,000 \mathrm{dpm} / 100 \mathrm{~cm}^{2}$ beta-gamma, less than background $(<3 \mathrm{cpm})$ alpha, and a dose rate of $<0.5 \mathrm{mrem} / \mathrm{hr}$. In addition, the RLAIX vault floor drain, which leads to a sump in the 309 Building, was grouted.

The RLAIX vault solid waste was properly disposed of through the Waste Specification System and was determined to be non-hazardous, low level, category I and III waste. The liquid was determined to be non-hazardous, slightly radiologically contaminated water, and was properly disposed of via the 340 Liquid Waste Handling Facility.

The RLAIX vault cleanout activities were performed safely and without injury. The task was also completed two months prior to DOE-RL Milestone \#B79-96-903 (Hulvey 1995). 


\section{BUILDING}

\subsection{REFERENCES}

CFR, 1995a, Code of Federal Regulations: Transportation, "Contamination Control," Title 49, Part 173.443(a), Washington D.C.

CFR, 1995b, Code of Federal Regulations: Transportation, "Inspection, Repair, and Maintenance," Title 49, Part 396.3, Washington D.C.

CFR, 1995c, Code of Federal Regulations: Tranportation, "Periodic Inspection," Title 49. Part 396.17, Washington D.C.

Chapin, D. H. And Ruhlman W. A., 1996, Cleanout and Stabilization of the 309 Facility's PRTR RLAIX Vault, and Removal and Preparation for Shipment and Disposal of the 12 Spent RLAIX Columns, TPD-DHC-96-015, Department of Energy - Richland Operations Office, Richland, Washington.

Cornwall, B. C., 1996, 309 D\&D Criteria Completion Check List, WHC-SD-NEL-RD-001, Revision 0, Westinghouse Hanford Company, Richland, Washington.

Ham, J. E., 1996a, RLA Ion Exchange Vault Entry and Characterization, WHC-SD-NELER-002, Revision 0, Westinghouse Hanford Company, Richland, Washington.

Ham, J. E., 1996b, Rupture Loop Annex Ion Exchange (RLAIX) Vault Cleanout, 309-WP-96-002, Revision 0, Westinghouse Hanford Company, Richland, Washington.

Hulvey, R. K., 1995, Advanced Reactors Transition Fiscal Year 1996 Multi-Year Program Plan WBS 7.3, WHC-SD-FF-SSP-052, Revision 1, Program WBS Designator \#7.3.1.4.9, Westinghouse Hanford Company, Richland, Washington.

Kirkpatrick, K. L. and B. L. Oswald, 1995, Waste Specification System, WHC-EP-0846, UC-2020, Westinghouse Hanford Company, Richland, Washington.

Mercado, M. S., 1996, Safety Evaluation for Packaging for Onsite Transfer of 12 Ion Exchange Columns, WHC-SD-TP-SEP-047, Revision 0, Westinghouse Hanford Company, Richland, Washington.

WHC, 1995, Hazardous Material Packaging and Shipping, WHC-CM-2-14, Release 13, Westinghouse Hanford Company, Richland, Washington. 
WHC-SD-NEL-ER-004 Rev. 0

309 BUILDING

AdVANCED FUEL FACILITIES TRANSITION

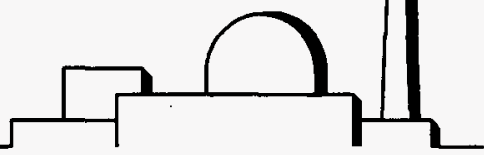

APPENDIX A - PROJECT PHOTOGRAPHS 


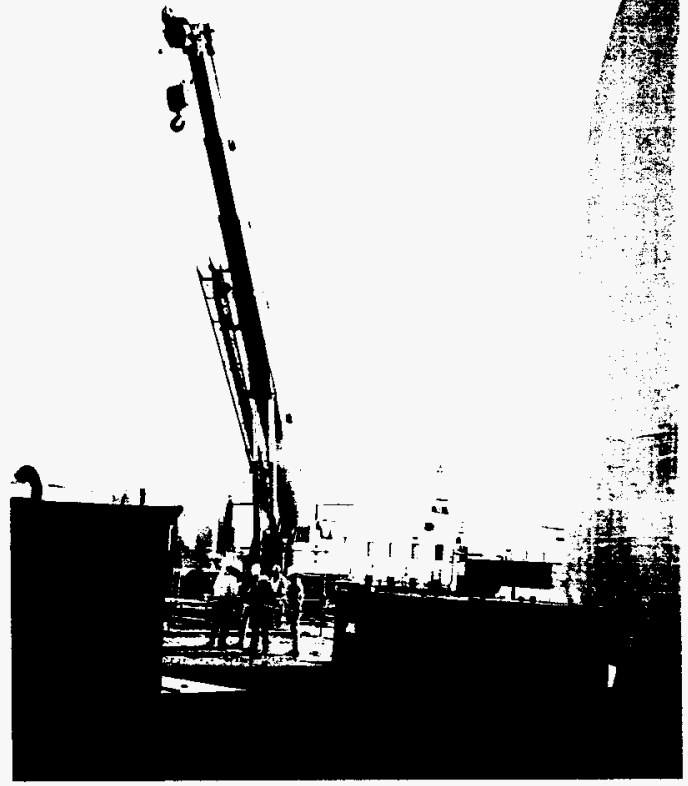

Figure A-1 Crane positioned to begin RLAIX vault deactivation. (96050172-19CN)

\section{BEST AVAILABLE COPY}

Figure A-2 Equipment staged to sample IX column liquids. (96050172-1CN)

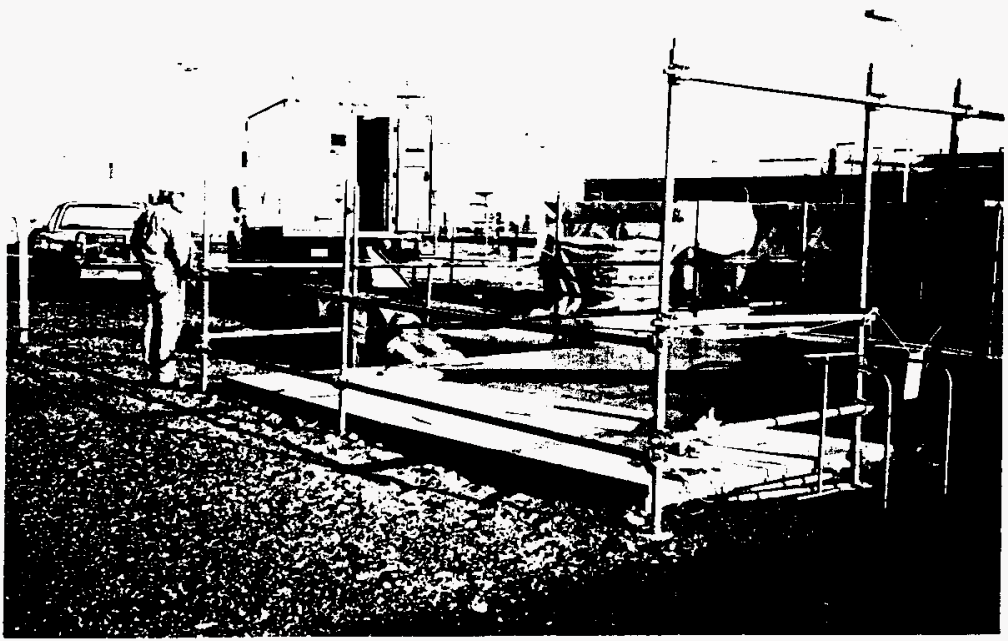




\section{WHC-SD-NEL-ER-004 Rev. 0}

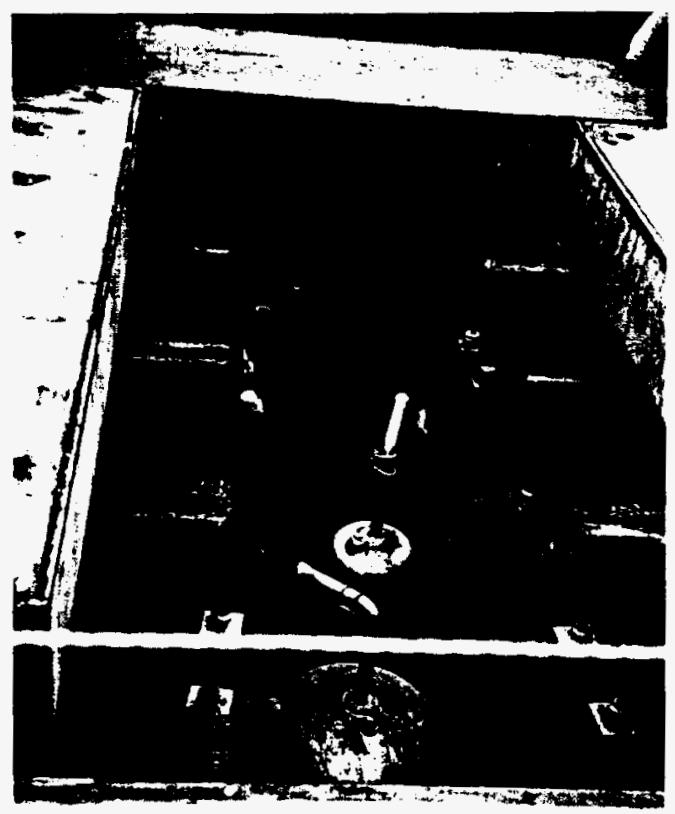

Figure A-3 lon exchange columns to be removed from RLAIX vault.

(96050172-56CN)

\section{BEST AVAILABLE COPY}

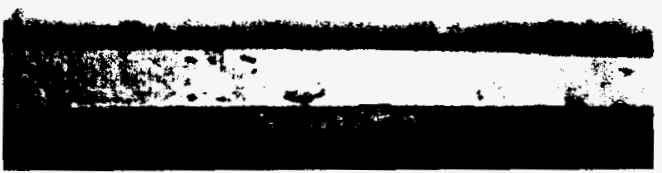

Figure A-4 Miscellaneous

debris and equipment to be removed from RLAIX vault.

(96050241-4)

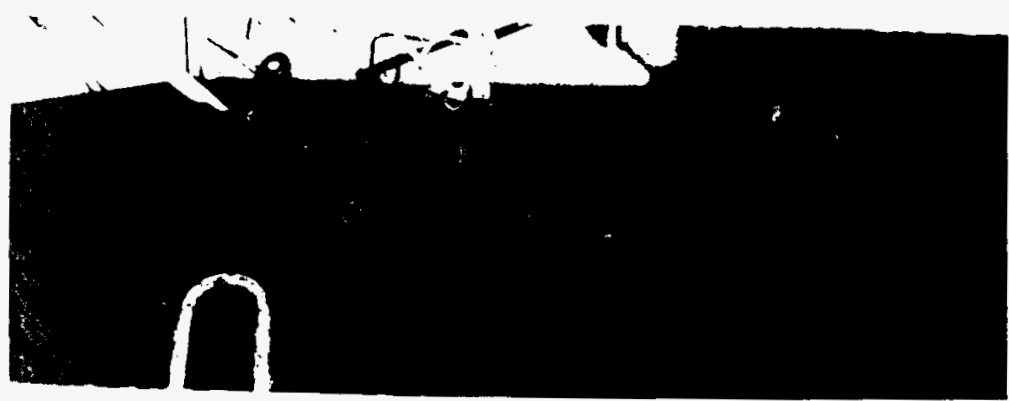


Figure A-5 Liquid pumped from $\mathrm{XX}$ columns by SML personnel. (96050241-23)

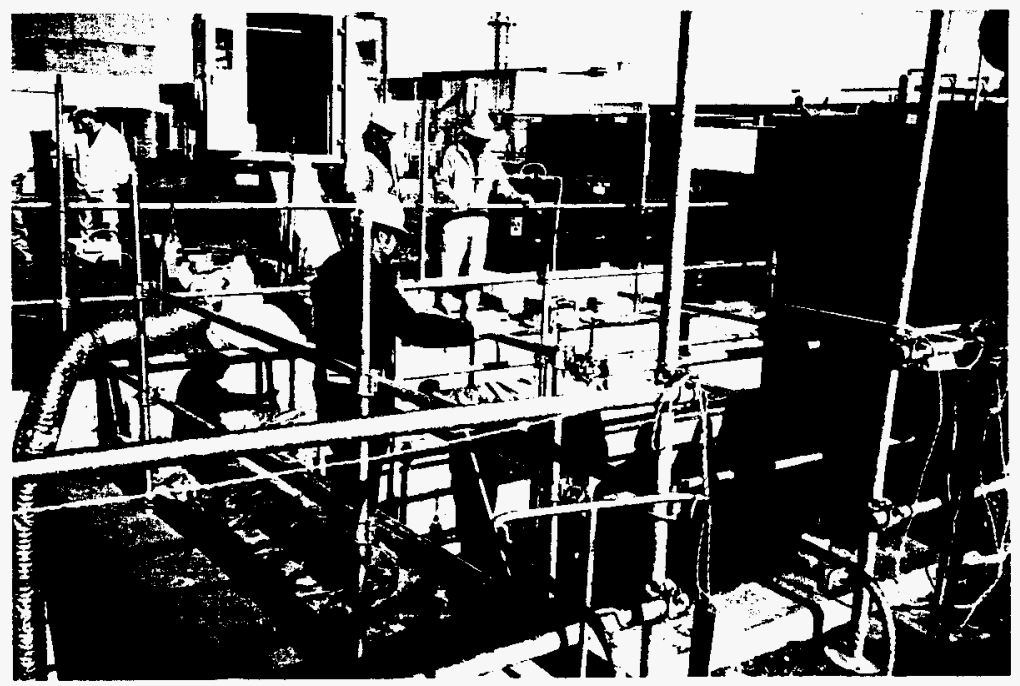

Figure A-6 Absorbent added to empty IX columns. (96050172-11CN)

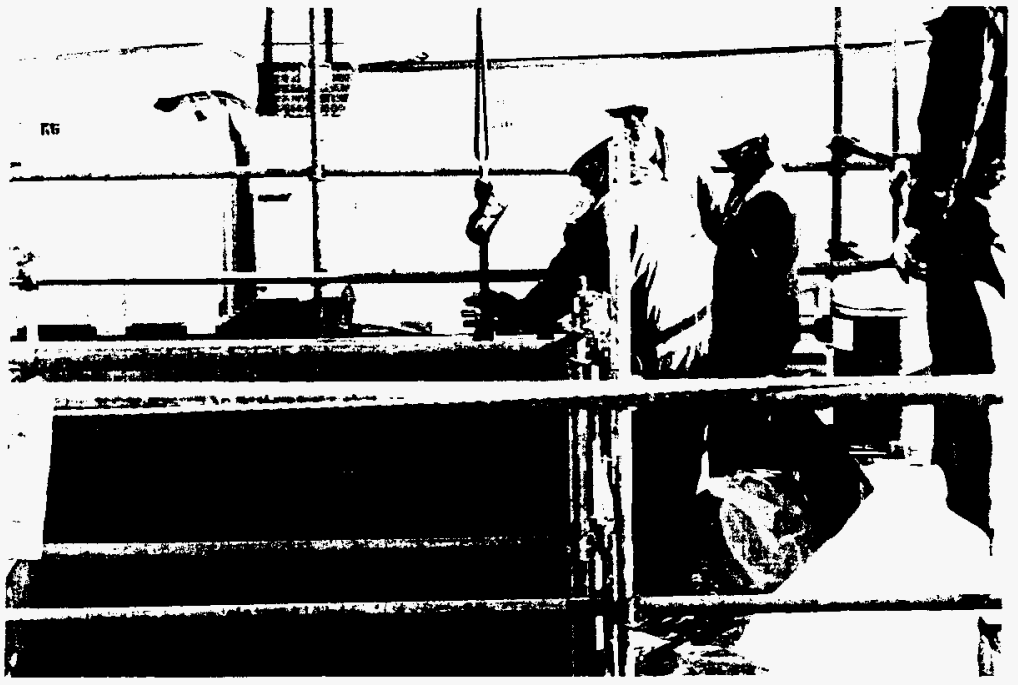


Figure A-7 Column removed from RLAIX vault. (96050243-29CN)

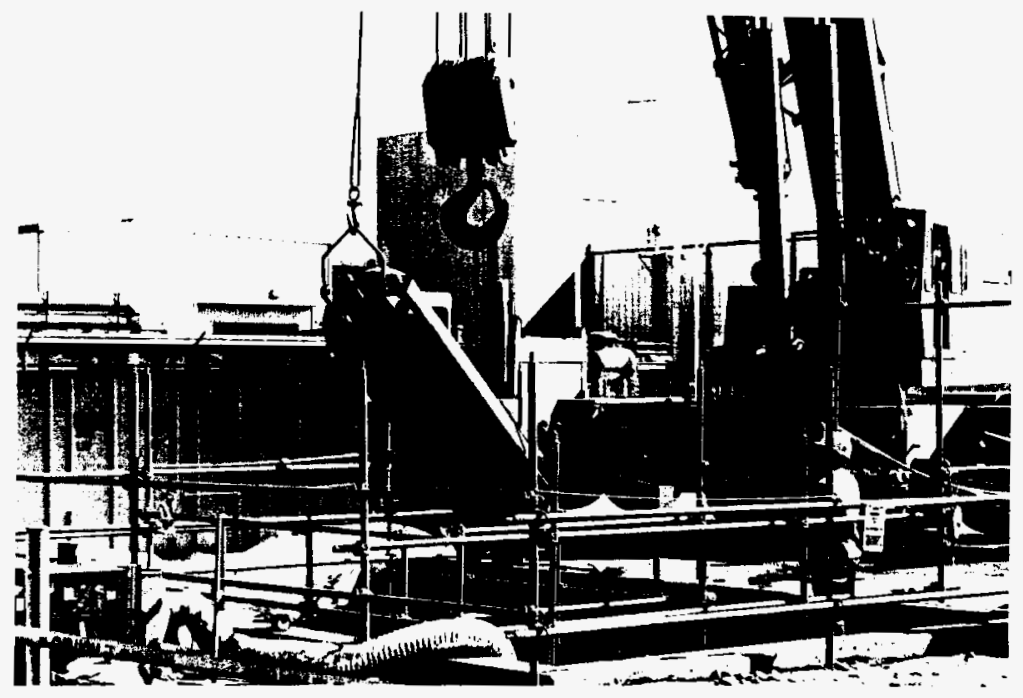

Figure A-8 Column positioned in waste container. (96050243-33CN)

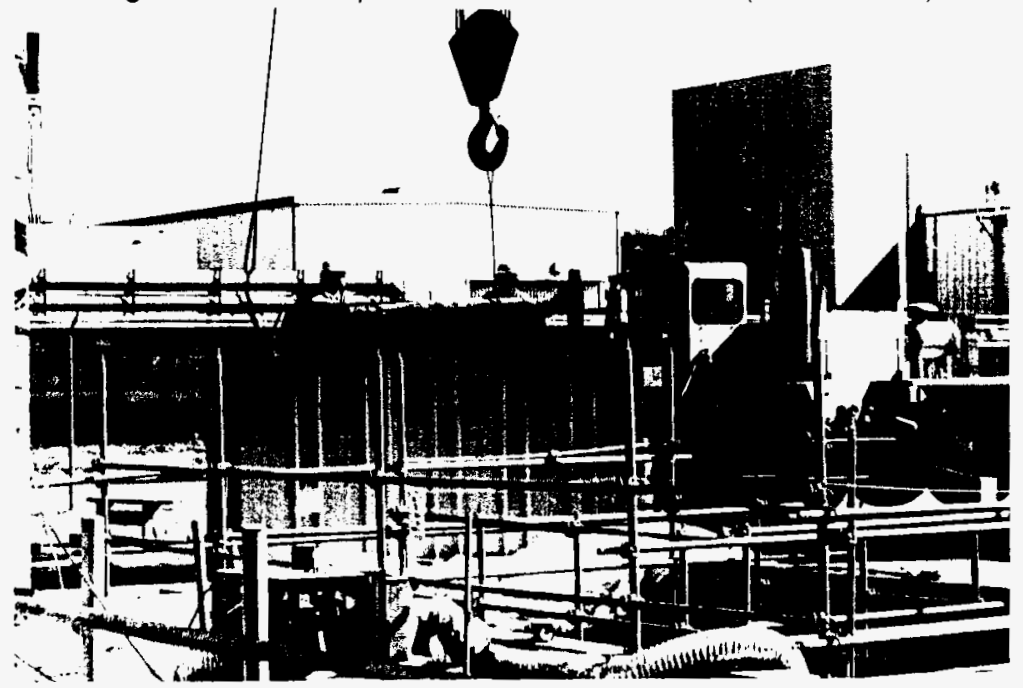



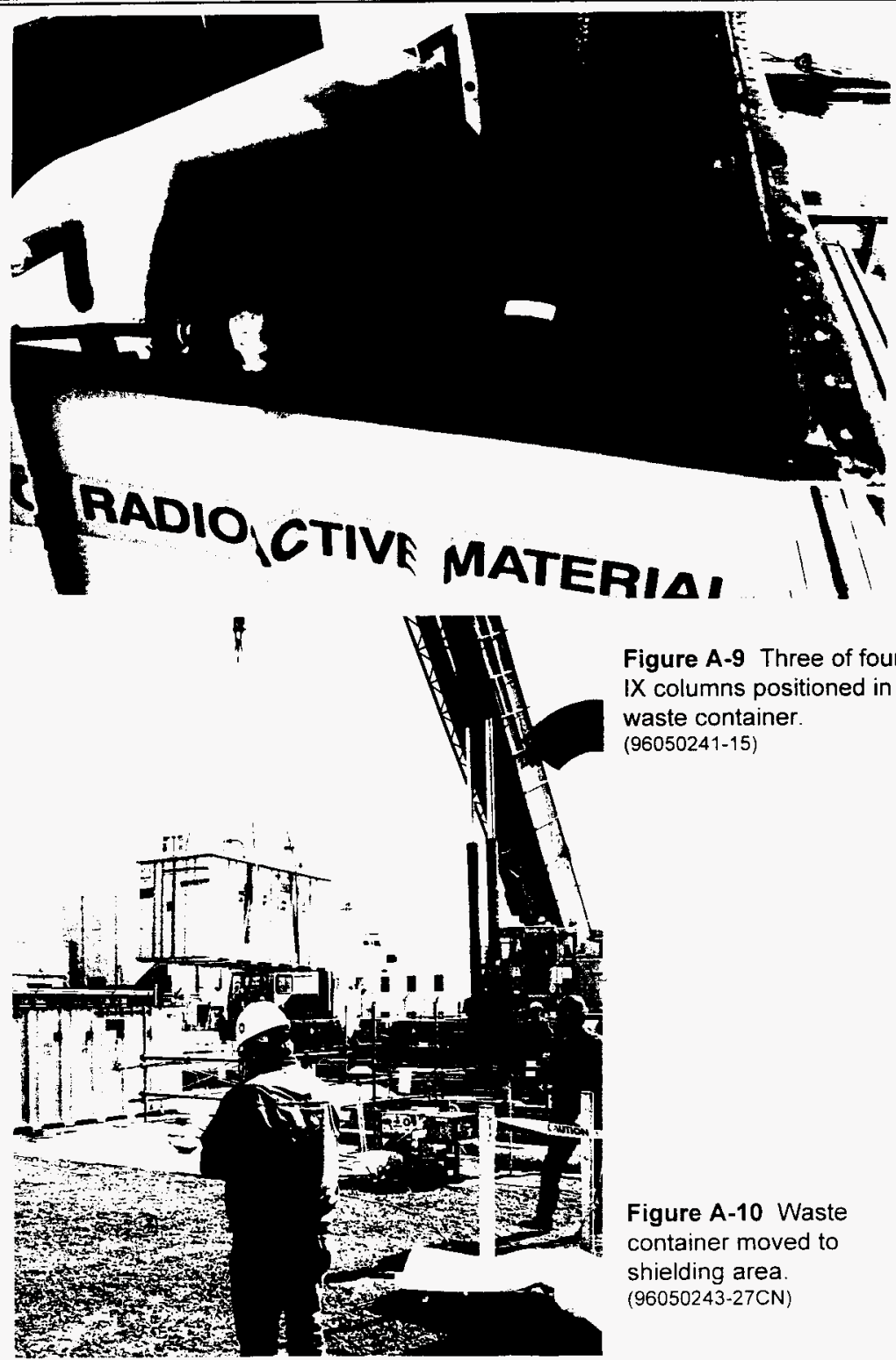

Figure A-9 Three of four IX columns positioned in waste container. (96050241-15)

Figure A-10 Waste container moved to shielding area. (96050243-27CN) 
Figure A-11 Columns void filled with grout. (96050318-14)

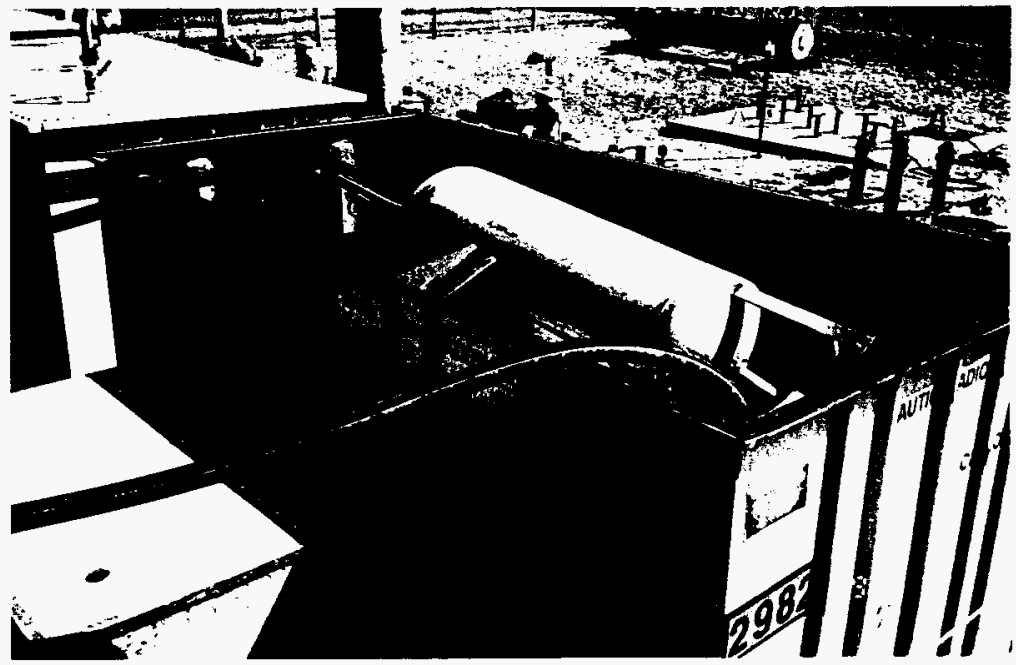

Figure A-12 Waste container stabilized with grout. (96050456-72CN)

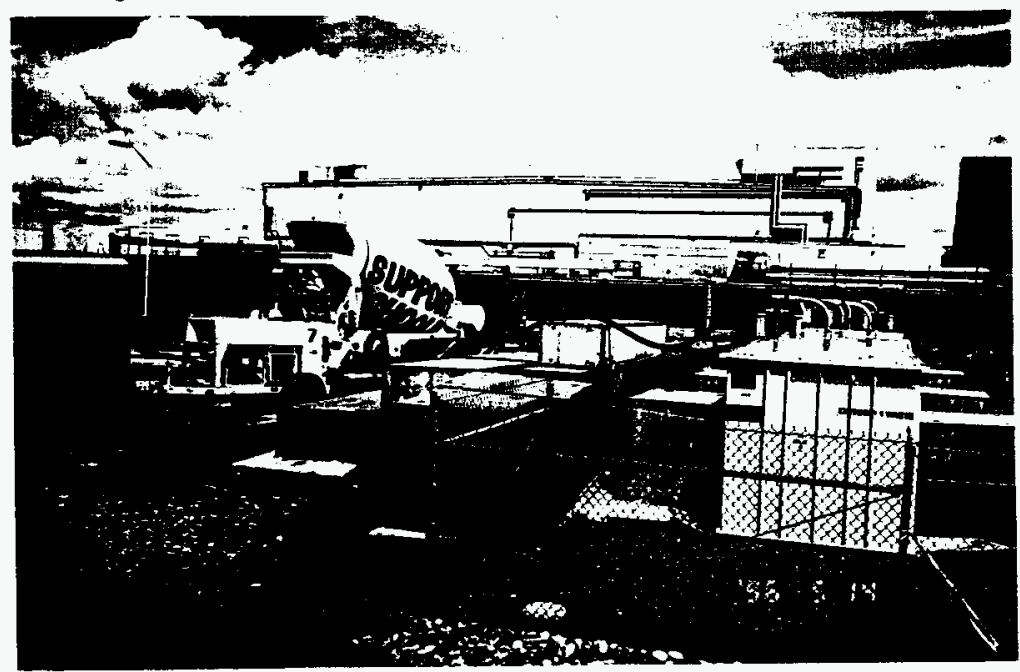


Figure A-13 Miscellaneous debris removed from RLAIX vault. (96050318-23)

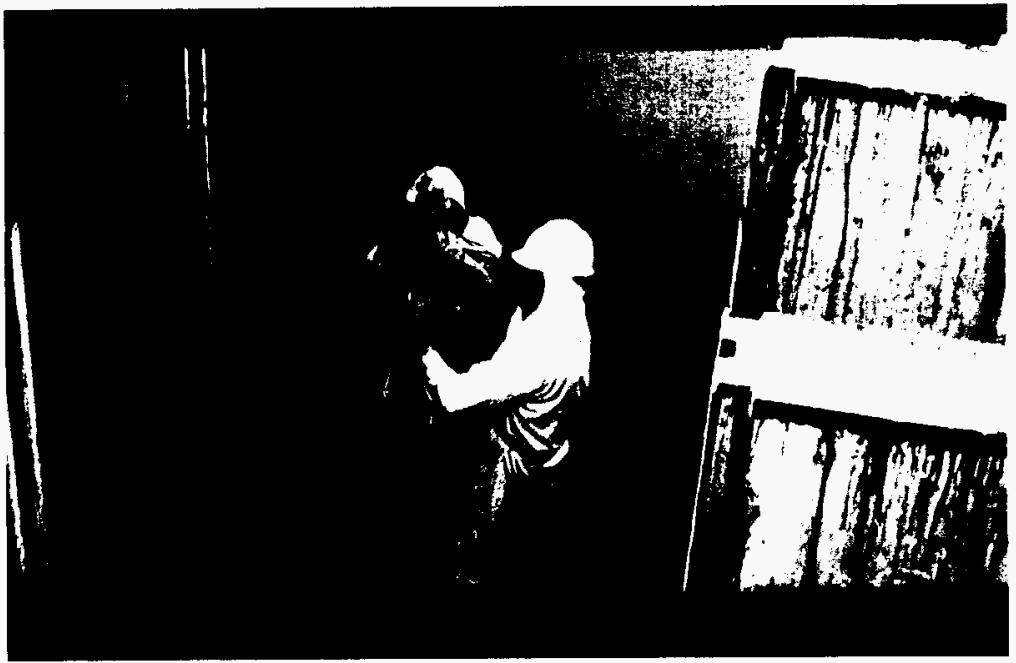

Figure A-14 RLAIX vault after removal of IX columns and debris. (96060178-38CN)

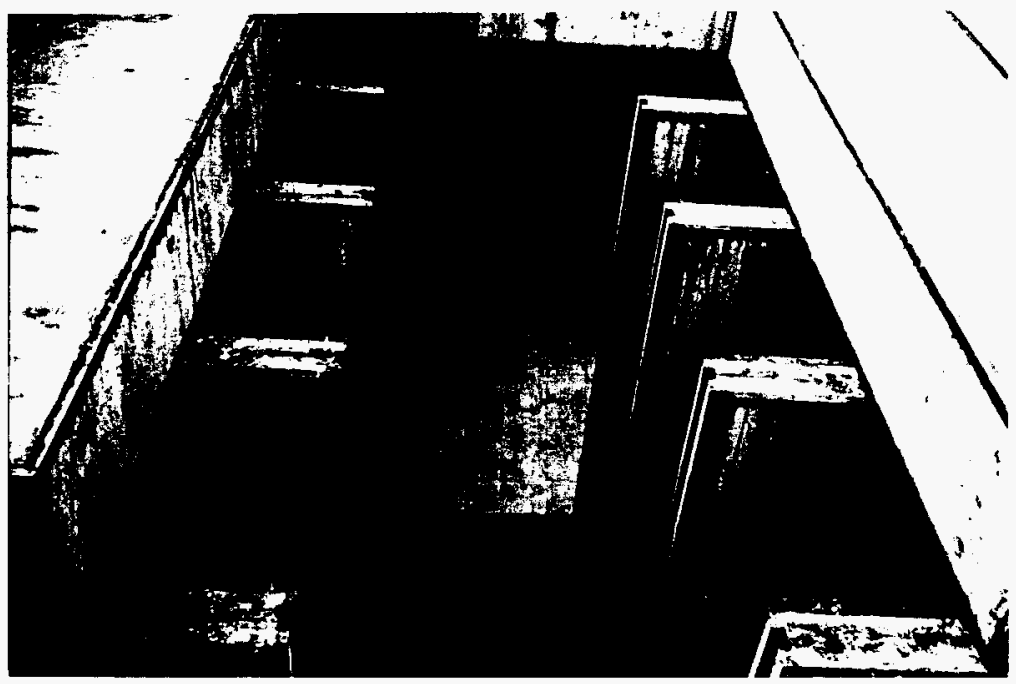


Figure A-15 Smearable contamination stabilized within RLAIX vault. (96060178-45CN)

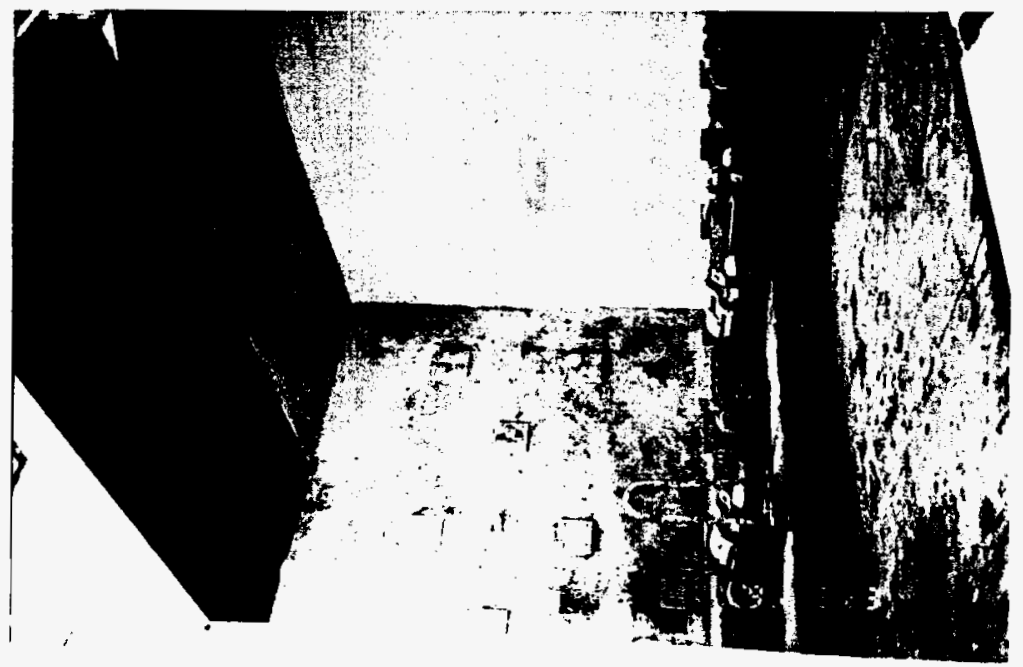

Figure A-16 Cover blocks and rain cover replaced on RLAIX vauit. (96060178-56CN)

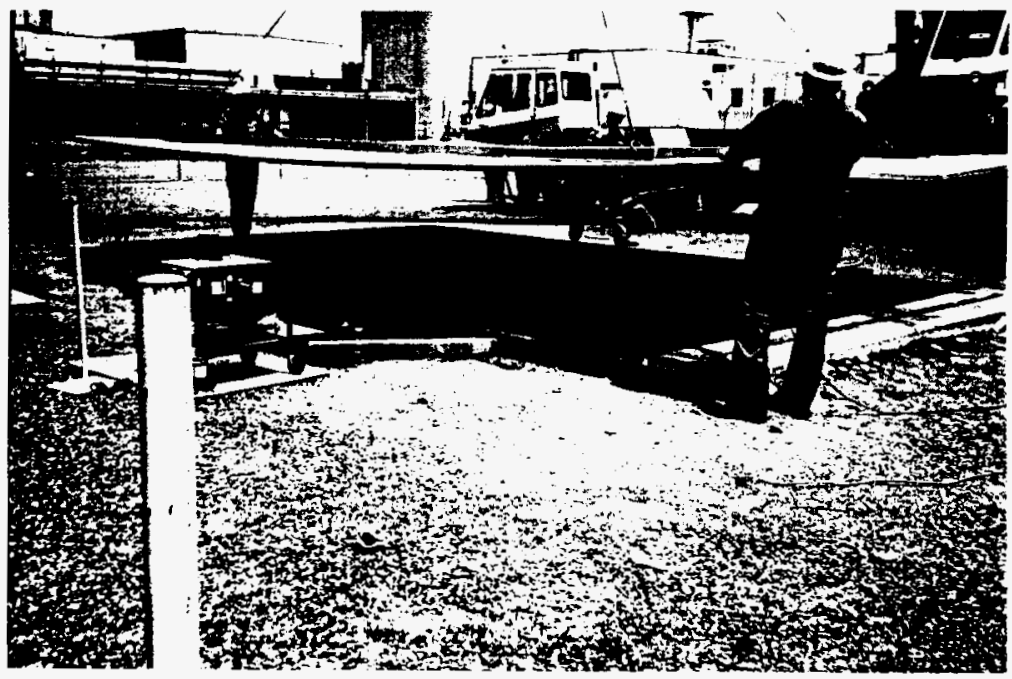



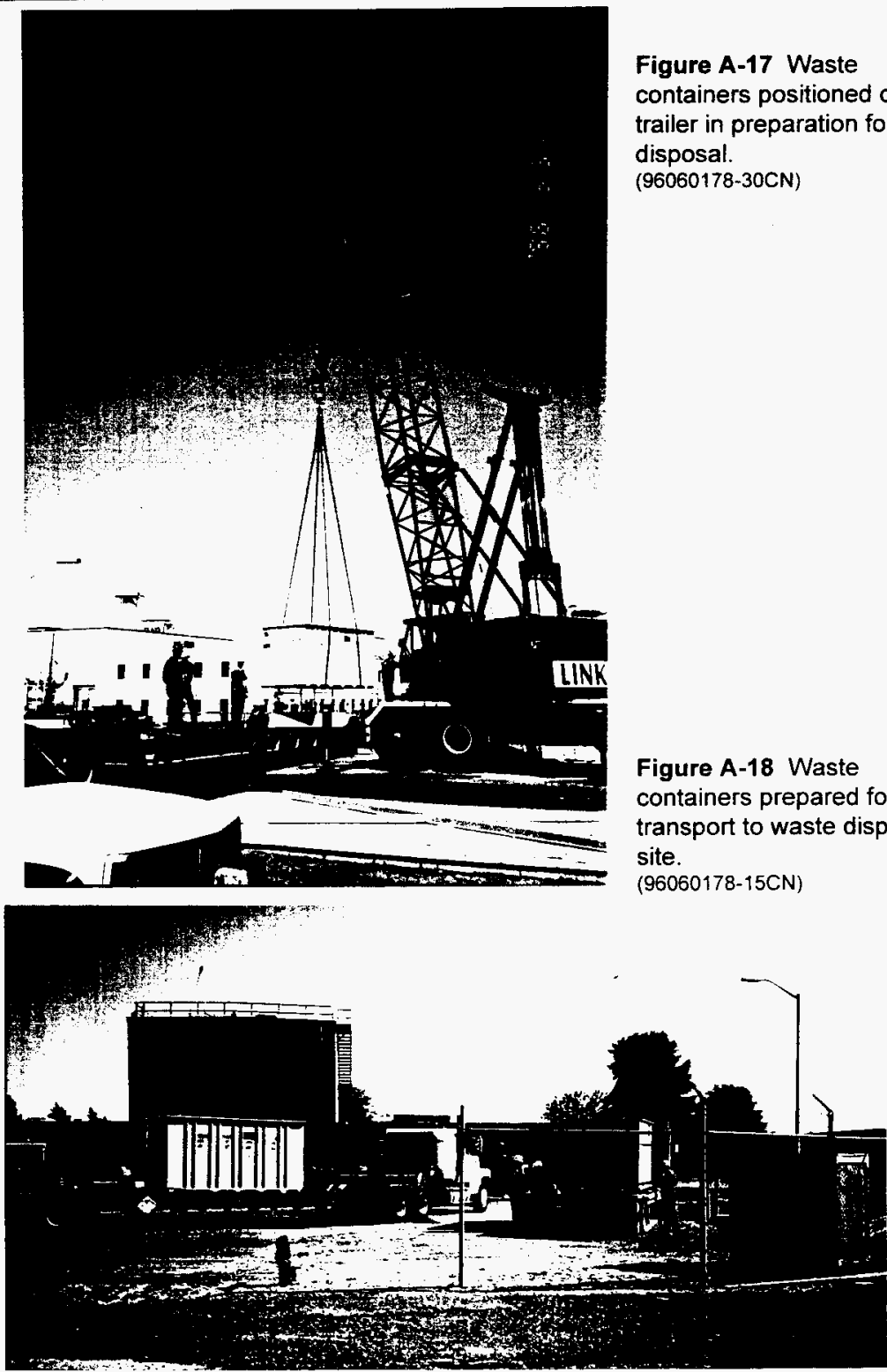

Figure A-17 Waste containers positioned on trailer in preparation for disposal.

(96060178-30CN)

Figure A-18 Waste containers prepared for transport to waste disposal site. (96060178-15CN) 
Page B - 1

WHC-SD-NEL-ER-004 Rev. 0

309 BUILDING

advanced fuel facilities transition

APPENDIX B - LIQUID SAMPLE RESULTS 
Battelle Pacific Northwest National Laboratory

Analytical Chemistry Laboratory

Radiochemistry Group - $325 \mathrm{Bldg}$.

JE Ham/FJ Carvo/BC Cornwell ED639l

Cognizant Scientist: 209/heevereof Date: $5 / 24 / 96$

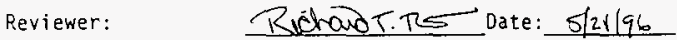

A $100 \mathrm{ml}$ of the sample was directly counted on a high efficiency germanium gama detector. Smaller aliquots were then dried for dual alpha/beta couning on a low background gas proportional counter, and analyzed for chloride and other cations by Ion Chromatography (IC), $\mathrm{PH}$, and RCRA metals by Inductively Coupled Plasma Mass Spectrometry (ICP-MS). Results are given below and on the attached report sheets.

\section{Measured Activities (pCi/ml)}

Analysis

Gross Alpha

Gross Beta

(as $90-\mathrm{S} r / 90-\mathrm{Y}$ )

Gamma Energy Analysis:

$$
60-\mathrm{CO}_{0}
$$

$137-C s$

241-Am

$\mathrm{pH}$

$\frac{\text { RLAX }-1}{96-4330}$
$5.41 E+0 \quad 6 \%$
$6.16 E+1 \quad 4 \%$

$6.16 E+1 \quad 4 \%$

$6 \%$

$<2.4 \mathrm{E}-2$

$105 \%$

3. $3 \mathrm{E}-2 \pm 35 \%$

$89 \%$

$\frac{\text { Quality Control }}{\text { Blank Standard Spike }}$

$<2.4 \mathrm{E}-2 \quad 105 \% \quad 123 \%$

$\begin{array}{rr}3.26 E-1 & 8 \% \\ 7.17 E+1 & 4 \% \\ 2.68 E+0 & 10 \%\end{array}$

10.8 


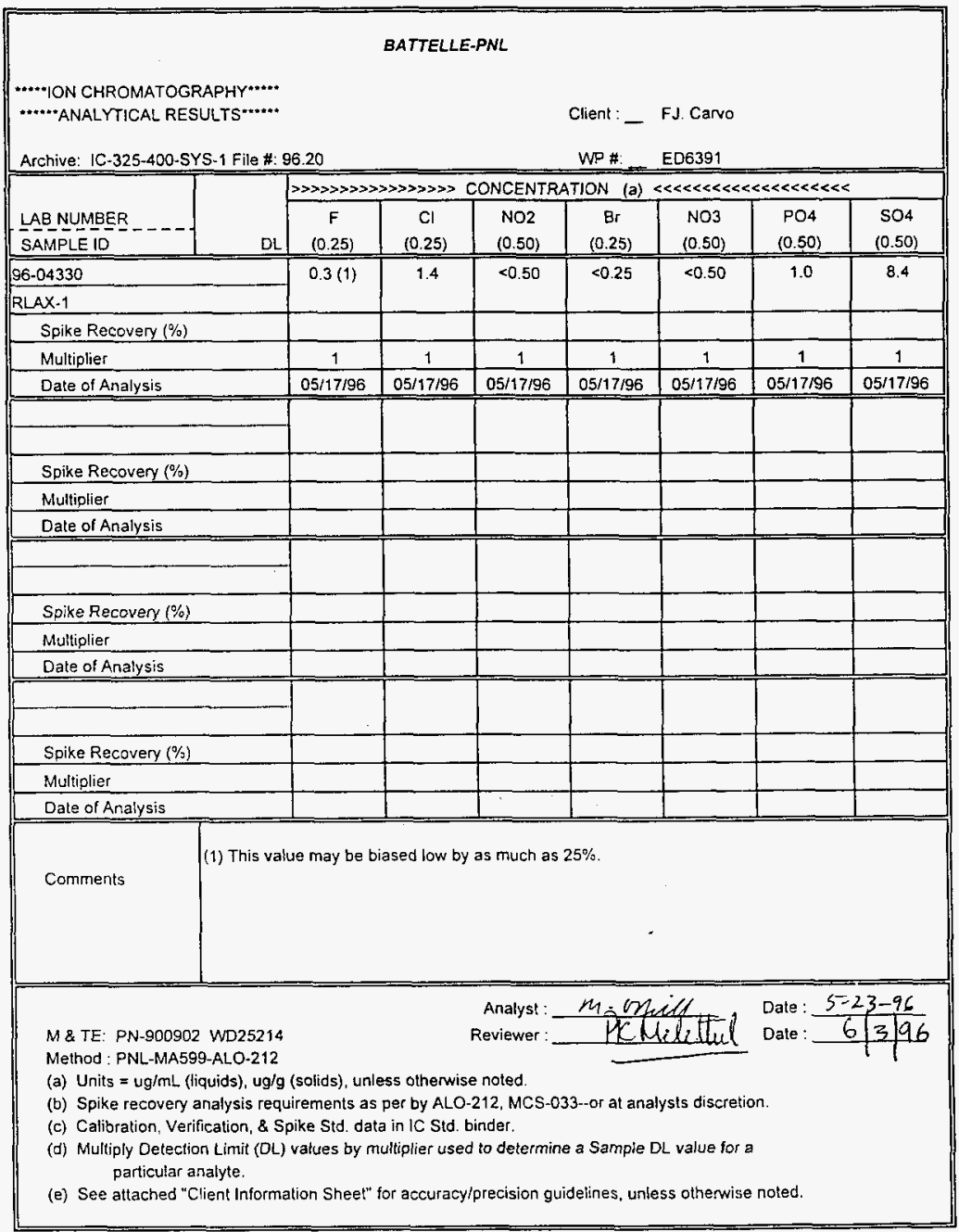




\section{Battelle PNNLACL/norganic Analysis Group: ICPAES Analytical Report}

$\begin{array}{ll}\text { WO/Project: } & \text { ED6391/20063 } \\ \text { Client: } & \text { FJ Carvo } \\ \text { Impact Level: } & \text { II }\end{array}$

ACL Nmbr(s): $96-004330$

Client ID: "RLAX-1"

ASR Nmbr 3070

Total Samples: 1

Procedure: PNNL-ALO-211, "Determination of Elements by Inductively Coupled Argon Plasma Atomic Emission Spectrometry" (ICP-AES).

Analyst: DR Sanders

Analysis Date (Filename): 05/24/96 (A0122)

See ALO System File: "ICP-325-405-1" for traceability to Calibration, Quality Control, Verification, and Raw Data.

M\&TE Number: ICPAES instrument - WB73520

Mettler AT400 Balance -- Ser.No. 360-06-01-029

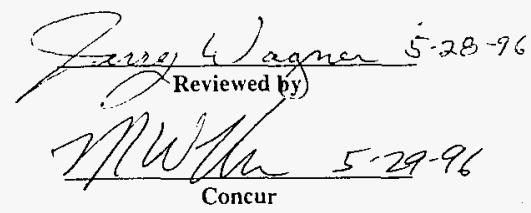




\section{Battelle PNNL/ACLInorganic Analysis Group: ICPAES Analytical Report}

One radioactive liquid sample was processed, in duplicate, by 325 SRPL using PNL-ALO128 acid extraction procedure. Twenty $\mathrm{mL}$ aliquots were treated and diluted to a final volume of $25 \mathrm{~mL}$. The sample, before processing, appeared to be a brown stained liquid with visible sediment present. After processing the sample appeared clear and free of sediment. No additional dilution during ICPAES analysis was required.

Sample duplicates, serial dilution, matrix spike, post-digestion spikes and quality control check standards were within control limits except for Silver in the matrix spike. Recovery of Silver in the blank-spike was approximately $30 \%$. Control limit is 75 to $125 \%$. The presence of $\mathrm{HCl}$ used to prepare the sample is known to cause low recovery in spiked samples. Several reports in the literature have confirmed this observation.

None of the TCLP analytes exceed regulatory limits for the analytes measured in the sample ( $\mathrm{Ag}, \mathrm{As}, \mathrm{Ba}, \mathrm{Cd}, \mathrm{Cr}, \mathrm{Pb}$, and $\mathrm{Se}$ ). $\mathrm{Ag}$ was below detection limit even when adjusted for apparent low spike-recovery (e.g. $0.020 \mu \mathrm{g} / \mathrm{mL} / 0.030=0.067 \mu \mathrm{g} / \mathrm{mL}$ ). Regulatory limit for $\mathrm{Ag}$ in liquids is $5 \mu \mathrm{g} / \mathrm{mL}$.

Please see the attached "ICPAES Data Report" for measurement results, detection limits, and etc.

Note, bracketed values listed in the attached data report are within ten times instrument detection limit. Those measurement values have a potential uncertainty much greater than $15 \%$. 


\section{Battelle PNNL/ACL/Inorganic Analysis Group: ICPAES Analytical Report}

Comments:

1) "Final Results" have been corrected for all laboratory dilution performed on the sample during processing and analysis.

2) Detection limits (DL) shown are for acidified water. Detection limits for other matrices may be determined if requested.

3) Routine precision and bias is typically $\pm 15 \%$ or better for samples in dilute, acidified water (eg. $2 \% \mathrm{v} / \mathrm{v} \mathrm{HNO}_{3}$ or less) at analyte concentrations greater than ten times detection limit up to the upper calibration level. This also presumes that the total dissolved solids concentration in the sample is less than $5000 \mu \mathrm{g} / \mathrm{mL}(0.5$ per cent by weight).

4) Absolute precision, bias and detection limits may be determined on each sample if required by the client.

5) The maximum number of significant figures for all ICP measurements is 2.

6) To convert "WT\%" to "mg/Kg" or " $\mu \mathrm{g} / \mathrm{g}$ ", multiply concentration value by 10,000 .

7) To convert "mg/Kg" or " $\mu g / g$ " to "WT\%", divide concentration value by 10,000 . 
Battelle PNLACL/Inorganic Analysis Group: ICPAES Data Report

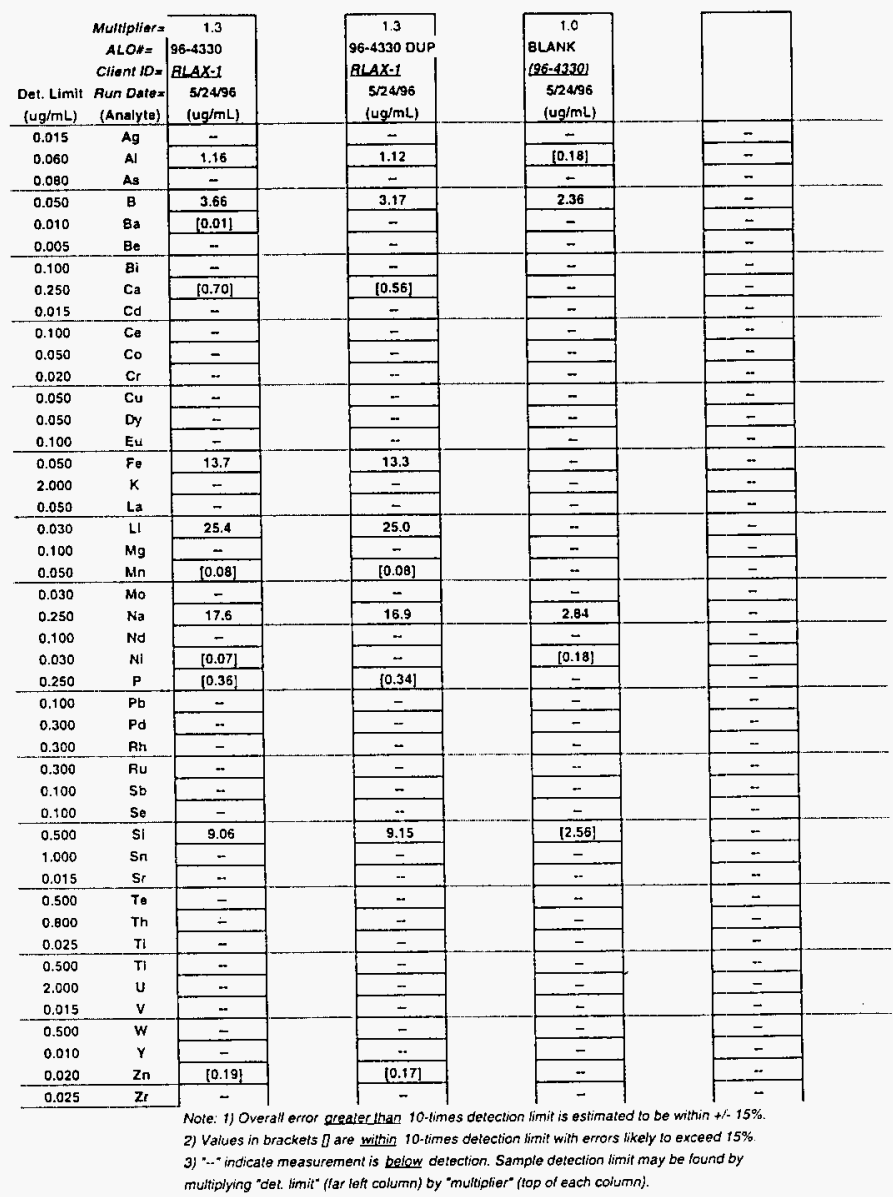




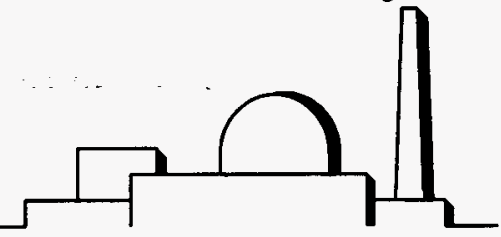

\section{APPENDIX C - RADIOLOGICAL SURVEY REPORTS}

\begin{tabular}{|c|c|c|c|}
\hline DATE & $\begin{array}{l}\text { RADIOLOGICAL } \\
\text { SURVEY REPORT \# }\end{array}$ & CODE & PAGE \# \\
\hline $5 / 1 / 96$ & 234284 & Vault & $\mathrm{C}-2$ \\
\hline $5 / 2 / 96$ & 234287 & Vault & $\mathrm{C}-6$ \\
\hline $5 / 3 / 96$ & 234292 & Vault & C-10 \\
\hline $5 / 6 / 96$ & 234296 & Vault & C-13 \\
\hline $5 / 7 / 96$ & 234299 & Vault & $C-16$ \\
\hline $5 / 8 / 96$ & 234302 & Vault & C-18 \\
\hline $5 / 9 / 96$ & 234309 & Vault & C-25 \\
\hline $5 / 9 / 96$ & 234313 & Vault & C-30 \\
\hline $5 / 13 / 96$ & 234315 & Vault & C-32 \\
\hline $5 / 13 / 96$ & 234320 & Vault & C-35 \\
\hline $5 / 14 / 96$ & 234322 & Vault & C-37 \\
\hline $5 / 14 / 96$ & 234327 & Tank Farm. & C-41 \\
\hline $5 / 15 / 96$ & 234328 & Tank Farm & C-43 \\
\hline $5 / 16 / 96$ & 234333 & Tank Farm & $C-46$ \\
\hline $5 / 22 / 96$ & 234345 & Containment & $C-48$ \\
\hline $5 / 23 / 96$ & 234349 & Tank Farm & C-50 \\
\hline $5 / 29 / 96$ & 234351 & Tank Farm & C-52 \\
\hline $5 / 30 / 96$ & 234355 & Tank Farm & C.57 \\
\hline
\end{tabular}




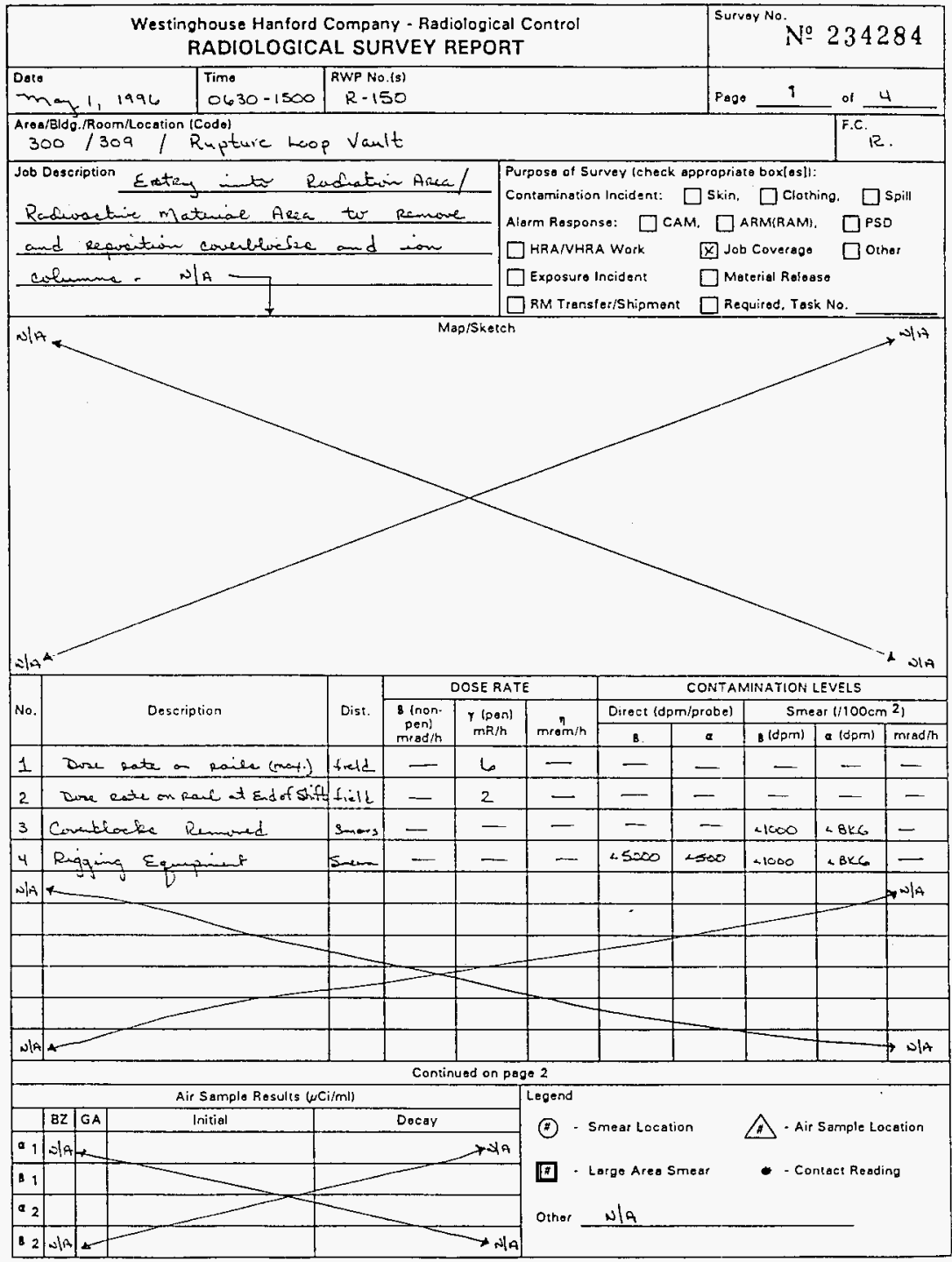




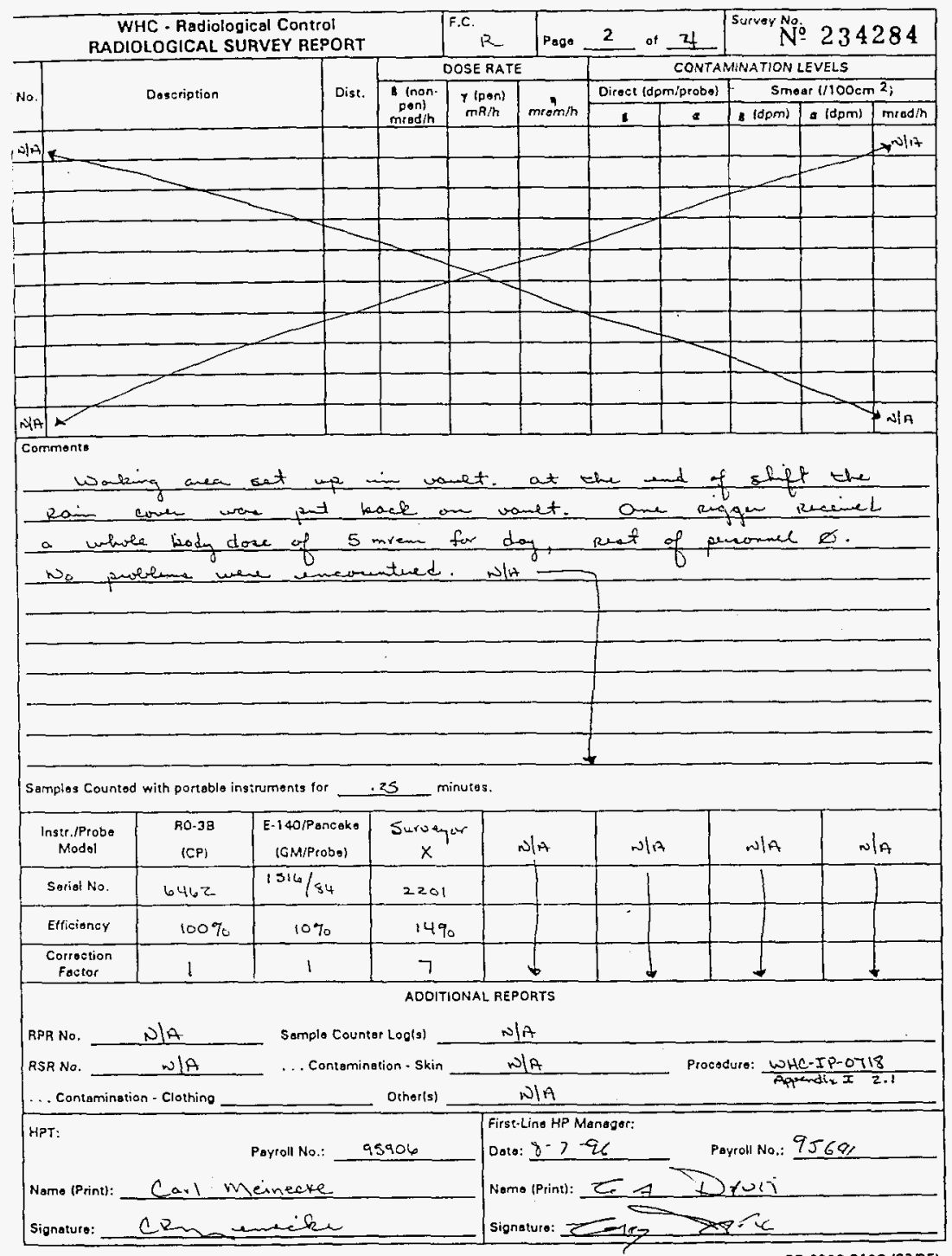




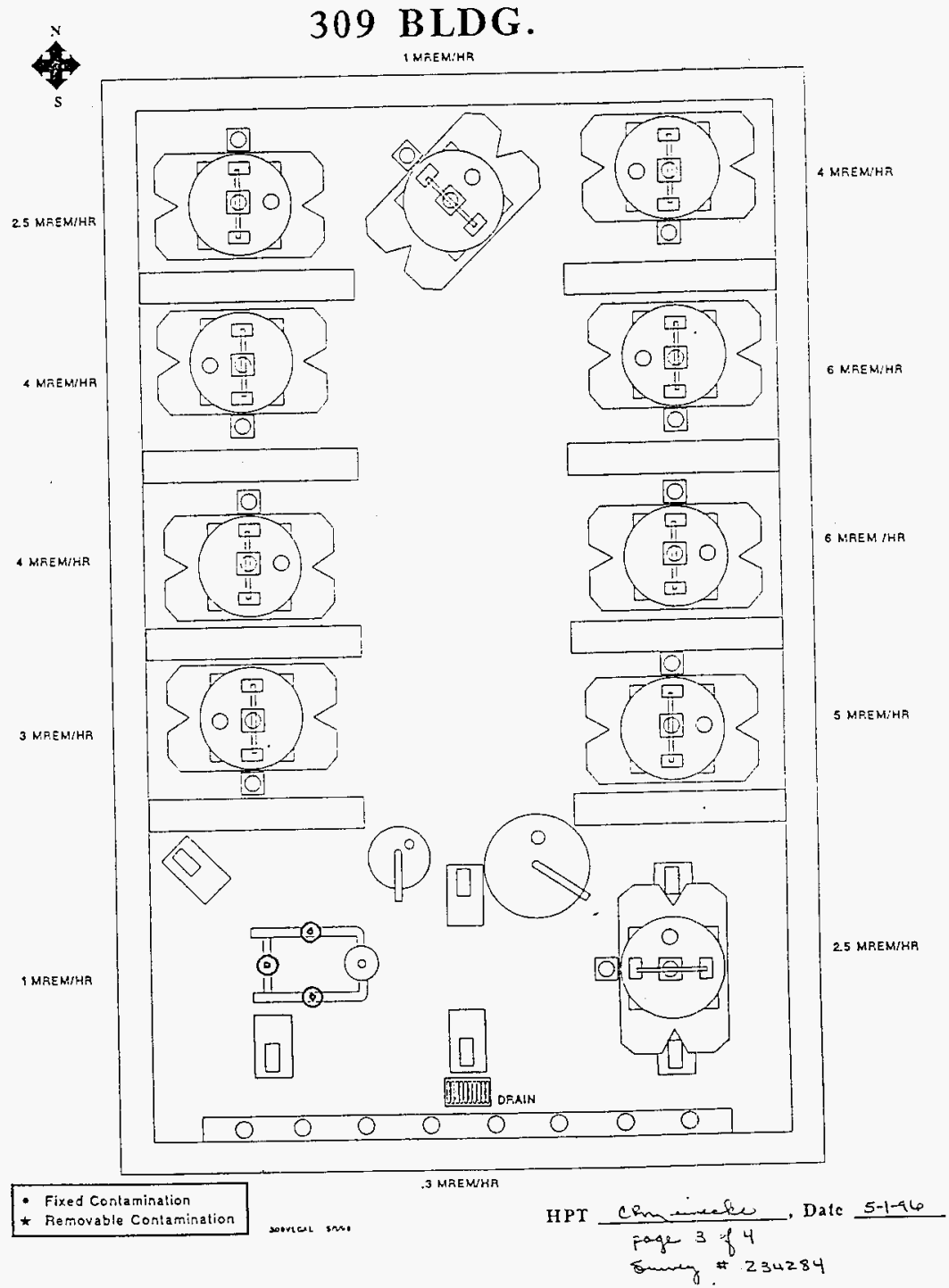




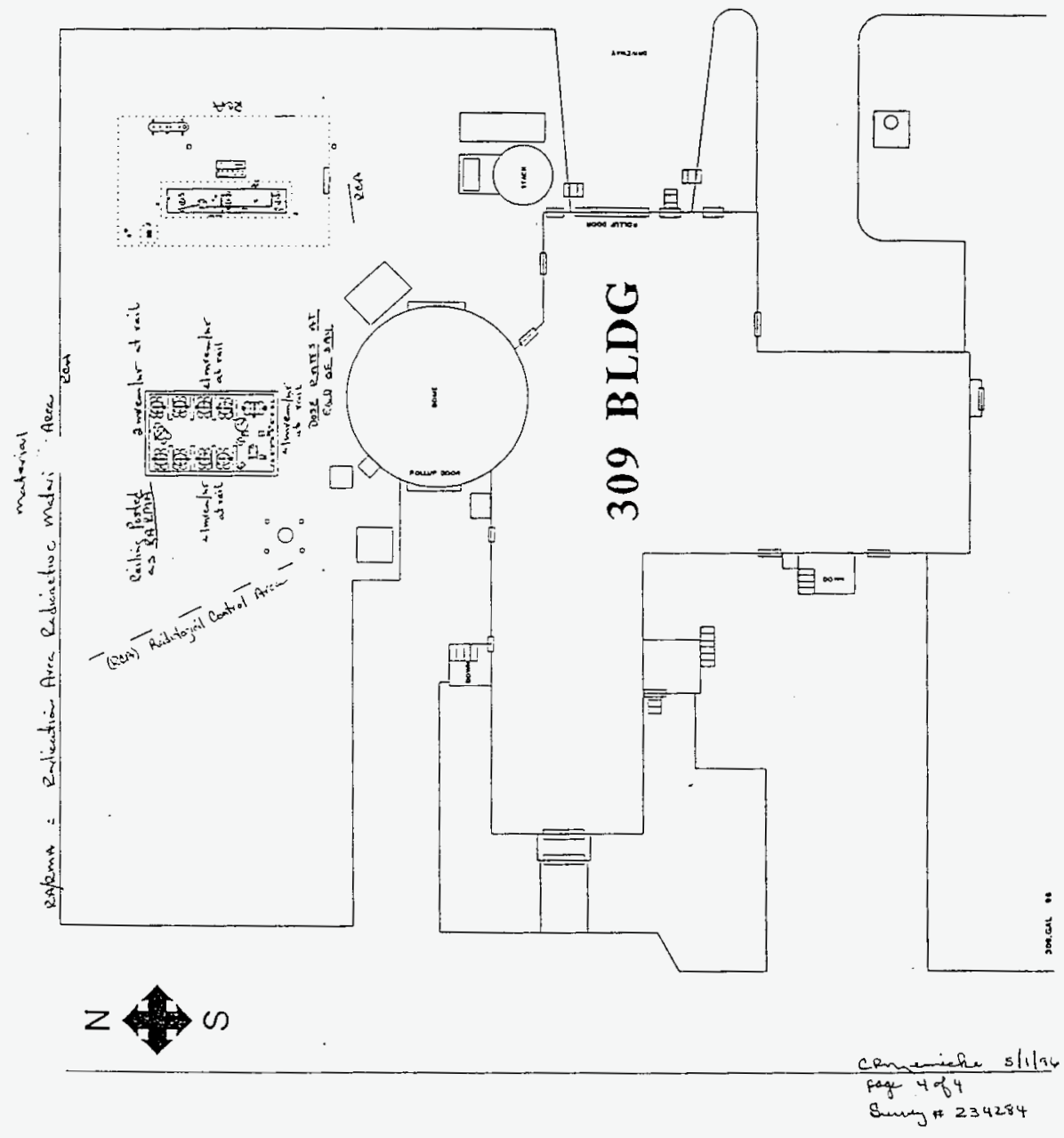




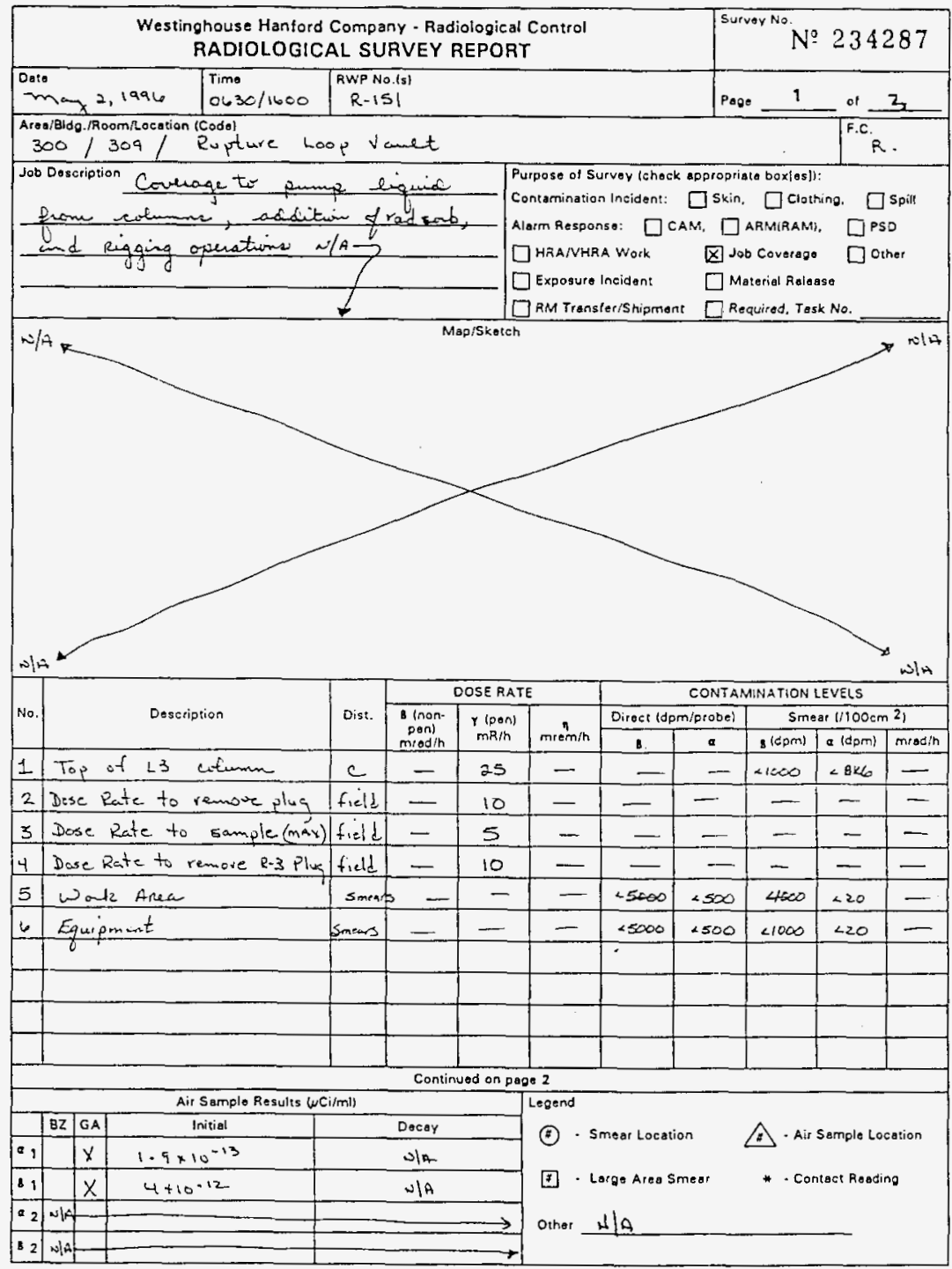




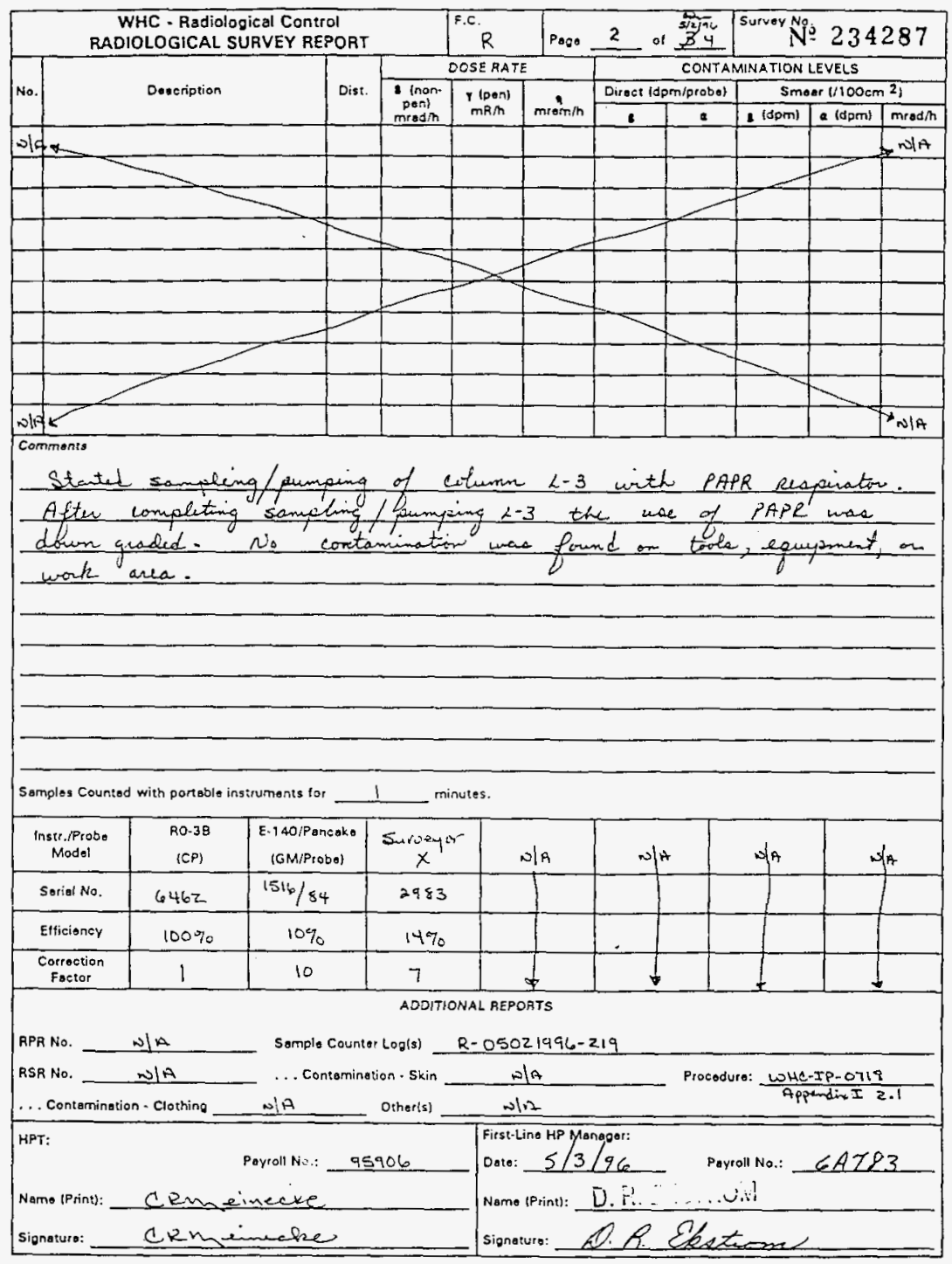




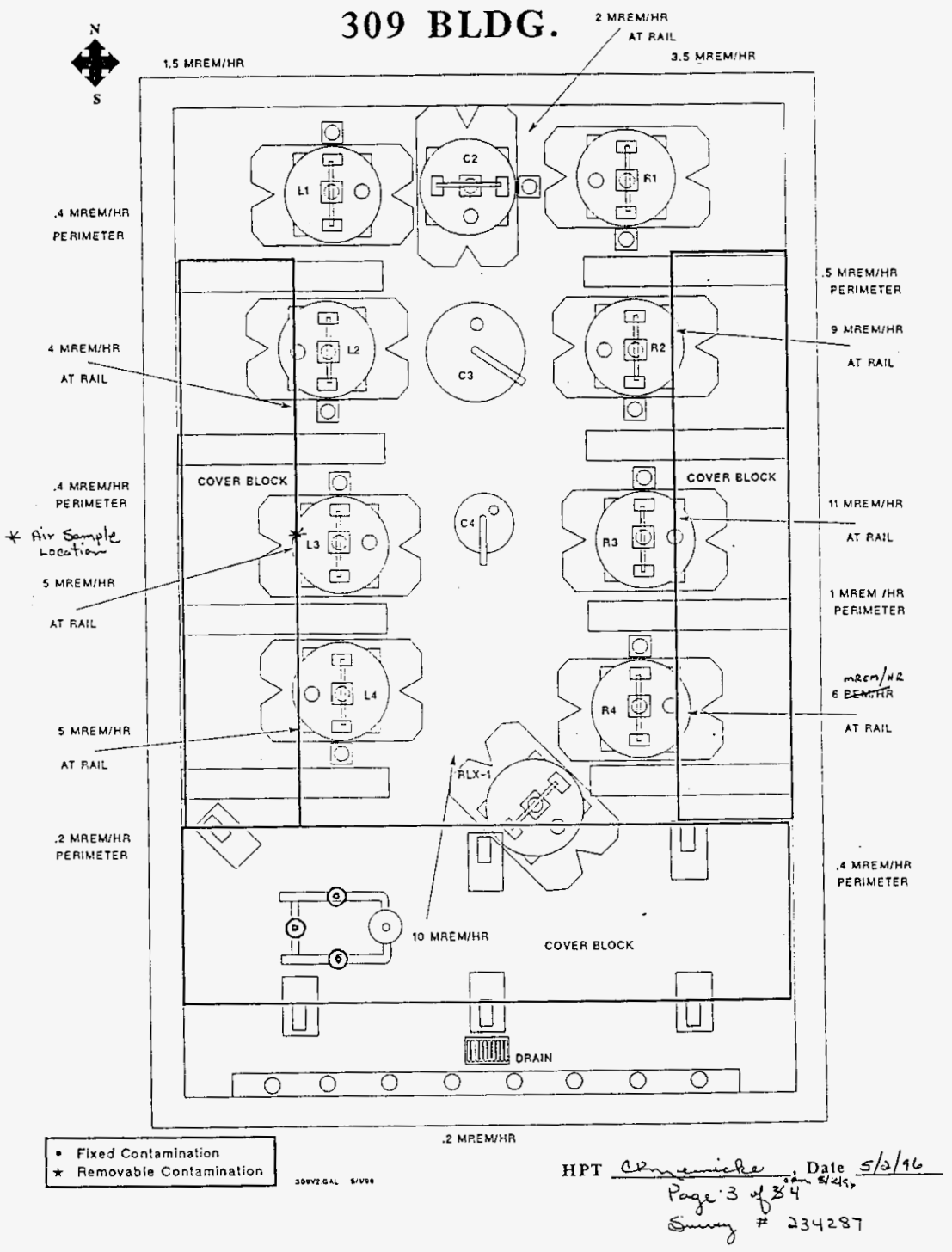


Page C - 9

WHC-SD-NEL-ER-004 Rev. 0

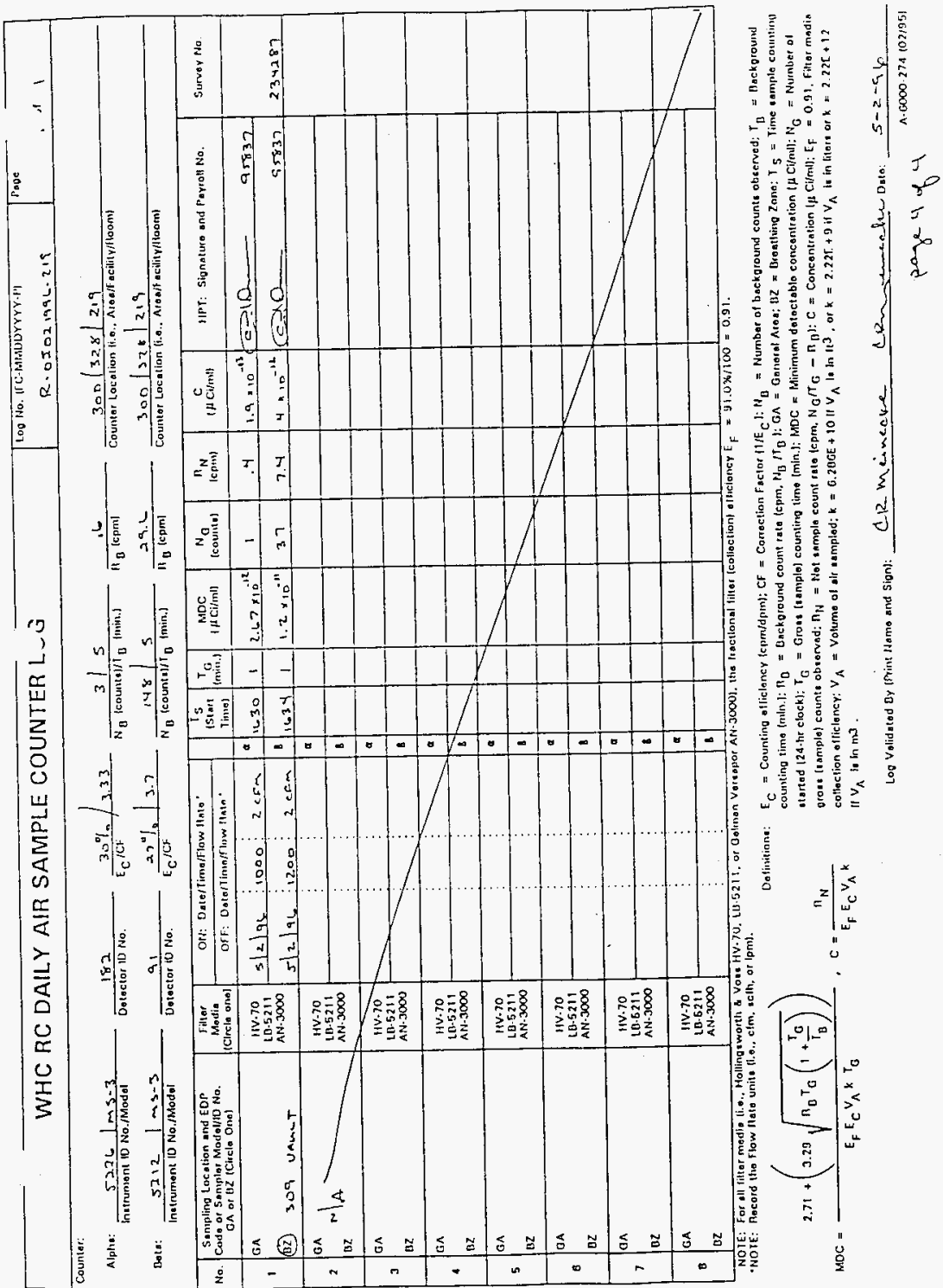




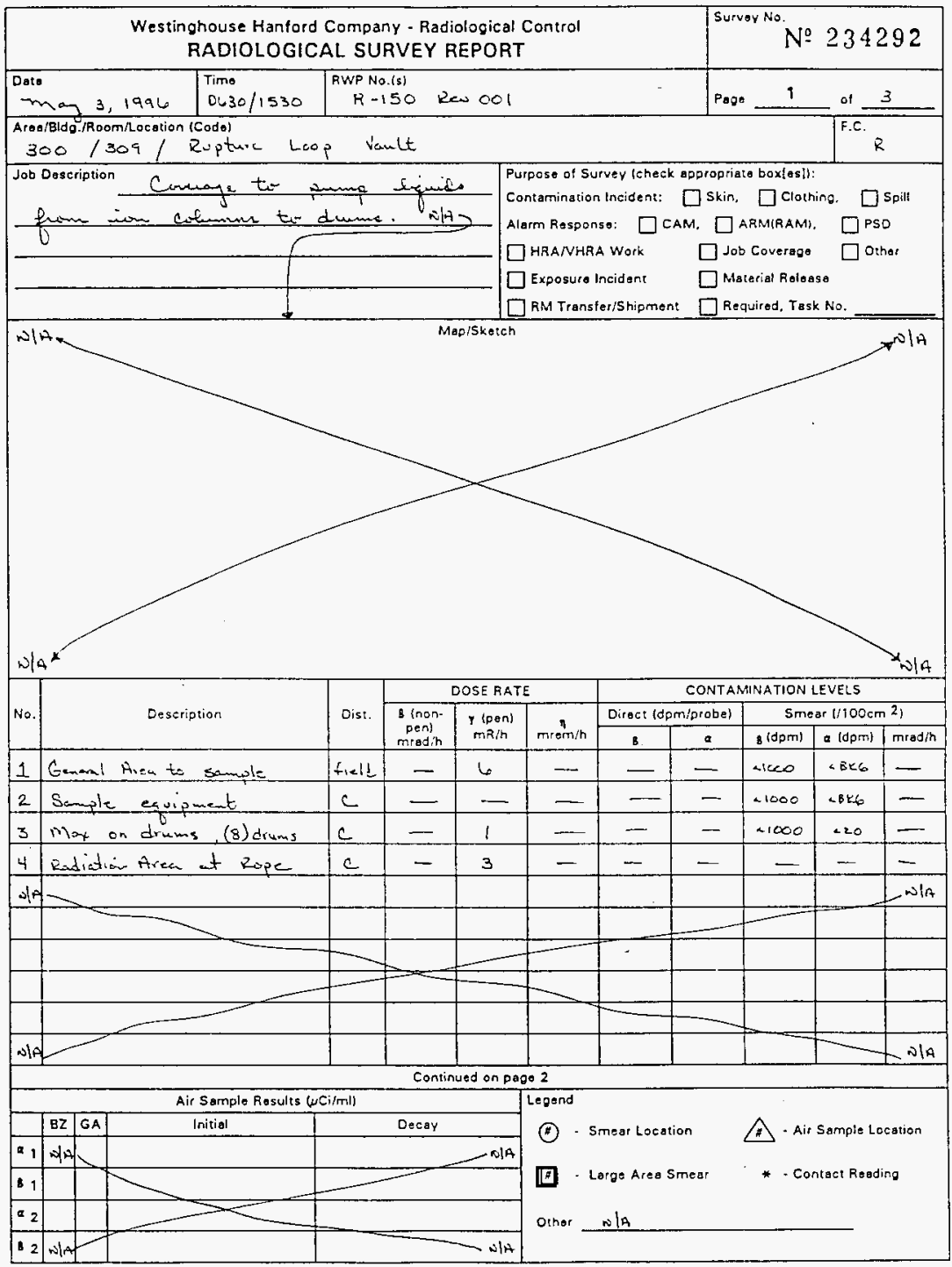

BD-6000.010 (03/95) 


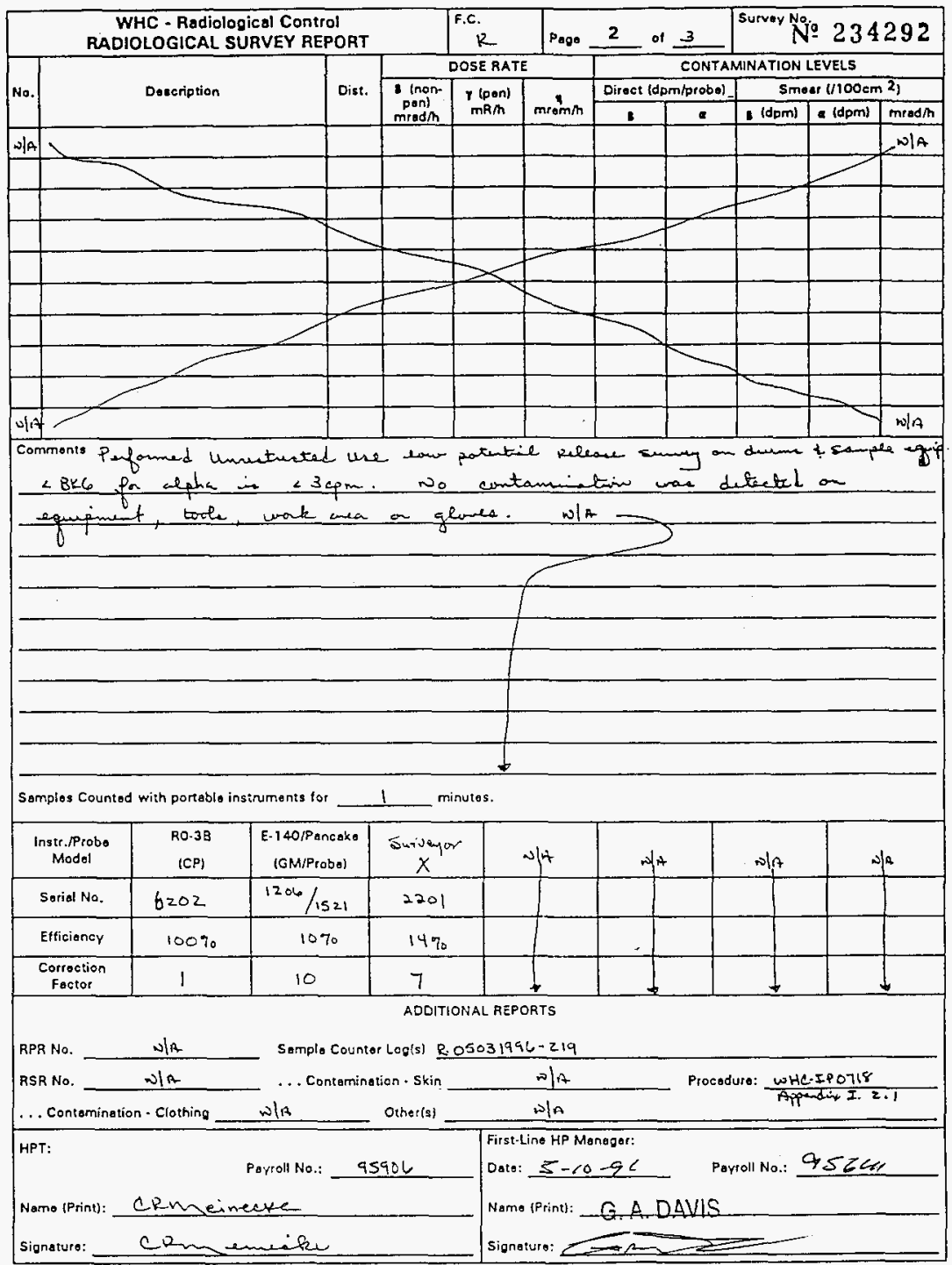




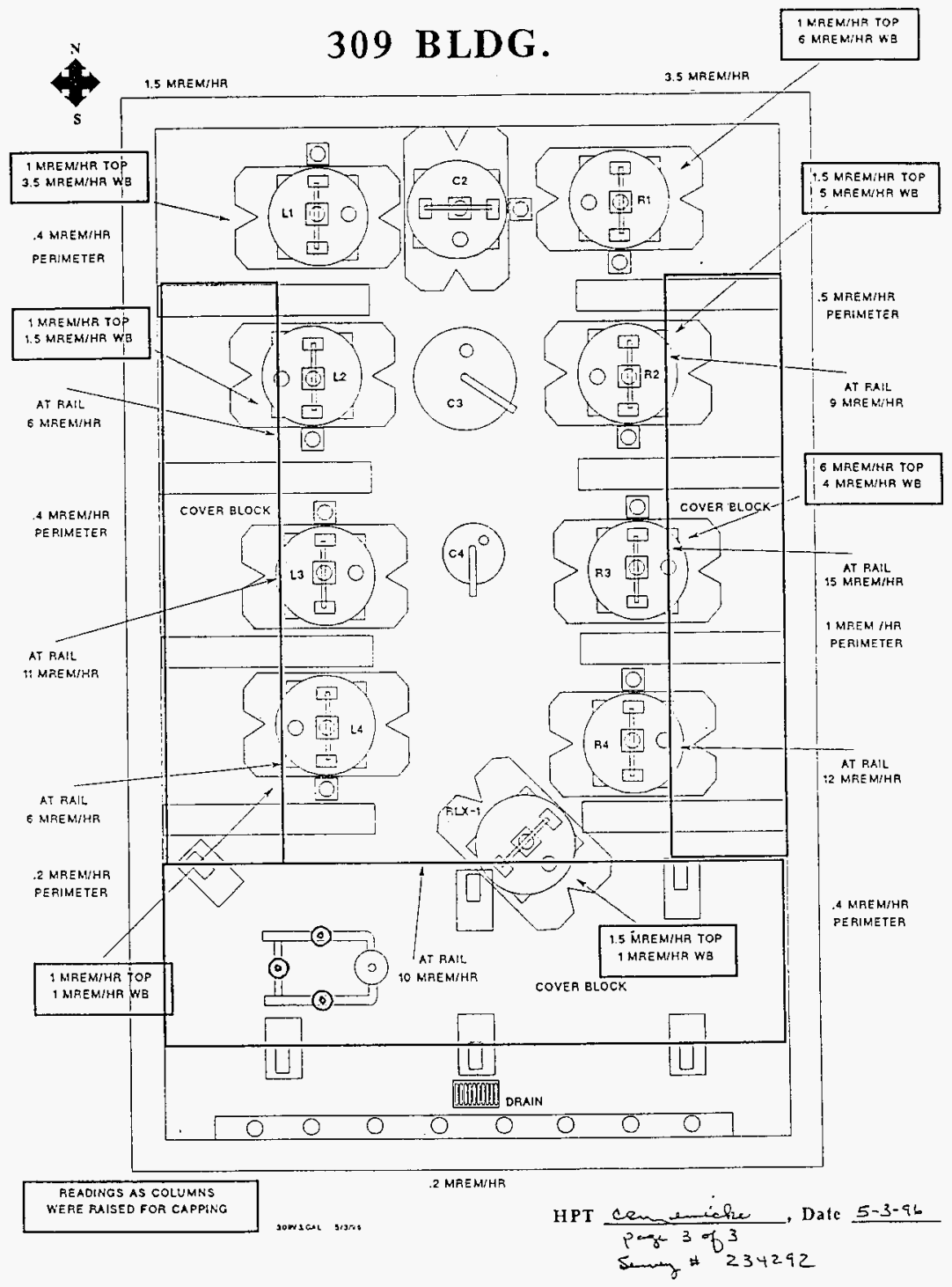




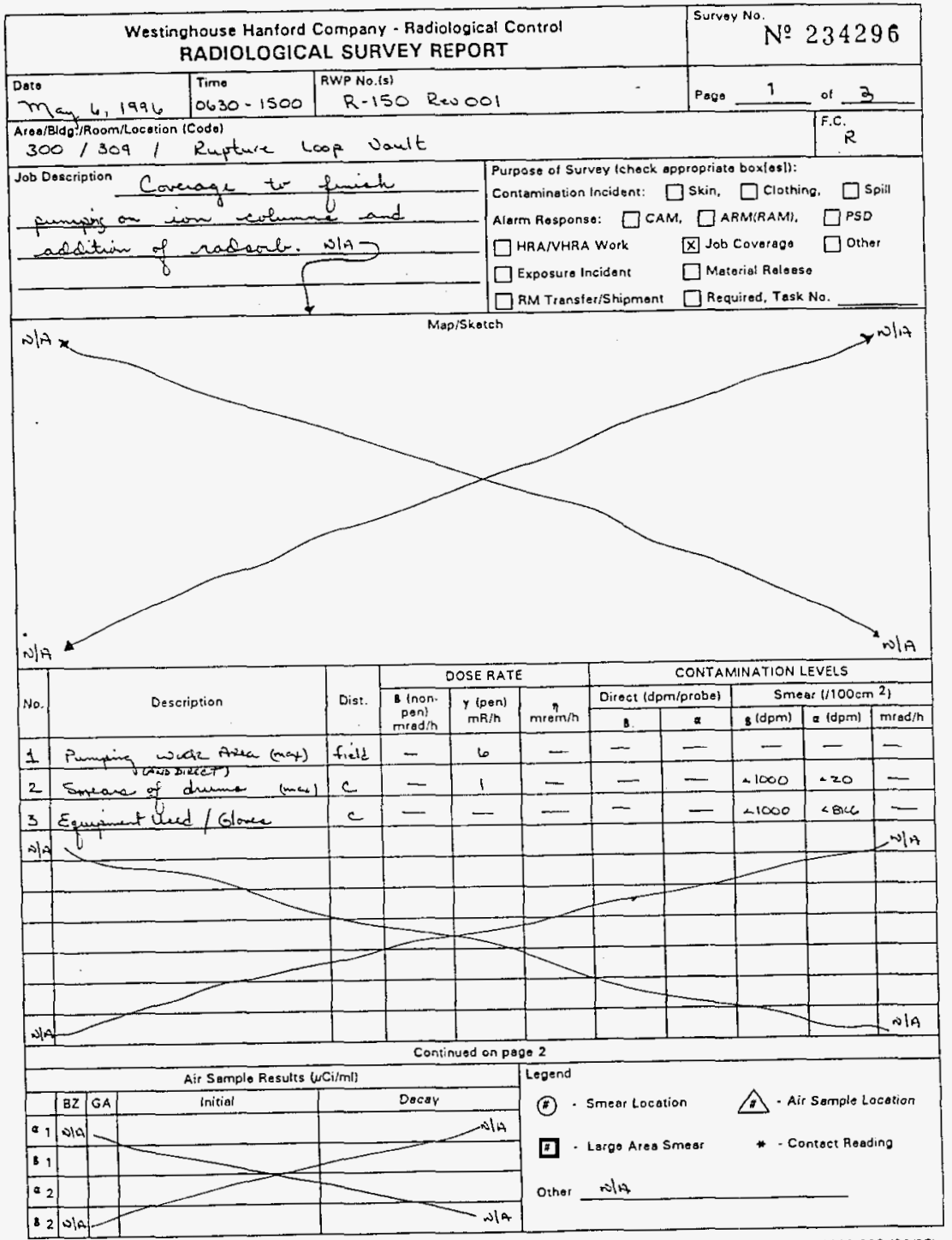




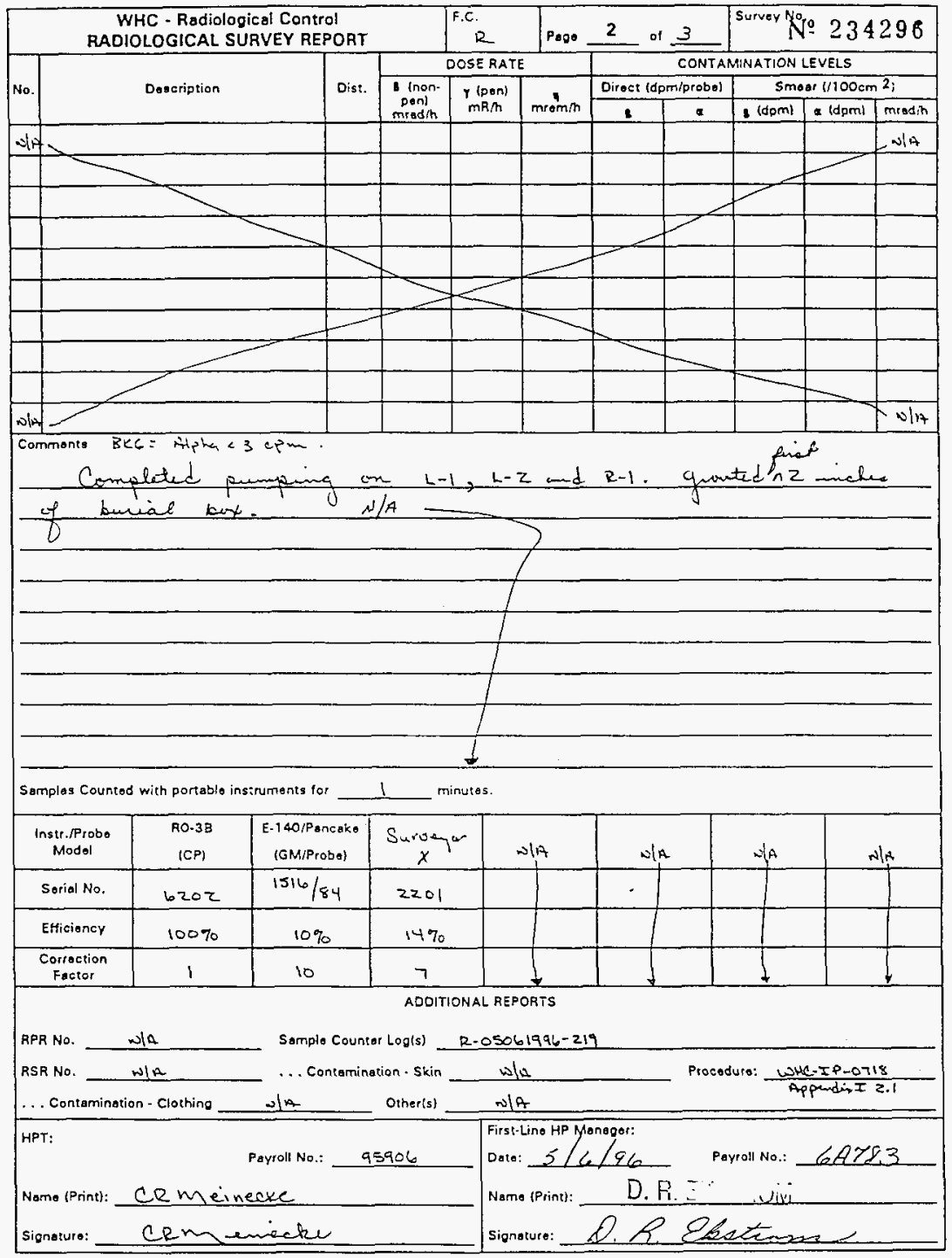




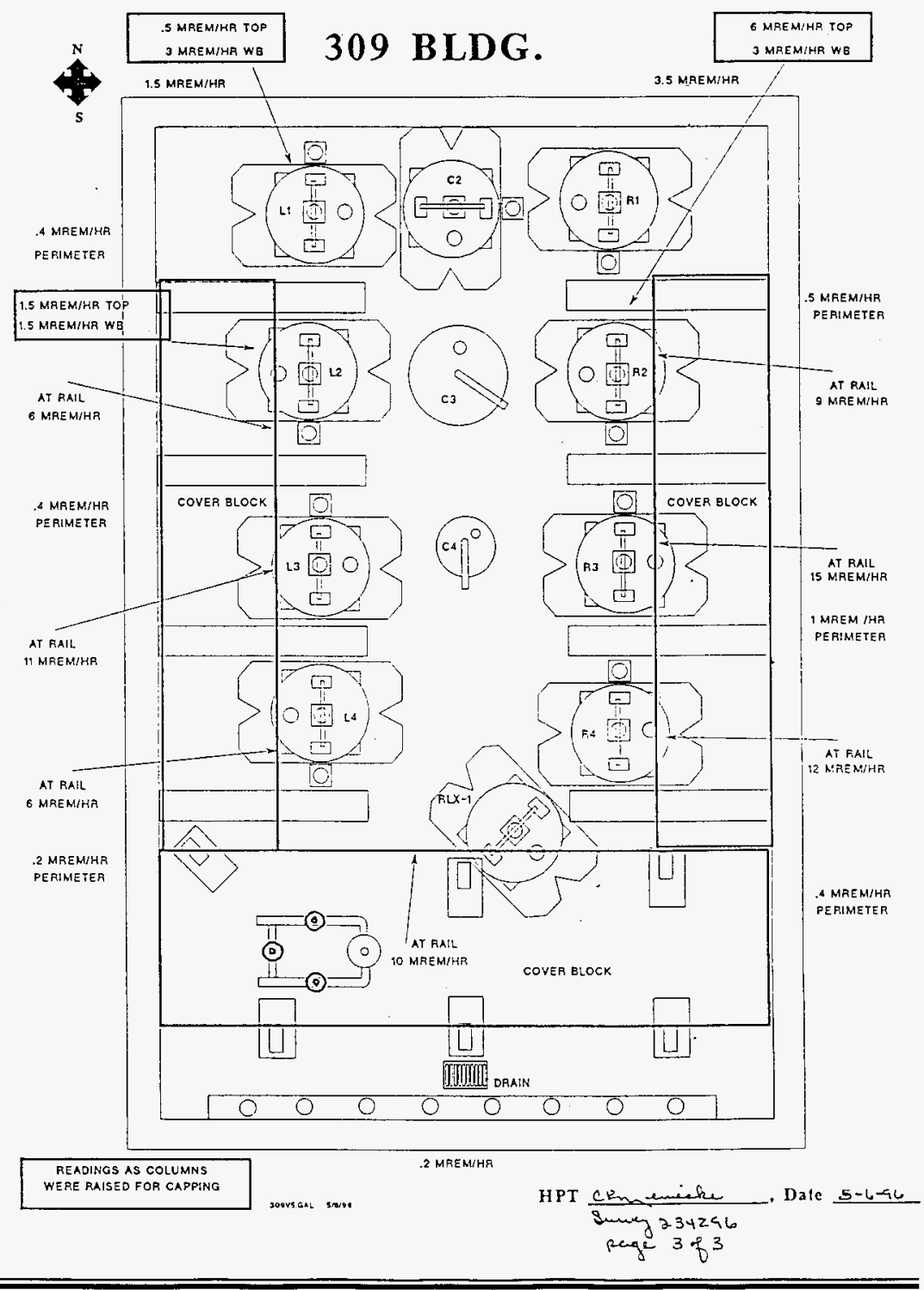




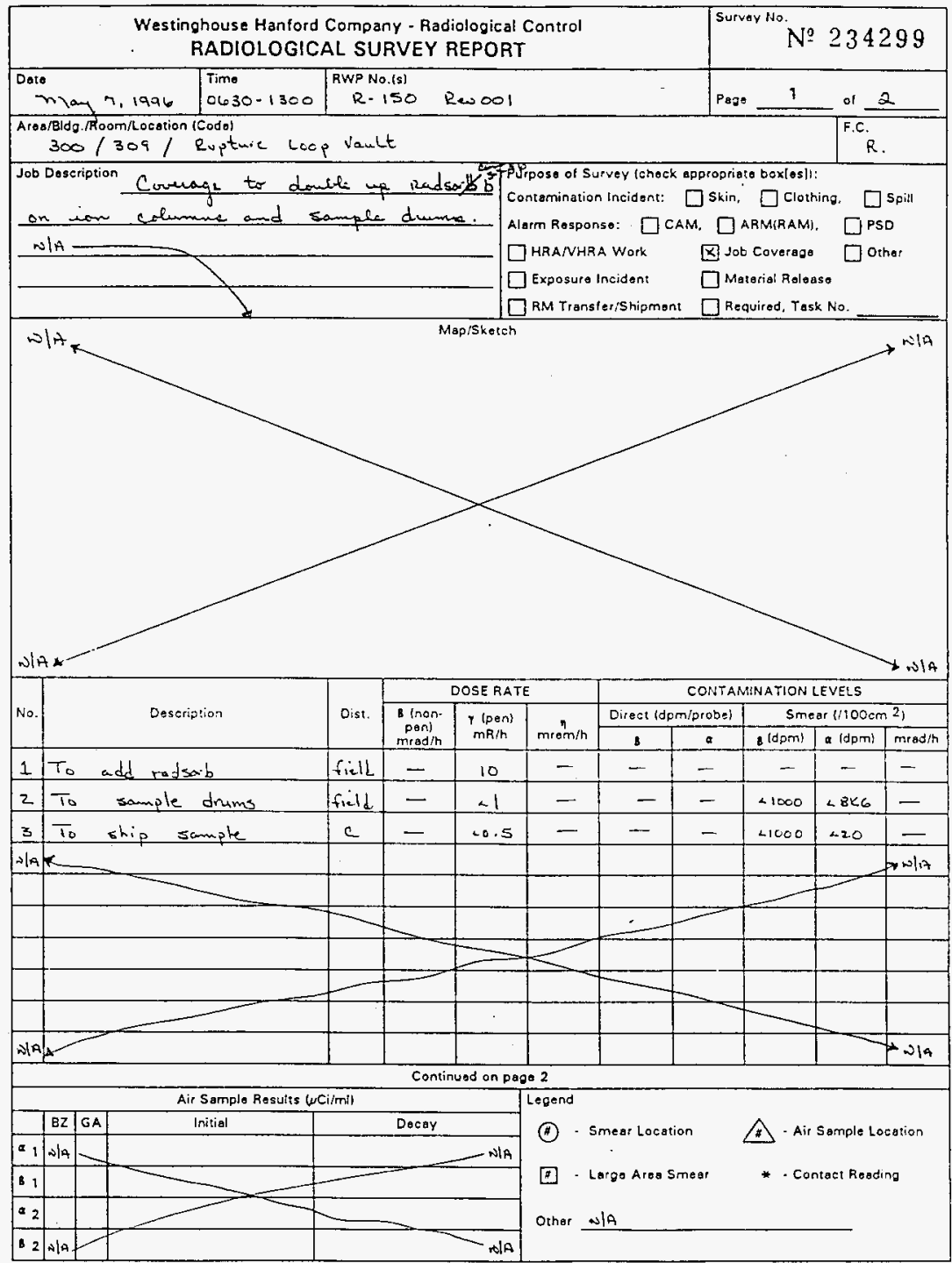

$B D \cdot 6000.010(03 / 95)$ 


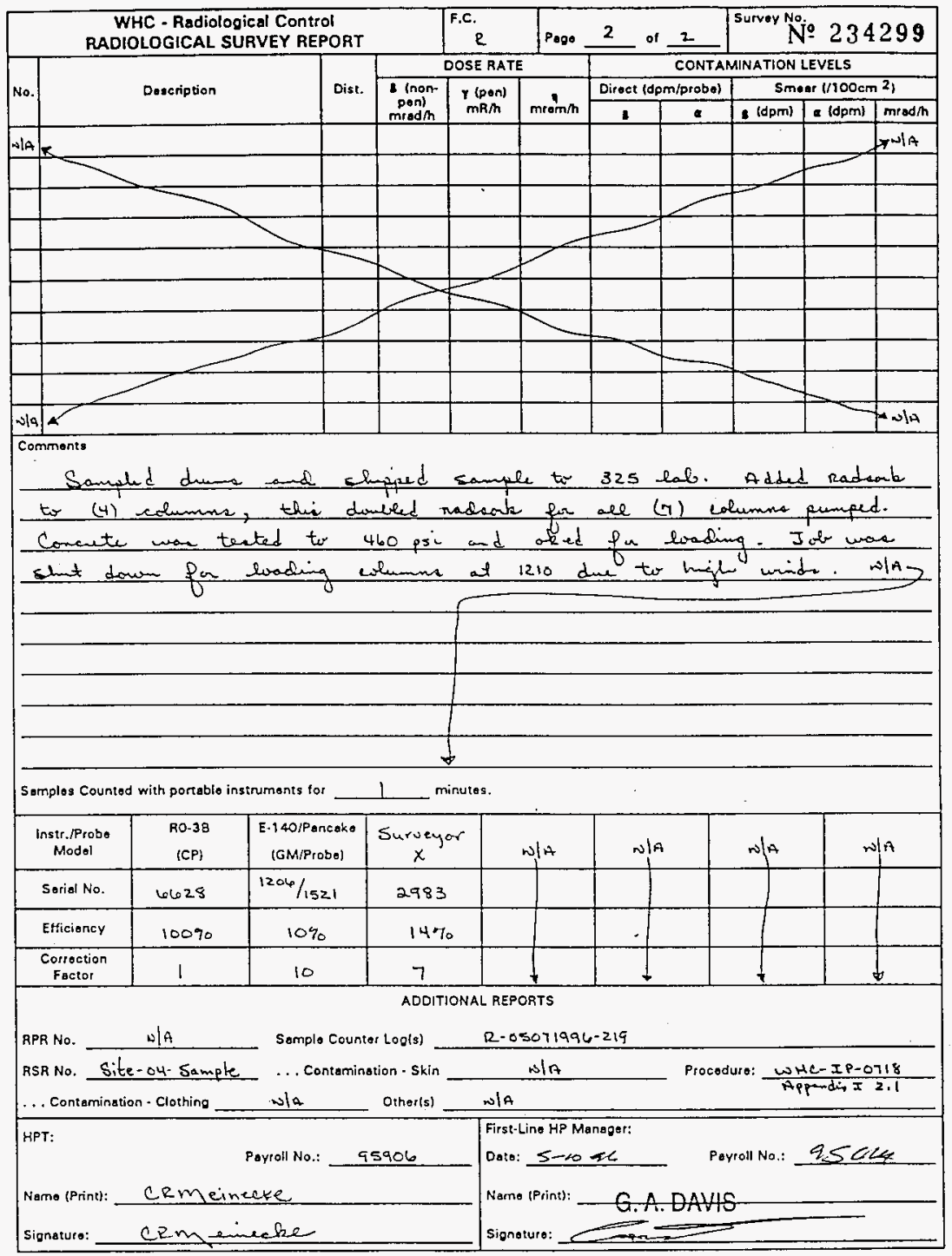




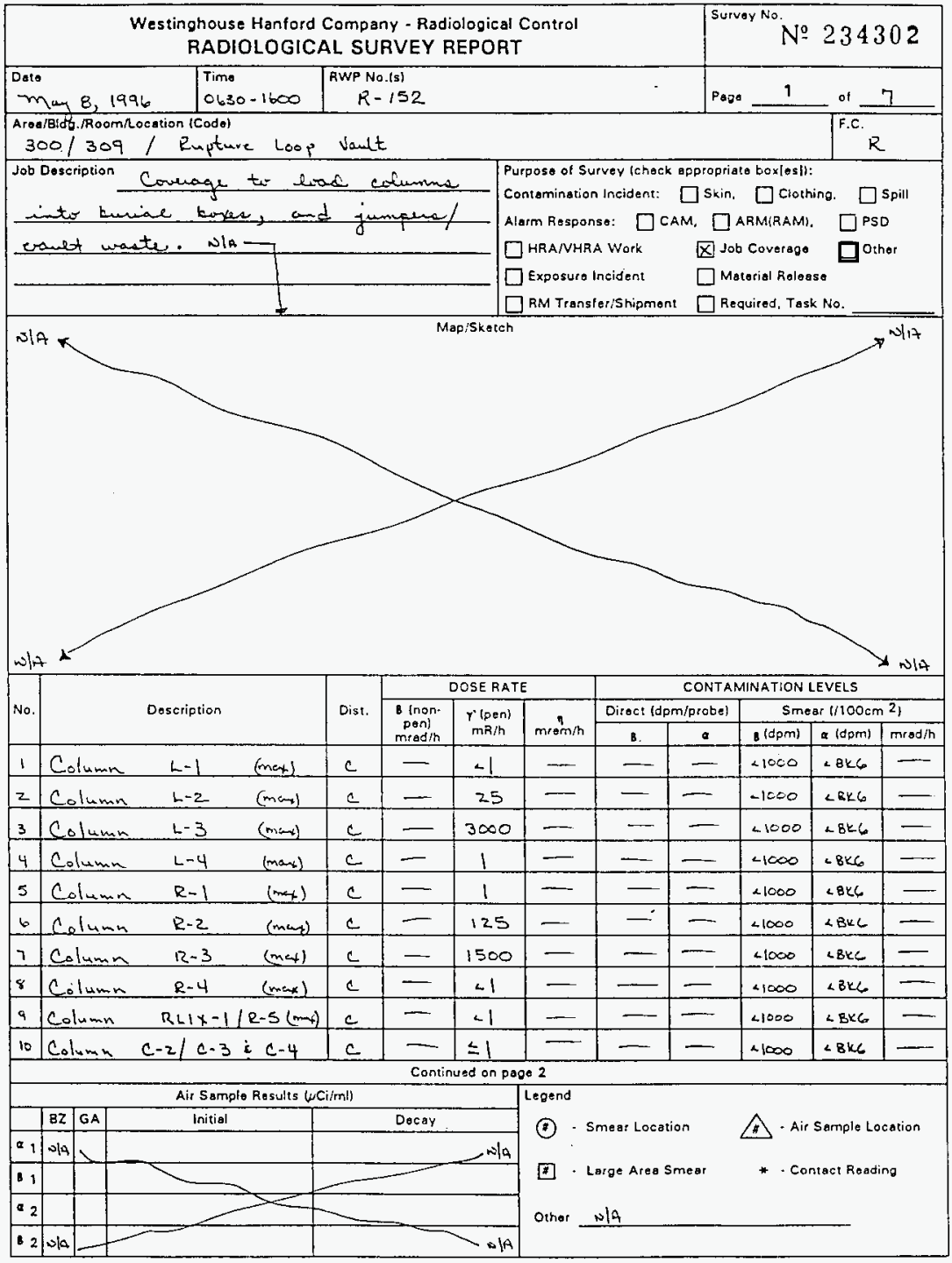




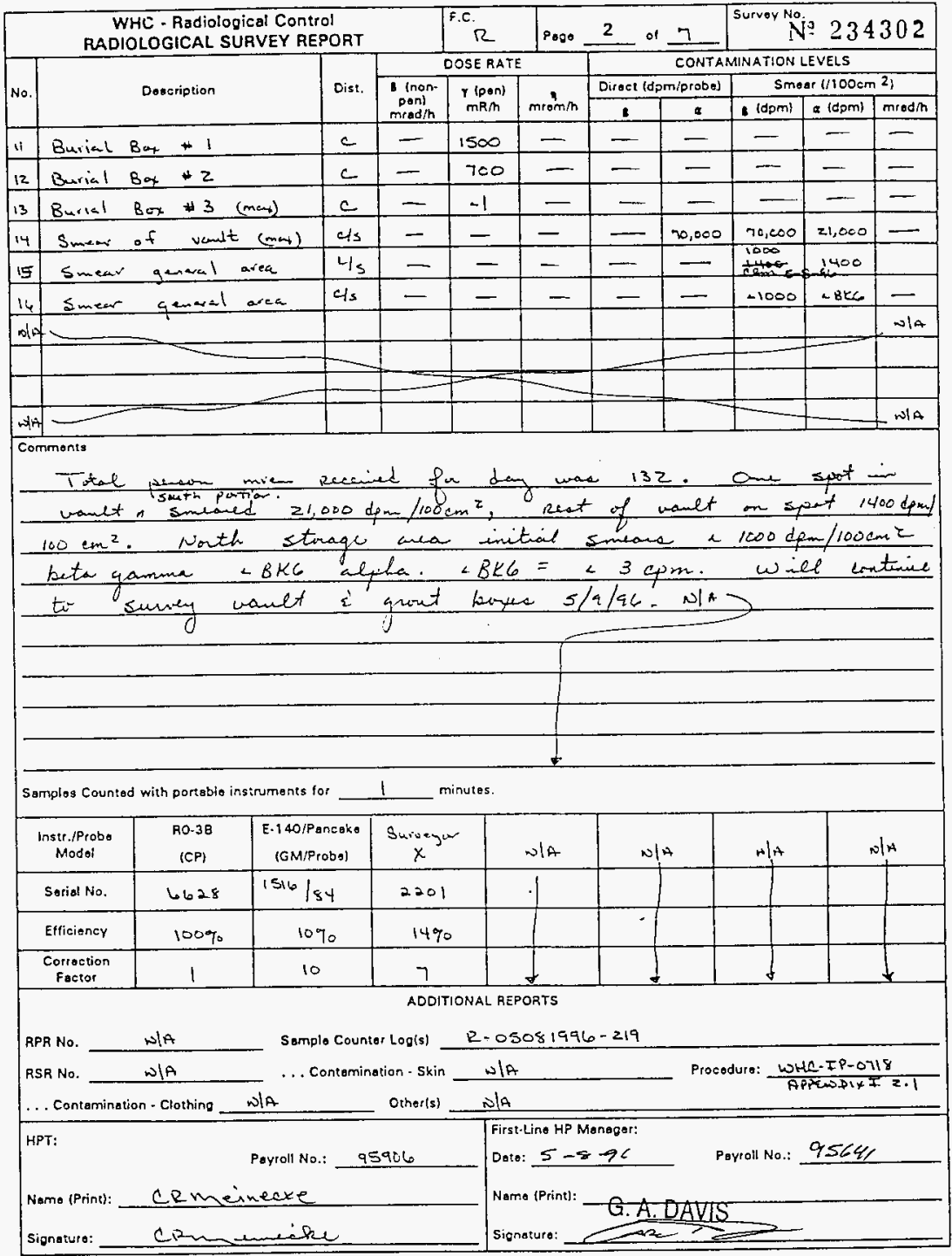



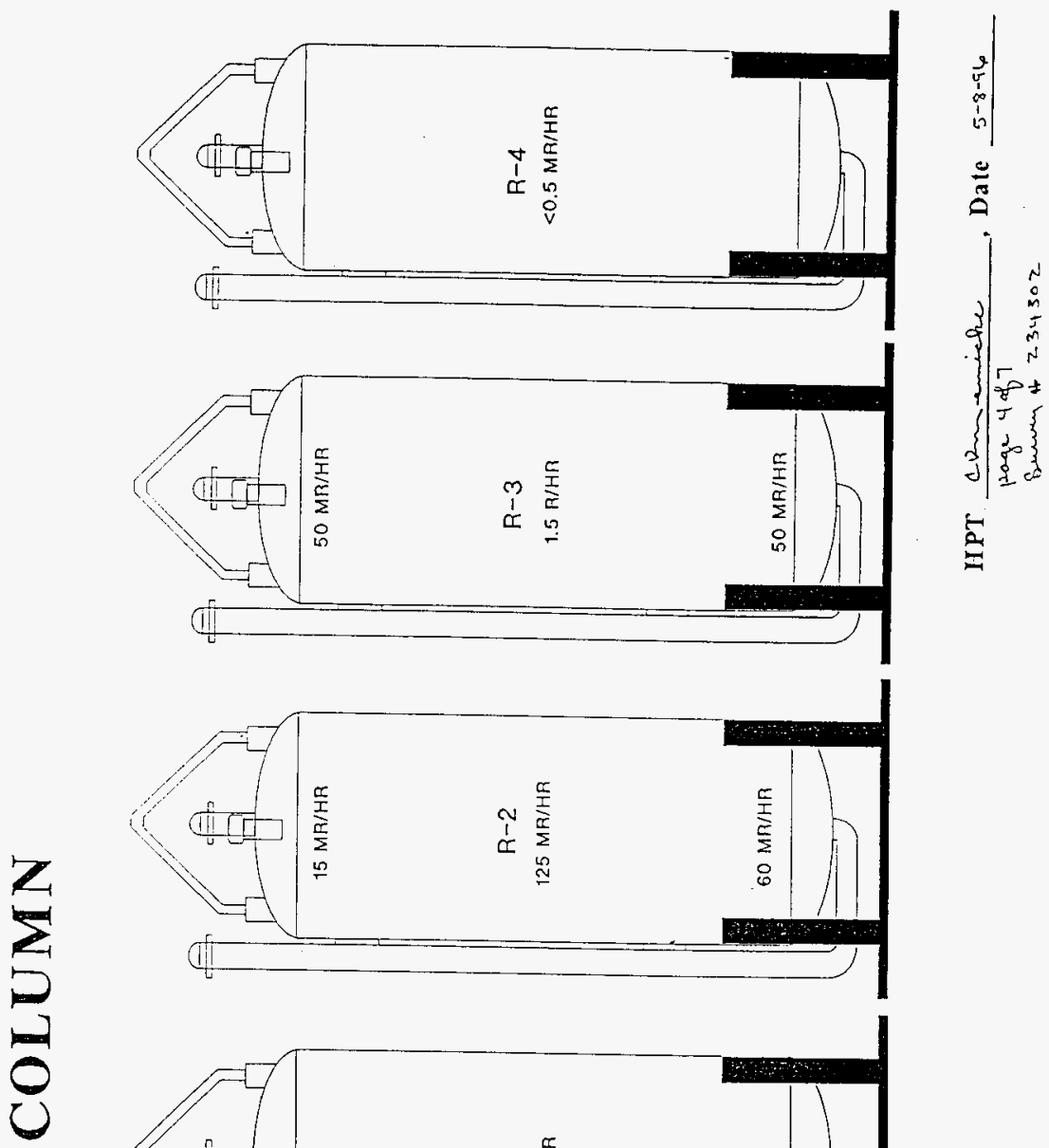

긍
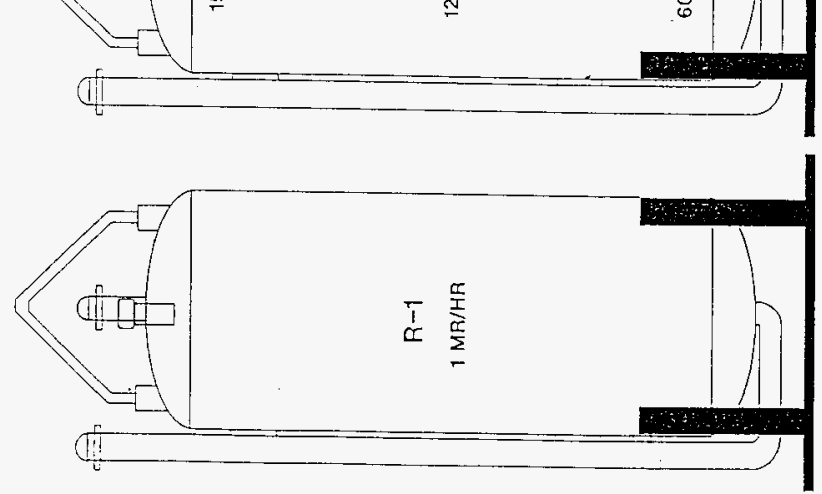

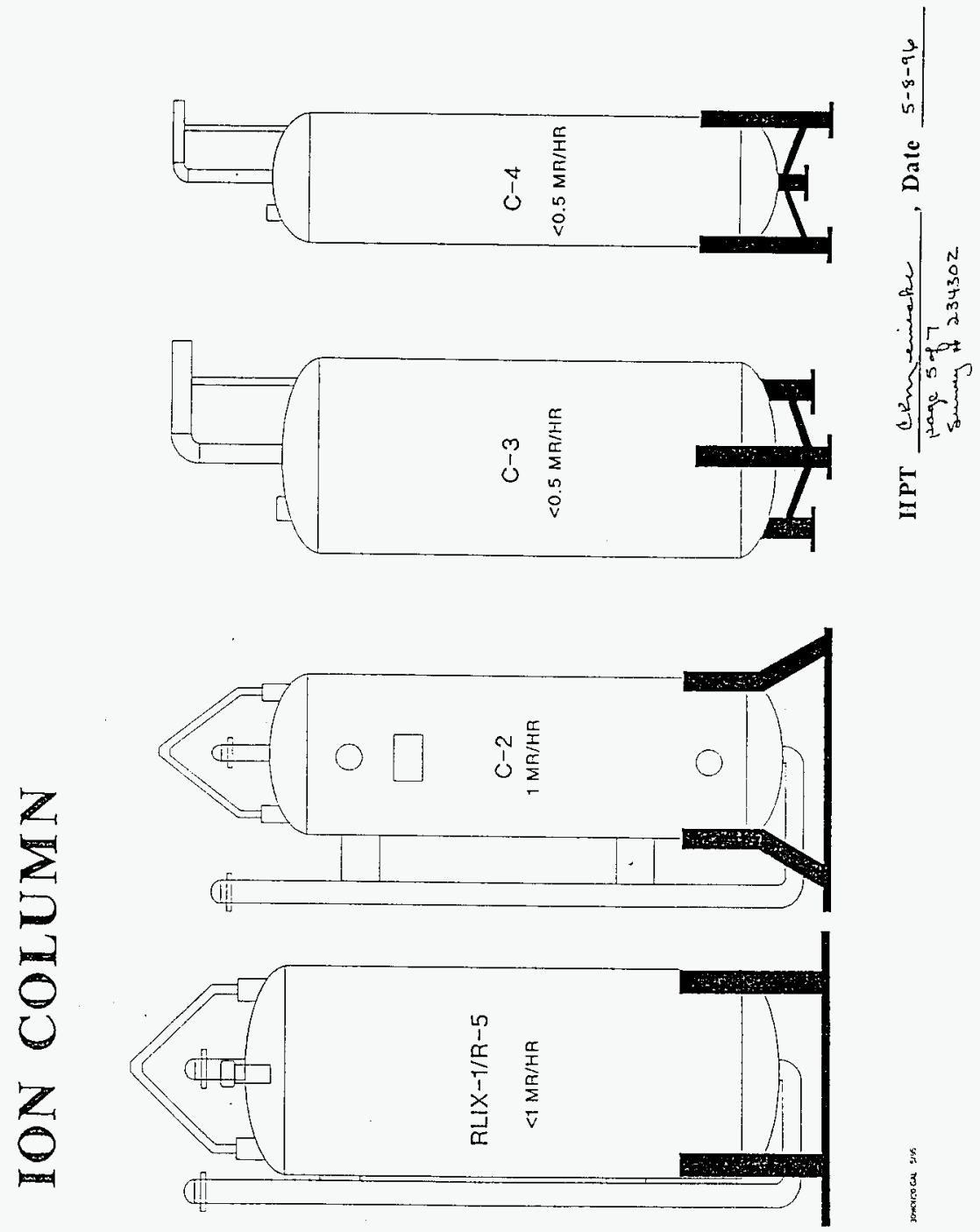

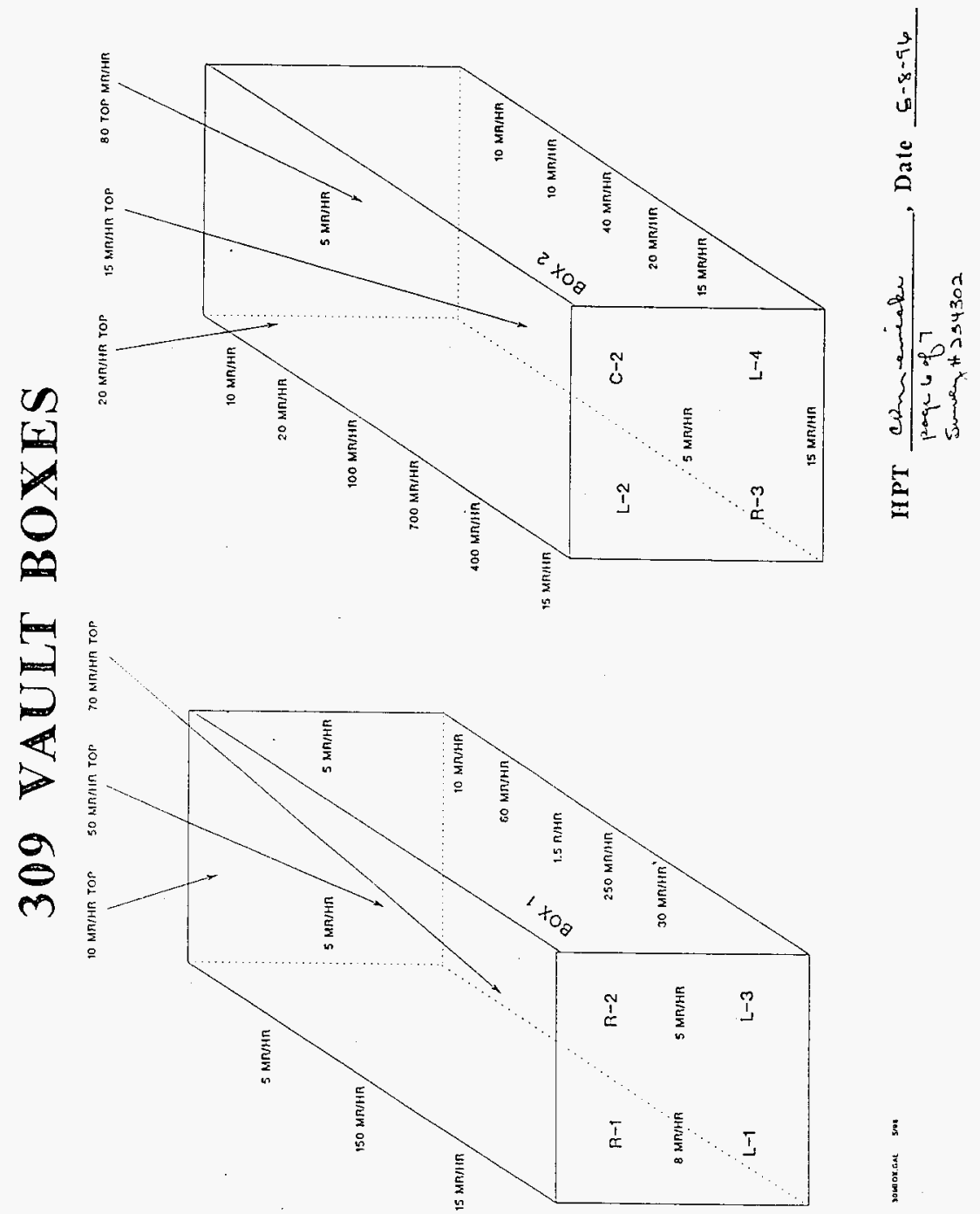
* 309 ION COLUMN VAULT

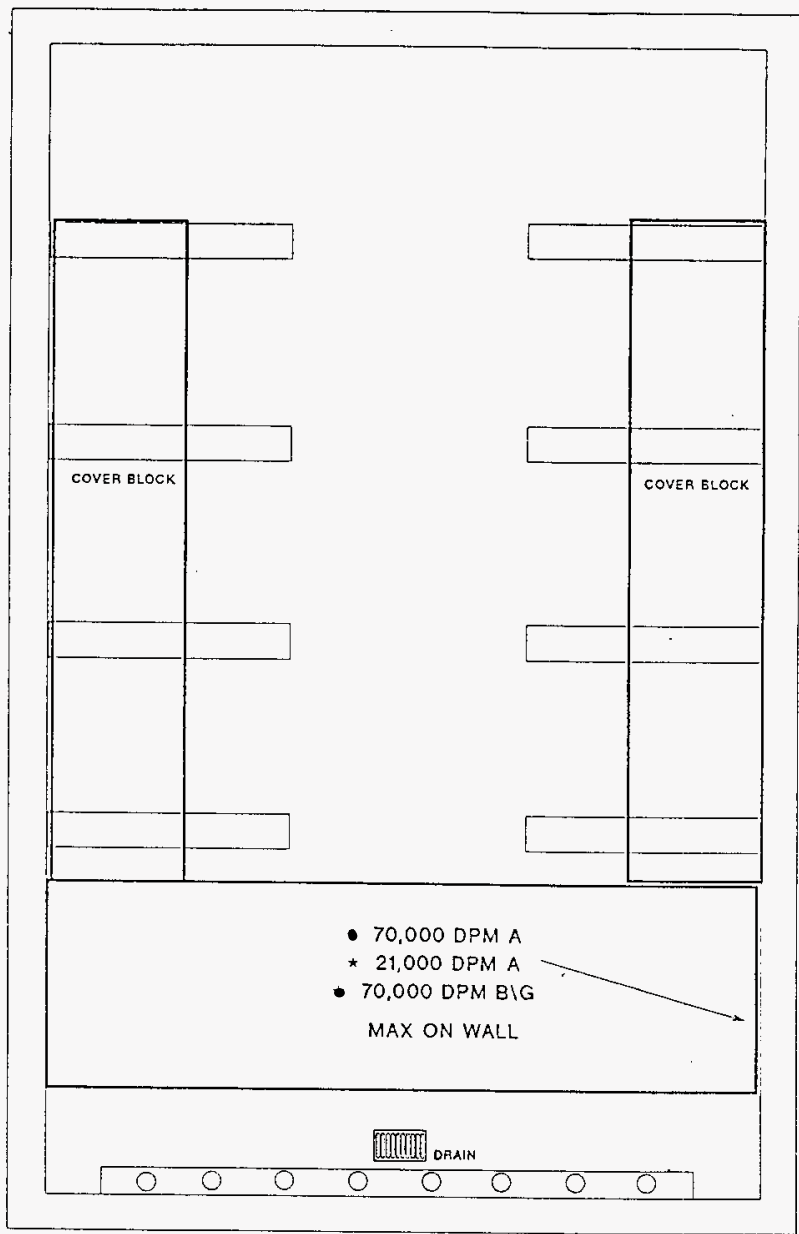


(S6/60) $010-0009 \cdot 08$

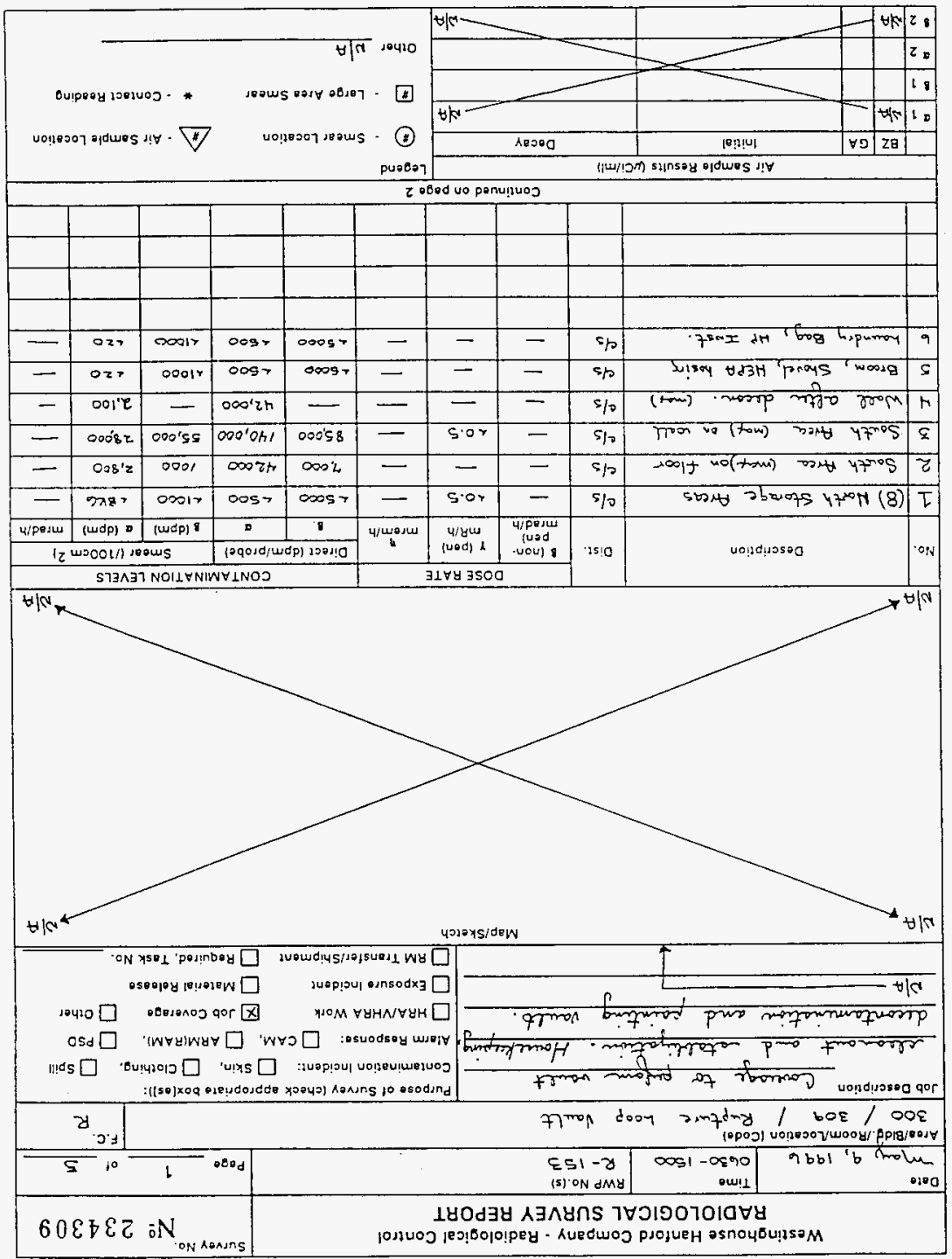




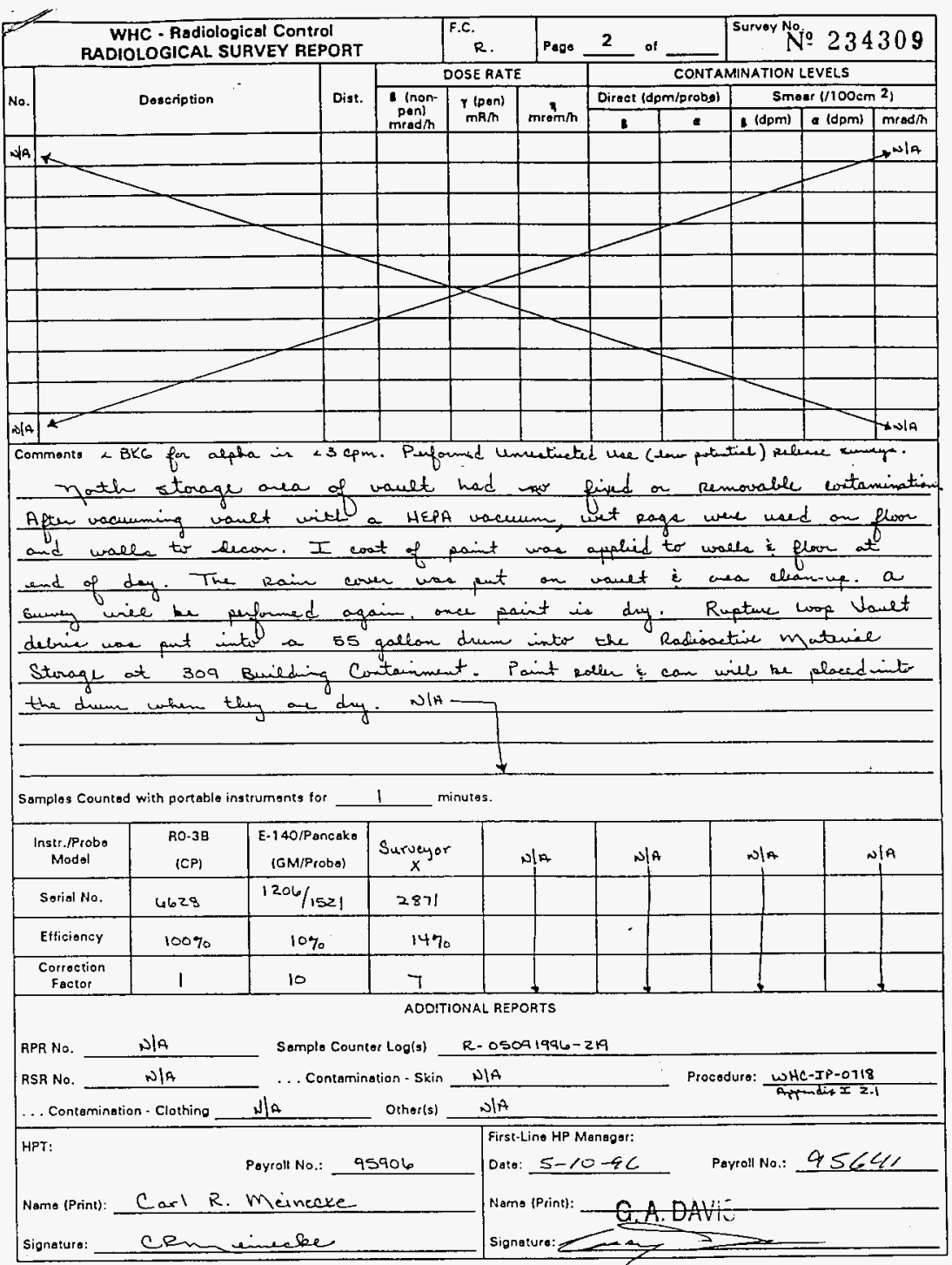


* 309 ION COLUMN VAULT

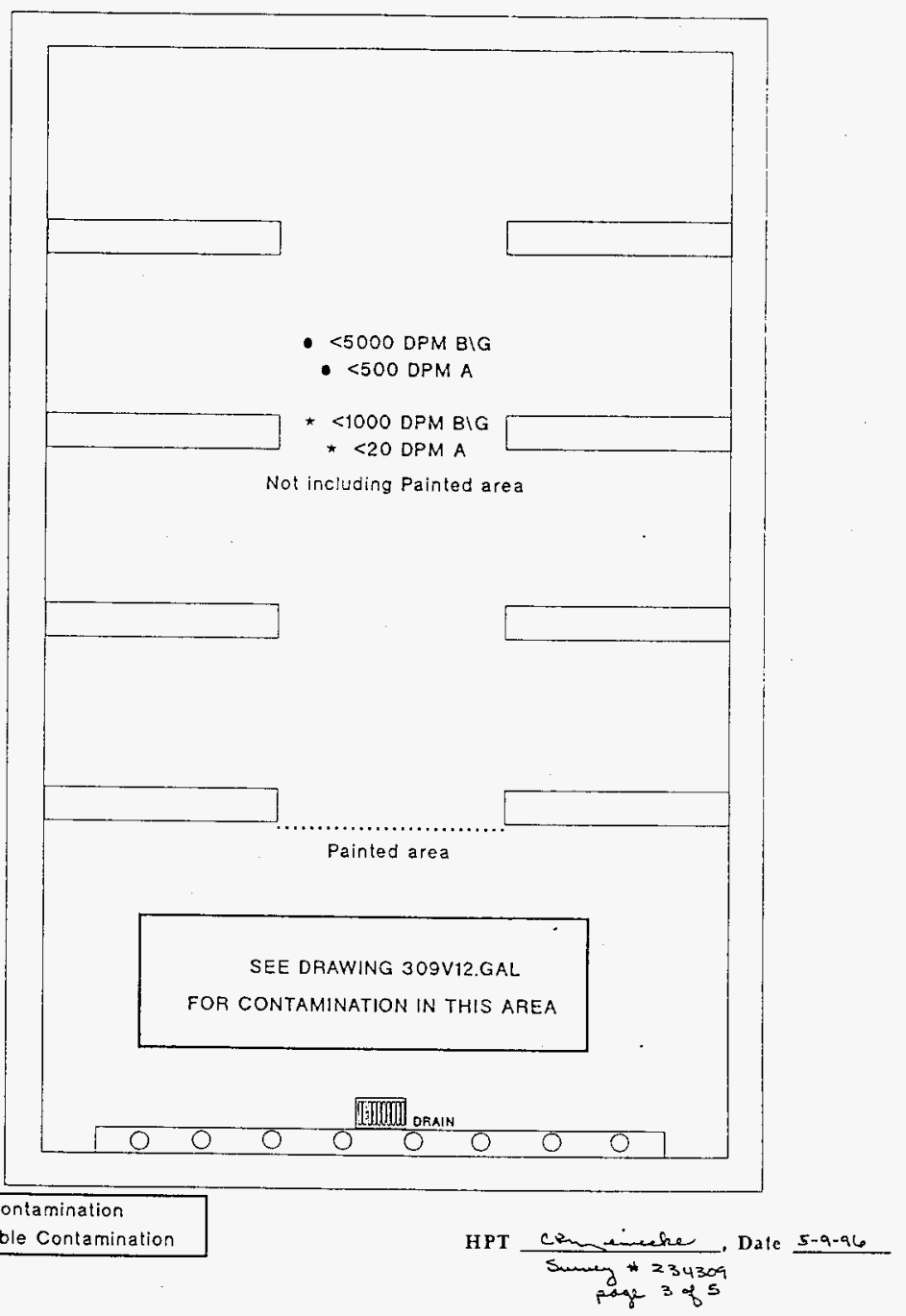




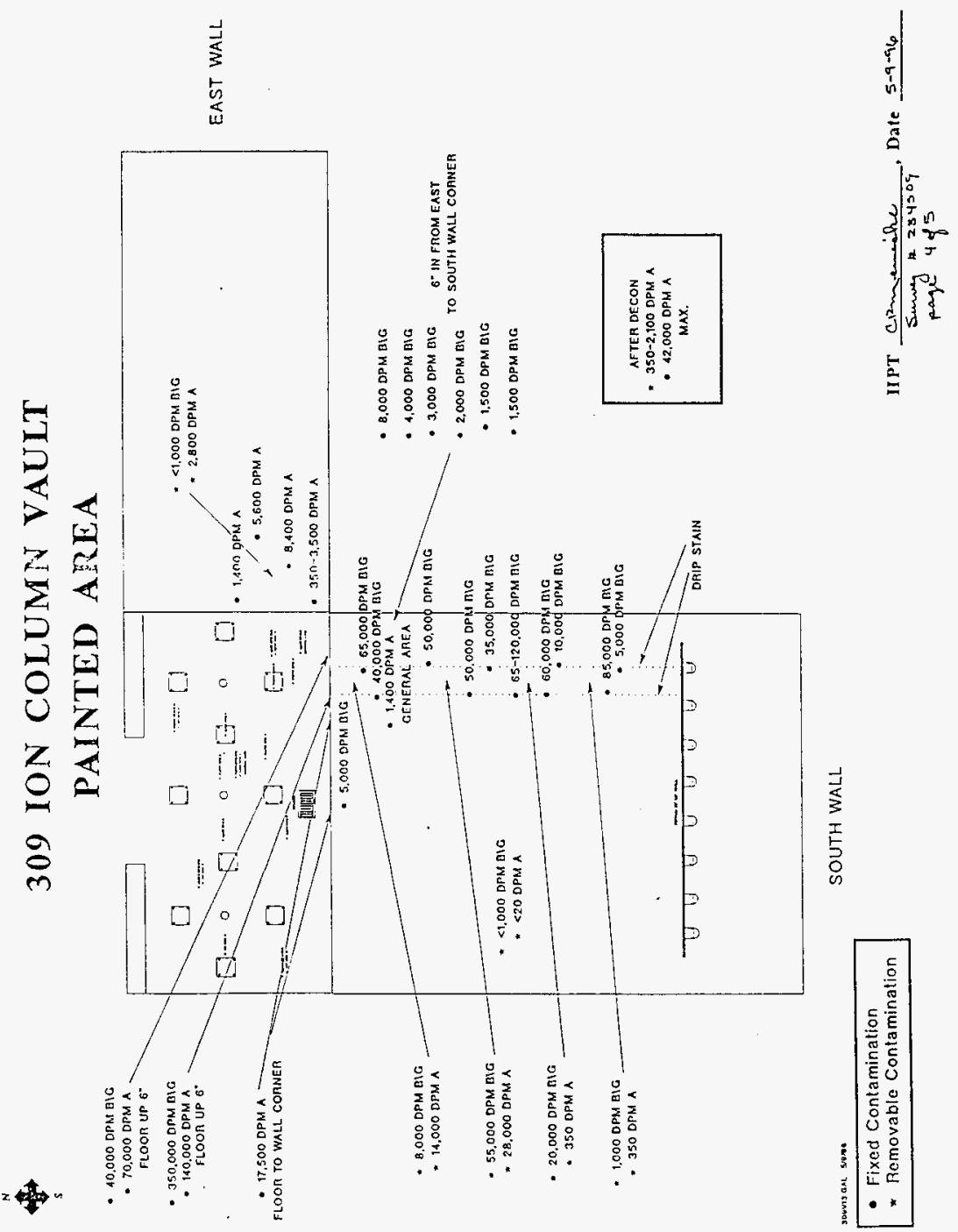




\section{WHC-SD-NEL-ER-004 Rev. 0}

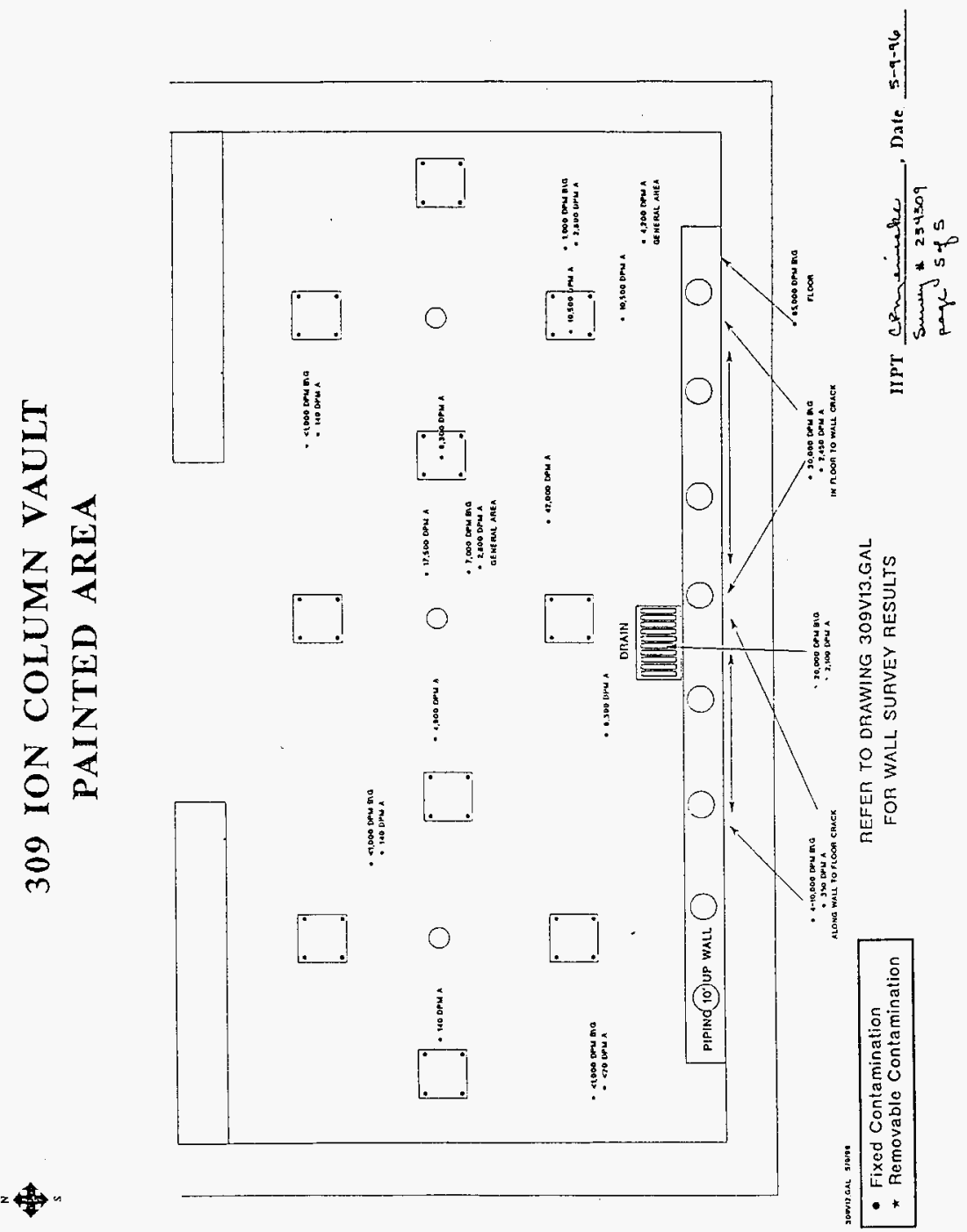




\section{WHC-SD-NEL-ER-004 Rev. 0}

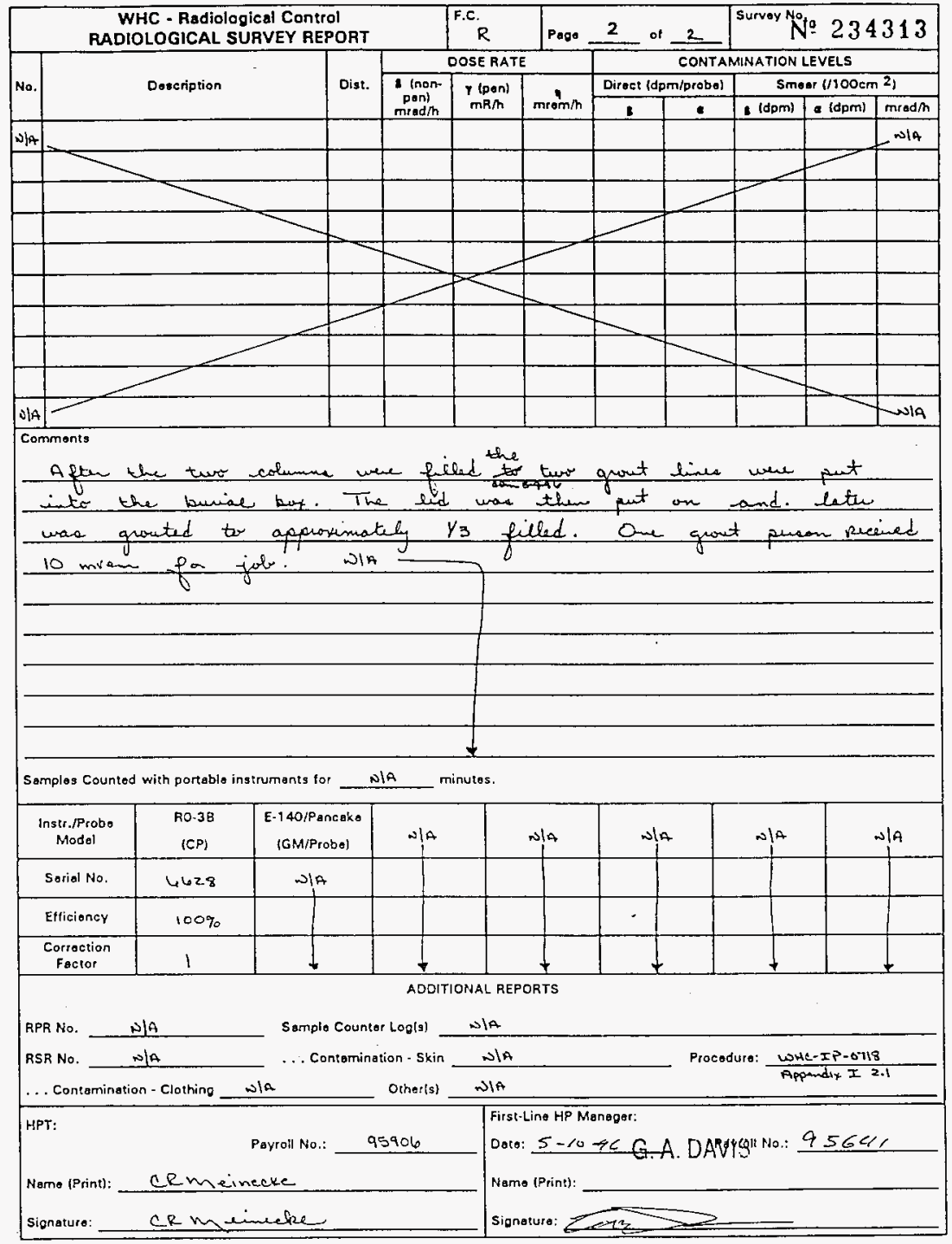




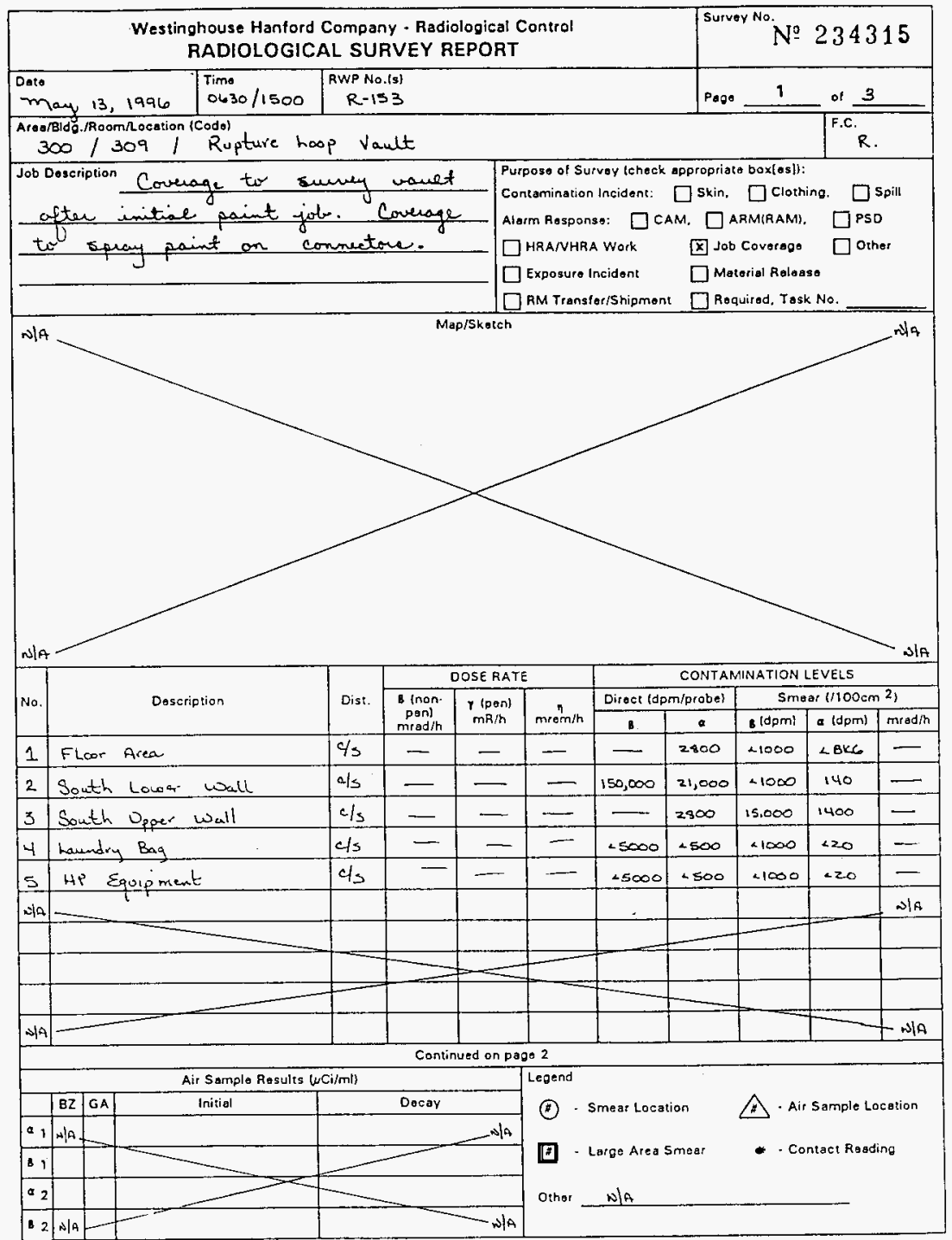




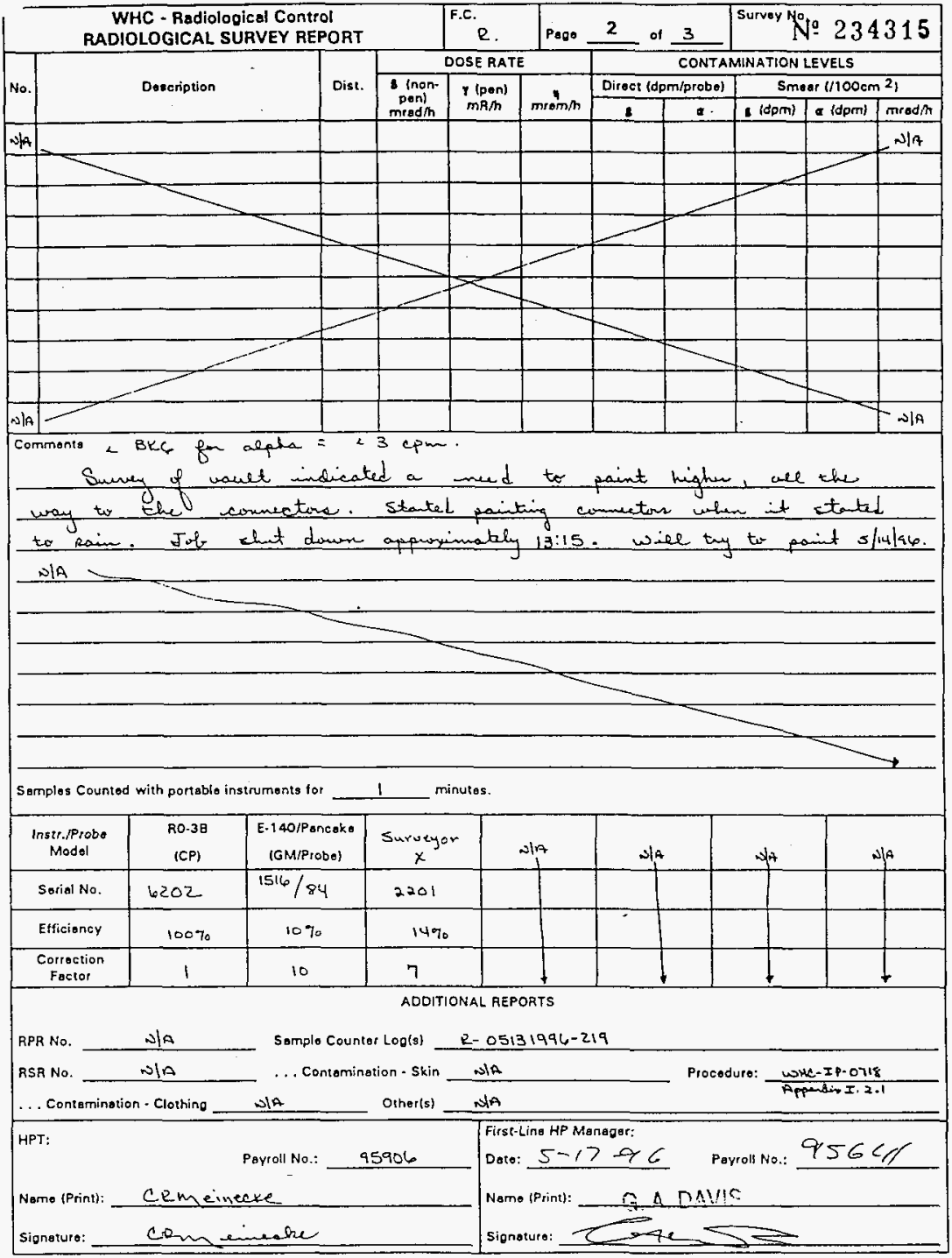




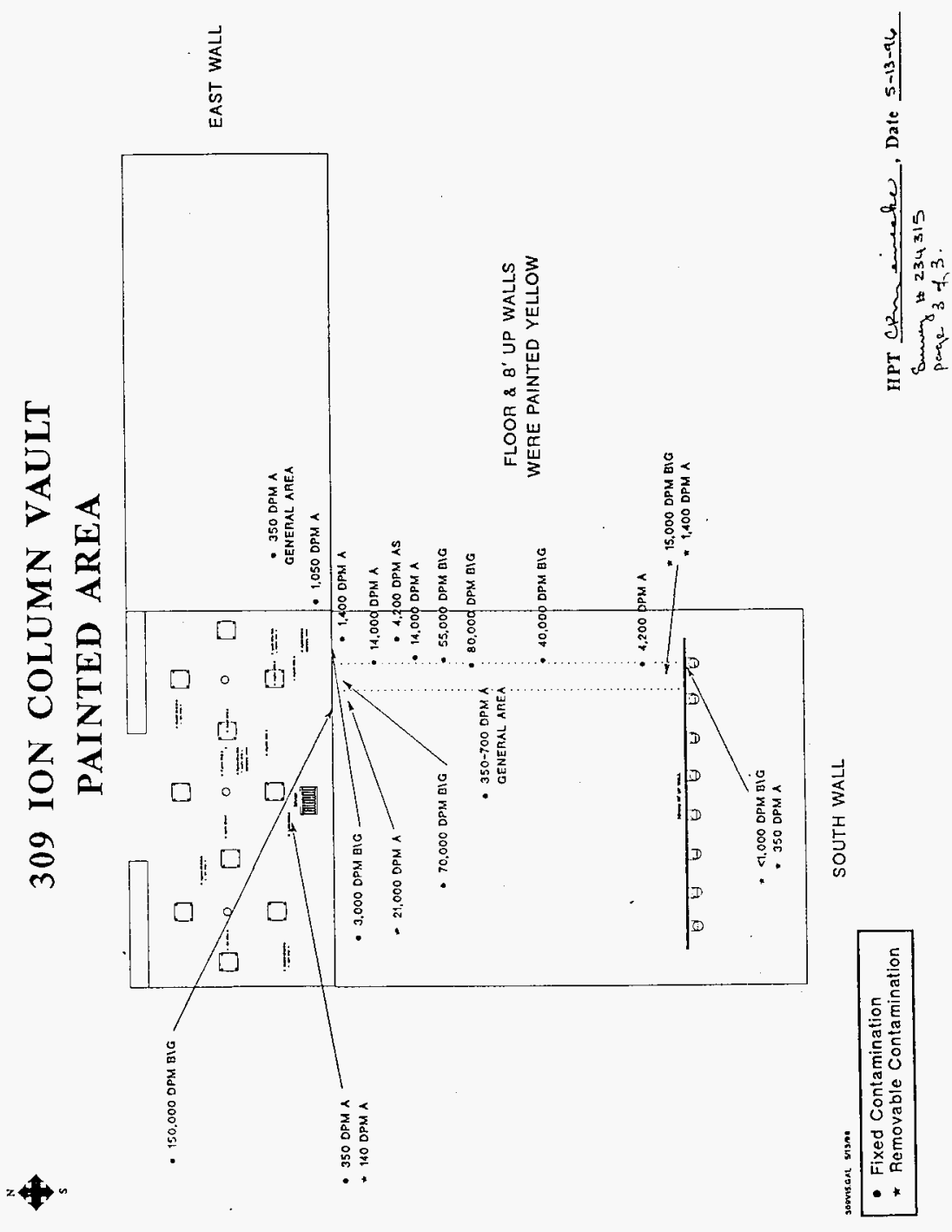




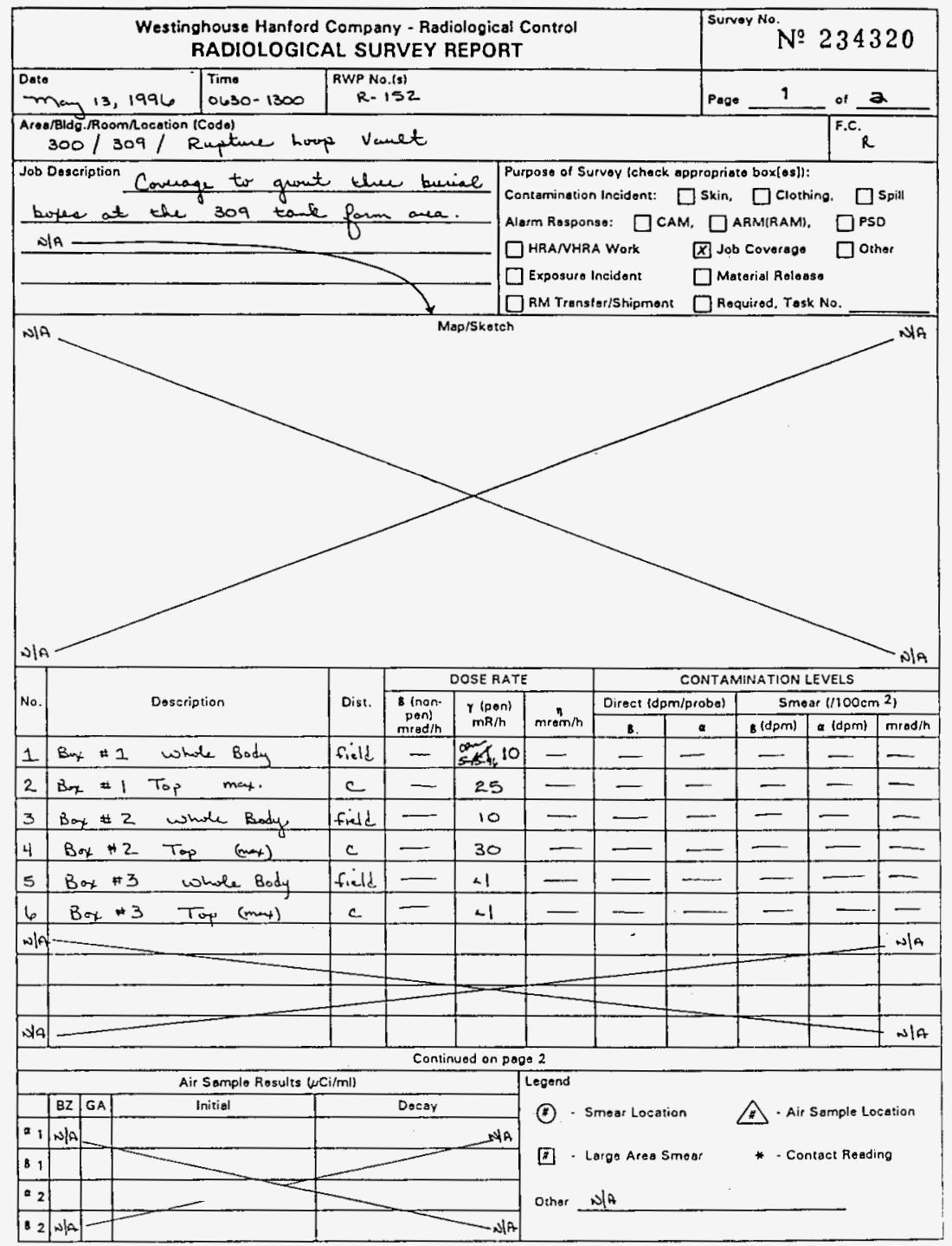




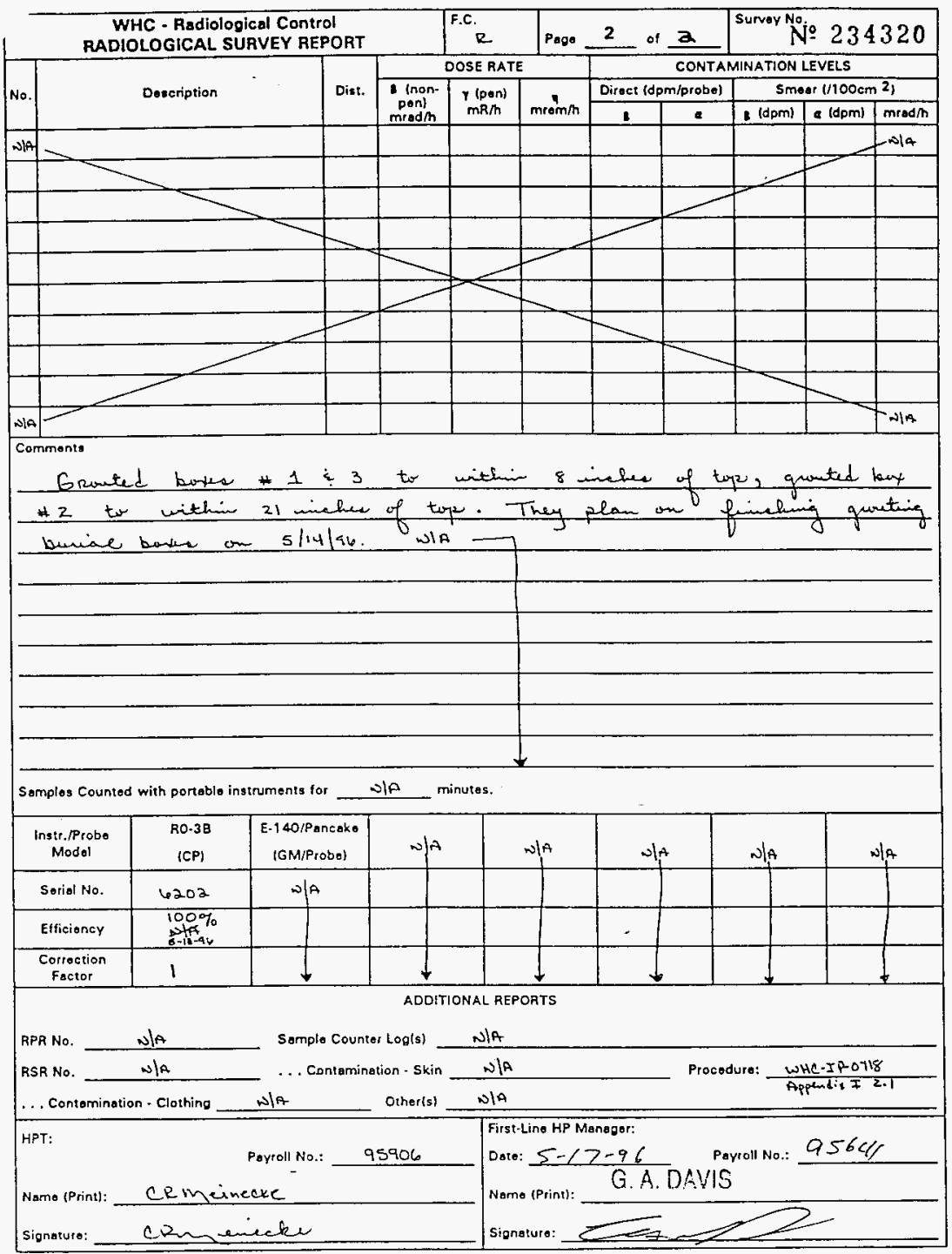




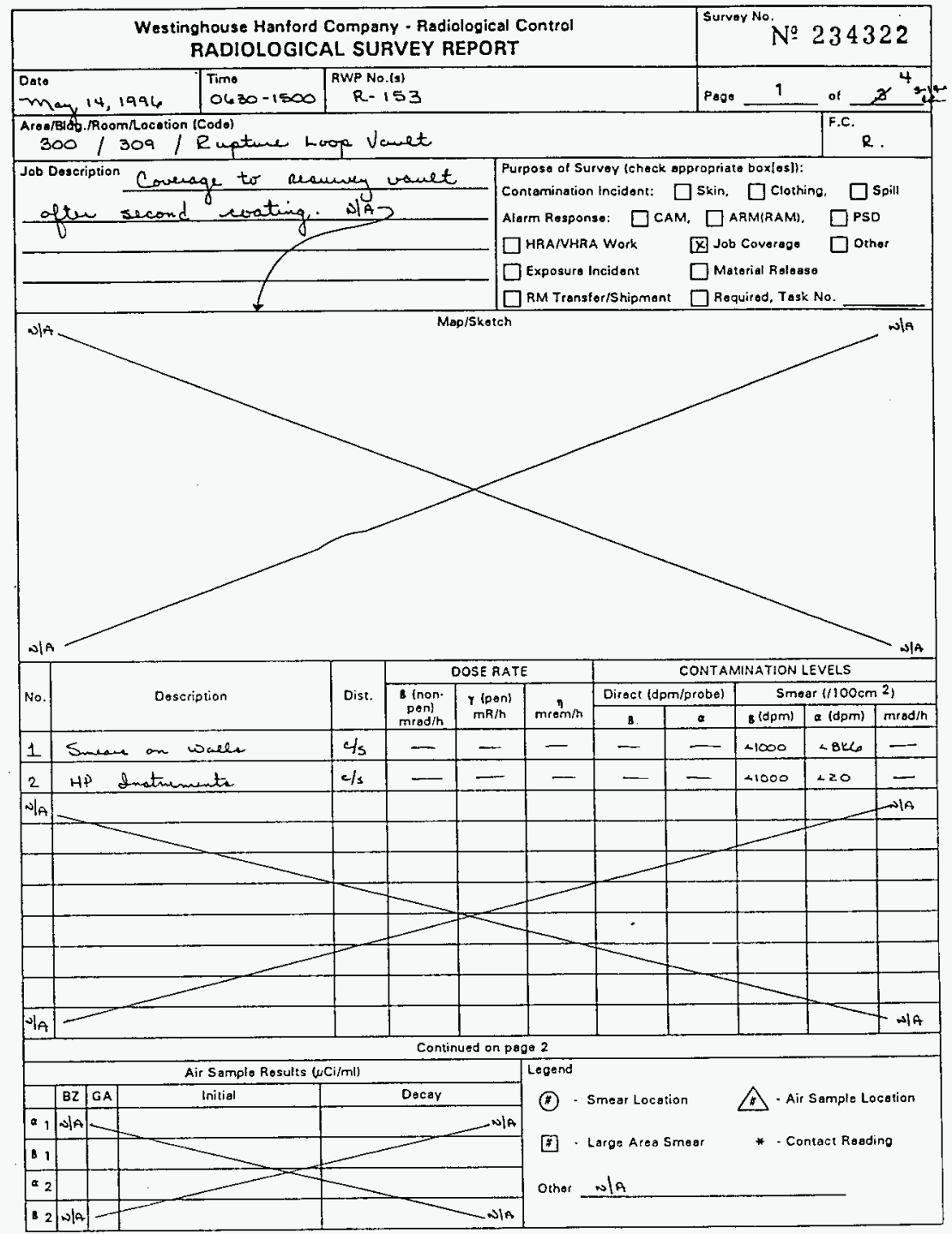




\section{WHC-SD-NEL-ER-004 Rev. 0}

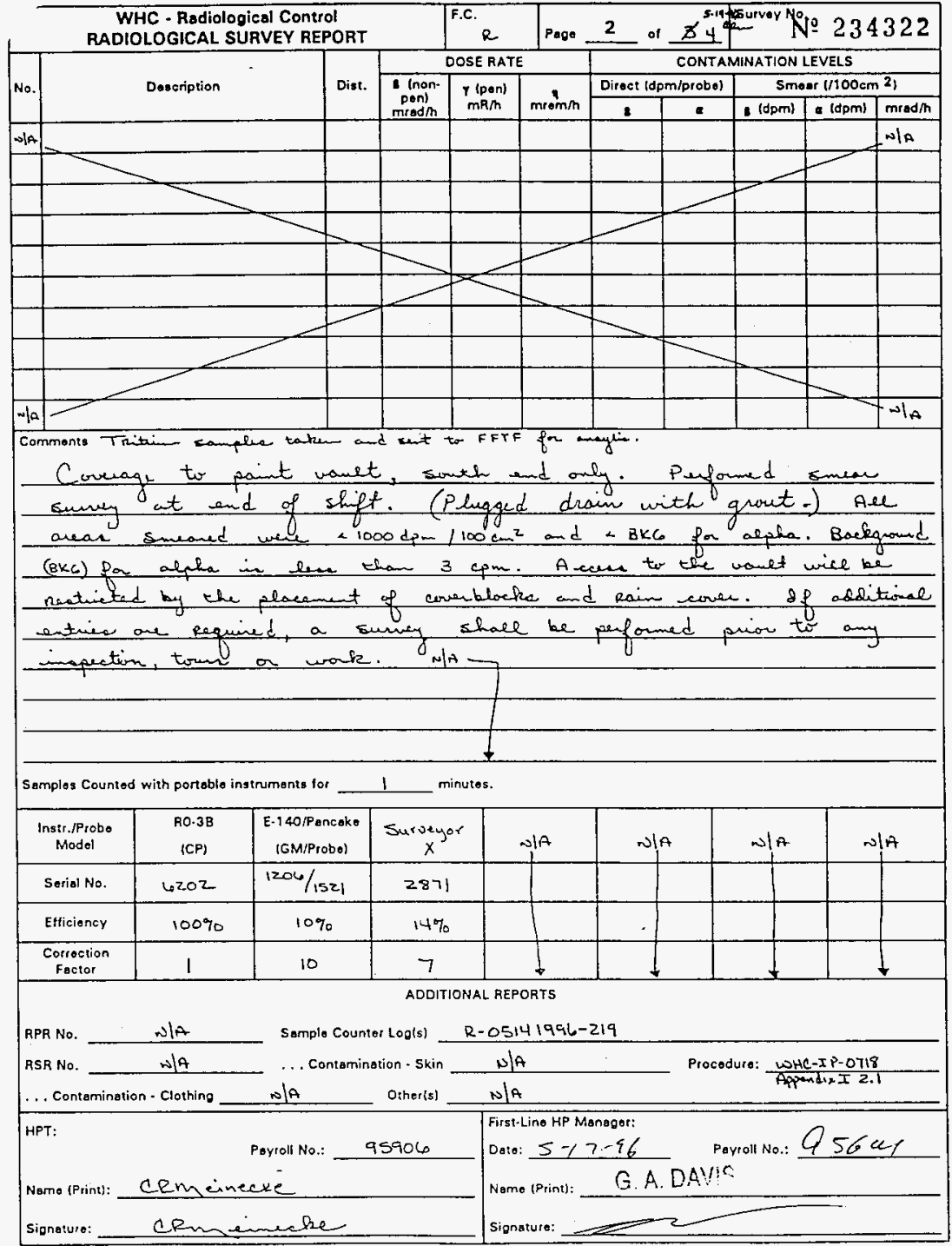




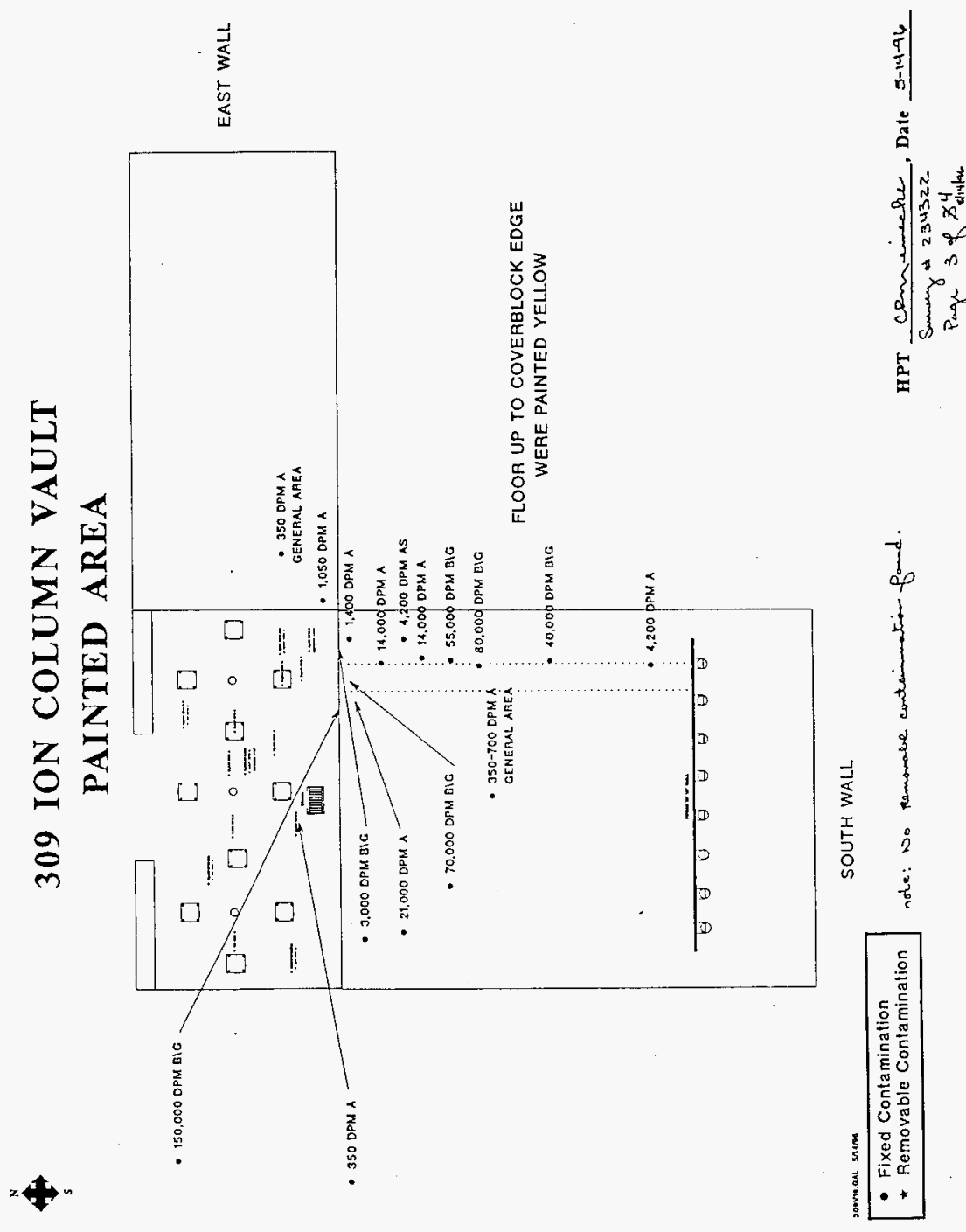




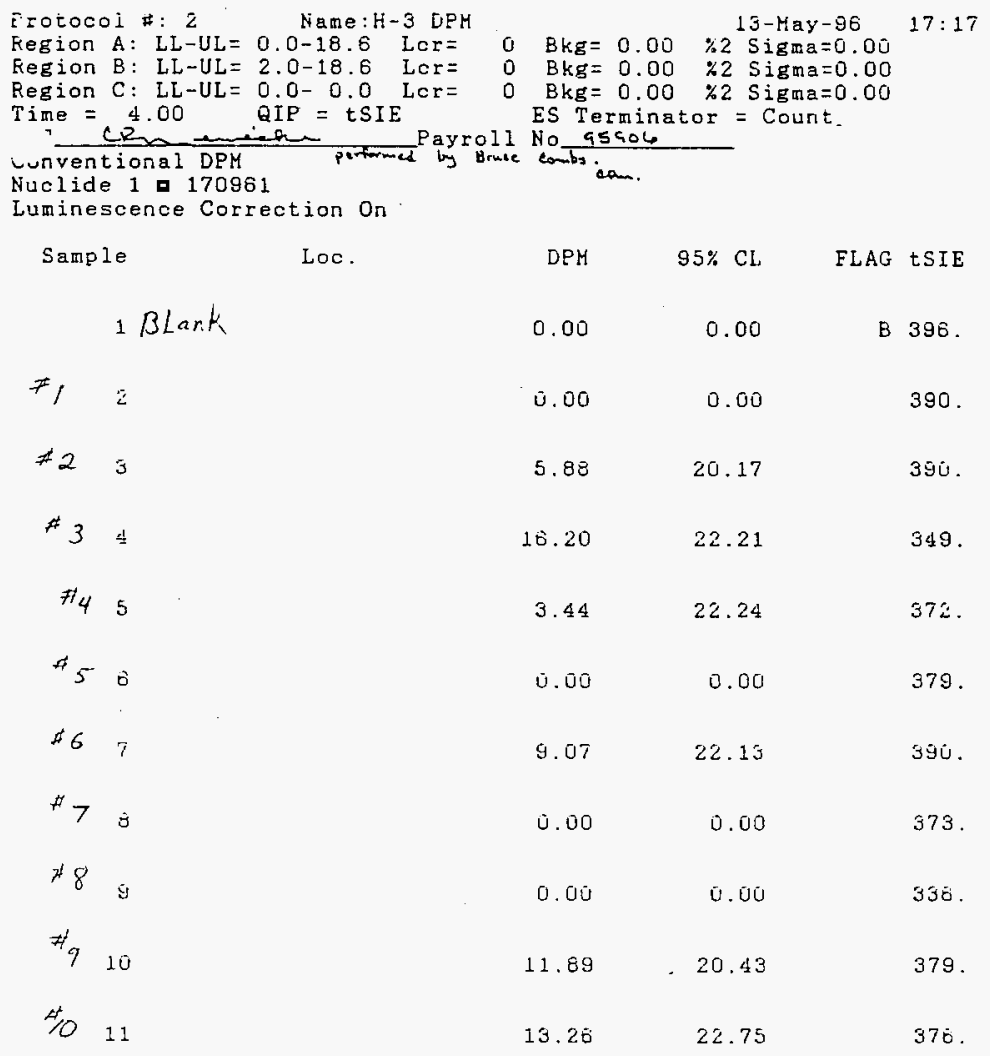

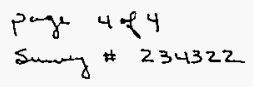




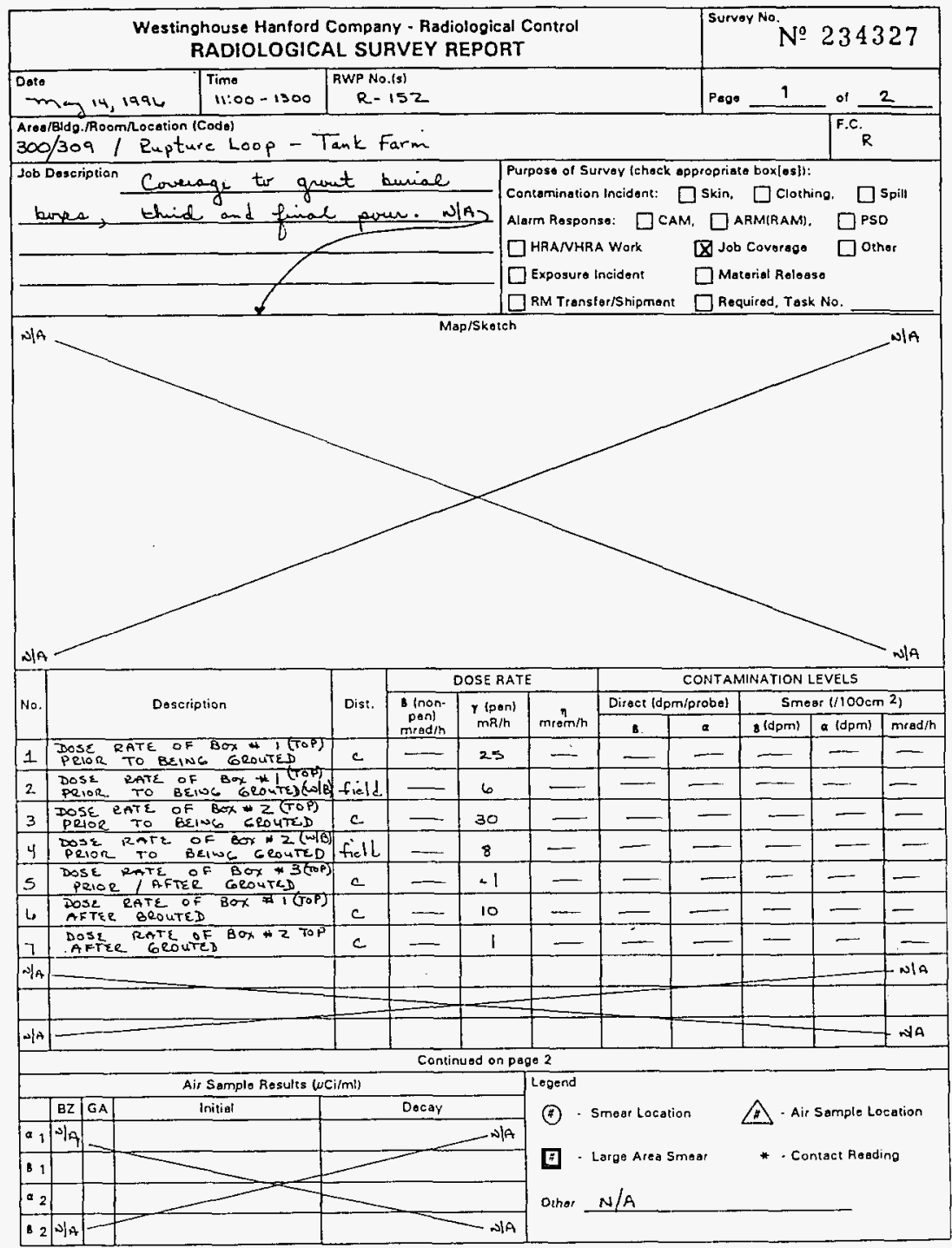

8D-6000-010 103/95 


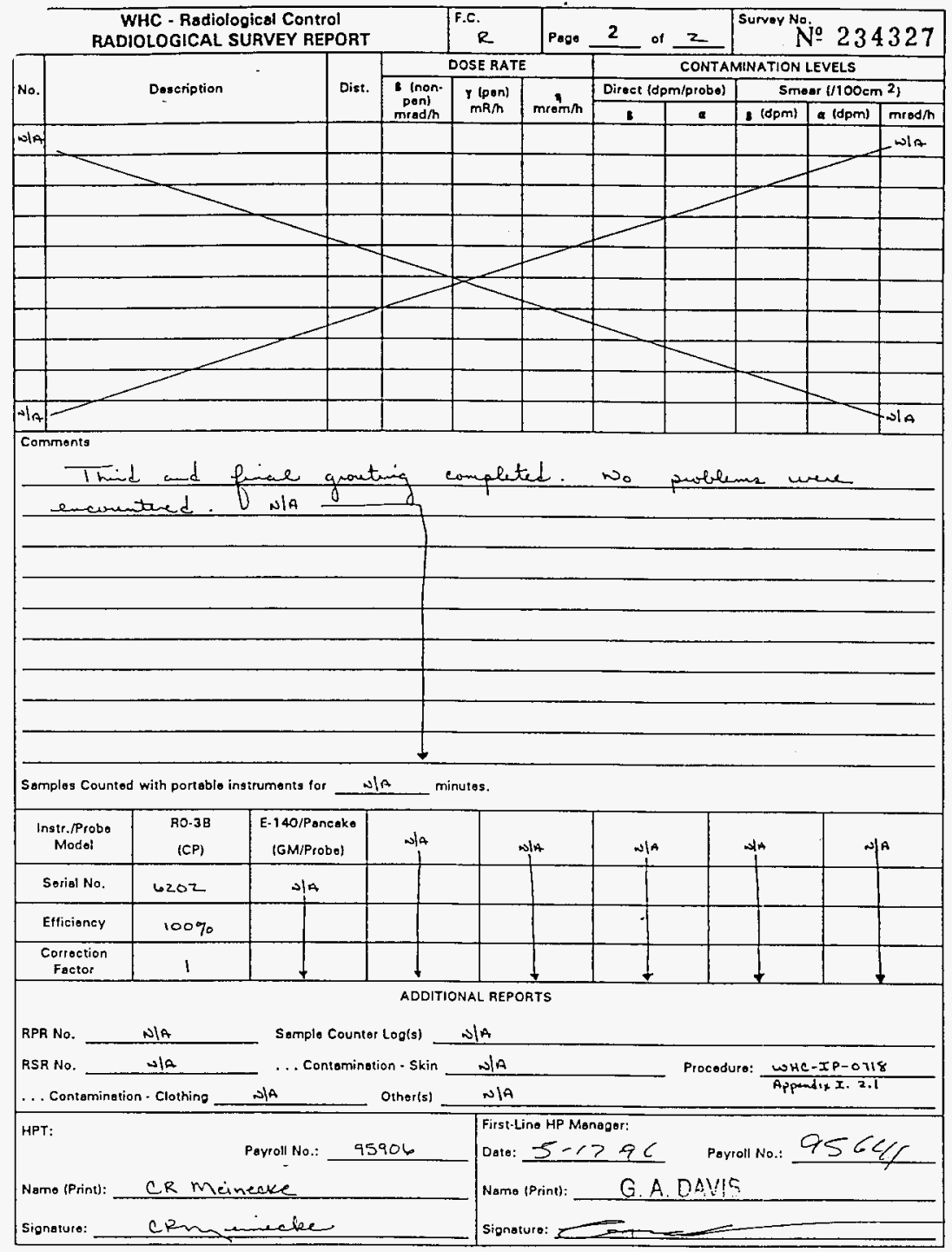




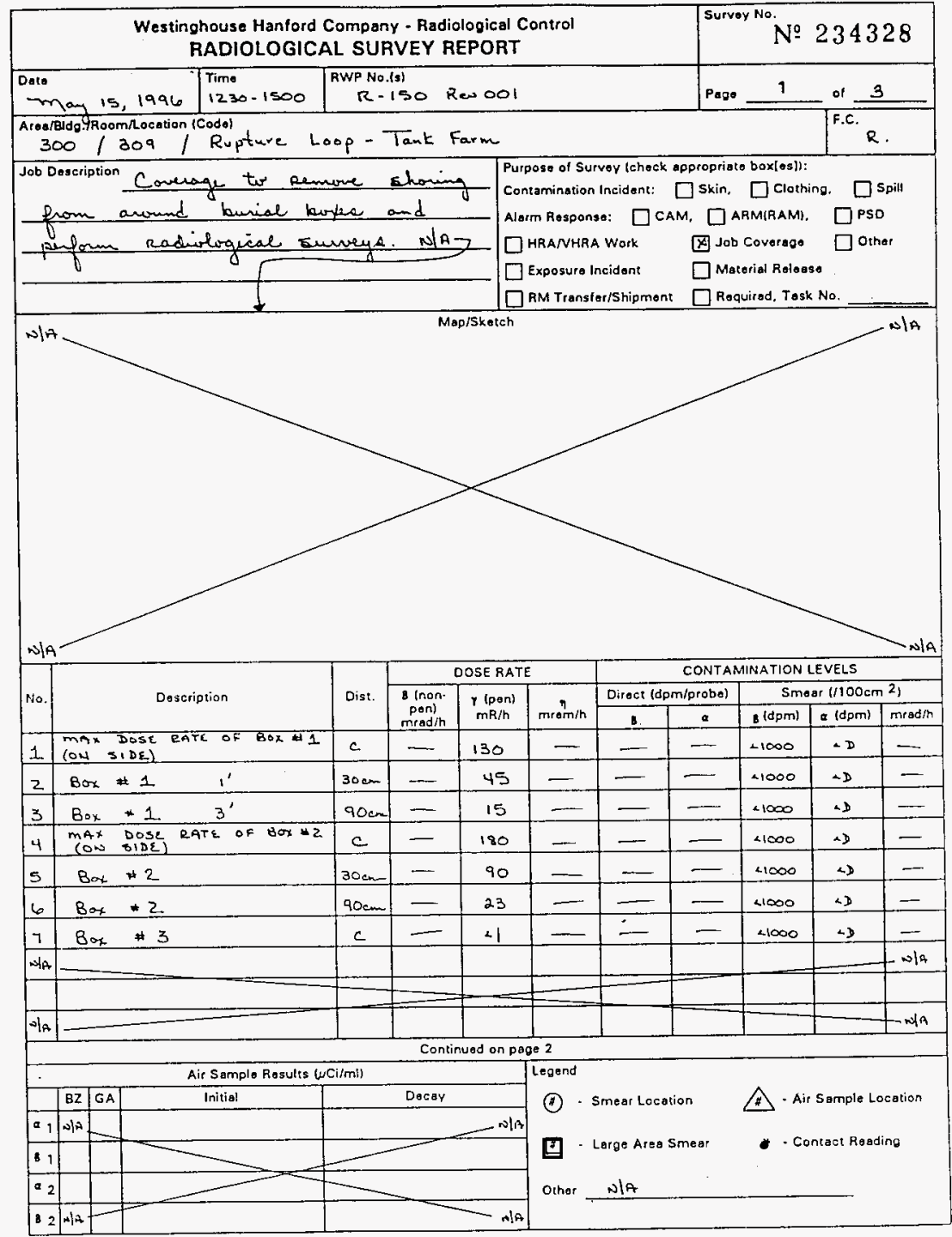

B0.6000.010(03/95) 


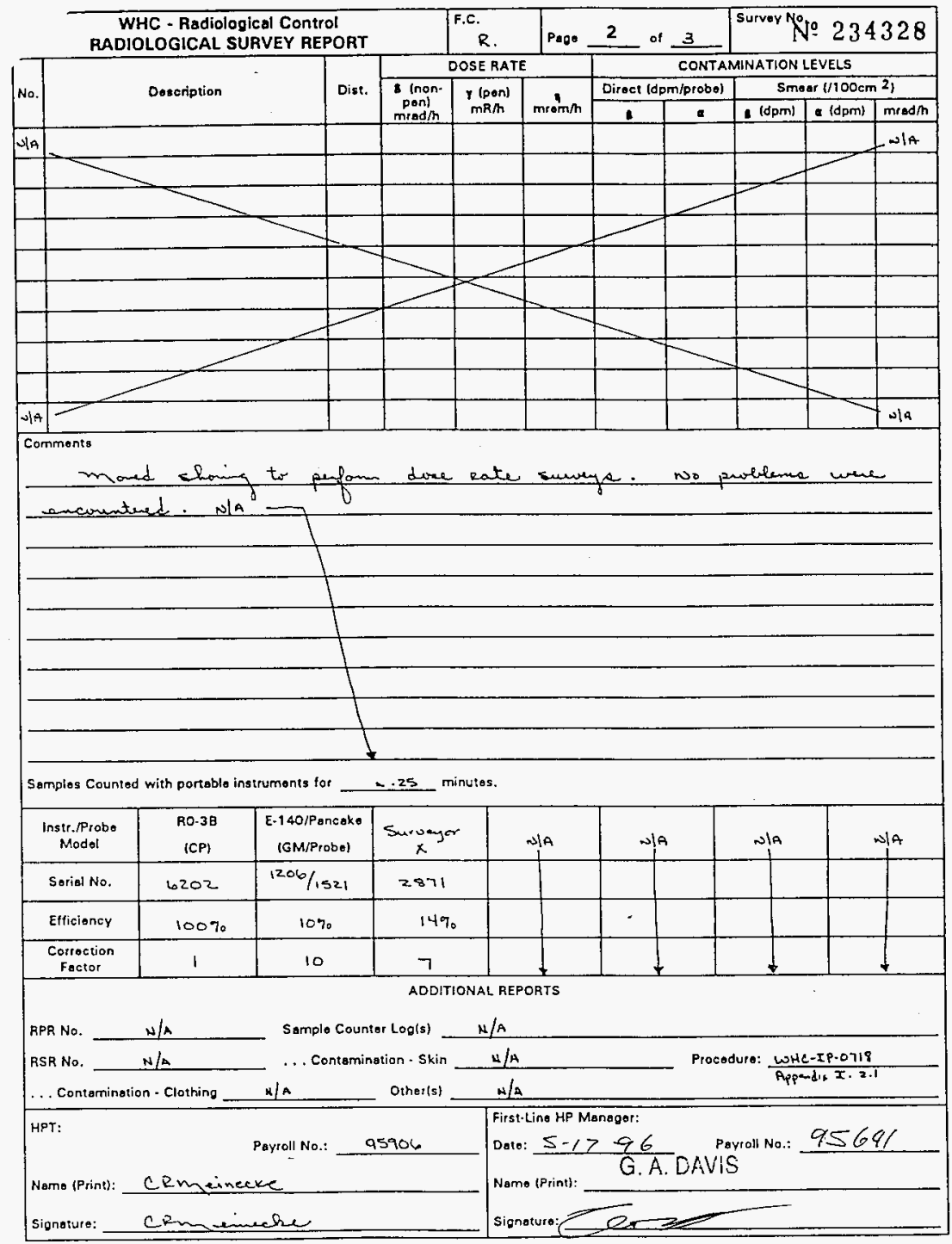




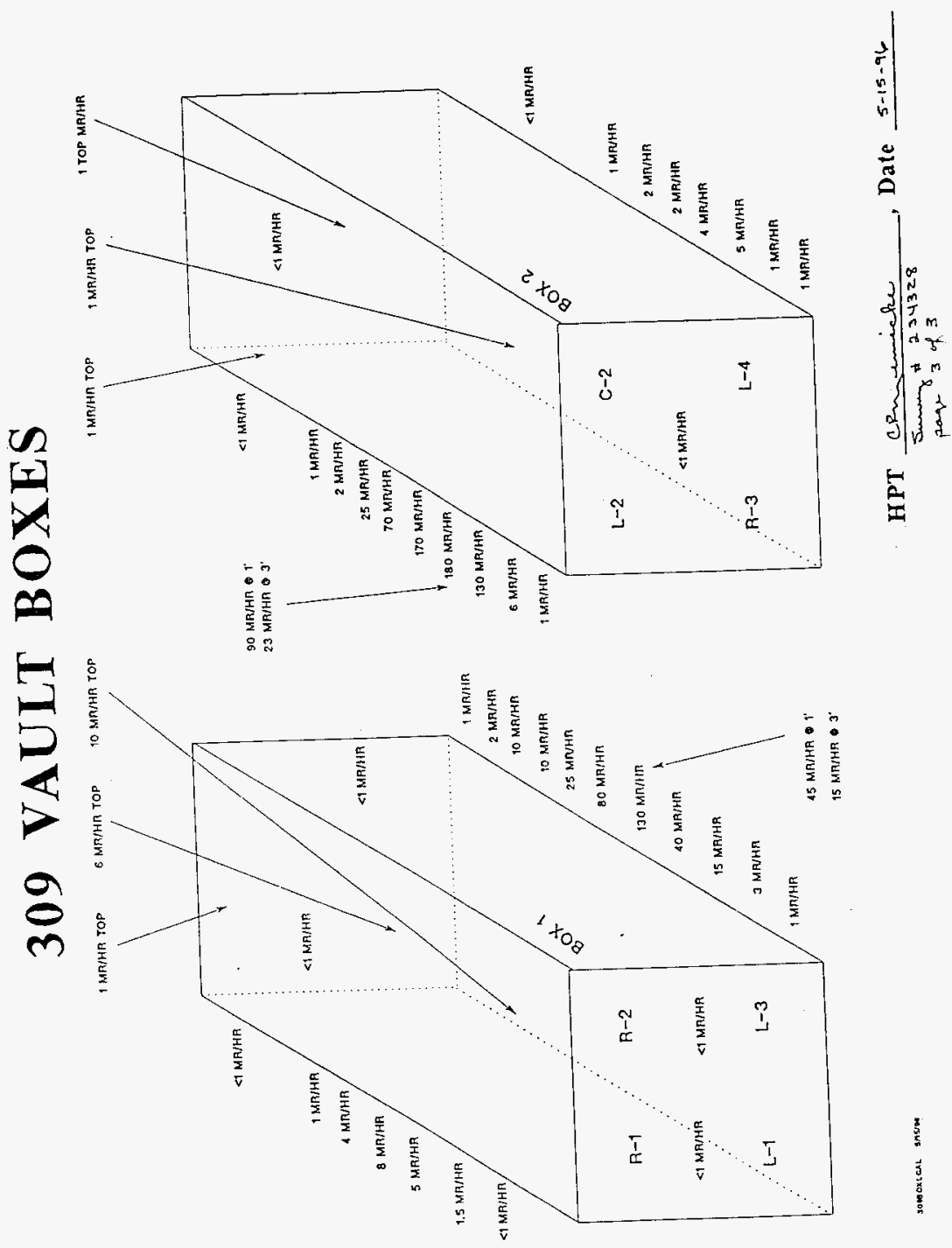


Information Only

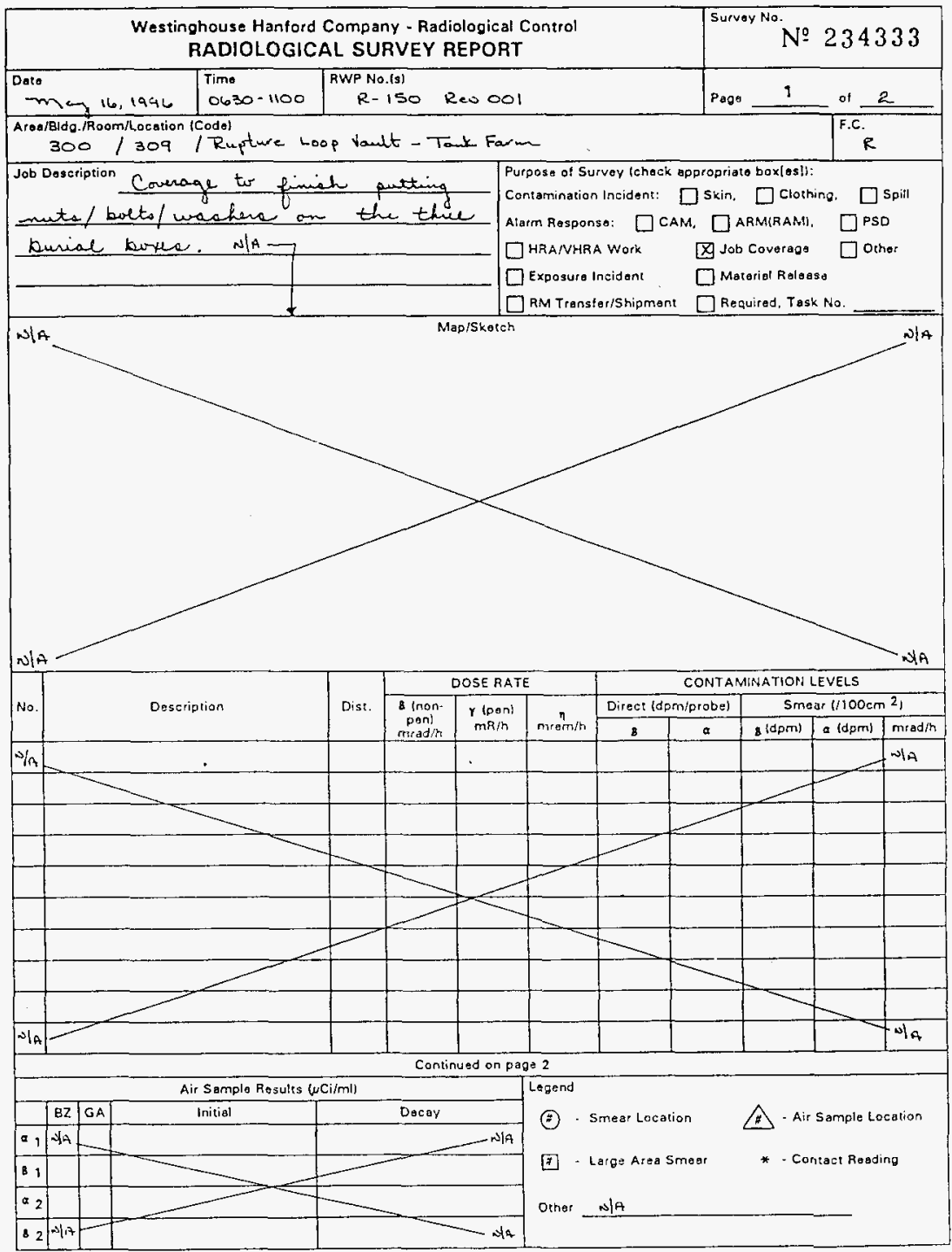




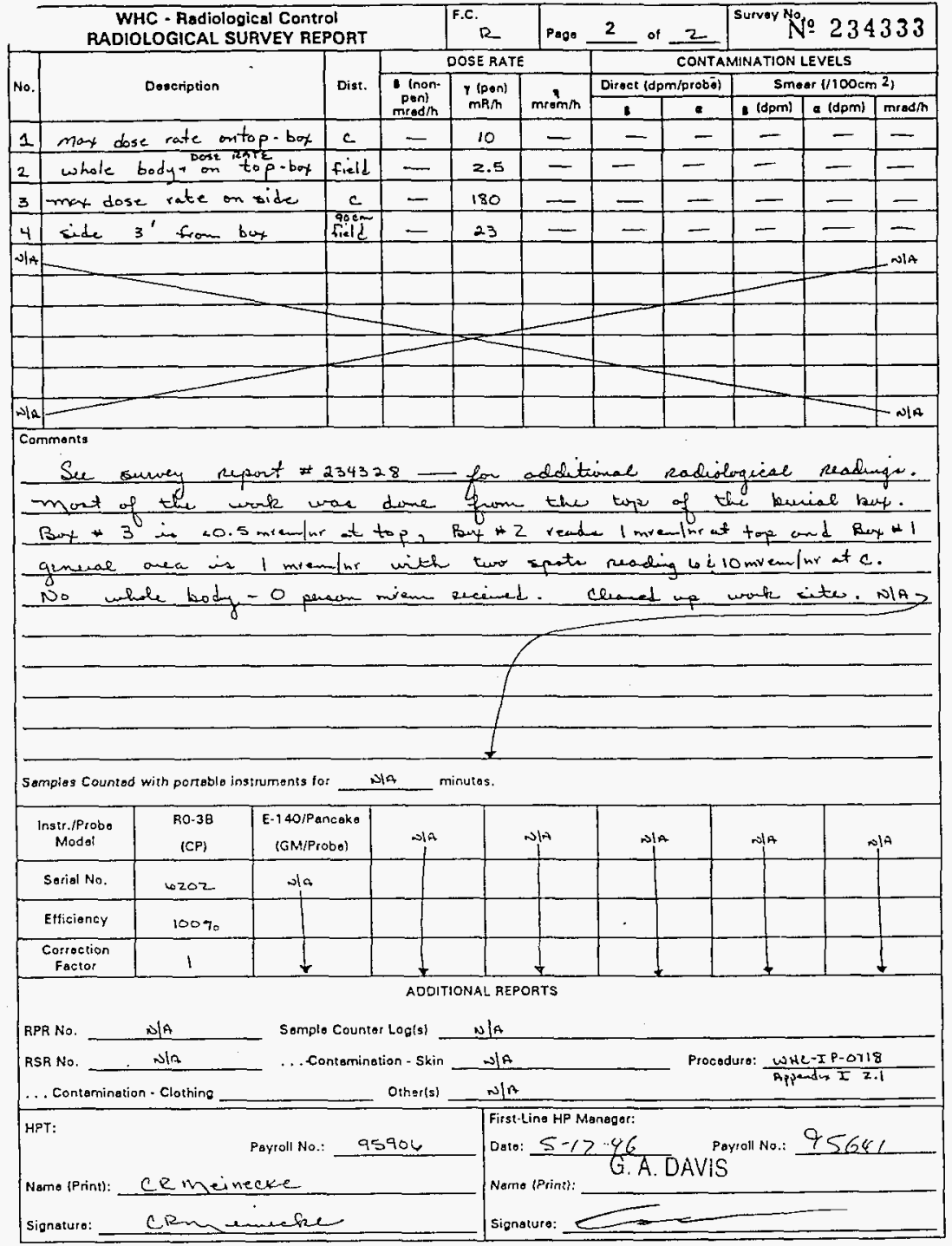




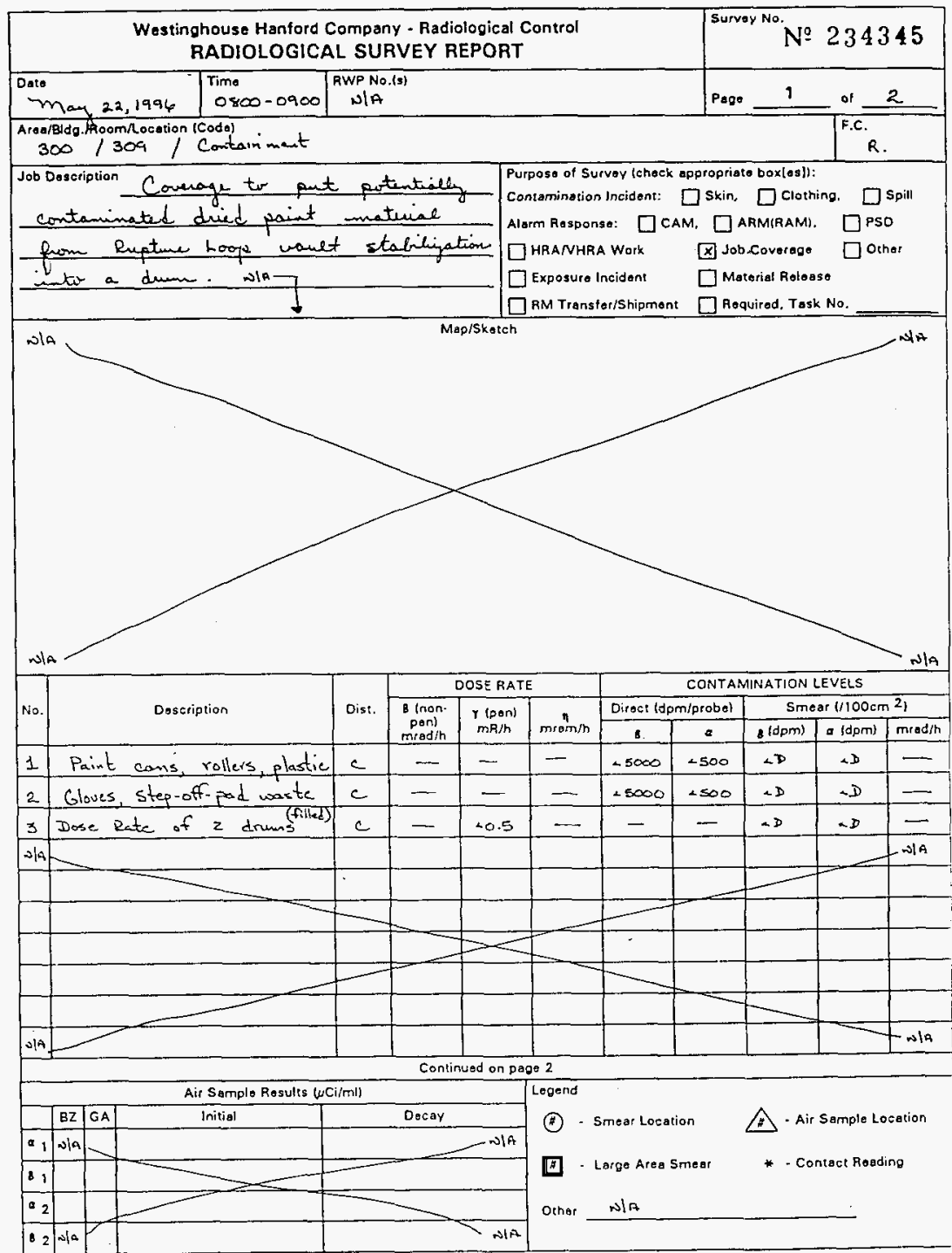

$80.6000-010(03 / 95)$ 


\section{WHC-SD-NEL-ER-004 Rev. 0}

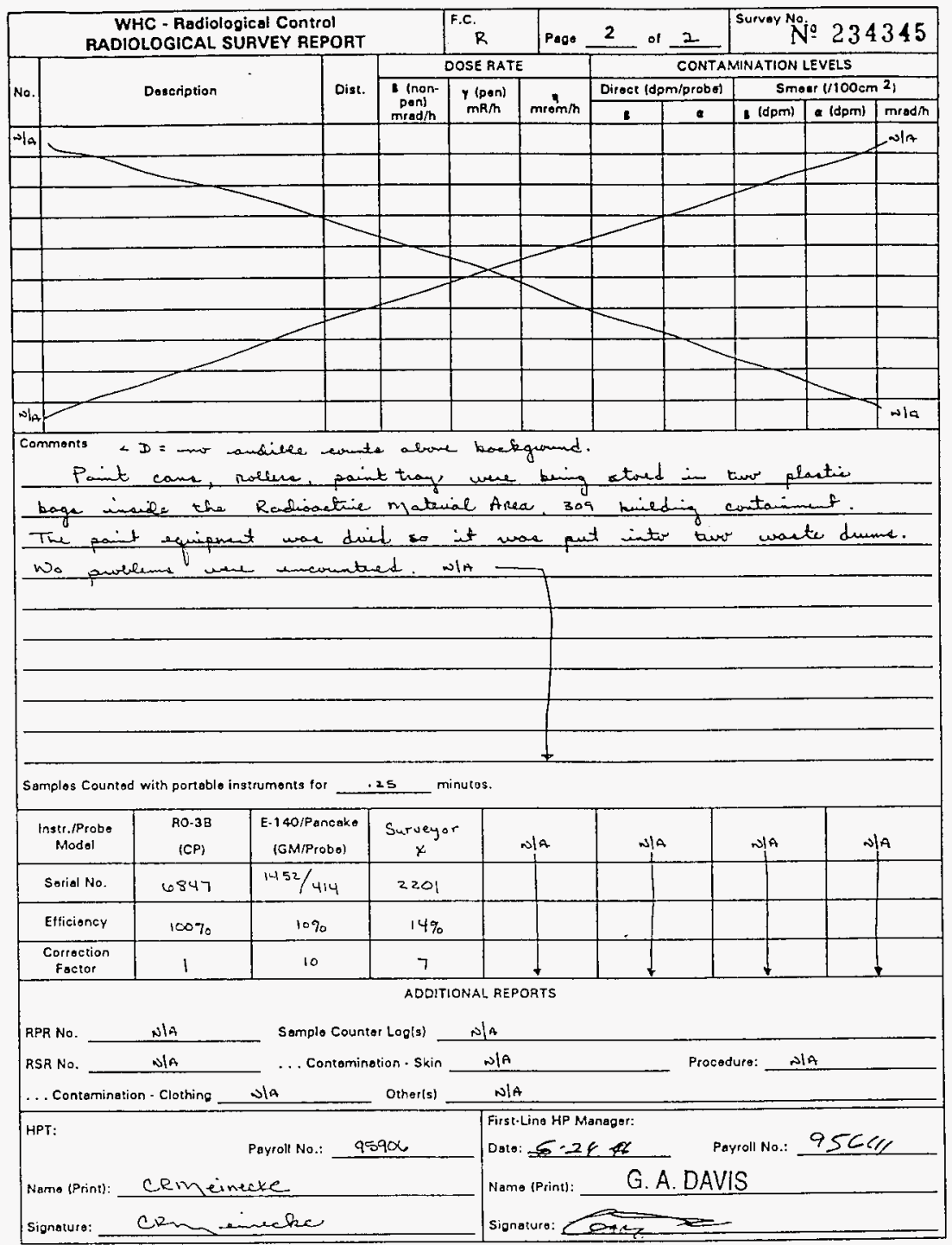




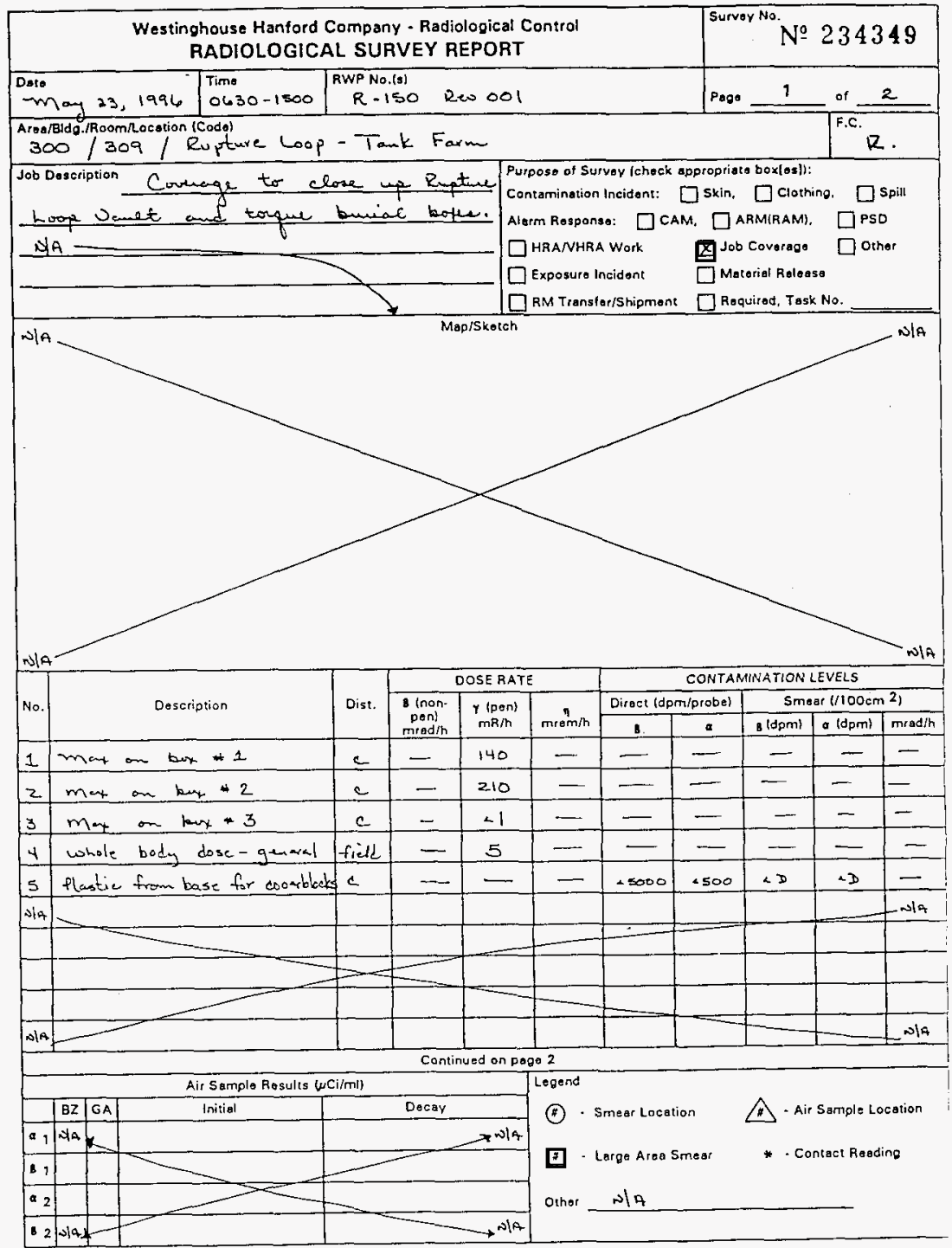




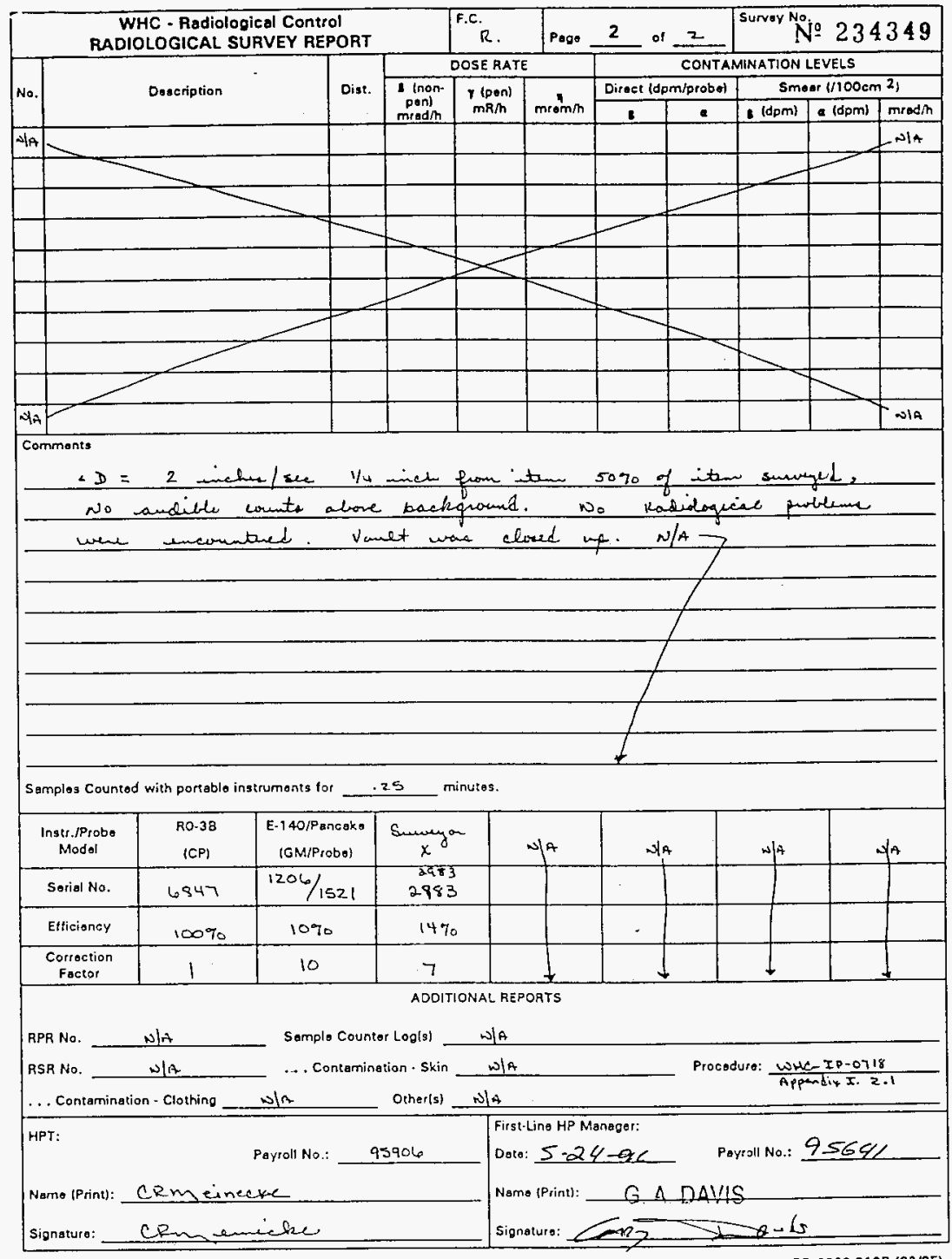




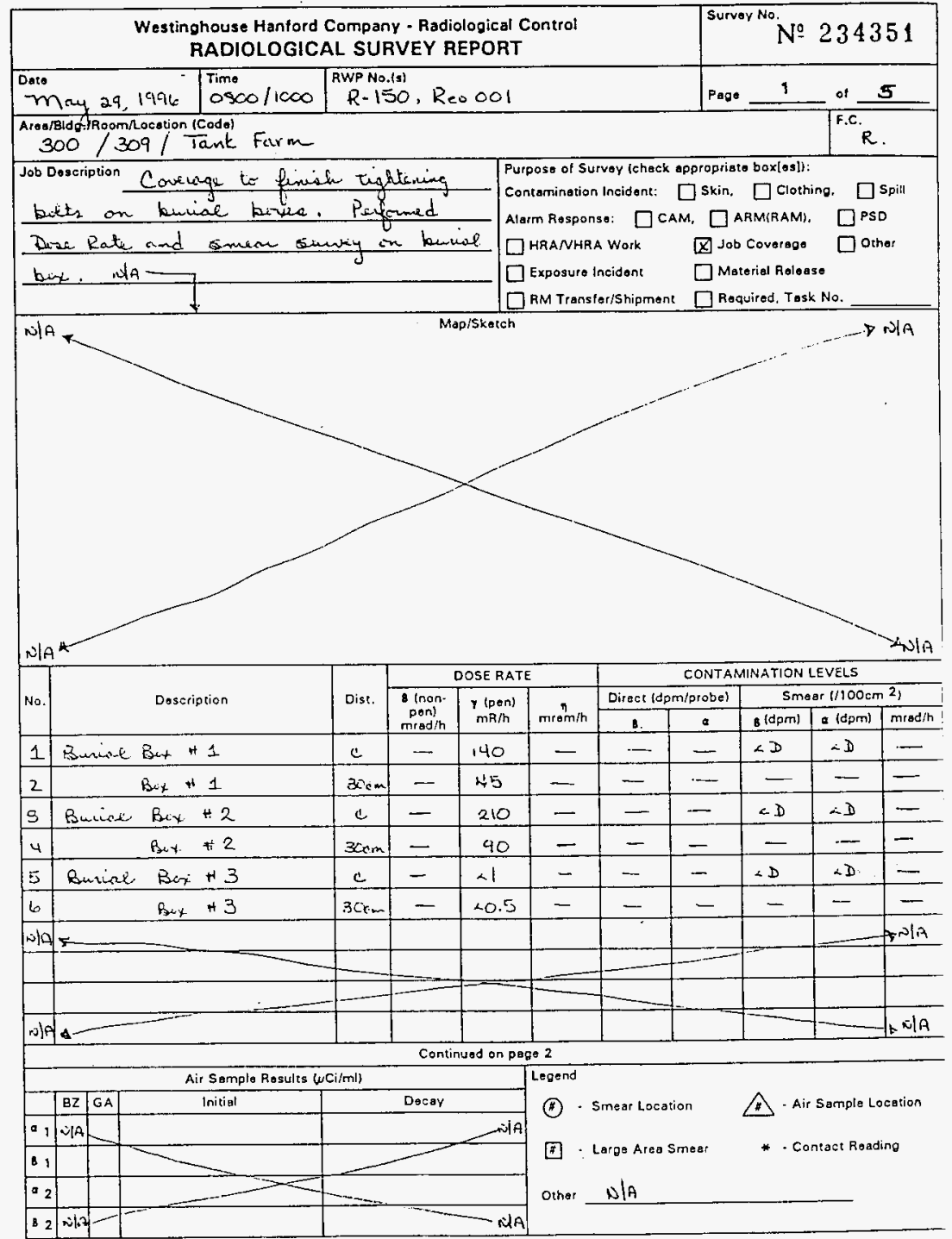




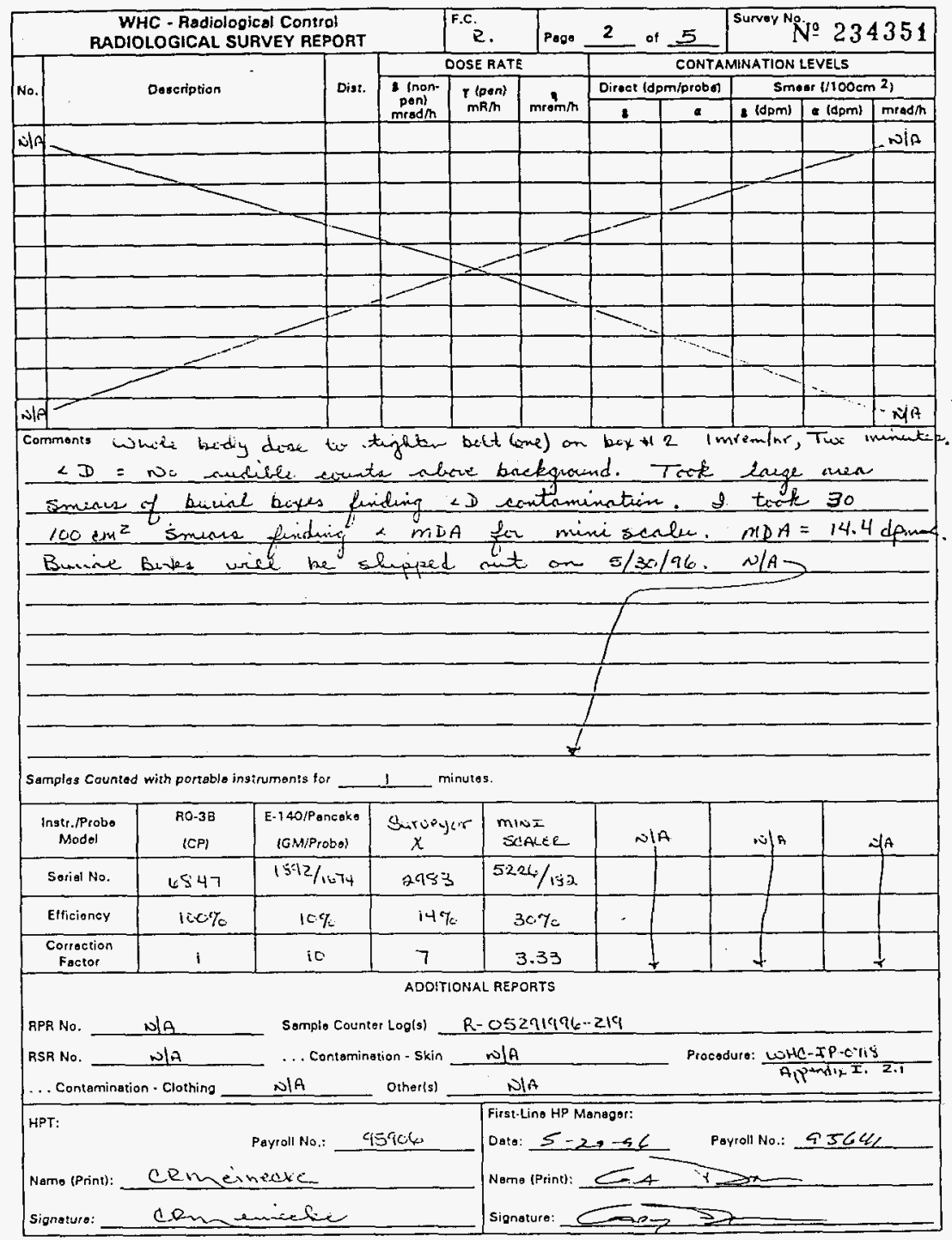




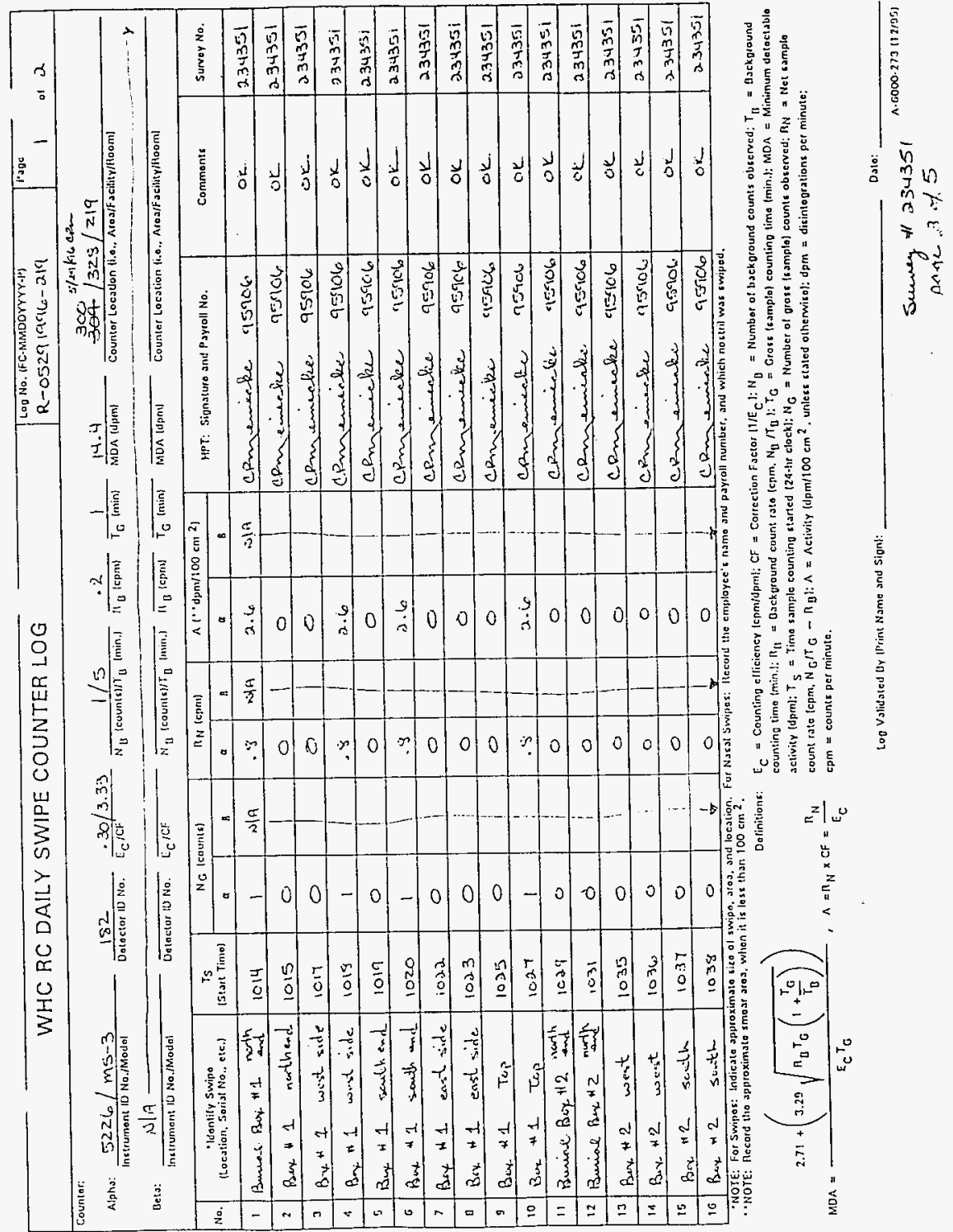




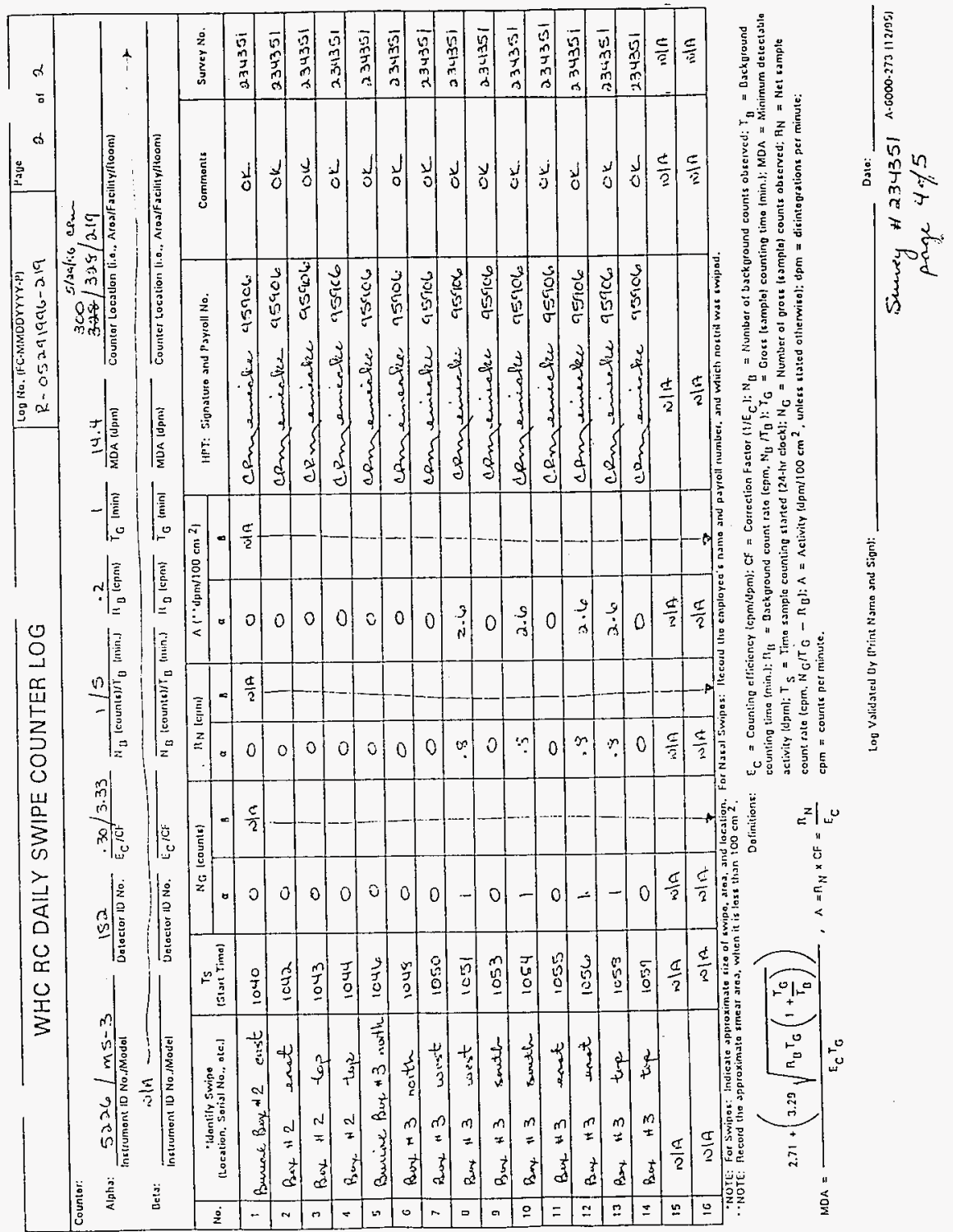



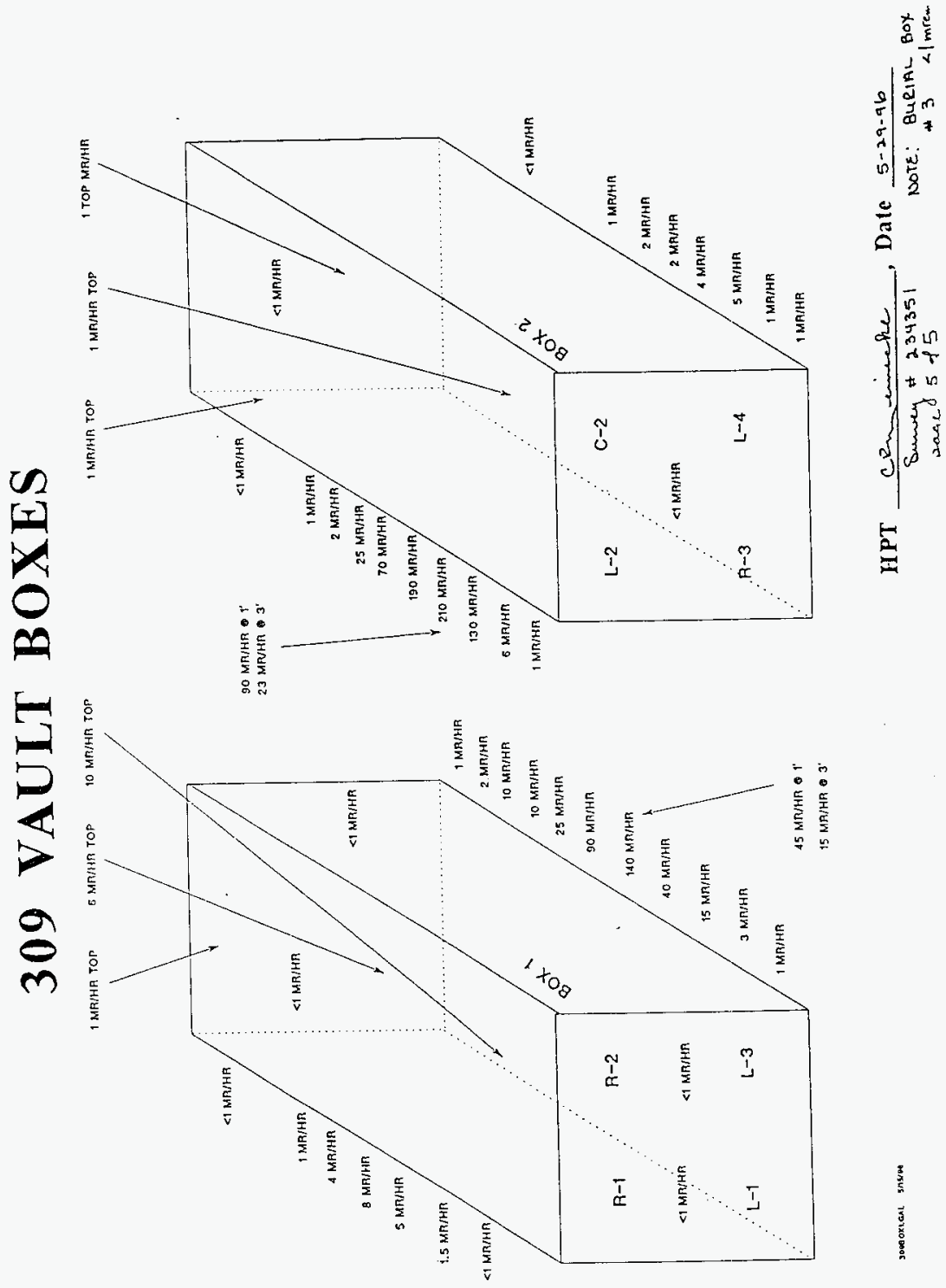

氙 


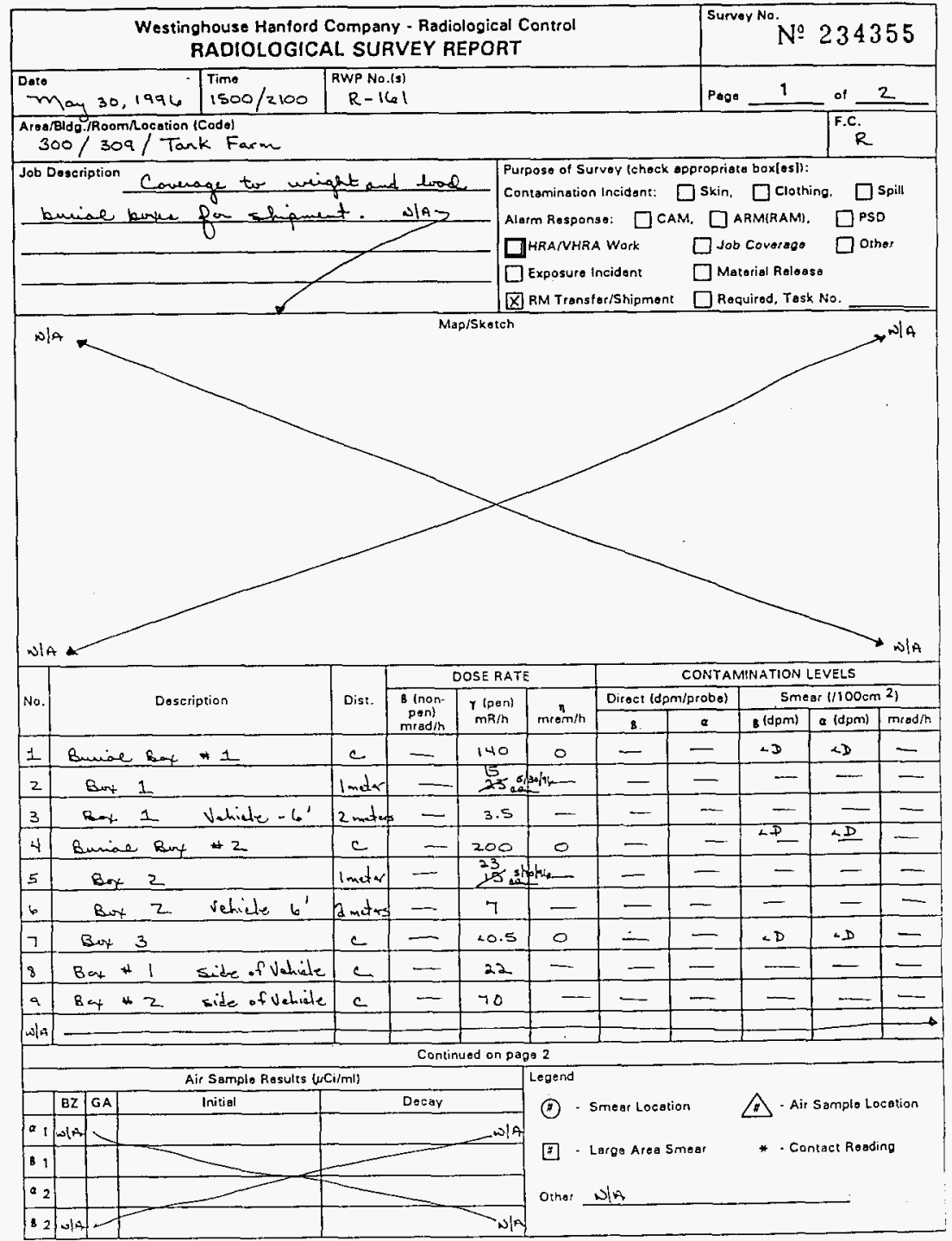




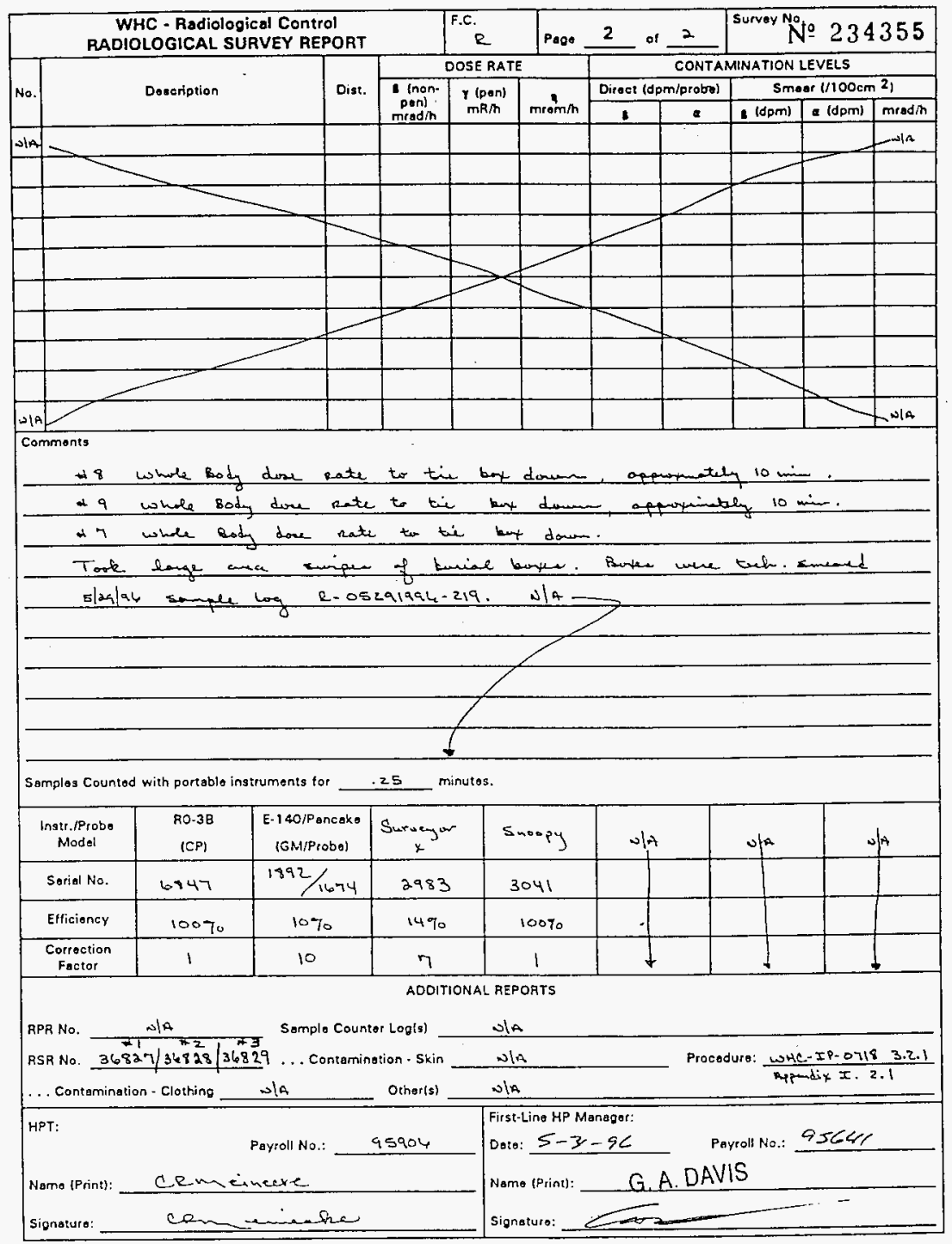




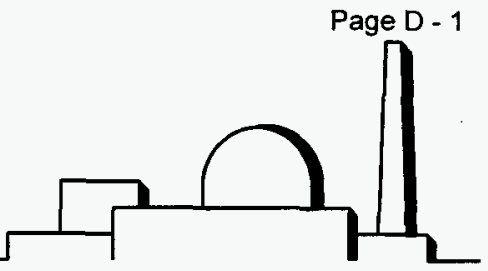

\section{APPENDIX D - FINAL WASTE CHARACTERIZATION}


TABLE OF CONTENTS

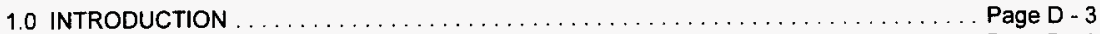

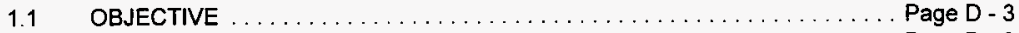

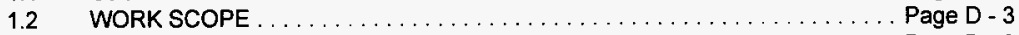

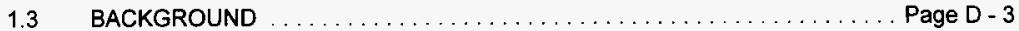

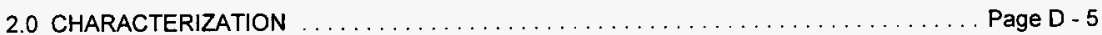

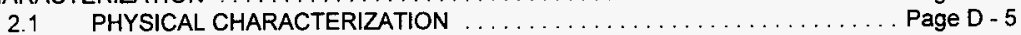

2.2 RADIOLOGICAL CHARACTERIZATION $\ldots \ldots \ldots \ldots \ldots \ldots \ldots \ldots \ldots$ Page D -5

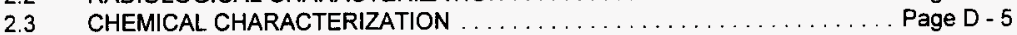

3.0 SEGREGATION AND PACKAGING $\ldots \ldots \ldots \ldots \ldots \ldots \ldots \ldots \ldots \ldots \ldots \ldots \ldots \ldots \ldots$

4.0 FINAL WASTE INVENTORY $\ldots \ldots \ldots \ldots \ldots \ldots \ldots \ldots \ldots \ldots \ldots \ldots \ldots \ldots \ldots \ldots \ldots \ldots \ldots \ldots$

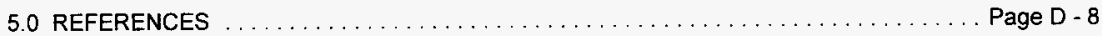

\section{ATTACHMENTS}

ATTACHMENT I: Physical Characterization $\ldots \ldots \ldots \ldots \ldots \ldots \ldots \ldots \ldots \ldots \ldots \ldots \ldots$ Page D -9

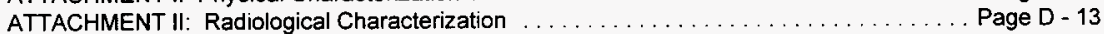

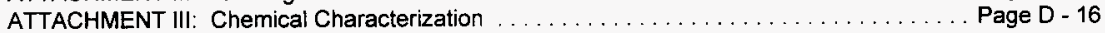

\section{TABLES}

Table 1 Characterization Summary

Page D - 4

Table 2 Final Waste Inventory Summary

Page D - 7

\section{ACRONYMS AND ABBREVIATIONS}

$\begin{array}{ll}\text { FERTF } & \text { Fuel Elements Rupture Test Facility } \\ \mathrm{g} & \text { grams } \\ \mathrm{IX} & \text { ion exchange } \\ \mathrm{kg} & \text { kilograms } \\ \mathrm{MSDS} & \text { material safety data sheet } \\ \mathrm{nCl} & \text { nano-curies } \\ \mathrm{NDA} & \text { nondestructive assay } \\ \mathrm{NDE} & \text { nondestructive examination } \\ \text { PNNL } & \text { Pacific Northwest National Laboratory } \\ \text { PRTR } & \text { Plutonium Recycle Test Facility } \\ \text { RLAIX } & \text { Rupture Loop Annex lon Exchange } \\ \text { TRU } & \text { transuranic (waste) }\end{array}$




\subsection{INTRODUCTION}

\subsection{OBJECTIVE}

This report provides documentation for the final characterization, packaging, and disposal of waste generated as a result of the cleanup activity in the Rupture Loop Annex lon Exchange (RLAIX) vault.

\subsection{WORK SCOPE}

The work scope involved packaging, shipping, and disposal of all waste generated during RLAIX vault cleanup.

\subsection{BACKGROUND}

The 309 Plutonium Recycle Test Reactor (PRTR) used a contained system for testing called Fuel Element Rupture Test Facility (FERTF). The FERTF was a pressurized, light-water-cooled loop, which used one of the 85 process tubes within the main, heavy-water-cooled PRTR calandria. It could be operated in a recirculating or once through cooling mode. The FERTF was a pilot irradiation facility to test new fuel element designs and new operating regimes. Many of its tests involved testing of pre-defective fuel elements, containing natural uranium and $1 \%$ to $4 \% \mathrm{PuO}_{2}$ (plutonium oxide), with pinhole breaks to study the stability of various defected material under irradiation. The RLAIX vault design had positions for three active ion exchange (IX) columns and storage space for 12 spent IX columns. The operating IX columns were connected in series for removal of the fuel and fission products in the FERTF coolant.

The RLAIX cleanup test loop and the PRTR main cleanup system were both contaminated with fuel residual and fission products. This contamination was filtered out of the system using the IX columns. Sample results from the PRTR IX columns resin indicated that the contents are not hazardous. Similar radiological contents are expected since the cleanup system IX columns in both vaults have similar resin media.

Entry and characterization were performed as documented in WHC-SD-NEL-ER-002, RLA lon Exchange Vault Entry and Characterization. Table 1 summarizes the results of that report, as well as final characterization that occurred subsequent to the report. 


\begin{tabular}{|c|c|c|c|c|c|c|c|c|}
\hline Item & $\begin{array}{l}\text { IX Weight: } \\
\text { Design Empty } \\
\text { Actual (kg) }\end{array}$ & $\begin{array}{l}\text { Peak Dose } \\
\text { Rate } \\
(\mathrm{mR} / \mathrm{hr})\end{array}$ & Resin? & Liquid? & $\begin{array}{l}\text { TRU } \\
\text { Waste? }\end{array}$ & $\begin{array}{l}\text { Low-Level } \\
\text { Waste? }\end{array}$ & $\begin{array}{l}\text { Dangerous } \\
\text { Waste? }\end{array}$ & Notes \\
\hline $\mid \times \mathbf{R} 1$ & - & 15 & YES & YES & NO & YES & NO & 3 \\
\hline $\mathrm{t} \times \mathrm{R} 2$ & - & 100 & YES & YES & NO & YES & NO & 3 \\
\hline IX R3 & - & 1,300 & YES & YES & NO & YES & NO & $2,3,4$ \\
\hline IX R4 & - & 35 & YES & NO & NO & YES & NO & 3,6 \\
\hline $\begin{array}{l}\text { IX R5/ } \\
\text { RLIX-1 }\end{array}$ & - & 2 & YES & YES & NO & YES & NO & 3 \\
\hline IX L1 & - & 5 & YES & YES & NO & YES & NO & 3 \\
\hline $1 \times L 2$ & - & 35 & YES & YES & NO & YES & NO & 3 \\
\hline IX L3 & . & 2,500 & YES & YES & NO & YES & NO & $2,3,4$ \\
\hline IX L4 & - & 30 & YES & NO & NO & YES & No & $2,3,4,6$ \\
\hline $\mathrm{IXC2}$ & - & 35 & YES & NO & NO & YES & No & $2,3,4,6$ \\
\hline $\mathrm{IXC3}$ & $227 / 240$ & 2 & NO & NO & No & YES & NO & $1,3,5,7$ \\
\hline IX C4 & $82 / 82$ & 3 & NO & NO & NO & YES & NO & $1,3,5,7$ \\
\hline $\begin{array}{l}\text { Filter } \\
\text { Assembly } \\
\text { and } \\
\text { Debris }\end{array}$ & . & bckgrnd & NO & $?$ & No & YES & NO & \\
\hline
\end{tabular}

(1) The estimated design weight without resin of the $\mathrm{IX}$ is based upon $\mathrm{H}-3$ drawings (Attachment I).

(2) Uncertainty total for transuranic (TRU) waste is based on the square root of the sum of the squares of individual uncertainties.

(3) Due to the similarity of the RLAIX Vault and the PRTR IX Vault's resin type, cleanup process, and common accidental test failure, it has been concluded that the data presented in WHC-SD-NELER-002 for the PRTR IX columns sample analysis is a valid source in the determination that the RLAIX column contents would not be regulated as dangerous waste.

(4) The IX column contains less than $100 \mathrm{nCi}$-alpha/g TRU material, therefore it is not TRU waste, but is designated as low-level waste.

(5) Based upon the process knowledge that the IX column was not used along with the fact that the estimated design weight and actual weight of the IX column are approximately the same, the IX column is empty of resin and liquid.

(6) Based upon nondestructive examination (NDE), the $I X$ is empty of liquid.

(7) When columns $\mathrm{C} 3$ and $\mathrm{C} 4$ were moved to different positions away from columns L3, R3, and L4, $\mathrm{C} 4$ was recounted and shown to have no TRU. This is contrary to the initial count done when the IX columns were in their original positions. The initial count is contributed to shine from columns $\mathrm{R} 3, \mathrm{~L} 3$, and $\mathrm{L} 4$. The dose rates of columns $\mathrm{C} 3$ and $\mathrm{C} 4$ dropped to background levels after moving them to the new positions in the RLAIX vault. Based upon this and the fact that columns C3 and $\mathrm{C} 4$ were shown to be empty, columns $\mathrm{C} 3$ and $\mathrm{C} 4$ have no TRU. 


\subsection{CHARACTERIZATION}

\subsection{PHYSICAL CHARACTERIZATION}

The waste that was removed from the RLAIX vault consisted of 12 IX columns ( 10 of which contained resin); piping, connector heads, jumpers, valving, metal blow down filter, other metal debris, wood, plastic, rubber, and sweepings off of the floor of the RLAIX vault (dirt, rust, scrap material); equipment used to pump liquids from the $\mathrm{IX}$ columns; small quantities of inorganic, nonregulated absorbed liquids; and other non-regulated materials. Metal materials are made of aluminum, carbon steel, and stainless steel. Attachment I provides additional physical characterization information.

\subsection{RADIOLOGICAL CHARACTERIZATION}

The IX columns received a Gamma analysis with results showing ${ }^{60} \mathrm{Co}$ (cobalt), ${ }^{137} \mathrm{Cs}$ (cesium), ${ }^{90} \mathrm{Sr}$ (strontium). The value for ${ }^{90} \mathrm{Sr}$ was derived from a ratio of ${ }^{90} \mathrm{Sr}$ to ${ }^{137} \mathrm{Cs}$ based on laboratory analysis of PRTR IX columns. The TRU distribution was a result of a Pacific Northwest National Laboratory (PNNL) assay and the decay calculations from the documented original fuel burn in the reactor (WHC-SD-NELER-002). The resulting isotopic distributions consisted of ${ }^{241} \mathrm{Am}$ (americium), ${ }^{237} \mathrm{~Np}$ (neptunium), ${ }^{233} \mathrm{~Pa}$ (protactinium), ${ }^{234} \mathrm{U}$ (uranium), ${ }^{235} \mathrm{U},{ }^{236} \mathrm{U},{ }^{238} \mathrm{U},{ }^{238} \mathrm{Pu}$ (plutonium), ${ }^{239} \mathrm{Pu},{ }^{240} \mathrm{Pu},{ }^{241} \mathrm{Pu}$, and ${ }^{242} \mathrm{Pu}$. This is an industrial standard method for isotopic distribution. Attachment II provides additional radiological characterization information.

The IX columns were segregated into three waste container boxes and the curies were totaled for the point source and category calculations. Refer to Attachment II for radiological waste category calculations, per WHC-EP-0063-4, Hanford Site Solid Waste Acceptance Criteria. Four IX columns were placed in each $12.23 \mathrm{~m}^{3}\left(432 \mathrm{ft}^{3}\right)$ [1.83m $\left.\times 1.83 \mathrm{~m} \times 3.66 \mathrm{~m}\left(6^{\prime} \times 6^{\prime} \times 11^{\prime}\right)\right]$ waste container box. Waste container boxes \#1 and \#2 were category III and waste container box \#3 was category I. Box \#1 contained IX columns L1, L3, R1, and R2 (category III). Box \#2 contained IX columns L2, L4, C2, and R3 (category III). Box \#3 contained IX columns C3, C4, R4, R5/RLIX-1, and other debris taken from the RLAIX Vault (category I). All waste added to box \#3 that was not an IX column contained less than $1 \%$ of the IX columns activity and therefore, had no activity contribution to the waste container box.

\subsection{CHEMICAL CHARACTERIZATION}

The cation RLAIX column (RLIX-1) contained an AMBERLITE ${ }^{\$ R N}-163$ resin. The mixed bed RLAIX column (RLIX-2) contained an AMBERLITE ${ }^{\circledR}$ IRN-154 resin, which is a combination of AMBERLITE ${ }^{\circledR}$ IRN163 and AMBERLITE ${ }^{\oplus}$ IRN-78 resins. The de-oxygenator (RLIX-3) contained a Duolite S-10 and AMBERLITE ${ }^{\circledast}$ IRN-154 mixture. These resins are not regulated as dangerous waste. Analysis from the PRTR IX column resins was used as historical knowledge for the RLAIX columns due to the similarity of the resins, water process, and common accidental test failure of the total system. Supporting document WHC-SD-NEL-ER-002 contains PRTR resin material safety data sheets (MSDS) and PRTR resin analysis results. The analysis that was performed on the PRTR IX column resins and shown to be non-hazardous, was used to designate the RLAIX resins as non-hazardous. The final waste designation per WAC 173303 is shown in Attachment III.

AMBERLITE is a trademark of Rohm and Haas Company or one of its subsidiaries or affiliates. 


\subsection{SEGREGATION AND PACKAGING}

Segregation of the waste into the proper containers was performed using work procedure 309-WP-96-002, Rupture Loop Annex Ion Exchange (RLAIX) Vault Cleanout. This procedure also ensured the packaging requirements were met.

The $I X$ columns were packaged in three Type A metal boxes. The reference for the packaging is WHC. SD-TP-SEP-047, Safety Evaluation for Packaging for Onsite Transfer of 12 lon Exchange Columns.

The waste, as packaged, was classified as low-level waste. The IX columns placed in waste container boxes \#1 and \#2 were stabilized with grout to meet the requirements for category III waste disposal. The grout formulation was grout mix number 4 as required by internal memo sent from $B$. A. Mayancsik to $E$. $J$. Bitten, "Plutonium Recycle Test Facility Ion Exchange Columns Stabilization," dated May 6, 1996. It was not necessary to stabilize waste container box \#3, since it was category I waste. However, the grout was used in the same manner in waste container box \#3 to meet void space requirements.

The IX columns had as much liquid removed as was reasonably achievable using a peristaltic pump. The only $\mathrm{IX}$ columns that would have had liquid remaining after pumping were the $\mathrm{IX}$ columns with spargers. Based on process knowledge, the maximum free liquid that would have remained in a given sparger IX column is 26.5 liters ( 7 gallons). Polymeric sorbent (RADSORB) was added to all of the IX columns in sufficient amounts to sorb 53 liters ( 14 gallons) of liquid. The IX columns were then oriented horizontally to allow all the liquid to drain into the sorbent.

Plastic liners were not used to line the boxes. All waste in waste container boxes \#1, \#2, and \#3 were encased in at least $5.08 \mathrm{~cm}(2 ")$ of grout between the waste and the inner surface of each box to provide one containment barrier. The waste container box itself served as the other containment barrier.

The maximum free void space in each IX column that contained resin was $0.13 \mathrm{~m}^{3}\left(4.56 \mathrm{ft}^{3}\right)$, based on process knowledge. This calculates to be a total free void space in each $12.23 \mathrm{~m}^{3}\left(432 \mathrm{ft}^{3}\right)$ waste container box of $4.22 \%$. This is below the maximum free void space limit of $10 \%$ set by WHC-EP-0063-4. Since the resin chambers in IX columns $\mathrm{C} 3$ and $\mathrm{C} 4$ were empty of resin, the void spaces were also filled with the same grout used in the waste container boxes.

All waste in waste container boxes \#1 and \#2 were encased in at least $5.08 \mathrm{~cm}(2 ")$ of grout to meet stabilization requirements. Grout was not required for stabilization in waste container box \#3. There was no aluminum in contact with the grout in waste container boxes \#1 and \#2. Column C4 was the only IX column made of aluminum or with aluminum dunnage, thus, column $\mathrm{C} 4$, located in waste container box \#3, was in contact with grout.

Waste container boxes \#1 and \#2 allowed for the off-gassing of hydrogen that is generated in the IX columns. The fill pipe of each $\mathrm{IX}$ column was not hermetically sealed. The grout and the Type $A$ box will allow the diffusion of the hydrogen, thus, gas pressurization problems will be nonexistent. 


\subsection{FINAL WASTE INVENTORY}

The total waste that was generated as a result of this cleanup operation is documented in Table 2 below.

\begin{tabular}{|c|c|c|}
\hline Waste & Amount & $\begin{array}{l}\text { Treatment, Storage, Disposal } \\
\text { Facility }\end{array}$ \\
\hline $\begin{array}{l}\text { IX Column Category } 3 \text { Low-Level } \\
\text { Waste }\end{array}$ & $\begin{array}{l}\text { Two } 1.8 \mathrm{~m} \times 1.8 \mathrm{~m} \times 3.6 \mathrm{~m}\left(6^{\prime} \times 6^{\prime} \times 12^{\prime}\right) \\
\text { boxes. }\end{array}$ & $\begin{array}{l}\text { Hanford Site Low-Level Burial Grounds } \\
\text { for disposal. }\end{array}$ \\
\hline $\begin{array}{l}\text { IX Column and Vault Debris Category } 1 \\
\text { Low-Level Waste }\end{array}$ & $\begin{array}{l}\text { One } 1.8 \mathrm{~m} \times 1.8 \mathrm{~m} \times 3.6 \mathrm{~m}\left(6^{\prime} \times 6^{\prime} \times 12^{\prime}\right) \\
\text { box. }\end{array}$ & $\begin{array}{l}\text { Hanford Site Low-Level Burial Grounds } \\
\text { for disposal. }\end{array}$ \\
\hline $\begin{array}{l}\text { Additional Low-Level Debris from } \\
\text { Cleanup Operation }\end{array}$ & Two 208 liter (55 gallon) drums. & $\begin{array}{l}\text { Accumulated with other } 309 \text { facility } \\
\text { step-off pad waste. }\end{array}$ \\
\hline $\begin{array}{l}\text { Radiologically Contaminated Water } \\
\text { from } \mathrm{X} \text { Columns }\end{array}$ & Fourteen 208 liter (55 gation) drums. & 340 Facility for storage. \\
\hline $\begin{array}{l}\text { Empty Liquid Drums used in PRTR and } \\
\text { RLAIX Vault cleanup operations. }\end{array}$ & $\begin{array}{l}\text { Twenty-One empty } 208 \text { liter ( } 55 \text { gallon) } \\
\text { drums. }\end{array}$ & $\begin{array}{l}\text { ATG for size reduction. } \\
\text { Hanford Site Low-Level Burial Grounds } \\
\text { for disposal. }\end{array}$ \\
\hline
\end{tabular}




\subsection{REFERENCES}

Ham, J.E., 1995, RLA lon Exchange Vault Entry and Characterization, WHC-SD-NEL-ER-002, Rev. 0, Westinghouse Hanford Company, Richland, Washington.

Mayancsik, B. A., 1996, internal memo sent to E. J. Bitten, "Plutonium Recycle Test Facility lon Exchange Columns Stabilization," May 6, 1996, Richland, Washington.

Mercado, M. S., 1996, Safety Evaluation for Packaging for Onsite Transfer of 12 lon Exchange Columns, WHC-SD-TP-SEP-047, Revision 0, Westinghouse Hanford Company, Richland, Washington.

PRTR Transition, 1996, Rupture Loop Annex Ion Exchange (RLAIX) Vault Cleanout, 309-WP-96-002, Revision 0 , Westinghouse Hanford Company, Richland, Washington.

WAC, 1995, Dangerous Waste Regulations, WAC 173-303, Washington Administrative Code, Washington D.C.

WHC, 1996, Hanford Site Solid Waste Acceptance Criteria, WHC-EP-0063-4, UC-721, Westinghouse Hanford Company, Richland, Washington. 


\section{ATTACHMENT I: Physical Characterization}




\section{RLAIX Vault Contents}

The items in the RLAIX Vault consist of three types of ion exchange columns that were used in the PRTR Rupture Loop, two types of ion exchange columns that were used in the PRTR Loop, as well as piping, connector heads, jumpers, valving, metal blow down filter, other metal debris, wood, plastic, rubber, and sweepings off the floor (dirt, rust, scrap material).

\section{Process}

The ion exchangers were designed to: (1) continuously purify coolant at $10-200 \mathrm{gpm}$ and remove oxygen from coolant at $10 \mathrm{gpm}$ operating in a recirculating mode; (2) remove radioactive materials from the entire coolant stream at $200 \mathrm{gpm}$ during intermittent 6 hour single pass operating periods during failed fuel experiments. Fuel was natural $\mathrm{U}$ with $2 \%$ or $4 \% \mathrm{PuO}_{2}$ (plutonium-oxide).

\section{Ion Exchangers}

Ion exchangers which were used in the RLAIX system included three units: a mixed bed exchanger, a cation exchanger, and a deoxygenating exchanger. The ion exchangers purified and deoxygenated water at a $\mathrm{pH}$ of 9-11. Ion exchange resins are in the $\mathrm{LiOH}$ form. These ion exchangers and resins are similar in function and use to those from the PRTR vault.

\section{MECHANICAL DATA REFERENCE INFORMATION}

\author{
RLIX-1 AND RLIX-2 \\ (latest: H-3-14005, reissue) \\ Cation and Mixed Bed \\ $\sim 3,800$ lbs (gross wt.) \\ $10^{\prime}-101 / 2 "$ Max. Height \\ Shell: \\ 2'4.75" O.D., 8'0" Long \\ $\sim 33 \mathrm{ft}^{3}$ Total Volume \\ Resin Chamber: \\ 4'2.5" Long, 28" I.D \\ volume $-18 \mathrm{ft}^{3}$ \\ Gravel Chamber: \\ 28.5" Long, 28" I.D. \\ volume $\sim 10 \mathrm{ft}^{3}$

\section{IX-1 AND IX-4 \\ $\sim 230$ lbs (empty wt.) \\ 9'10.5" Max. Height \\ Shell: \\ 2'6" O.D., 6'5" Long \\ $\sim 32 \mathrm{ft}^{3}$ Total Volume \\ Resin Chamber: \\ 4'11" Long $29.75^{\prime \prime}$ I.D. \\ volume $\sim 24 \mathrm{ft}^{3}$}

\author{
RLLIX-3 \\ Deoxygenator \\ $\sim 1,800$ lbs (gross wt.) \\ 11' Max. Height \\ Shell: \\ 1'9.75" O.D., 8'0" Long \\ $\sim 18 \mathrm{ft}^{3}$ Total Volume \\ Resin Chamber: \\ 6'6" Long, 21" I.D. \\ volume $\sim 16 \mathrm{ft}^{3}$
}

\author{
IX-2 AND IX-3 \\ $\sim 90$ lbs (empty wt.) \\ 9'10.5" Max. Height \\ Shell: \\ 1'6" O.D., 6'5" Long \\ $\sim 12 \mathrm{ft}^{3}$ Total Volume \\ Resin Chamber: \\ 5'6" Long, 17.5" I.D. \\ volume $-10 \mathrm{ft}^{3}$
}




\begin{tabular}{|c|c|}
\hline IX Column & Resin \\
\hline Cation & $\begin{array}{l}\text { AMBERLITE }{ }^{\star} \times E-163 \text { (AMBERLITE* IRN-163) } \\
\text { Sulfonated polystyrene/divinybenzene copolymer }\end{array}$ \\
\hline Mixed Bed & 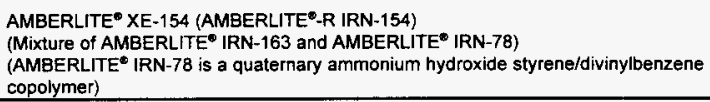 \\
\hline Deoxygenator & $\begin{array}{l}\text { AMBERLITE XE-154 } \\
\text { Duolite S-10 } \\
3 \text { to } 5 \text { Ratio } \\
\text { Duolite S-10 is either a phenol/formaldehyde or epoxy condensate resin.) }\end{array}$ \\
\hline
\end{tabular}

\begin{tabular}{||l|l|l|l|l|l|l||}
\hline \multicolumn{7}{|c|}{ Physical Examination Results } \\
\hline $\begin{array}{l}\text { IX } \\
\text { Column }\end{array}$ & $\begin{array}{l}\text { Drawing } \\
\text { Number }\end{array}$ & Column Type & $\begin{array}{l}\text { IX Wt.: } \\
\text { Dosign Emptyl } \\
\text { Actual (kg) }\end{array}$ & Resin? & Liquid? & Notes \\
\hline \hline R1 & H-3-14005 & RLIX-1 or RLIX-2 & - & YES & YES & 1 \\
\hline R2 & H-3-14005 & RLIX-1 or RLIX-2 & - & YES & YES & 1 \\
\hline R3 & H-3-14005 & RLIX-1 or RLIX-2 & - & YES & YES & 1 \\
\hline R4 & H-3-14005 & RLIX-1 or RLIX-2 & - & YES & NO & 1,4 \\
\hline R5/ \\
RLIX-1 & H-3-14005 & RLIX-1 & - & YES & YES & 1 \\
\hline L1 & H-3-14005 & RLIX-1 or RLIX-2 & - & YES & YES & 1 \\
\hline L2 & H-3-14005 & RLIX-1 or RLIX-2 & - & YES & YES & 1 \\
\hline L3 & H-3-14005 & RLIX-1 or RLIX-2 & - & YES & YES & 1 \\
\hline L4 & H-3-14005 & RLIX-1 or RLIX-2 & - & YES & NO & 1,4 \\
\hline C2 & H-3-14006 & RLIX-3 & - & YES & NO & 4 \\
\hline C3 & H-3-13990 & IX-1 or IX-4 & $230 / 240$ & NO & NO & $2,3,4$ \\
\hline C4 & H-3-13989 & IX-2 or IX-3 & $90 / 82$ & NO & NO & $2,3,4$ \\
\hline \hline
\end{tabular}

(1) Two designs for RLIX-1 and RLIX-2 ion exchangers are present in the RLAIX vault. Early column design (pre-1964) used upper and lower flow distribution grids. The last column design incorporated upper and lower spargers for flow distribution (see $\mathrm{H}-3-14005$, later revision).

(2) The estimated design weight of the IX without resin is based upon the $\mathrm{H}-3$ drawings.

(3) Based upon the process knowledge that the IX was not used, and fact that the estimated design weight of the IX and the actual weight of the IX are approximately the same, the IX is empty of resin and liquid.

(4) Based upon NDE, the IX is empty of liquid. 


\section{Filter Assembly}

The filter assembly was used during rupture loop decontamination conducted in 1966, (Ref H-3-15245 Shts 1\&2, "Rupture Loop Decontamination Details."

\section{References}

HW-63863, "Design Criteria for PRTR Fuel Element Rupture Test Facility".

HW-61236 Sup5, "PRTR Final Safeguards Analysis, Fuel Element Rupture Testing Analysis".

BNWL-40, "PRTR Fuel Element Rupture Test Facility Capabilities and Project History".

HWS-7928, "Proc. Spec. for Cleanup System Ion Exchangers, PRTR FERTF" 


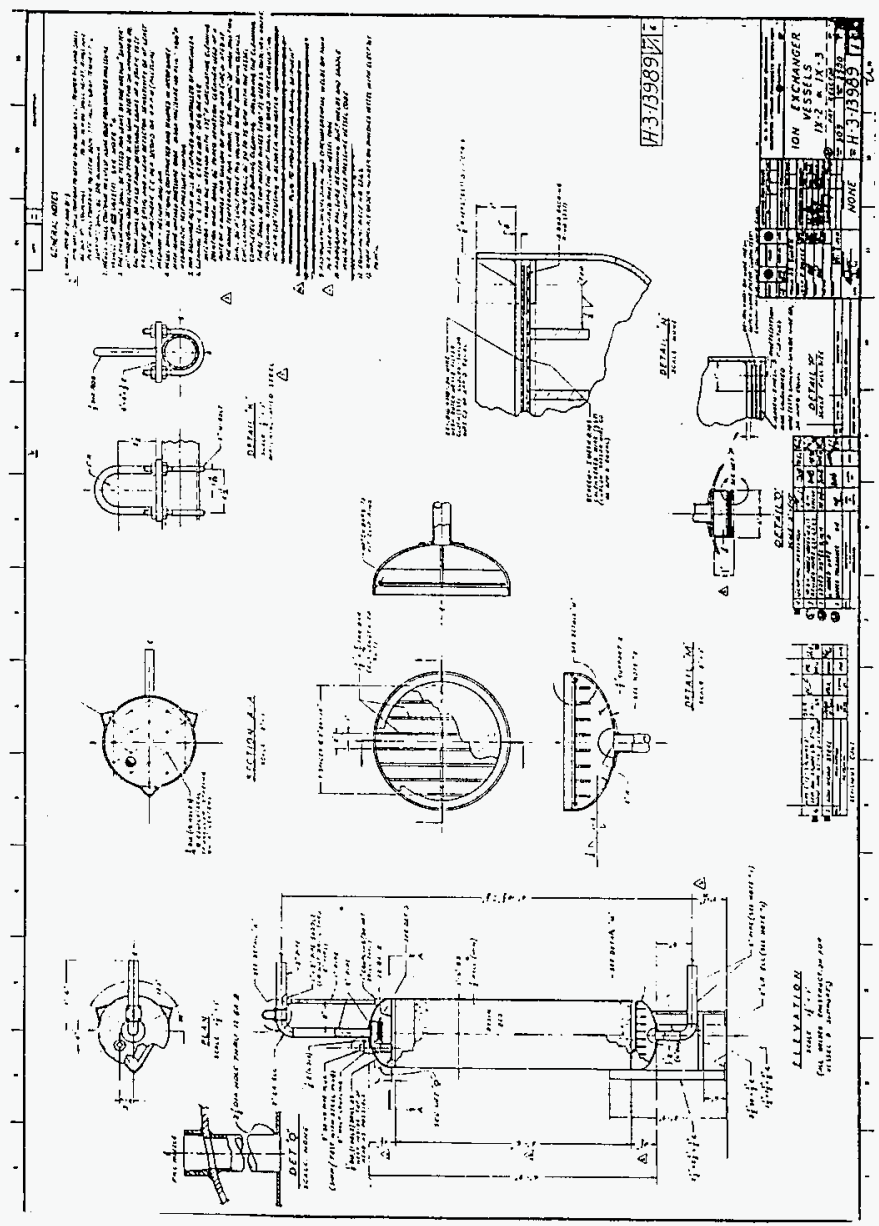

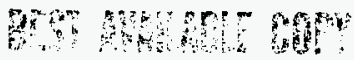




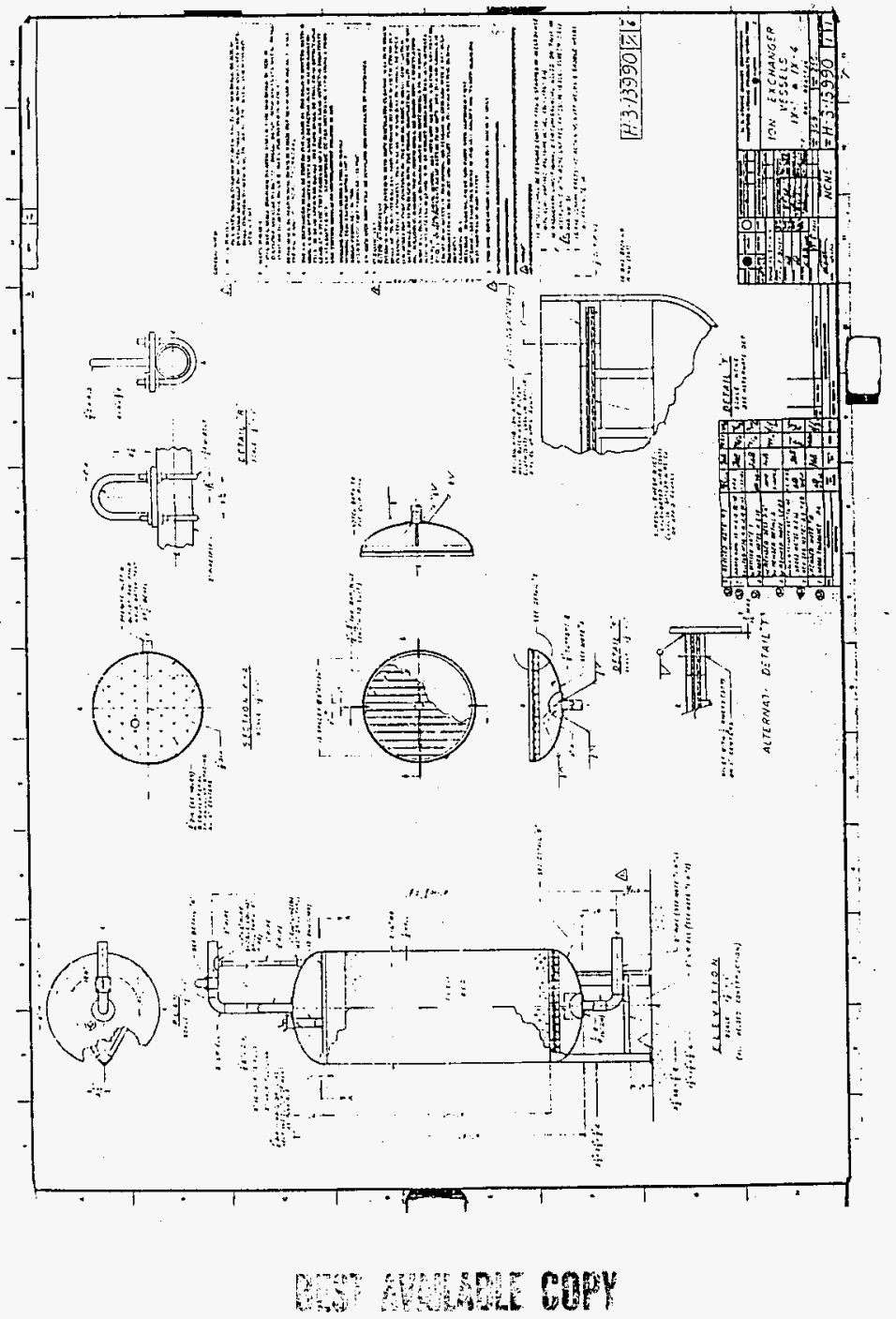




\section{ATTACHMENT II: Radiological Characterization}


February 20, 1996

\section{今. Battelle}

Puciric Northwest Labo: jooria;

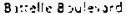

0.0 gis $5 \%$

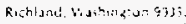

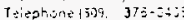

\section{J. E. Han}

Westinghouse Hanford Company

P. 0. Box 1970

Mail Stop L5-70

Richland, WA 99352

Dear Mr. Ham:

SUPPLENENTAL RESULTS OF FNML ASSAY OF 309 BUILOLNG RUPTURE. LOOP IX COLUMIS

Mr. Doug Duyon (HiHC) called recently asking me to elarify an activity level provided for ion exchange (IX) colurin C2 as contained on page 18 of my report to Mr. E. J. Bitten, dated November 10, 1995. The table provides the estinated $\alpha-$ particle activity concentration as measured using the PiNil lOA Passive Mioutron Counter. Mr. Duvon pointed ou: that the activity level exceeded the $100 \mathrm{nCi}-\alpha / \mathrm{g}$ level that defines TRL waste on the Hanford site".

I pointed out that the a-particle activity levels quoted are based on measured neutron emissions from the $I X$ column and represent conservative values since they are based on weapons-grade $\mathrm{PuO}_{2}$, which "yields the lowest neutron emission rate of any TRU material that can reasonably be expected in Hanford waste." Tha IX column in question was not identified in the summary report as exceeding the TRU limit because the PuO, in question was known to be fuels-grade $90 \mathrm{O}_{2}$ (11.65\% $2 \mathrm{2m} \mathrm{Pu}_{\mathrm{u}}$ ) fuelsgrade PuO, enits more neutrons per gram than weapons-grade and visuld be overestimated as a result. In addition, during the lest 29 yars. 75\% of the initial minor quantities of "Hi, a B-particle emitting isotope with a relatively short radioactive decay half life of 14.6 years, would haye decayed to ${ }^{21}$ An. an $a-$ particle emitting isotope with a moderate half ilfe of 434 years. The additional a-particle activity would also cause the apparent quantity of weapons-grade PuOa to be overestimated.

The purpose of this letter is to attach a revised table of results of the Pivil Passive Neutron Counter based on the actual isotopic ratios present in the failed PRTR fuel, corrected for the build-up of 21 Am in the intervening 29 years since fuel fabrication. The plutonium isotopic ratios were provided by Mr. Bruce Commell (biHC) as identified in a published Hanford report ${ }^{b}$.

The ${ }^{211}$ An accounts for roughly 38 \% of the $\alpha$-particle activity observed in the I $x$ colunns. This additional source of neutrons, together with the higher neutron

- Saction 5 of M. P. Willis, "Hanford site 5olid Wasta Acceptance Criterid," WHC-\{P-0053-4, October 1993 .

b D. E. Christensen, D. A. Kottwitz, D. R. Dden, and R. P. Matsen, July 1972. "Plutoniurth Recycle Burnup Data and Results from the Batch Core Experiment, BNWL-1674, Battelle, Pa:ific Northwest Laboratories, Richland. Washington. Refer to Table IV. page 21, for particulars. 
J. E. Ham

Page 2

February 20, 1996

emission rate from the spontaneous fission of the $11.65 \%{ }^{213} \mathrm{Pu}$, led to an estimate of plutonium weight $89 \%$ higher than the actual weight. The revised results are provided in Exhibit 1. Please note that the two columns previously identified as exceeding the TRU limit (C3 and CG), still exceed the TRU limit. However, column C2 is now correctly identified as being below the $100 \mathrm{nCi}-\alpha / \mathrm{g}$ limit.

Any further questions may be directed to me at Nail Stop P3-08, by cc:Hail, by FAX at 376-2329, or by phone at 376-0:05.

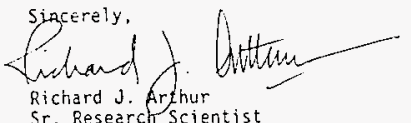

Sr. Research Scientist

Enclosures \& Attachments

cc w/attachments:

P.l Grifín, X5-53

DE Robertson, Pa-01

MD Winterrose, Po-0l

File / LB 


\section{Resuits of Passive Neutron Count: PNL Box Assayer Data}

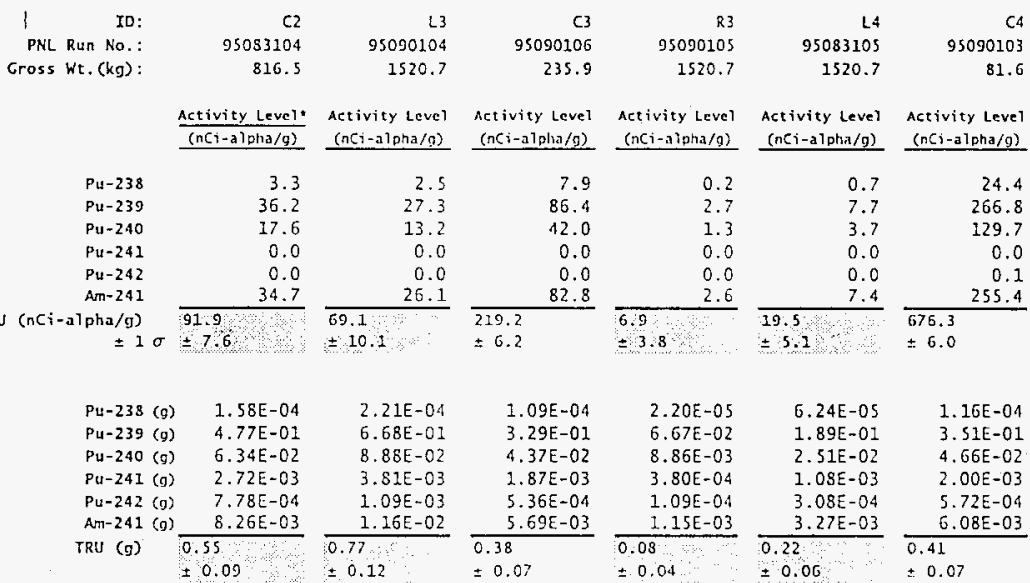

- Transuranic (TRU) "Activity Level" is hased mon the assumbtion of plutonum oxide elat is intimately in continct with ion excliange resin composed of $53 x$ oxyen. $22.5 x$ lichium of uncon, $20 \mathrm{k}$ sodiun, and fic silicon: weapons-grade Pu oxide is a conservative estimate since it yicids the lowest neutron enission rate of any tRU materia chat can reasonabiy be expected un lianford waste.

t The plutoniun oxide is based umon data found in Table IV of OE Christensen et al BNwL-2G7s (July after a 29 year decay, the resulting plutonium-isotopic fatio is Pu-238 $(0.03 \%)$. Pu-239 (87.68X). Pu-240 (11.65x). Pu-241 (0.05x), and Pu-242 $(0.14 x)$ and Ant-241 (1.S2X of Pu wh.) 


\section{RLAIX Fuel Isotope Content}

\begin{tabular}{|c|c|c|c|c|c|c|c|c|}
\hline Isotope & $\begin{array}{c}\text { Column } \\
\text { R3 } \\
\text { (grams) }\end{array}$ & $\begin{array}{c}\text { Column } \\
\text { R3 } \\
\text { (curies) }\end{array}$ & $\begin{array}{c}\text { Column } \\
\text { L3 } \\
\text { (grams) }\end{array}$ & $\begin{array}{c}\text { Column } \\
\text { L3 } \\
\text { (curies) }\end{array}$ & $\begin{array}{c}\text { Column } \\
\text { L4 } \\
\text { (grams) }\end{array}$ & $\begin{array}{c}\text { Column } \\
\text { L4 } \\
\text { (curies) }\end{array}$ & $\begin{array}{c}\text { Column } \\
\text { (grams) }\end{array}$ & $\begin{array}{c}\text { Column } \\
\text { C2 } \\
\text { (curies) }\end{array}$ \\
\hline $\begin{array}{l}\text { NDA } \\
\text { Results } \\
(1)\end{array}$ & 0.12 & - & 0.89 & - & 0.28 & - & 0.64 & - \\
\hline Am-241 & 0.01 & 3.23E-02 & 0.07 & 2.40E-01 & 0.02 & $7.54 \mathrm{E}-02$ & 0.05 & $1.72 E-01$ \\
\hline Np-237 & $<0.01$ & 3.13E-07 & $<0.01$ & 2.32E-06 & $<0.01$ & 7.31E-07 & $<0.01$ & 1.67E-06 \\
\hline $\mathrm{Pa}-233$ & $<0.01$ & 3.13E-07 & $<0.01$ & 2.32E-06 & $<0.01$ & 7.31E-07 & $<0.01$ & 1.67E-06 \\
\hline$U-234$ & $<0.01$ & 2.04E-06 & $<0.01$ & $1.51 \mathrm{E}-05$ & $<0.01$ & 4.76E-06 & $<0.01$ & $1.09 E-05$ \\
\hline U-235 & 0.04 & 9.01E-08 & 0.31 & $6.69 \mathrm{E}-07$ & 0.10 & $2.10 \mathrm{E}-07$ & 0.22 & 4.81E-07 \\
\hline U-236 & $<0.01$ & 4.65E-08 & 0.01 & $3.45 \mathrm{E}_{-07}$ & $<0.01$ & 1.09E-07 & $<0.01$ & $2.48 \mathrm{E}-07$ \\
\hline U-238 & 6.22 & 2.09E-06 & 46.12 & 1.55E-05 & 14.51 & 4.8BE-06 & 33.17 & 1.12E-05 \\
\hline Pu-238 & $<0.01$ & 5.73E-04 & $<0.01$ & $4.25 \mathrm{E}-03$ & $<0.01$ & 1.34E-03 & $<0.01$ & $3.06 \mathrm{E}-03$ \\
\hline Pu-239 & 0.11 & $6.62 E-03$ & 0.79 & $4.91 \mathrm{E}-02$ & 0.25 & $1.55 \mathrm{E}-02$ & 0.57 & $3.53 E-02$ \\
\hline$P_{u-240}$ & 0.01 & 2.99E-03 & 0.10 & $2.22 \mathrm{E}-02$ & 0.03 & $6.99 \mathrm{E}-03$ & 0.07 & 1.60E-02 \\
\hline $\mathrm{Pu}-241$ & $<0.01$ & 6.11E-02 & $<0.01$ & 4.53E-01 & $<0.01$ & 1.43E-01 & $<0.01$ & $3.26 \mathrm{E}-01$ \\
\hline $\mathrm{Pu}-242$ & $<0.01$ & 8.59E-07 & $<0.01$ & 6.37E-06 & $<0.01$ & 2.00E-06 & $<0.01$ & 4.58E-06 \\
\hline
\end{tabular}

(1) Conservative values calculated by using the nondestructive assay (NDA) value and adding the maximum error. 


\section{RLAIX Fission and Activation Product Isotope Content}

\begin{tabular}{|c|c|c|c|c|}
\hline IX Column & $\begin{array}{l}\mathrm{Cs}^{137} \\
\text { (Ci) }\end{array}$ & $\begin{array}{l}5 r^{90} \\
(\mathrm{Ci})\end{array}$ & $\begin{array}{l}\mathrm{Co}^{60} \\
\text { (Ci) }\end{array}$ & Notes \\
\hline $\mathrm{R} 1$ & $1.0094 E-02$ & $1.6 \mathrm{E}-03$ & $8.19 E-05$ & 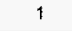 \\
\hline R2 & 4.66546E-01 & $7.5 E+02$ & $7.52 \mathrm{E}-04$ & 1 \\
\hline R3 & 1.1 & 1.8E-01 & $1.567 \mathrm{E}-03$ & 1 \\
\hline R4 & $3.7635 \mathrm{E}-02$ & $6.0 \mathrm{E}-03$ & 5.32E-04 & 1 \\
\hline R5/RLIX-1 & 0.0 & 0.0 & 7.7E-05 & 1 \\
\hline L1 & 4.302E-03 & $6.9 \mathrm{E}-04$ & 4.2E-05 & 1 \\
\hline L2 & 1.3613E-01 & 2.2E-02 & $1.73 E-04$ & 1 \\
\hline L3 & 2.1 & $3.4 \mathrm{E}-01$ & 1.33E-04 & 1 \\
\hline L4 & $1.0786 \mathrm{E}-02$ & $1.7 E-03$ & 1.24E-04 & 1 \\
\hline $\mathrm{C} 2$ & 0.003354 & $5.4 E-04$ & $8.94 \mathrm{E}-05$ & 1 \\
\hline C3 & 1.36E-09 & $2.2 \mathrm{E}-10$ & $1.55 \mathrm{E}-08$ & 1,2 \\
\hline $\mathrm{C} 4$ & $1,36 E-09$ & $2.2 \mathrm{E}-10$ & $1.55 \mathrm{E}-08$ & 1,2 \\
\hline $\begin{array}{l}\text { Filter Assembly } \\
\text { and Debris }\end{array}$ & bckgrnd & bckgrnd & bekgrnd & 3 \\
\hline
\end{tabular}

(1) ${ }^{90} \mathrm{Sr}$ to ${ }^{137} \mathrm{Cs}$ ratio is 0.16 . This ration is based on PRTR IX column laboratory analysis 222-S Lab RSA \#5804 (WHC-SD-NEL-ER-002).

(2) Columns $\mathrm{C} 3$ and $\mathrm{C} 4$ were moved to different positions in the RLAIX vault. Column $\mathrm{C} 4$ was recounted and shown to have lower ${ }^{137} \mathrm{Cs}$ and ${ }^{60} \mathrm{Co}$ levels than on the initial count done with the IXs in the positions near columns R3, L3, and R4. Dose rates of columns $\mathrm{C} 3$ and $\mathrm{C} 4$ dropped to background levels after moving them. Based upon this and the fact that both columns $\mathrm{C} 3$ and $\mathrm{C} 4$ were shown to be empty, column $\mathrm{C} 3$ is characterized as having the same radionuclide content as column $\mathrm{C} 4$.

(3) Readings were in the fractions of E-12 curies. 


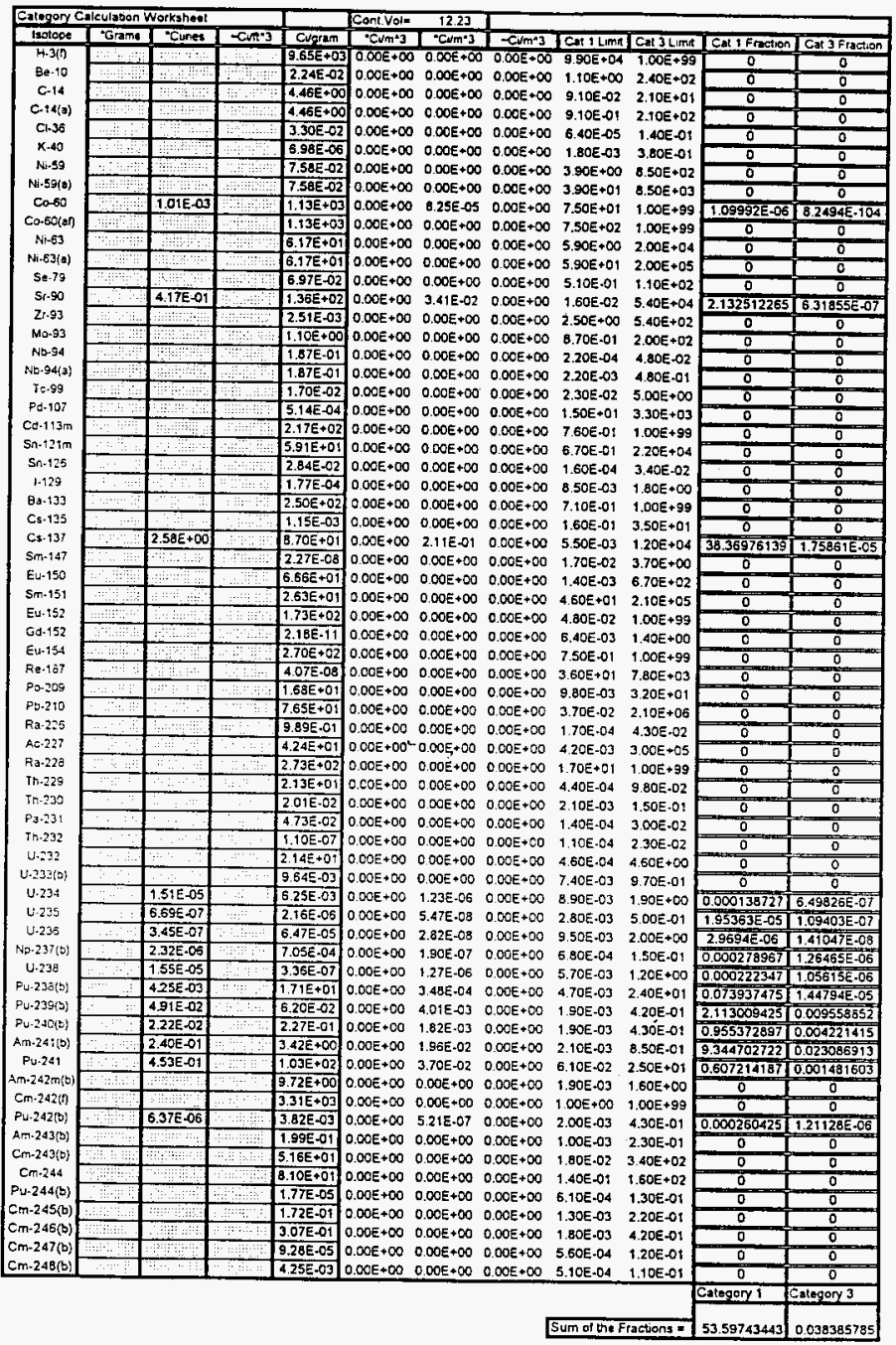

Eox 1:L3, L1, R1, R2

TRU< 100 nCig? 


\begin{tabular}{|c|c|c|c|c|c|c|c|c|c|c|c|}
\hline \multicolumn{4}{|c|}{ Categary Calculation Workshoet } & & \multicolumn{2}{|c|}{ Cont Val= $\quad 12.23$} & \multirow[b]{2}{*}{$-\left[u m^{*}+3\right.$} & \multirow[b]{2}{*}{ Col 1 Limnt } & \multirow[b]{2}{*}{ Cal 3 Lmt } & \multirow[b]{2}{*}{ Cat 1 Fraction } & \multirow[b]{2}{*}{ Cat joraction } \\
\hline Ixotope & "Grams & Cures & $-C_{n}:{ }^{\prime \prime}$ & CVoram & $=\mathrm{C} / \mathrm{m}+3$ & Cam?3 & & & & & \\
\hline $\mathrm{H}-3(\mathbf{n}$ & & & & $965 E+03$ & $0.00 E \cdot \infty 0$ & $0.00 E+\infty$ & $0.00 E+\infty$ & $9.00 E+04$ & $1.00 E+99$ & 0 & 0 \\
\hline $\mathrm{Be}-10$ & & $\because$ & $\ldots$ & $2.24 E-02$ & $0.00 E+00$ & $0.0 C E+\infty$ & $0.00 E+\infty$ & $1.10 E+\infty$ & $2.40 E+02$ & 0 & 0 \\
\hline C.14 & & n. & & $4.46 E+\infty$ & $0.00 E+00$ & $0.00 E+00$ & $0.00 E+00$ & $9.10 E-02$ & $2.10 E+0 t$ & 0 & 0 \\
\hline$c-14(a)$ & & $6 \ldots$ & $\therefore$ & $4.46 E+\infty$ & $0.00 E+\infty$ & $0.00 E+\infty 0$ & $0.00 E+\infty 0$ & $9.10 E-01$ & $2.10 E+02$ & 0 & 0 \\
\hline C1.35 & $\because$ & & & $3.30 \mathrm{E}-02$ & $0.00 E \cdot 00$ & $0.00 \Sigma=00$ & $0.00 E+\infty$ & 6. $40 E-05$ & $1.40 E-01$ & $\overline{0}$ & $\dot{0}$ \\
\hline$x-40$ & & & & $6.98 \mathrm{E}-06$ & $0.00 E+\infty$ & $0.00 E+00$ & $0.00 E+\infty 0$ & $1.80 E-03$ & 3.80E-01 & 0 & 0 \\
\hline N.59 & ii $\ldots \ldots$ & & & $7.58 \mathrm{E}-02$ & $0.00 E+00$ & $0.00 E+00$ & $0.00 E \cdot 00$ & $3.90 E+\infty$ & $8.50 E+02$ & 0 & 0 \\
\hline Ni-59(a) & $8: \div: 918$ & and & & $7.58 E .02$ & $0.005+\infty$ & $0.00 E+\infty 0$ & $0.00 E \cdot \infty$ & $3.90 E+01$ & $0.505+03$ & 0 & 0 \\
\hline Co- 60 & & ISSE.03 & & $1.13 \mathrm{E}+03$ & $0.00 E+\infty$ & $1,60 E-O A$ & $0.00 E+\infty$ & $7.50 E+01$ & $1.00 E+99$ & $2.12963 E 06$ & $1.5972 \mathrm{E}-103$ \\
\hline Ca-solaf & & Bin & & $t .13 E+03$ & $0.00 E+\infty$ & $0.00 E+00$ & $0.00 E+00$ & $7.50 E+02$ & $1.00 E+99$ & 0 & 0 \\
\hline $\mathrm{Ni}-63$ & 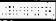 & 8 & 18 & 6.17E+01 & $0.00 E+\infty 0$ & $000 E+\infty 0$ & $0.00 E+00$ & $5.90 E+00$ & $2.00 E+Q 4$ & 0 & 0 \\
\hline$N_{1}-63(a)$ & 4 & & & $6.17 \mathrm{E}+01$ & $0.00 E+\infty$ & $0.00 E+00$ & $0.0 O E+\infty$ & $5.90 E * 01$ & $2.00 E+05$ & 0 & $\sigma$ \\
\hline Se-79 & & & & 6.97E-02 & $0.00 E+\infty$ & $0.00 E+\infty$ & $0.00 E+00$ & $5.10 E-01$ & $1.10 E+02$ & 0 & 0 \\
\hline $5 t+90$ & & $2.04 E-01$ & & $1,36 \mathrm{E}+02$ & $0.00 E+\infty 0$ & $1.67 \mathrm{E} .02$ & $0.00 E+\infty 0$ & 1.60E-02 & $5.40 E+04$ & 1.043744 & $3.09258 \mathrm{E} \cdot 07$ \\
\hline $2 t-59$ & & 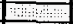 & & $2.51 E-03$ & $0.00 E+\infty$ & $0.00 E+\infty O$ & $0.00 E+\infty$ & $2.50 E+00$ & $5.40 E+02$ & 0 & 0 \\
\hline Mo-93 & & 4 & & $1.10 E+\infty$ & $0.00 E+00$ & $0.00 E+\infty$ & $0.00 E+00$ & $8.70 E-01$ & $2.00 E+02$ & 0 & 0 \\
\hline$N b-94$ & $\therefore$ & & & $1.87 E-01$ & $0.00 E+\infty$ & $0.00 E+00$ & $0.00 E+00$ & $2.20 E-04$ & 4. BOE-O2 & 0 & 0 \\
\hline No-94(a) & $\because \because \ldots$ & $\because:$ & & $1.87 \mathrm{E}-01$ & $0.00 E+\infty$ & $0.00 E+\infty$ & $0.00 E+\infty$ & $2,20 E-03$ & $4.80 E-01$ & 0 & 0 \\
\hline$T c .99$ & $+\infty$ & & $\therefore$ & $4.70 E-02$ & $0.00 E+\infty$ & $0.00 E+\infty$ & $0.00 E+\infty 0$ & $2.30 E-02$ & $5.00 E+\infty$ & 0 & 0 \\
\hline PQ-107 & $\therefore \%$ & $\because 4$ & & $5.14 E-04$ & $0.00 E+00$ & $0.00 E+00$ & $0.00 E+00$ & $1.50 E \div 01$ & $3.30 E+03$ & 0 & 0 \\
\hline co. $113 \mathrm{~m}$ & & & & $2.17 \mathrm{E}+02$ & $0.00 E+00$ & $0.00 E+\infty 0$ & $0.00 E+\infty 0$ & 7.60E-01 & $1.00 E+99$ & 0 & 0 \\
\hline$S_{n+12} t m$ & & & & $5.91 E+01$ & $0.00 E+\infty$ & $0.00 E+\infty$ & $0.00 E+00$ & $6.705-01$ & $2.20 E+04$ & 0 & 0 \\
\hline Sn-125 & ; & & $\ldots$ & 2.B4E-02 & $0.00 E+\infty$ & $0.00 E+\infty 0$ & $0.00 E+00$ & $1.50 E-04$ & $3.40 E .02$ & 0 & 0 \\
\hline $1-129$ & & $\ldots$ & & 1.77E-04 & $0.00 E+00$ & $0.00 E+00$ & $0.00 E+00$ & 8.50E-03 & $1.80 E \cdot \infty 0$ & 0 & 0 \\
\hline 8.-133 & $\because: \cdot$ & & & $2.50 E+02$ & $0.00 E+\infty$ & $0.00 E+\infty 0$ & $0.00 E+00$ & 7.10E-01 & $1.00 E+99$ & 0 & 0 \\
\hline Cs.13s & & & & $1.15 E .03$ & $0.00 E+00$ & $0.00 E+\infty$ & $0.00 E+00$ & $1.60 E-01$ & $3.50 E+01$ & 0 & 0 \\
\hline Cs.13T & & $1.255+00$ & & $3.70 E+01$ & $0.00 E+\infty$ & $1.02 \equiv-01$ & $0.00 E+\infty$ & $5.50 E-03$ & $1.20 E+04$ & 18.58722 & 8.51915E-06 \\
\hline $5 m-147$ & 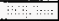 & $7:=$ & & $2.27 \mathrm{E} \cdot 08$ & $0.00 E+\infty$ & $0.00 E+\infty$ & $0.00 E+\infty$ & $1.70 E=02$ & $3.70 E \cdot \infty$ & 0 & $\overline{0}$ \\
\hline Eu. 150 & 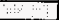 & $\ldots$ & & $566 E+01$ & $0.00 E+00$ & $0.00 E+\infty 0$ & $0.00 E+00$ & $1.40 E-03$ & $6.70 E+02$ & 0 & 0 \\
\hline Sm- 151 & $\therefore \because:$ & $\therefore$ & i: & $2.63 E+0:$ & $0.00 E+\infty$ & $0.00 E+\infty 0$ & $0.00 E+00$ & $460 E+01$ & $2.10 E+05$ & 0 & 0 \\
\hline Eu-152 & $\therefore$ & 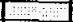 & & $1.73 \mathrm{E}+02$ & $0.00 \varepsilon+\infty$ & $0.00 E+\infty$ & $0.00 E+\infty 0$ & 4.80E .02 & $1.00 E+99$ & 0 & 0 \\
\hline Ga-152 & $x n$ & $\therefore$ & $\therefore$ & $2.18 E-11$ & $0.00 E+\infty$ & $0.00 E+00$ & $0.00 E+\infty$ & 6.40E-03 & $1.40 E+\infty$ & 0 & 0 \\
\hline Eu-154 & 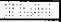 & $\cdots$ & & $2.70 \mathrm{E}+\mathrm{CZ}$ & $0.00 E+00$ & $0.00 E+00$ & $0.00 E+00$ & 7.\$OE-01 & $1.00 E+99$ & 0 & 0 \\
\hline Re-187 & 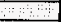 & $\cdots$ & & 407E-0B & $0.00 E+\infty 0$ & $0.00 E+00$ & $0.00 E+\infty$ & $3.60 \varepsilon+01$ & $7.80 \mathrm{E}+03$ & 0 & c \\
\hline $\mathrm{Pa-209}$ & 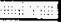 & & 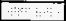 & $t .68 E+01$ & $0.00 \leqslant+\infty$ & $0.00 E+00$ & $0.00 E+\infty$ & $9.80 \varepsilon .03$ & $3.20 t+01$ & 0 & 0 \\
\hline PE-210 & 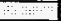 & & $\therefore$ & $7.65 E+01$ & $0.00 \varepsilon+00$ & $0.00 E+00$ & $0.005+00$ & $3.70 E-02$ & $2.10 E+06$ & 0 & 0 \\
\hline Ra-225 & 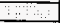 & & & $989 \mathrm{E}-01$ & $0.00 E+00$ & $0.00 E+\infty$ & $0.00 E+00$ & 1. rOE-04 & $4.30 \mathrm{E}-02$ & $\overline{0}$ & 0 \\
\hline Ac- 237 & $\ldots$ & & & $4.24 \mathrm{E}+01$ & $0.00 E+00^{\circ}$ & $0.00 E+\infty$ & $0.00 E+00$ & $4.20 E .03$ & $3.00 E+05$ & 0 & 0 \\
\hline Ra. 228 & & $\because$ & & $2.73 \mathrm{E}+02$ & $0.00 E+\infty 0$ & $0.00 E+\infty$ & $0.00 E+00$ & $1.70 E+01$ & $1.00 E+99$ & 0 & $\overline{0}$ \\
\hline Th. 229 & & & & $2.13 E+01$ & $0.002+\infty$ & $O O O E+0 O$ & $0.00 E+00$ & $4.40 E-04$ & $9.80 E+02$ & 0 & 0 \\
\hline $7 \mathrm{~s} \cdot 230$ & & & & $2.01 E-02$ & $0.00 E+00$ & $0.00 E+00$ & $0.00 \varepsilon+00$ & 2.10E-03 & 1.50E-01 & 0 & 웅 \\
\hline Pa.231 & & & & $4.73 E .02$ & $0.00 E+\infty 0$ & $0.00 E+00$ & $0.00 E+\infty 0$ & 1.40E-04 & 3.00E-02 & 逢 & 0 \\
\hline Th. 232 & & & & $1.10 E-07$ & $0.00 E+\infty 0$ & $0.00 \varepsilon+\infty$ & $0.00 E+\infty 0$ & 4. $10 E-04$ & $2.30 E-02$ & 0 & 0 \\
\hline U.232 & & & & $2.14 E+01$ & $0.00 E+00$ & $0.00 E+00$ & $0.00 E+00$ & 4.60E-O4 & $460 E+\infty$ & $\overline{0}$ & 0 \\
\hline$U .233(\theta)$ & & & & 5.64E.03 & $0.00 E+00$ & $0.00 E+00$ & $0.00 E+C 0$ & $7.40 \mathrm{E}-03$ & $9.70 E-01$ & 0 & 0 \\
\hline U.234 & & $1.77 \mathrm{E}-0.5$ & & 6.25E-03 & $0.00 \equiv+00$ & 1.45E-06 & $0.00 E+\infty 0$ & 8.90E-03 & $1,90 E+\infty 0$ & 0.000162614 & $7.61716 \mathrm{E} .07$ \\
\hline U.235 & & $7.81 E-07$ & & $2.16 E .05$ & $0.00 E+\infty$ & $6.39 E-08$ & $0.00 E+\infty$ & $2.80 E-03$ & $5.00 E-01$ & $2.28098 \mathrm{E}-05$ & $1.27735 E-07$ \\
\hline $4 \cdot 236$ & & 4.04E-07 & & $6.47 E-0 S$ & $0.00 E+00$ & $3.30 E-08$ & $0.00 E+00$ & $9.50 E-03$ & $2.00 \varepsilon+\infty$ & $3.47291 \mathrm{E}-06$ & $1.64953 \mathrm{E}-08$ \\
\hline Aม-297(b) & & $2.71 E-05$ & $\therefore$ & $7.05 E .04$ & $0.00 E+00$ & $2.22 E-07$ & $0.00 E+00$ & $6.80 \mathrm{E}-04$ & $1.50 E-01$ & 0.000325862 & $1.47724=06$ \\
\hline U.236 & & $1.82 E .05$ & & $3.36 \mathrm{E} .07$ & $0.00 E+00$ & $1.49 E-06$ & $0.00 E+\infty 0$ & $5.705-03$ & $1.20 E+\infty O$ & 0.000260648 & $1.23606 \mathrm{E} .06$ \\
\hline Pu-23e(b) & & 4.97E-03 & & $1.71 E * 07$ & $0.00 E+\infty 0$ & 4.07E.04 & $0.00 E+\infty$ & $4.70 E-03$ & $2.40 E+01$ & 0.086515544 & 7.69425E-05 \\
\hline Pu-239(0) & 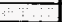 & $5.74 E-02$ & & $6.20 \mathrm{E}-02$ & $0.00 E+\infty 0$ & $4.70 E-03$ & $0.00 E+00$ & $1.90 E-03$ & 4.20E.01 & 2.471059087 & 0.011178601 \\
\hline$P u-240(b)$ & $\therefore$ & $2.605-02$ & 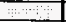 & $2.27 \mathrm{E}-01$ & $0.00 E+00$ & $2.12 E-03$ & $0.00 E+\infty 0$ & $1.90 \mathrm{E}-03$ & 4.30E-01 & 1.118044498 & 0.004940197 \\
\hline$A m-241(3)$ & & $2.80 E-01$ & $\therefore \quad: \because::$ & $3.42 E+00$ & $0.00 E+00$ & $2.29 \mathrm{E}-02$ & $0.00 \varepsilon+00$ & $2.10 E-03$ & $8.50 E-01$ & 10.6904723 & 0.026905873 \\
\hline$P 4.241$ & & 5.30E-01 & & $1.03 E+02$ & $0.00 E+00$ & 4.335 .02 & $0.00 E+00$ & $6.10 E-02$ & $2.50 E+01$ & 0.710551237 & 0.001733759 \\
\hline $2 m-242 m(b)$ & $5 \ldots$ & $\ldots$ & & $9.72 \varepsilon+00$ & $0.00 E+\infty$ & $0.00 E+\infty$ & $0.00 E+00$ & $1.90 \mathrm{E}-03$ & $1.60 E+\infty$ & 0 & 0 \\
\hline$C_{m-242(1)}$ & & +4 & 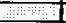 & $3.31 E+03$ & $0.00 E+\infty$ & $0.00 E+\infty O$ & $0.00 E+\infty$ & $1 . \operatorname{CoE}+\infty$ & $1.00 E+99$ & 0 & 0 \\
\hline$P u-242(b)$ & 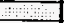 & $7.44 E-06$ & 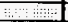 & $3.82 E+03$ & $0.00 E+\infty$ & $6.08 E-07$ & $0.00 E+00$ & $2.00 E-03$ & $4.30 E-01$ & 0.000304129 & $.41455 E-05$ \\
\hline$A m-243(b)$ & 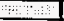 & (1): & 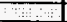 & 1.99E-01 & $0.00 E+00$ & $0.00 E+00$ & $0.00 E+\infty 0$ & $1.00 \mathrm{E}-03$ & $2.30 E-01$ & 0 & o \\
\hline $\mathrm{Cm}-2 \mathrm{al}(\mathrm{b})$ & 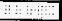 & 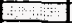 & $: \because$ & $5.16 \mathrm{E}+01$ & $0.00 E+00$ & $0.00 E+00$ & $0.00 E+\infty$ & $1.80 E-02$ & $3.40 E+02$ & 0 & 0 \\
\hline $\mathrm{Cm}-244$ & nem & 5 & 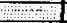 & $8105+01$ & $0.00 E+\infty$ & $0.00 E+\infty$ & $0.00 E+\infty 0$ & 1. $\triangle 0 E-01$ & $1.60 E+\sigma 2$ & 0 & 0 \\
\hline Pu-244(b) & : : & in. & 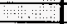 & 1.77E-05 & $0.00 E+\infty$ & $0.00 E * 00$ & $0.00 E+00$ & 6.10E-04 & $1.30 E-01$ & 0 & 0 \\
\hline $\mathrm{Cm}-245(\mathrm{~b})$ & 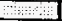 & : & An: & $1.72 E-01$ & $0.00 E+\infty 0$ & $0.00 E+00$ & $0.00 E+\infty 0$ & $1.30 E-03$ & $2.20 E-01$ & 0 & 0 \\
\hline$C_{m-245(b)}$ & : & 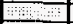 & : & $3.07 E-01$ & $0.00 E+\infty$ & $0.00 E+00$ & $0.00 E+\infty$ & $1.805-03$ & $4.20 E-01$ & 0 & 0 \\
\hline $\mathrm{Cm}-247(\mathrm{~b})$ & $\ldots$ & 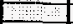 & & $9.28 E-05$ & $0.00 E+\infty$ & $0.00 E+00$ & $0.00 E+\infty O$ & $\$ .50 E-04$ & $1.20 E-01$ & 0 & 0 \\
\hline $\mathrm{Cm}-248$ (b) & $\therefore$ & $\therefore$ & & $4.25 E .03$ & $0.00 E+00$ & $0.00 E+\infty$ & $0.00 E+00$ & $5.10 \mathrm{E} \cdot 04$ & $1.10 E-01$ & 0 & 0 \\
\hline & & & & & & & & & & Categor 1 & egory 3 \\
\hline & & & & & & & & m & & 34.80870893 & 0.04478924 \\
\hline
\end{tabular}

BOX 2: R3, $\mathrm{C2}^{2,12,14}$

TRU $<100 \mathrm{nCV} / \mathrm{g}$ 
Page D - 23

WHC-SD-NEL-ER-004 Rev. 0

\begin{tabular}{|c|c|c|c|c|c|c|c|c|c|c|c|}
\hline \multicolumn{4}{|c|}{ Calegory Calculation Worxsheol } & \multicolumn{3}{|c|}{ Cont.Vol $=12.23$} & \multirow[b]{2}{*}{$-\mathrm{Cum}^{\prime} 3$} & \multirow[b]{2}{*}{ Ca! 1 Limn } & \multirow[b]{2}{*}{ Cat J LimA } & \multirow[b]{2}{*}{ Cat I Fraction } & \multirow[b]{2}{*}{ Cat 3Frostion } \\
\hline Isctope & Trams & Curnes & $-\operatorname{con} \div 3$ & Cugtam & $\mathrm{Cum}^{n} 3$ & $\mathrm{Cum}^{4} 3$ & & & & & \\
\hline $\mathrm{H}-3 \mathrm{H}$ & & & & $9.65 E+03$ & $000 E+\infty$ & $0.00 E+\infty 0$ & $0.00 E+\infty$ & $9.90 E \cdot 04$ & $100 E \div 99$ & 0 & 0 \\
\hline Be-10 & $\because$ & $\therefore$ & $\cdots: \therefore \quad \therefore \quad$ & $2.24 \mathrm{E}-02$ & $0.00 E+\infty$ & $D .00 E+\infty 0$ & $0.00 E+\infty$ & $1.10 E+\infty 0$ & $240 E+02$ & 0 & 0 \\
\hline C-14 & & & & $4.46 \mathrm{E} \cdot 00$ & $0.00 E+\infty$ & $0.00 \varepsilon \rightarrow \infty$ & $0.00 E+00$ & $9.10 \mathrm{E}-02$ & $2.10 \mathrm{E}+0 \mathrm{t}$ & 0 & 0 \\
\hline$C \cdot t 4(3)$ & & $\therefore: \div$ & & $4,46 E+00$ & $0.00 E+\infty$ & $0,00 E+\infty$ & $0.00 E+00$ & $9.10 \mathrm{E}-01$ & $2.10 E+02$ & 0 & 0 \\
\hline $0:-36$ & & ii: & & $3.30 E-02$ & $0.00 E+\infty$ & $0.00 E+\infty$ & $0.00 E+00$ & 6.40E -05 & $1,40 E-01$ & 0 & 0 \\
\hline$K-40$ & 1 & $+\cdots$ & $\because$ & $6.99 \mathrm{E}-06$ & $0.00 E+\infty 0$ & $0,00 E+\infty$ & $0.00 E+00$ & $1.80 E-03$ & $3.80 E-01$ & 0 & $\frac{1}{0}$ \\
\hline $\mathrm{Ni}+59$ & 6:at: & Fin & $\ldots$ & $7.58 \mathrm{E}-02$ & $0.00 E+\infty$ & $0.00 E+\infty$ & $0.00 E+00$ & $3.90 E \div 00$ & $8.50 E+02$ & 0 & 0 \\
\hline Ni.59(a) & $\because+18$ & 6i:日: & & $7,58 \mathrm{~B}-02$ & $0.00 E+\infty$ & $0.00 E+\infty$ & $0.00 E+00$ & $3,90 E+01$ & $8.50 \mathrm{E}+03$ & 0 & 0 \\
\hline $\mathrm{C}_{0}-60$ & 90 & $6.09 \mathrm{E}-04$ & 6 & $1.135+03$ & $0.00 E+\infty 0$ & 4.98E-OS & $0.00 E+00$ & $7.50 E+01$ & $1.00 E+99$ & $6.63975 E-07$ & $4.9798 \mathrm{E} \cdot 104$ \\
\hline Co- $\$ 0(a n)$ & + & \%1 & 8 in & $1.13 E+03$ & $0.00 E+00$ & $0.00 E+\infty$ & $0.00 E+\infty 0$ & $7.50 E+02$ & $1.00 E+99$ & 0 & 0 \\
\hline $\mathrm{Ni}-63$ & $\therefore$ & 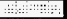 & H: & $6.17 E+01$ & $0.00 E+00$ & $0.00 E+\infty$ & $0.00 E+\infty 0$ & $5.906+00$ & $2.00 E+04$ & 0 & 0 \\
\hline$N i-63(a)$ & $+\cdots$ & +min & & $6.17 \varepsilon+01$ & $0,00 E+00$ & $0.00 E+\infty$ & $0.00 E+00$ & $5.90 E+01$ & $2.00 E * 05$ & 0 & 0 \\
\hline Se-79 & :!:!: & 69 & 7 & $6.97 \mathrm{E}-02$ & $0.00 E+\infty$ & $0.00 E+\infty$ & $0.00 E+\infty$ & 5.10E-01 & $1.10 E+02$ & 0 & 0 \\
\hline $5 t-90$ & E & $6,005-03$ & & $1.36 \mathrm{E}+02$ & $0.00 E+00$ & $4.91 \varepsilon-04$ & $0.00 E+\infty$ & $1.60 E-02$ & $5.40 E+04$ & 0.030682 & .08513E-09 \\
\hline $2 r+90$ & H. & 4 & +6 & $2.51 E-03$ & $0.00 E+\infty$ & $0.00 E+\infty$ & $0.00 E+\infty$ & $2.50 E+\infty 0$ & $5.40 E+02$ & 0 & 0 \\
\hline Mo-93 & 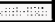 & & :: & $1.10 E+00$ & $0.00 E+\infty$ & $0.00 E+\infty$ & $0.00 E+00$ & $6.70 E-01$ & $2.00 E+02$ & 0 & 0 \\
\hline $\mathrm{Nb}-94$ & : & & & 1.87E-01 & $0.00 E+00$ & $0.00 E+\infty$ & $0.00 E+00$ & $220 E-04$ & $4.00 \varepsilon-02$ & 0 & 0 \\
\hline$N b-94(a)$ & & & & 1.8TE-01 & $0.00 E+\infty$ & $0.00 E+\infty$ & $0.00 E+\infty 0$ & $2.20 E-03$ & $4.80 E-01$ & D & 0 \\
\hline$T_{5} .99$ & & $\because$ & & $1.70 E-02$ & $10.00 E+00$ & $0.00 E+\infty$ & $0.00 E+00$ & $2.305-02$ & $5.00 E+\infty 0$ & $\overline{0}$ & 0 \\
\hline Fd.107 & & $\therefore . .8$ & & $5.14 E-04$ & $0.00 E+\infty$ & $0.00 E+\infty 0$ & $0.00 E+\infty$ & $1.50 E+01$ & $3.30 E+03$ & 0 & 0 \\
\hline $\mathrm{C} d .113 \mathrm{~m}$ & $\because \because$ & 4 & & $2.17 E+02$ & $0.00 E+\infty 0$ & $0.00 E+\infty$ & $0.00 E+00$ & 7.60E-01 & $1.00 E+99$ & $\overline{0}$ & 0 \\
\hline $\mathrm{sn} \cdot 121 \mathrm{~m}$ & ii: & . . . & 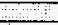 & $5.91 E+01$ & $0.00 E+\infty$ & $0.00 E+00$ & $0.005+\infty$ & 6.70E-01 & $2.20 E+04$ & 0 & 0 \\
\hline $5 n .126$ & $\therefore: \div$ & $\because \ldots \ldots$ & $\because \cdots$ & $2.84 E-02$ & $0.00 E+00$ & $0.00 E+\infty$ & $0.00 E+00$ & $1.60 E-04$ & $3.40 \pm .02$ & D & 0 \\
\hline 1.129 & $\therefore$ & & $\pi$ & $1.77 E-04$ & $0.00 E+\infty$ & $0.00 E+\infty$ & $0.00 E+\infty$ & $8.50 \varepsilon-03$ & $1.60 E+00$ & 0 & 0 \\
\hline Ea-133 & $+\ldots$ & 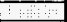 & $\because$ & $2.50 E+02$ & $0.00 E+\infty$ & $0.00 E+\infty$ & $0.00 E+00$ & 7.10E-01 & $1.00 E+99$ & 0 & 0 \\
\hline Cs- 175 & & & & $1.15 \mathrm{E}-03$ & $0.00 E+\infty$ & $0.00 E+\infty 0$ & $0.00 E+00$ & $1.60 E-01$ & $3.50 \mathrm{E}+01$ & 0 & 0 \\
\hline Cs.137 & $\therefore$ & $3.76 E-02$ & $\therefore$ & $8.70 \mathrm{E}-01$ & $0.00 E+\infty$ & 3.085 .03 & $0.00 E+00$ & $5.50 E-03$ & $1.20 E+04$ & 0.559503497 & $2.56439 \mathrm{E}-07$ \\
\hline $5 m-147$ & : & $\ldots \ldots$ & 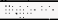 & 2.27E-08 & $0.00 E+00$ & $0.00 E+00$ & $0.00 E+00$ & $1.70 E-02$ & $3.70 E+00$ & 0 & 0 \\
\hline Ev-150 & 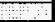 & $\cdots$ & 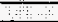 & $6.66 \mathrm{E}+01$ & $0.00 E+00$ & $0.00 E+\infty$ & $0.005+00$ & $1,40 E-03$ & $6.70 E+02$ & 0 & 0 \\
\hline$s m-151$ & $\therefore$ & $\because \ldots$ & 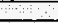 & $2.63 \mathrm{E}+01$ & $0,00 E+\infty$ & $0.00 E+00$ & $0.00 \mathrm{E}+00$ & $4.60 E+01$ & $2.10 E+05$ & 0 & 0 \\
\hline Eu.152 & 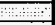 & : :": & $\therefore \quad \therefore$ & $1,7 \mathrm{JE}+02$ & $0.00 E * \infty$ & $0.00 E+00$ & $0.00 E+00$ & 4.808 .02 & $1.00 E+99$ & 0 & 0 \\
\hline Gd-152 & $\therefore i$ & 6 & 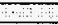 & $2.18 \mathrm{E}-11$ & $0.00 E+00$ & $0.00 E+\infty$ & $0.00 E+00$ & $6.40 E-03$ & $1.40 E+O 0$ & 0 & 0 \\
\hline$E u+154$ & 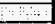 & : & $\therefore$ & $2.70 \mathrm{E}+02$ & $0,00 E+00$ & $0.00 E+00$ & $0.00 E+00$ & $750 E-01$ & $1.00 E+99$ & 0 & 0 \\
\hline Re- 197 & 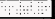 & $\therefore$ & $\ldots$ & 4.07E-0a & $0.00 E+\infty$ & $0.00 E+00$ & $0.00 E+00$ & $3.60 E+01$ & $7.805+03$ & d & 0 \\
\hline$p 0.209$ & $\ldots$ & $=$ & $\therefore \therefore$ & $1.68 \mathrm{E}+01$ & $0.00 E+00$ & $0.00 E+\infty$ & $0.00 E+\infty 0$ & $9.80 E-03$ & $3.20 E+01$ & 0 & 0 \\
\hline PD.210 & $\because \%$ & $\because \cdots$ & & $7.65 \mathrm{E}+01$ & $0.00 E+\infty$ & $0.00 E+\infty$ & $0.00 E+00$ & $3.70 E+02$ & $2.10 \mathrm{E}+06$ & $\pi$ & 0 \\
\hline $\mathrm{Ra} \cdot 22 \mathrm{~S}$ & $\therefore$ & 6 & & $5.89 E-01$ & $0.00 E+00$ & $0.00 E+00$ & $0.00 E+00$ & $1.70 E-04$ & 4.30E-02 & 0 & 0 \\
\hline Ac 227 & $\because \quad 4$ & $\cdots$ & & $4.24 E+01$ & $0.00 E+00^{\circ}$ & $0.00 E+00$ & $0.00 E+00$ & $420 E-03$ & $3.00 E+05$ & 0 & 0 \\
\hline $\operatorname{Ra}-228$ & $\ldots$ & $\therefore$ & $\therefore$ & $2.73 \mathrm{E}+02$ & $0.00 E+00$ & $0.00 E+00$ & $0.00 E+00$ & $1.70 E+01$ & $1.00 E+99$ & 0 & 0 \\
\hline$T n .229$ & & & & $2.73 \mathrm{E}+01$ & $0.00 E+00$ & $0.00 E+00$ & $0.00 E+00$ & $4.40 E-04$ & $9.80 E-02$ & 0 & 0 \\
\hline$T r_{-}-230$ & & $\cdots$ & & $2.01 E .02$ & $0.00 E+\infty 0$ & $0.00 E+00$ & $0.00 E+00$ & 2 t0E.03 & $1.50 E-01$ & 0 & 0 \\
\hline Pa.231 & & & & $4.73 \mathrm{E}-02$ & $0.00 E+\infty 0$ & $0.00 E+\infty 0$ & $0.00 E+00$ & $1.40 \mathrm{E}-04$ & $3.00 \mathrm{E} \cdot 02$ & 0 & 0 \\
\hline In.232 & $\cdots$ & & & $1.10 \mathrm{E} .07$ & $0.00 E+\infty$ & $0.00 E+00$ & $0.00 E+\infty 0$ & $1.10 \mathrm{E}-04$ & 2.30E-02 & 0 & 0 \\
\hline U. 232 & & & & $2.34 E+01$ & $0.00 E+00$ & $000 E+\infty$ & $0.00 E+00$ & $460 E-04$ & $4.60 E+00$ & 0 & 0 \\
\hline U. $233(\mathrm{~s})$ & & $\therefore$ & : & 9.64E.03 & $0.00 E+\infty$ & $0.00 E+00$ & $0.00 E+00$ & $7.40 E .03$ & $9.70 E \cdot 01$ & 0 & 0 \\
\hline U. 234 & ; & $\cdots$ & & $6.25 \mathrm{E}-03$ & $0.00 E+00$ & $0.00 E+00$ & $0.00 E+00$ & $8.90 E-03$ & $1.90 \mathrm{E}+00$ & 0 & 0 \\
\hline U. 235 & $\therefore \ldots$ & $\therefore \ldots$ & $\therefore \quad \ldots$ & $2.16 E-06$ & $0.00 E+00$ & $0.00 E+00$ & $0.00 E * 00$ & $2.90 E-03$ & $5.00 E-01$ & 0 & 0 \\
\hline U.236 & $\because$ & 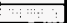 & $\cdots$ & $6.47 \mathrm{E} .05$ & $0.00 E+00$ & $0.00 E+\infty$ & $0.00 \mathrm{E} \cdot 00$ & $9.50 E-03$ & $2.00 \mathrm{E}+00$ & 0 & 0 \\
\hline$N_{p}-937(b)$ & $\ldots$ & 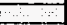 & & $7.05 E \cdot 0.4$ & $0.00 E+\infty$ & $0.00 E+00$ & $0.00 E+00$ & $680 E-04$ & $1.50 E-01$ & 0 & 0 \\
\hline$U-238$ & $\therefore \quad \because \quad$ & 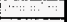 & $\because: \quad:$ & $3.36 \mathrm{E}-07$ & $0.00 E+\infty 0$ & $0.00 E+00$ & $0.00 E+00$ & 5.7OE-C3 & 1.20E+DO & 0 & 0 \\
\hline$P \cup-238(b)$ & $\because \therefore \therefore$ & $\therefore \therefore$ & & $1.71 E+01$ & $0.00 E+\infty$ & $0.00 E+00$ & $0.00 E+00$ & 4.70E-03 & $2.40 E+01$ & 0 & 0 \\
\hline Pu-239(b) & 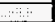 & 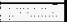 & & $6.20 \mathrm{E}-02$ & $0.00 E+00$ & $0.00 E+00$ & $0.00 E+00$ & $1.90 E-03$ & 4.20E-01 & C & $\overline{0}$ \\
\hline$P \cup-240(b)$ & & $\square$ & $\cdots$ & 2.27E-01 & $0.00 E+00$ & $0.00 E+\infty$ & $0.00 E+\infty 0$ & $190 \mathrm{E}-03$ & $4.30 E-01$ & 0 & 0 \\
\hline Am-241(D) & 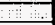 & $\therefore$ & $\therefore: \cdots$ & $3,42 \mathrm{E}+00$ & $0.00 E+00$ & $0.00 E+00$ & $0.00 E+00$ & $2.10 \mathrm{E}-03$ & 8.50E-01 & 0 & 0 \\
\hline Pu-24, & $\cdots$ & $\therefore$ & $\because$ & $1.03 E+02$ & $0.00 E+\infty$ & $0.00 E+\infty$ & $0.00 E+\infty$ & $6.10 \mathrm{E}-02$ & $2.50 E+0 t$ & 0 & 0 \\
\hline $2 \mathrm{~m} \cdot 242 \mathrm{~m}(\mathrm{D})$ & & & & $9.72 E+00$ & $0.00 E+00$ & $0.00 E+00$ & $0.00 E+\infty$ & $1.90 E-03$ & $1.60 E+\infty 0$ & 0 & 0 \\
\hline $\mathrm{Cm}-242(0)$ & 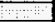 & $\because$ & $\cdots$ & $3.31 E+03$ & $0.00 E+\infty$ & $0.00 E+00$ & $0.00 E+00$ & $1.00 E+00$ & $1.00 E+99$ & 0 & 0 \\
\hline$P_{U-24 z(b)}$ & $\therefore$ & $\cdots$ & & $3.825-03$ & $0.00 E+\infty$ & $0.00 E+00$ & $0.00 E+\infty$ & $2.00 E-03$ & 4.30E-01 & 0 & 0 \\
\hline$A(n-243(b)$ & & 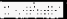 & & 1.99E-01 & $0.00 E+00$ & $0.00 E+\infty$ & $0.00 E+0 D$ & $1.00 E-03$ & $2.30 E-01$ & 0 & 0 \\
\hline $\mathrm{Cm} \cdot 2 \mathrm{a} 3(\mathrm{~b})$ & $\cdots: \cdots$ & & & $5.16 E+01$ & $0.00 E+\infty 0$ & $0.00 E+\infty O$ & $0.00 E+00$ & $1.80 E .02$ & $3.40 E+02$ & 0 & 0 \\
\hline $\mathrm{Cm} \cdot 244$ & $8, \square+1:$ & in & inis & $8.10 E+01$ & $0.00 E+\infty$ & $0.00 E+00$ & $0.00 E+00$ & $1.40 E-01$ & $1.60 E+02$ & 0 & 0 \\
\hline PU-244(b) & $\because$ & : & & $1.77 \mathrm{E}-05$ & $0.00 E+00$ & $0.00 E+\infty 0$ & $0.00 E+00$ & $6.10 E-04$ & $1.30 E-01$ & 0 & 0 \\
\hline $\mathrm{Cm}-245(\mathrm{~b})$ & तi & 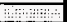 & : & $1.72 E-01$ & $0.00 E+\infty$ & $0.00 E+00$ & $0.00 E * 00$ & $1.30 E-03$ & $2.20 \mathrm{E}-01$ & 0 & 0 \\
\hline$(\mathrm{cm}-246(\mathrm{~b})$ & 8 & and & 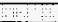 & $3.07 \mathrm{E}-01$ & $0.00 E+\infty$ & $0.00 E+\infty$ & $0.00 E+\infty$ & $1.80 E-03$ & 4.20E.01 & 0 & 0 \\
\hline $\mathrm{Cm}-247(b)$ & 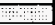 & +1:? & 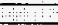 & $9.28 \mathrm{E}-05$ & $0.00 E+\infty 0$ & $0.00 E+\infty 0$ & $0.00 E+\infty 0$ & $5.60 E-04$ & $1.20 E-01$ & 0 & 0 \\
\hline$(\mathrm{m} \cdot 248(\mathrm{~b})$ & $: \quad:$ & & & $4.25 \mathrm{E}-0.3$ & $0.00 E+00$ & $0.00 E+00$ & $0.00 E+\infty$ & $5.10 \equiv-04$ & $1,10 \mathrm{E}-0 t$ & 0 & 0 \\
\hline & & & & & & & & & & Ealkgory 1 & ory 3 \\
\hline & & & & & & & & Sum of the & Fractions $=$ & 0.590156459 & $2.65524 E-C$ \\
\hline
\end{tabular}

Box 3: C3, C4, R4, R5

TRU $<100 \mathrm{nCi} / \mathrm{g}$ 
WHC-SD-NEL-ER-004 Rev. 0

ATTACHMENT III: Chemical Characterization 


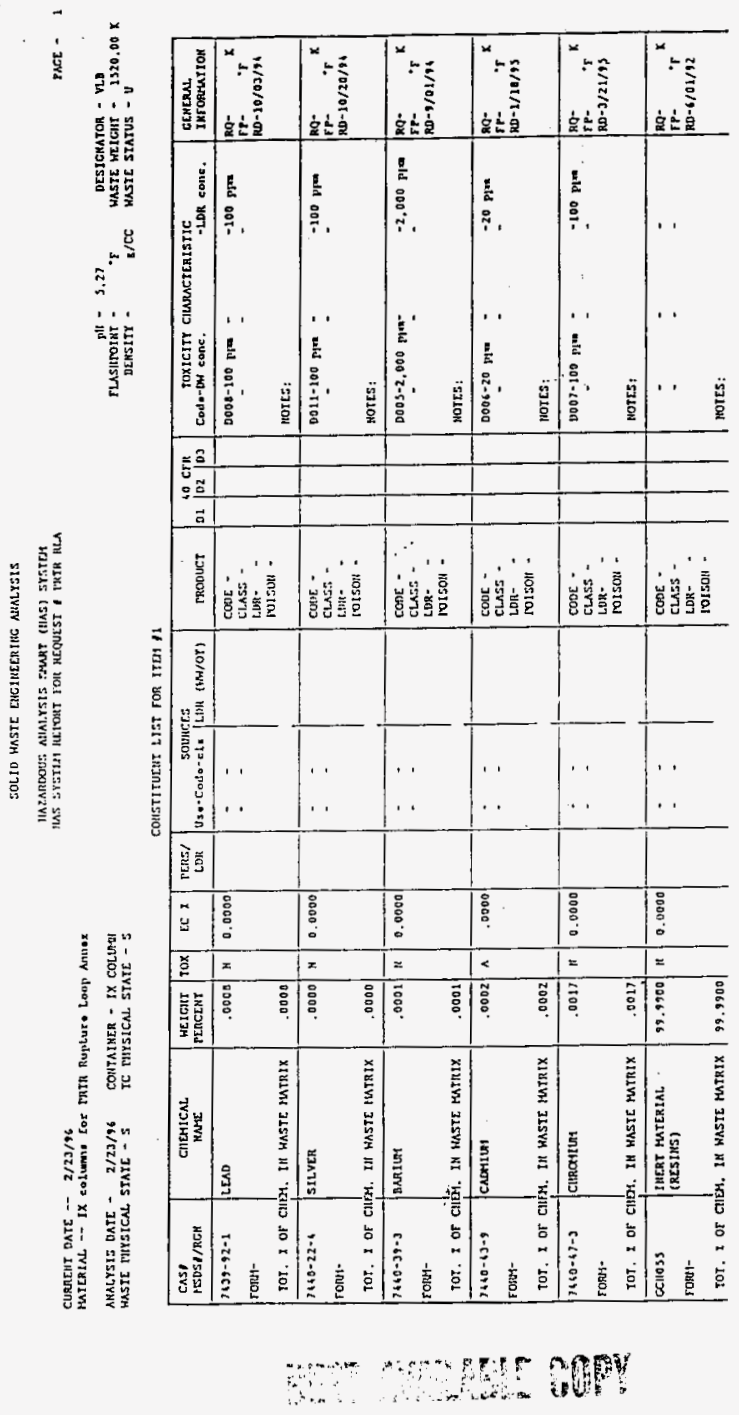




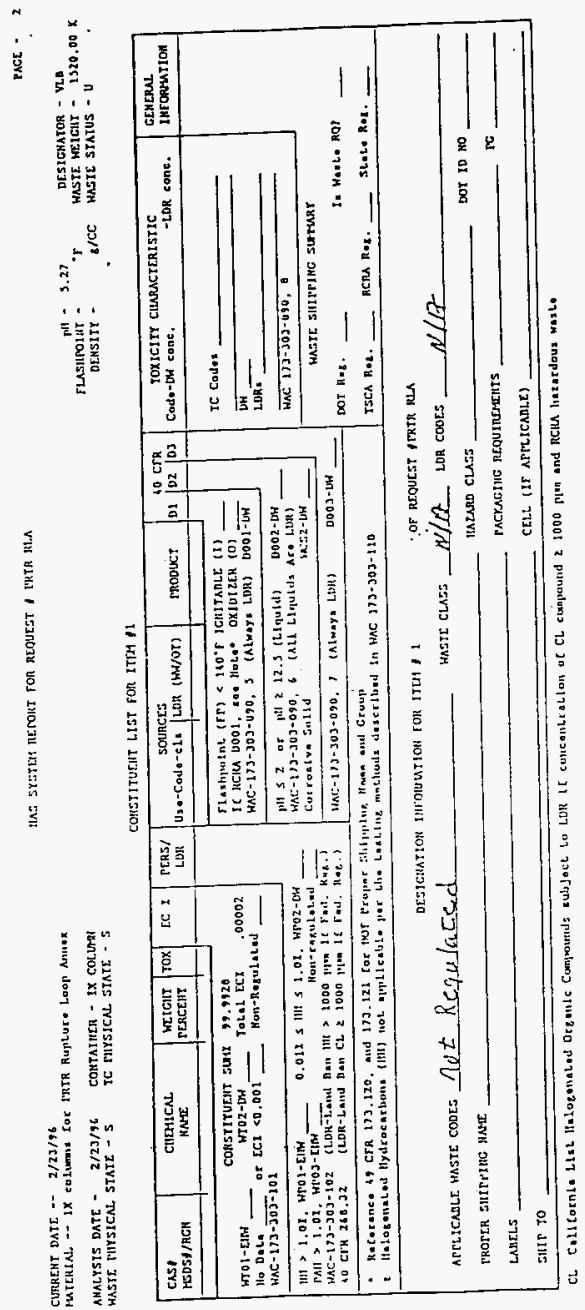

Ber nomere Copt 


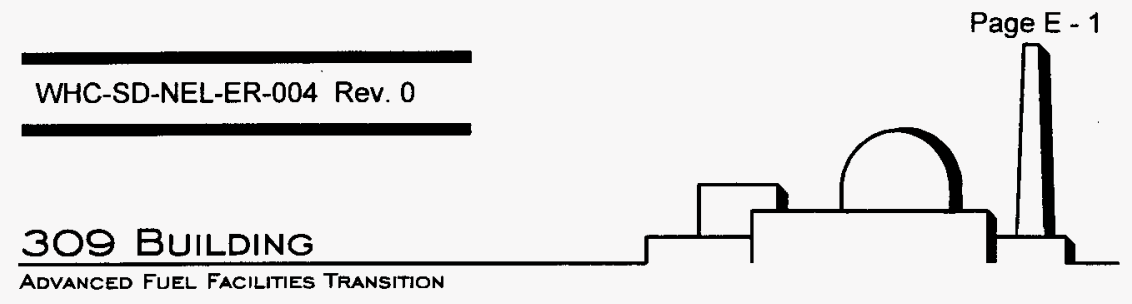

APPENDIX E - WASTE PORTFOLIO 


\section{WASTE CERTIFICATION SUMMARY}

\section{GENERATQR: WASTE TYPE: WSRd NUMBER: REVISION:}

\author{
ADVANCED FUEL FACILITIES TRANSITION \\ SOLID WASTE FROM RUPTURE LOOP ANNEX IX VAULT \\ 100-00, 101-00 \\ REV. 1. APRIL 22, 1996
}

Waste Generating Process Description: The 309 Plutonium Recycle Test Reactor (PRTR) used a contained system for testing called Fuel Element Rupture Test Facility (FERTF) which was a pressurized, light-water-cooled loop, using one of the 85 process tubes within the main, heavywater-cooled PRTR calandria. The FERTF could be operated in a recirculating or once through cooling mode. It was a pilot irradiation facility to test new fuel element designs and new operating regimes. Many of its tests involved testing of pre-defective fuel elements, containing natural uranium and $1 \%$ to $4 \% \mathrm{PuO}_{2}$, with pinhole breaks to study the stability of various defected material under irradiation. The Rupture Loop Annex (RLA) lon Exchanger (IX) Vault design had positions of three active RLAIX columns and storage space for 12 spent RLAIX columns. The operating RLAIX columns were connected in series for removal of the fuel and fission products in the FERTF coolant.

The RLAIX cleanup test loop and the PRTR main cleanup system were both contaminated with fuel residual and fission products. This contamination was filtered out of the system using the $I X$ columns. Sample results from the PRTR IX columns resin indicated that the contents are not Hazardous. Since the cleanup system IX columns in both vaults have similar resin media, similar isotopic material contents are expected.

Physical Characterization: The waste that will be removed from the RLAIX vault will consist of 12 IX columns, 10 of which contain resin; piping, connector heads, jumpers, valving, metal blow down filter, other metal debris, wood, plastic, rubber, and sweepings off of the floor of the RLAIX Vault (dirt, rust, scrap material); equipment used to pump liquids from the IX columns; small quantities of inorganic, nonregulated absorbed liquids; and other materials as described in WSRd $100-00$ and 101-00. Metal materials are made of aluminum, carbon steel, and stainless steel.

The shell and dunnage dimensions for nine of the $\mathrm{IX}$ columns are $0.71 \mathrm{~m}$ diameter and $3.30 \mathrm{~m}$ high. Variations of this type include internal baffle/plate or sparger system with the shell and dunnage constructed of carbon steel. The shell and dunnage dimensions for one of the IX columns are $0.53 \mathrm{~m}$ diameter and $3.35 \mathrm{~m}$ high. The $\mathrm{IX}$ column and dunnage is constructed of carbon steel. There are two empty IX columns one constructed of stainless steel and the other one constructed of aluminum. The aluminum IX column and dunnage is $0.457 \mathrm{~m}$ diameter and $2.692 \mathrm{~m}$ high and the stainless steel IX column and dunnage is $0.762 \mathrm{~m}$ diameter and $2.692 \mathrm{~m}$ high . Please see attachments for drawings.

Radiological Characterization: The IX columns received a Gamma analysis with results showing ${ }^{60} \mathrm{Co},{ }^{137} \mathrm{Cs},{ }^{90} \mathrm{Sr}$. The value for ${ }^{90} \mathrm{Sr}$ was derived from a ratio of ${ }^{90} \mathrm{Sr}$ to ${ }^{137} \mathrm{Cs}$ based on laboratory analysis of PRTR IX columns. The TRU distribution is a results of a PNL assay and the decay calculations from the documented original fuel burn in the reactor. The resulting isotopic distributions consists of ${ }^{241} \mathrm{Am},{ }^{237} \mathrm{~Np},{ }^{233} \mathrm{~Pa},{ }^{234} \mathrm{U},{ }^{235} \mathrm{U},{ }^{236} \mathrm{U},{ }^{238} \mathrm{U},{ }^{238} \mathrm{Pu},{ }^{239} \mathrm{Pu},{ }^{240} \mathrm{PU},{ }^{241} \mathrm{Pu}$, and ${ }^{242} \mathrm{PU}$. This is a industrial standard method for isotopic distribution. Please see the attachment for the radiological inventory.

The IX columns are segregated into three boxes and the curies have been totaled for the point source and category calculations. Please see the attachment for category calculations. Four IX columns are placed in each 12.23 cubic meter box $\left(6^{\prime} \times 6^{\prime} \times 12^{\prime}\right)$. Two of the boxes are category 3 and one is category 1 . Box 1 contains IX columns L1, L3, R1, and R2 (catllI). Box 2 contains IX 
columns $\mathrm{L} 2, \mathrm{~L} 4, \mathrm{C} 2$, and $\mathrm{R} 3$ (catlII). Box 3 contains IX columns C3, C4, R4, R5/RLIX-1, and other debris taken from the RLAIX Vault. All waste added to box 3 that is not an IX column contains less than $1 \%$ of the IX columns activity and therefore has no activity contribution to the boX.

Chemical Characterization: The cation RLAIX column (RLIX-1) contains an AMBERLITE ${ }^{\otimes}$ IRN163 resin. The mixed bed RLAIX column (RLIX-2) contains an AMBERLITE ${ }^{\circledR}$ IRN-154 resin, which is a combination of AMBERLITE ${ }^{\star}$ IRN-163 and AMBERLITE ${ }^{\oplus}$ IRN-78 resins. The deoxygenator (RLIX-3 contains a Duolite S-10 and AMBERLITE ${ }^{\circledR}$ IRN-154 mixture. These resins are not regulated as dangerous waste. Process knowledge tells us that only water was allowed in the reactor and process loops, and with this knowledge we would only look for heavy metals from the crud products of the system. The analysis from the PRTR IX column resins was used as process knowledge for the RLAIX columns due to the similarity of the resins, water process, and common accidental test failure of the total system. Please see attachments of MSDS and analysis.

AMBERLITE ${ }^{\oplus}$ is a trademark of Rohm and Haas Company or one of its subsidiaries or affiliates.

Waste Designation: The analysis that was done on the PRTR IX column resins was used to designate the RLAIX resins. The results show that the resin is not regulated as dangerous waste. Please see the attachment for the designation.

Segregation: Segregation of the waste into the proper containers will be performed using work procedure 309-WP-96-002, "Rupture Loop Annex lon Exchange (RLAIX) Vault Cleanout." This procedure will also ensure the packaging requirements are met.

Packaging: The IX columns will be packaged in three Type $A$ metal boxes. The reference for the packaging is WHC-SD-TP-SEP-047, "Safety Evaluation for Packaging for Onsite Transfer of 12 lon Exchange Columns."

The waste as packaged is classified as low-level waste. IX columns placed in boxes 1 and 2 will be stabilized with grout to meet the requirements for category 3 waste disposal. The grout formulation will be the same used for the first shipment of IX columns from PRTR for disposal at Hanford's burial grounds $\left(118 \mathrm{lb} / \mathrm{ft}^{3}\right)$. It is not necessary to stabilize box 3 , since it is category 1 waste. The distribution of the IX columns, curies, and weight are as follows:

Box 1: IX column L3, L1, R1; and R2

Total curies $=3.77$

L3: 3800 lbs ( 33 cubic feet; flled with resin)

L1: 3800 lbs ( 33 cubic feet; filied with resin)

R1: 3800 lbs (33 cubic feet; filled with resin)

R2: 3800 lbs ( 33 cubic feet; filled with resin)

Grout: 35,400 lbs (300 cubic feet; $118 \mathrm{lbs} /$ cubic foot)

Estimated Contents Weight: $50,600 \mathrm{lbs}$

Box: 4000 lbs (432 cubic feet)

ESTIMATED TOTAL PACKAGE WEIGHT: 54,600 bs

Box 2: 1X columns R3, C2, L2, and L4

Total curies $=2.35$

R3: 3800 lbs ( 33 cubic feet; filled with resin)

C2: 1800 lbs (18 cubic feet; filled with resin)

L2: 3800 lbs ( 33 cubic feet; filled with resin)

L4: 3800 lbs ( 33 cubic feet; filled with resin)

Grout: 37200 lbs ( 315 cubic feet; 118 lbs/cubic foot) 
Estimated Contents Weight: 50,400 lbs

Box: 4000 lbs ( 432 cubic feet)

ESTIMATED TOTAL PACKAGE WEIGHT: $54,400 \mathrm{lbS}$

Box 3: IX columns C3, C4, R4, and R5/RLIX-1

Total curies $=0.0442$

C3: 530 lbs (empty: fill with grout)

C4: 180 lbs (empty: fill with grout)

R4: 3800 lbs ( 33 cubic feet; filled with resin)

R5/RLIX-1: 3800 lbs ( 33 cubic feet; filled with resin)

Debris added will be insignificant contribution to the weight.

Grout: 43200 lbs (366 cubic feet; 118 lbs/cubic foot))

Estimated Contents Weight: $51,510 \mathrm{lbs}$

Box: 4000 lbs (432 cubic feet)

ESTIMATED TOTAL PACKAGE WEIGHT: 55,510 LBS

A copy of the characterization is attached.

All waste in boxes 1 and 2 will have to be encased in at least two inches of grout to meet stabilization requirements. No aluminum will be in contact with the grout used for stabilization. IX column $\mathrm{C} 4$ is the only one made of aluminum or with aluminum dunnage. Since IX column C4 will be in box 3 , it will not be in contact with grout required for stabilization.

The maximum free void space in each IX column that is filled with resin is 4.56 cubic feet, based on process knowledge. This calculates to be a total free void space in each $6^{\prime} \times 6^{\prime} \times 12^{\prime}\left(432 \mathrm{ft}^{3}\right)$ box of 4.22 percent. This is below the maximum free void space limit of $10 \%$. Since the resin chambers in IX columns $\mathrm{C} 3$ and $\mathrm{C} 4$ are empty of resin, these void spaces will be filled with the same type of grout as used on boxes 1 and 2 . Void space filler for box 3 will also be filled with the same type of grout.

Plastic liners will not be used to line the boxes. All waste in boxes 1, 2, and 3 will be encased in at least two inches of grout between the waste and the inner surface of each box to provide one containment barrier. The box will be the other containment barrier.

The IX columns must have as much liquid removed as is reasonably achievable. The only IX columns that will have liquid remaining after pumping will be the IX columns with spargers. Based on process knowledge, the maximum free liquid that will remain in a given sparger IX column will be 7 gallons. Polymeric sorbent will be added to the tops of these IX columns in sufficient amounts to sorb twice the amount of liquid that is potentially present. The IX columns will then be oriented horizontally to allow all the liquid to drain into the sorbent.

Boxes 1 and 2 must allow for the off-gassing of hydrogen that is generated in the IX columns. The fill pipe of each IX column must not be sealed. The grout and the Type A box will allow the diffusion of the hydrogen. Thus, there will be no gas pressurization problems.

Waste Minimization: Minimization of waste through use of non-regulated products or materials is the preferred waste management tool. Source reduction for dangerous products/chemicals has been implemented. Source reduction, recycling, and treatment opportunities for all waste streams including sanitary, dangerous, radioactive, and mixed has been implemented.

Please see attachments: 


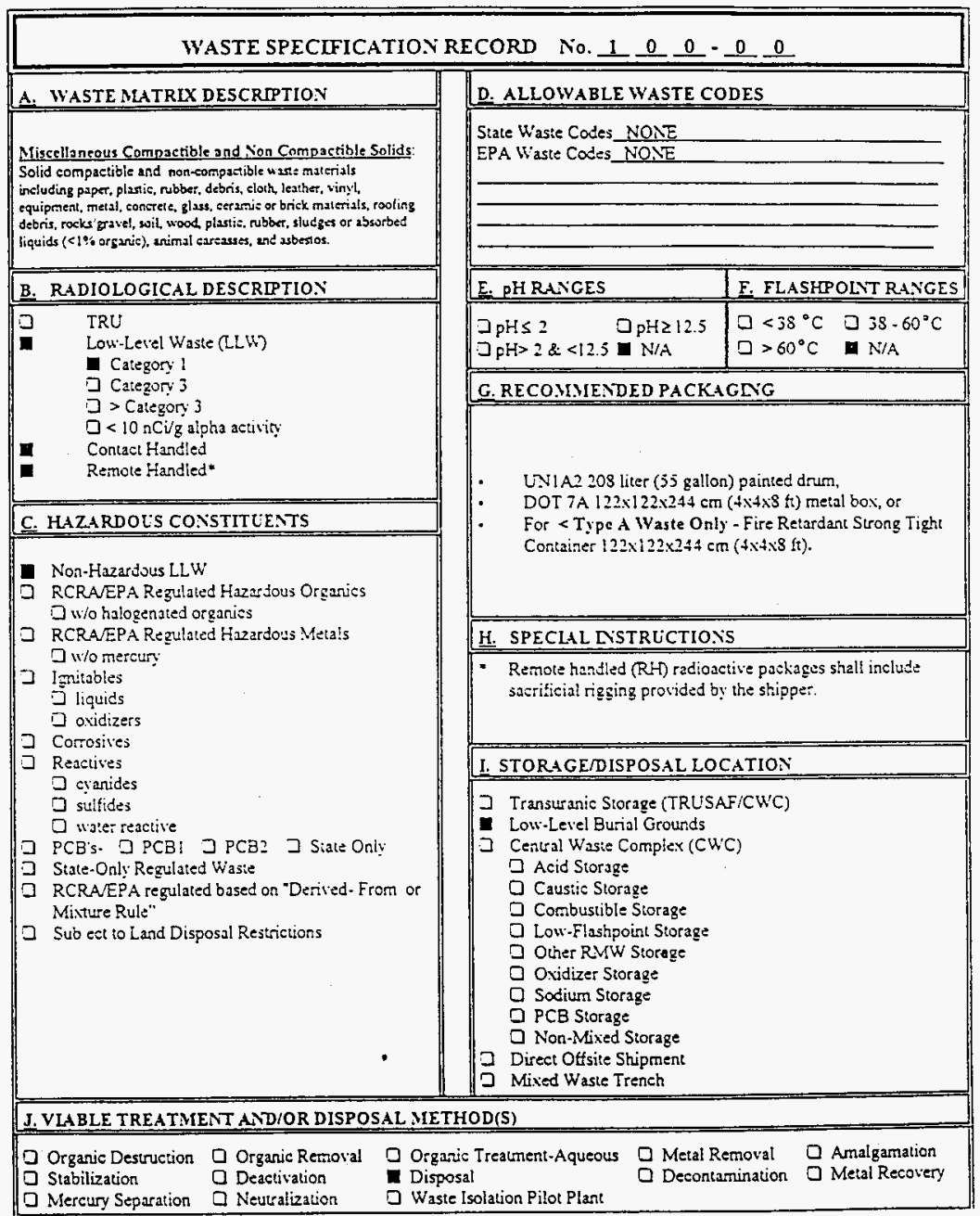




\begin{tabular}{|c|c|c|}
\hline \multicolumn{3}{|c|}{ WVASTE SPECIFICATIOY RECORD No. $10,1.0$} \\
\hline A. WASTE MLATRCY DESCRIPTIOY & \multicolumn{2}{|c|}{ D. ALLOWABLE WASTE CODES } \\
\hline 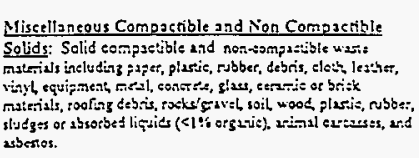 & \multicolumn{2}{|l|}{$\begin{array}{l}\text { State Waste Codes NONE } \\
\text { EPA Wasie Codes NONE }\end{array}$} \\
\hline B. RADIOLOGICAL DESCRIPTIOY & E. PG R.AYCES & E. FLASHPONI RLIGES \\
\hline \multirow{3}{*}{ 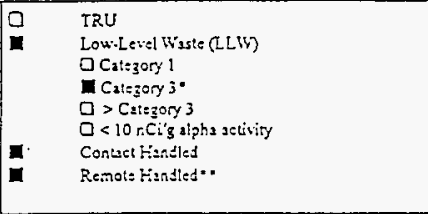 } & \multicolumn{2}{|l|}{$\begin{array}{ll}\square p H \leq 2 & \square p \mathrm{pH} z 12.5 \\
\square \mathrm{pH}>2 \&<12.5 \quad \square \mathrm{N} / \mathrm{A}\end{array}$} \\
\hline & \multicolumn{2}{|c|}{ G. RECO.MIENDED PACKAGNG } \\
\hline & \multirow{3}{*}{\multicolumn{2}{|c|}{ 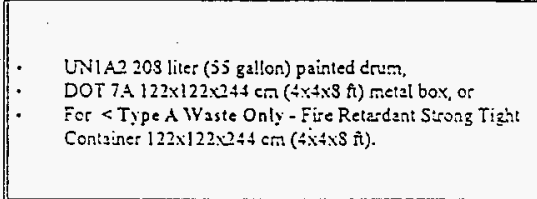 }} \\
\hline C. HAZARDOUS CONSTITUENTS & & \\
\hline 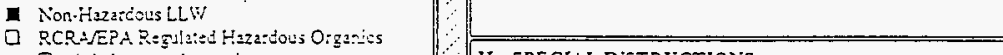 & & \\
\hline O w/o haloz=nsied orgunes & \multicolumn{2}{|l|}{ H. SPECLAL NSTRUCTIONS } \\
\hline 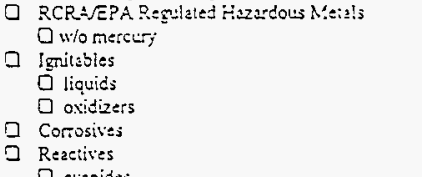 & \multicolumn{2}{|c|}{ 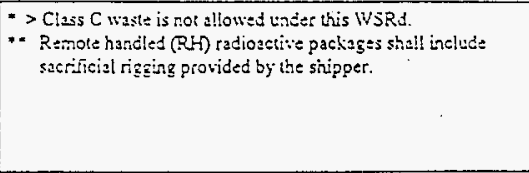 } \\
\hline 0 suifides & \multicolumn{2}{|c|}{ I. STORACEIDISPOSAL LOCATION } \\
\hline 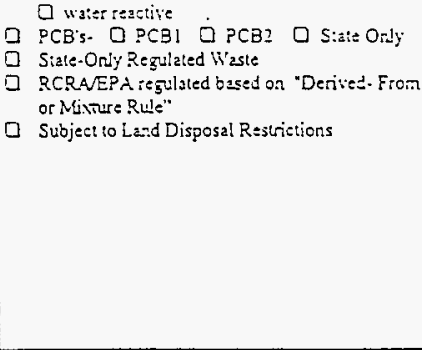 & \multicolumn{2}{|c|}{ 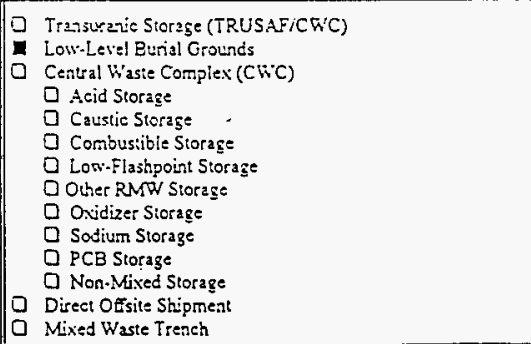 } \\
\hline \multicolumn{3}{|c|}{ J. VLABLE TREATMENT AND/OR DISPOSAL METHOD(S) } \\
\hline \multicolumn{3}{|c|}{ 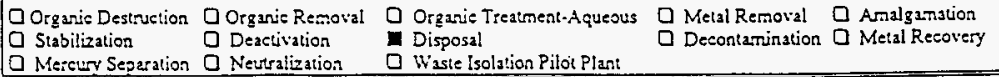 } \\
\hline
\end{tabular}




\begin{tabular}{|c|c|}
\hline $\begin{array}{l}\text { GENERATION } \\
\text { LOCATION }\end{array}$ & Rupture Loop Annex Ion Exchanger Vault at the 309 Building \\
\hline $\begin{array}{l}\text { PHYSICAL } \\
\text { DESCRIPTION }\end{array}$ & $\begin{array}{l}\text { Ion exchangers R4, R5/RLIX-1, C3, and C4, with resin and absorbed liquid. } \\
\text { Contaminated equipment used in cleanup operation. } \\
\text { Plastic, tumble weeds, piping, connsctor heads, jumpers, valving, fitter with metal housing. wooden ladder, } \\
\text { contained floor sweepings, and absorbed liquid from vault. }\end{array}$ \\
\hline $\begin{array}{l}\text { RADIOLOGICAL } \\
\text { CHARACTERISTICS }\end{array}$ & Category 1 Low-Level Waste \\
\hline $\begin{array}{l}\text { DANGEROUS } \\
\text { CHARACTERISTICS }\end{array}$ & Non-Hazardous \\
\hline $\begin{array}{l}\text { DOT HAZARD } \\
\text { CLASSIFICATION }\end{array}$ & Hazard Class 7; Radioactive material. n.o.s. \\
\hline $\begin{array}{l}\text { PACKAGING } \\
\text { REQUIREMENTS }\end{array}$ & $\begin{array}{l}\text { Safety Evaluation for Packaging and Hanford Site requirements: } \\
\text { 1) USA DOT 7A Type A. } 6 \times 6 \times 12 \mathrm{ft} \text { metal box, Capital Industries part } 50710-0710-1420-0187 \text {. } \\
\text { 2) Void fill the resin chambers of ion exchangers C3 and C4 with grout. } \\
\text { Using grout as a void filler, pour a layer of at least two inches of grout in the bottom and adhere two inch } \\
\text { 3) standoffs with waterstops to the interior sides of the box prior to placing waste in the box, atter the box is filled } \\
\text { with waste, fill the void spaces in a minimum of three lifts; seal the grout ports. } \\
\text { Remove liquid from ion exchanger R5/RLIX-1 to the maximum extent practicable. } \\
\text { 4) Add a minimum of .5 gallons of RADSORB to ion exchangers R4 and R5/RLIX-1 through the resin fill ports. } \\
\text { 5) Non-combustible, non-regulated material may be used as necessary to brace the waste to prevent shifting } \\
\text { Best Management Practice: } \\
\text { 1) and loss of containment integrity during packing, transportation, and storage. }\end{array}$ \\
\hline $\begin{array}{l}\text { MARKING AND } \\
\text { LABELING } \\
\text { REQUIREMENTS }\end{array}$ & 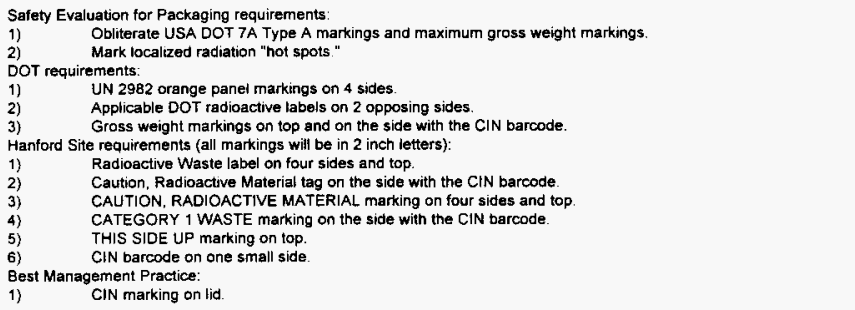 \\
\hline $\begin{array}{l}\text { TRANSPORTATION } \\
\text { REQUIREMENTS }\end{array}$ & 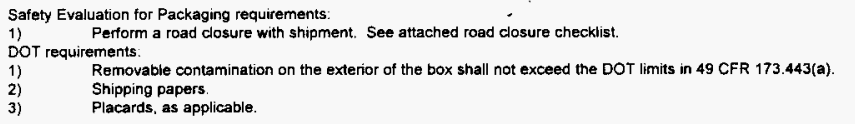 \\
\hline $\begin{array}{l}\text { SPECIAL } \\
\text { INSTRUCTIONS }\end{array}$ & $\begin{array}{l}\text { Safety Evaluation for Packaging requirements: } \\
\text { I) Install sacrificial rigging capable of hoisting } 60,000 \mathrm{lb} \text {, to be shipped in a ready to hoist configuration, } \\
\text { approachable for hook up from the side of the box with the lowest radiation levels. } \\
\text { The minimum gross weight of the box is } 40,000 \mathrm{Ib} \text {. The maximum gross weight of the box is } 60,000 \mathrm{lb} \text {. } \\
\text { Install the box lid according to the manufacturers closure instructions. Tamper-indicating features are not } \\
\text { required. } \\
\text { 3) Grout must be cured to } 1000 \text { psi test strength prior to movement of the box. } \\
\text { 4) Submit complete pre-shipment portiolio to Acceptance Services. } \\
\text { Hanford Site requirements: } \\
\text { 1) }\end{array}$ \\
\hline
\end{tabular}




\begin{tabular}{|l|ll|}
\hline $\begin{array}{l}\text { TREATMENT } \\
\text { STORAGE DISPOSAL } \\
\text { LOCATION(S) }\end{array}$ & 1) & Disposal at Hanford Site Low-Level Burial Grounds \\
\hline $\begin{array}{l}\text { REFERENCE } \\
\text { INFORMATION }\end{array}$ & 1) & $\begin{array}{l}\text { 309 Building Waste Management Program Plan, 309-WM-96-00t } \\
\text { Safety Evaluation for Packaging for Onsite Transfer of Twelve lon Exchange Columns, WHC-SD-TP-SEP-047 } \\
\text { Waste Centification Summary: SOLIO WASTE FROM RUPTURE LOOP ANNEX IX VAULT. Rev. } 1 \\
\text { Waste Specification Record No. 100-00 } \\
\text { Hanford Site Solid Waste Acceptance Criteria, WHC-EP-0063-4 }\end{array}$ \\
\hline
\end{tabular}




\section{Waste Stream Requirements Summary No. RLA-IXV-02 D}

\begin{tabular}{|c|c|}
\hline $\begin{array}{l}\text { GENERATION } \\
\text { LOCATION }\end{array}$ & Rupture Loop Annex Ion Exchanger Vault at the 309 Building \\
\hline $\begin{array}{l}\text { PHYSICAL } \\
\text { DESCRIPTION }\end{array}$ & $\begin{array}{l}\text { Ion exchangers identified as R1, R2, R3, L1, L2, L3, L4 and C2, with resin and absorbed } \\
\text { liquid. } \\
\text { Contaminated tubing and fasteners used to pump liquid from the ion exchangers. }\end{array}$ \\
\hline $\begin{array}{l}\text { RADIOLOGICAL } \\
\text { CHARACTERISTICS }\end{array}$ & Category 3 Low-Level Waste \\
\hline $\begin{array}{l}\text { DANGEROUS } \\
\text { CHARACTERISTICS }\end{array}$ & Non-Hazardous \\
\hline $\begin{array}{l}\text { DOT HAZARD } \\
\text { CLASSIFICATION }\end{array}$ & Hazard Class 7; Radioactive material, n.o.s. \\
\hline $\begin{array}{l}\text { PACKAGING } \\
\text { REQUIREMENTS }\end{array}$ & $\begin{array}{l}\text { Safety Evaluation for Packaging and Hanford Site requirements: } \\
\text { 1) USA DOT 7A Type A, } 6 \times 6 \times 12 \mathrm{ft} \text { metal box, Capital Industries part S } 0710-0710-1420 \text { - } \\
0187 \text {. } \\
\text { Using Grout Mix Number Four as a stabalizer, pour a layer of at least two inches of grout } \\
\text { in the bottom and adhere two inch standoffs with waterstops to the interior sides of the } \\
\text { box prior to placing waste in the box; after the box is filied with waste, fill the void spaces } \\
\text { in a minimum of three lifts; seal the grout ports. } \\
\text { Remove tiquid from ion exchangers R1, R2, R3, L1, L2, and L3 to the maximum extent } \\
\text { practicable. } \\
\text { Add a minimum of . } 5 \text { galions of RADSORB to ion exchangers R4 and R5/RLIX-1 through } \\
\text { the resin fill ports. } \\
\text { 4) } \\
\text { Best Management Practice: } \\
\text { 1) Non-combustible, non-regulated material may be used as necessary to brace the waste } \\
\text { to prevent shifting and loss of containment integrity during packing, transportation, and } \\
\text { storage. }\end{array}$ \\
\hline $\begin{array}{l}\text { MARKING AND } \\
\text { LABELING } \\
\text { REQUIREMENTS }\end{array}$ & 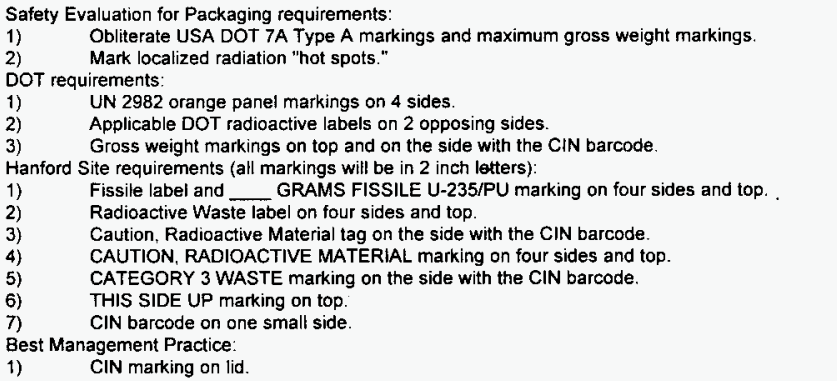 \\
\hline
\end{tabular}




\begin{tabular}{|c|c|}
\hline $\begin{array}{l}\text { TRANSPORTATION } \\
\text { REQUIREMENTS }\end{array}$ & $\begin{array}{l}\text { Safety Evaluation for Packaging requirements: } \\
\text { 1) Perform a road closure with shipment. See attached road closure checklist. } \\
\text { DOT requirements: } \\
\text { 1) Removable contamination on the exterior of the box shall not exceed the DOT limits in } 49 \\
\text { CFR } 173.443(a) . \\
\text { 2) Shipping papers. } \\
\text { 3) Placards, as applicable. }\end{array}$ \\
\hline $\begin{array}{l}\text { SPECIAL } \\
\text { INSTRUCTIONS }\end{array}$ & $\begin{array}{l}\text { Safety Evaluation for Packaging requirements: } \\
\text { 1) lon exchangers } L 1, L 3, R 1 \text {, and } R 2 \text { will be packaged together. Ion exchangers } L 2, L 4 \text {, } \\
C 2 \text {, and } R 3 \text { will be packaged together. } \\
\text { Install sacrificial rigging capable of hoisting } 60,000 \mathrm{lb} \text {, to be shipped in a ready to hoist } \\
\text { configuration, approachable for hook up from the side of the box with the lowest radiation } \\
\text { levels. } \\
\text { 2) The minimum gross weight of the box is } 40,000 \mathrm{lb} \text {. The maximum gross weight of the } \\
\text { box is } 60,000 \mathrm{lb} \text {. } \\
\text { Install the box lid according to the manufacturers closure instructions. Tamper-indicating } \\
\text { features are not required. } \\
\text { 3) Grout must be cured to } 1000 \text { psi test strength prior to movement of the box. } \\
\text { 4) Submit complete pre-shipment portfolio to Acceptance Services. } \\
\text { 5) }\end{array}$ \\
\hline $\begin{array}{l}\text { TREATMENT } \\
\text { STORAGE } \\
\text { DISPOSAL } \\
\text { LOCATION(S) }\end{array}$ & Disposal at Hanford Site Low-Level Burial Grounds \\
\hline $\begin{array}{l}\text { REFERENCE } \\
\text { INFORMATION }\end{array}$ & $\begin{array}{l}309 \text { Building Waste Management Program Plan, 309-WM-96-001 } \\
\text { Safety Evaluation for Packaging for Onsite Transfer of Twelve lon Exchange Columns, } \\
\text { WHC-SD-TP-SEP-047 } \\
\text { Waste Certification Summary: SOLID WASTE FROM RUPTURE LOOP ANNEX iX } \\
\text { VAULT, Rev. } 1 \\
\text { Waste Specification Record No. 100-01 } \\
\text { Hanford Site Solid Waste Acceptance Criteria, WHC-EP-0063-4 } \\
\text { Internal Memo. B. A. Mayancsik to E. J. Bitten, PLUTONIUM RECYCLE TEST FACILITY } \\
\text { ION EXCHANGE COLUMNS STABALIZATION, dated May 6, } 1996\end{array}$ \\
\hline
\end{tabular}




\section{WASTE CERTIFICATION SUMMARY}

GENERATOR:

WASTE TYPE:

WSRA NUMBER: REVISION:

\author{
ADVANCED FUEL FACILITIES TRANSITION \\ STEP-OFF PAD WASTE AND LOW-LEVEL DEBRIS FROM \\ PRTR DEACTIVATION \\ 100-00A \\ REV. 1. MAY 2, 1996
}

Waste Generating Process Description: The 309 Plutonium Recycle Test Reactor (PRTR) used a contained system for testing called Fuel Element Rupture Test Facility (FERTF) which was a pressurized, light-water-cooled loop, using one of the 85 process tubes within the main, heavywater-cooled PRTR calandria. The FERTF could be operated in a recirculating or once through cooling mode. It was a pilot irradiation facility to test new fuel element designs and new operating regimes. Many of its tests involved testing of pre-defective fuel elements, containing natural uranium and $1 \%$ to $4 \% \mathrm{PuO}_{2}$, with pinhole breaks to study the stability of various defected material under irradiation. The PRTR designed positions for two vaults for spent ion exchange columns. The operating columns were connected in series for removal of the fuel and fission products in the FERTF coolant. The Rupture Loop Annex (RLAIX) contained columns connected in series for removal of products from the test loop.

The waste that will be created under this Waste Certification Summary will be from the process of removing the reactor hardware and miscellaneous materials that are left in the reactor facility. All characterization information and process knowledge is documented in WHC-SD-NEL-ER-002.

Physical Characterization: The waste consists of paper, cloth, rubber, plastic, metal, wood and leather. The forms of waste could be small pieces of equipment and reactor system components, tools, tygon tubing copper wire, metal signs, mazalan cloth, rubber gloves, shoe covers, mask cartridges, leather gloves, mop heads and handles brooms, tape, cardboard, and plastic (bottlesbags), glass (bottles and sampling equipment), filters, sampling equipment, sweepings (dirt, rust, scrap material); small quantities of inorganic, nonregulated absorbed liquids; empty Amercoat Waterborne Acrylic, Product \#220 (MSDS 25821) paint containers; painting equipment with less than $10 \%$ Amercoat paint content; and other materials as described in WSRd 100-00. There will be no free liquids.

Radiological Characterization: The characterization is based on process knowledge from the fuel burn up analysis and decay calculations. A gamma energy, alpha energy and beta analysis was performed on the IX columns and vault water to confirm the process knowledge. Through the use of process knowledge and analysis, decay calculations can be used to derive all of the isotopes that would be present. The following are the isotopes of concern: ${ }^{234} \mathrm{U},{ }^{235} \mathrm{U},{ }^{236} \mathrm{U},{ }^{238} \mathrm{U}$, ${ }^{241} \mathrm{Am},{ }^{233} \mathrm{~Pa},{ }^{237} \mathrm{~Np},{ }^{238} \mathrm{Pu},{ }^{239} \mathrm{Pu},{ }^{240} \mathrm{PU},{ }^{241} \mathrm{Pu},{ }^{242} \mathrm{Pu},{ }^{90} \mathrm{Sr},{ }^{60} \mathrm{Co},{ }^{137} \mathrm{Cs}$ and trace amounts of ${ }^{14} \mathrm{C}$ and ${ }^{3} \mathrm{H}$. The other isotopes are either less than one percent of the total curies, not listed on the category table or less than one percent of the category 1 limits. Radiological analysis is attached as appendix $A$. The containers will contain low level category 1 waste. Radiological characterization of each container for disposal will be done either by dose to curie and scaling factors or by assay and scaling factors.

Chemical Characterization: The waste consists of reactor components, personal protective equipment (PPE), and solid waste material contaminated by the reactor or reactor water which through process knowledge and chemical analysis contained no dangerous/hazardous material. See appendix $B$ for analysis.

Empty Amercoat Waterborne Acrylic, Product \#220 (MSDS 25821) paint containers and painting equipment with less than $10 \%$ Amercoat paint content will be in the waste stream. 
Waste Designation: All materials used in the deactivation and packaging of the facilities waste will be pre-designated in accordance with the Washington State Dangerous Waste Regulations Chapter 173-303.

A pre-designation of the Amercoat, listed above, was performed. In the quantities stated above, the Amercoat waste is non-regulated. Reference appendix B.

Segregation: Segregation of the waste into the proper containers will be performed using work procedure 309-WM-96-003, "Low-Level Waste Packing Procedures."

Packaging: The low-level waste debris will be packaged in UN1A2 208 liter ( 55 gallon) painted drums, DOT 7A $122 \times 122 \times 244 \mathrm{~cm}(4 \times 4 \times 8 \mathrm{ft})$ metal boxes, and, for < Type A waste only, $122 \times 122 \times 244 \mathrm{~cm}(4 \times 4 \times 8 \mathrm{ft})$ Fire Retardant Strong Tight Containers, as allowed per WSRd 100-00

Containers with Department of Transportation (DOT) Type A quantities of waste will be lined with a ten mil polyethylene reinforced liner. Containers with DOT Limited Quantity and Low Specific Activity quantities may or may not be lined per Hanford Site Solid Waste Acceptance Criteria chapter 3 section 3.7 section 3.7 .1 .2 .5 .b. Containers with a liner will have all sharp edges and corners padded to protect the liner. The liner will be pigtailed and sealed with plastic reinforced tape. Hanford approved void space filler will be added to the containers, if needed, to assure less than $10 \%$ free void space. Plastic or glass containers that previously contained liquid will be drained and filled with RADSORB.

Waste Minimization: Waste minimization during decommissioning is accomplished through the use of non-regulated products or materials. The other methods are implementation of source reduction, recycling, and treatment opportunities for all waste streams including sanitary, dangerous, radioactive and mixed.

Please see attachment: 


\begin{tabular}{|c|c|c|}
\hline \multicolumn{3}{|c|}{309 Waste Stream Requirements Summary } \\
\hline $\begin{array}{l}\text { GENERATION } \\
\text { LOCATION }\end{array}$ & & $\begin{array}{l}\text { Rooms and areas associated with and containing the PRTR systems in the } 309 \text { Building } \\
\text { and on the } 309 \text { Building grounds. }\end{array}$ \\
\hline $\begin{array}{l}\text { PHYSICAL } \\
\text { DESCRIPTION }\end{array}$ & 1) & $\begin{array}{l}\text { The waste consists of paper, cloth, rubber, plastic, metal, wood and leather. The forms of } \\
\text { waste could be small pieces of equipment and reactor system components, tools, tygon } \\
\text { tubing copper wire, metal signs, mazalan cloth, rubber gloves, shoe covers, mask } \\
\text { cartridges, leather gloves, mop heads and handies brooms, tape, cardboard, and plastic } \\
\text { (bottles-bags), filters, sampling equipment, sweepings (dirt, rust, scrap material); small } \\
\text { quantities of inorganic, nonregulated absorbed liquids; and other materials as described } \\
\text { in WSRd } 100-00 \text {. } \\
\text { Waste containing Amercoat paint, limited to empty paint containers and other waste in } \\
\text { which the Amercoat paint makes up }<10 \% \text { of the waste matrix. }\end{array}$ \\
\hline $\begin{array}{l}\text { RADIOLOGICAL } \\
\text { CHARACTERISTICS }\end{array}$ & 1) & Category 1 Low-Level Waste \\
\hline $\begin{array}{l}\text { DANGEROUS } \\
\text { CHARACTERISTICS }\end{array}$ & 1) & Non-Hazardous \\
\hline $\begin{array}{l}\text { DOT HAZARD } \\
\text { CLASSIFICATION }\end{array}$ & $\begin{array}{l}\text { 1) } \\
\text { 2) } \\
\text { 3) }\end{array}$ & $\begin{array}{l}\text { Hazard Class 7: Radioactive material, n.o.s. } \\
\text { Hazard Class 7; Radioactive material, LSA, n.o.s. } \\
\text { Hazard Class 7; Radioactive material, excepted package-limited quantity of material. }\end{array}$ \\
\hline $\begin{array}{l}\text { PACKAGING } \\
\text { REQUIREMENTS }\end{array}$ & $\begin{array}{r}\text { Han } \\
\text { 1) } \\
\text { 2) } \\
\text { 3) } \\
\text { 4) } \\
\text { 5) } \\
\text { DO } \\
\text { 1) } \\
\text { DO } \\
\text { 1) } \\
\text { DO } \\
\text { 1) } \\
\text { 2) }\end{array}$ & 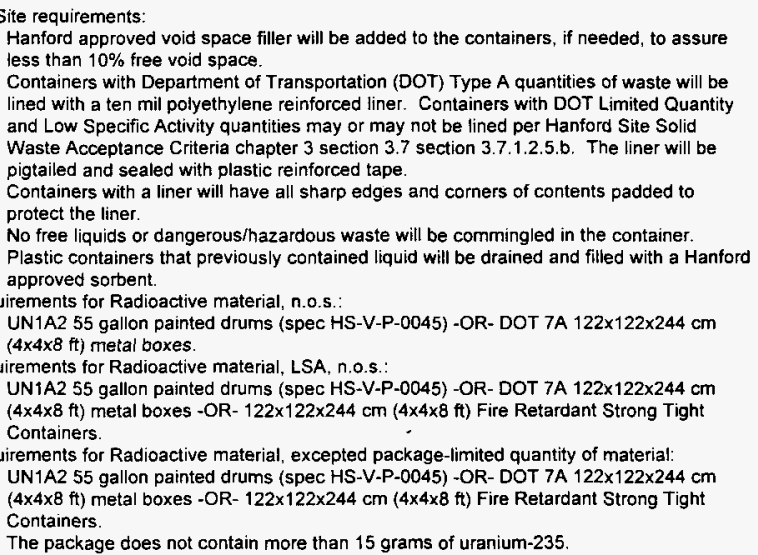 \\
\hline
\end{tabular}




\section{Waste Stream Requirements Summary}

\begin{tabular}{|c|c|}
\hline $\begin{array}{l}\text { MARKING AND } \\
\text { LABELING } \\
\text { REQUIREMENTS }\end{array}$ & 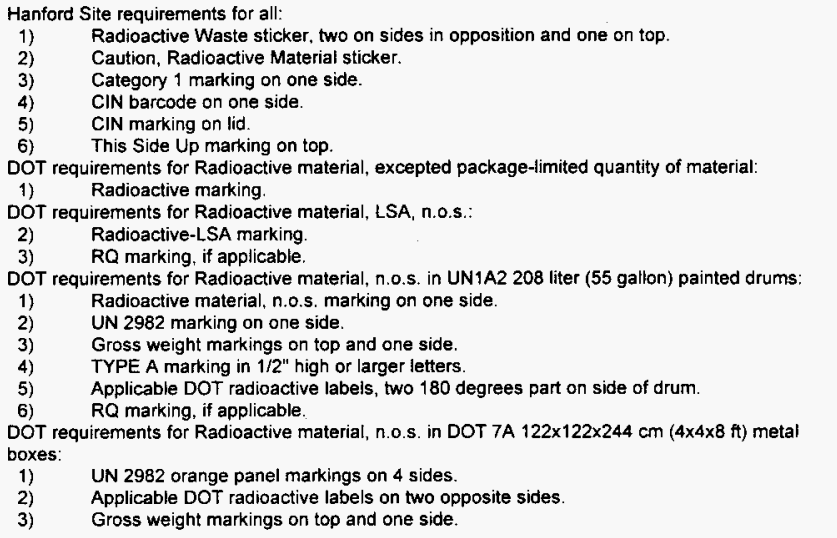 \\
\hline $\begin{array}{l}\text { TRANSPORTATION } \\
\text { REQUIREMENTS }\end{array}$ & 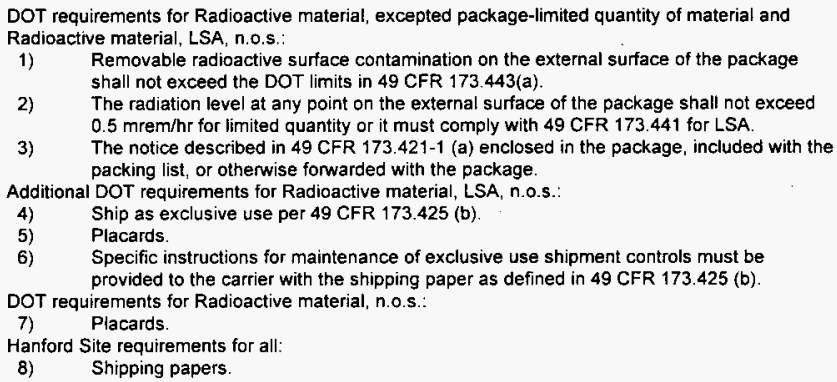 \\
\hline $\begin{array}{l}\text { SPECIAL } \\
\text { INSTRUCTIONS }\end{array}$ & $\begin{array}{l}\text { Hanford Site requirements for all: } \\
\text { 1) Radiologically characterize each container using dose to curie and scaling factors or } \\
\text { assay and scaling factors. } \\
\text { 2) }\end{array}$ \\
\hline $\begin{array}{l}\text { TREATMENT } \\
\text { STORAGE } \\
\text { DISPOSAL } \\
\text { LOCATION(S) }\end{array}$ & Disposal at Hanford Site Low-Level Burial Grounds \\
\hline $\begin{array}{l}\text { REFERENCE } \\
\text { INFORMATION }\end{array}$ & $\begin{array}{l}\text { Low-Level Waste Packing Procedures, 309-WM-96-003 } \\
309 \text { Building Waste Management Program Plan, 309-WM-96-001 } \\
\text { Waste Certification Summary: STEP-OFF PAD WASTE AND LOW-LEVEL DEBRIS } \\
\text { FROM PRTR DEACTIVATION, Rev. O } \\
\text { Waste Specification Record No. 100-00 } \\
\text { Hanford Site Solid Waste Acceptance Criteria, WHC-EP-0063-4 }\end{array}$ \\
\hline
\end{tabular}




\section{WASTE CERTIFICATION SUMMARY}

GENERATOR:

WASTE TYPE:

WSRd NUMBER:

REVISION:

\author{
ADVANCED FUEL FACILITIES TRANSITION \\ VOLUME REDUCED EMPTY DRUMS BY ATG, INC. \\ 102-02, \\ REV. O. MARCH 28, 1996
}

Waste Generating Process Description: The 309 Plutonium Recycle Test Reactor (PRTR) used a contained system for testing called Fuel Element Rupture Test Facility (FERTF) which was a pressurized, light-water-cooled loop, using one of the 85 process tubes within the main, heavywater-cooled PRTR calandria. The FERTF could be operated in a recirculating or once through cooling mode. It was a pilot irradiation facility to test new fuel element designs and new operating regimes. Many of its tests involved testing of pre-defective fuel elements, containing natural uranium and $1 \%$ to $4 \% \mathrm{PuO}_{2}$, with pinhole breaks to study the stability of various defected material under irradiation. The PRTR designed positions for two vaults for spent ion exchange columns. The operating columns were connected in series for removal of the fuel and fission products in the FERTF coolant. The Rupture Loop Annex (RLAIX) contained columns connected in series for removal of products from the test loop.

The north east vault was opened in March, 1994, the vault was found to contain 57,000 liters of radioactive water. The water was due to rain and the vault not having a rain cover. The vault was pumped down to 1,900 liters of water and covered. The water was annualized and found not mixed waste. The water was than shipped to 340 for disposal. The remaining 1,900 liters of water were pumped into metal $\mathbf{5 5}$ gallon drums that were shipped to 340 for disposal of the water. The same drums were used in the pumping of water from the RLAIX vault's IX columns in which the drums were used to ship the water to the 340 facility for disposal.

Physical Description: The waste consists of empty, radiologically contaminated 55 gallon metal drums that were used as transport containers for non-hazardous water from the PRTR facility to the 340 facility for disposal of the water.

Radiological Characterization: The water from the north east IX column vault was analyzed showing ${ }^{60} \mathrm{Co},{ }^{137} \mathrm{Cs}$ and the beta was attributed to ${ }^{90} \mathrm{Sr}$ with trace amounts of ${ }^{14} \mathrm{C}$ and ${ }^{3} \mathrm{H}$. The water pumped from the RLAIX IX columns could contain the following isotopes which were determined to be in the columns using non-destructive assay (NDA) and process knowledge: ${ }^{24}{ }^{24 m},{ }^{233} \mathrm{~Pa},{ }^{237} \mathrm{~Np},{ }^{234} \mathrm{U},{ }^{235} \mathrm{U},{ }^{236} \mathrm{U},{ }^{238} \mathrm{U},{ }^{238} \mathrm{Pu},{ }^{239} \mathrm{Pu},{ }^{240} \mathrm{PU},{ }^{241} \mathrm{Pu},{ }^{242} \mathrm{Pu},{ }^{137} \mathrm{Cs},{ }^{90} \mathrm{Sr}$ and ${ }^{60} \mathrm{Co}$. The empty drums contain low levels of this activity and will be low-level category 1 waste. The laboratory analysis and NDA were done by Battelle. See appendix A for supporting documentation.

Chemical Characterization: The water that was in the drums came from two sources. The first source is the rain water from the north east IX column vault and the second one is water that was pumped from the columns in the RLAIX IX column vault. Laboratory analysis was performed by Battelle. See appendix B for supporting documentation.

Waste Designation: Process knowledge and analysis on the sources of water and the resin with which some of the water was in contact revealed that the water was not regulated by the Washington State Dangerous Waste Regulations Chapter 173-303. Therefore, the empty drums are not regulated for dangerous residues. See appendix B for supporting documentation.

Segregation: The waste consists only of empty radiologically contaminated drums. The drums will be transported to ATG Inc. for volume reduction. ATG Inc. will package the waste after volume reduction and will ensure proper segregation from other waste streams. 
Packaging: The volume reduced drums will be placed in one of the following type of drums: 85 gal., 79 gal., 72 gal., 64 gal. Hanford approved mineral void space filler and or sorbent will be used when needed. The sorbent and void space filler material will be compatible with the waste form.

Waste Minimization: Minimization of waste through use of non-regulated products or materials is the preferred waste management tool. Source reduction for dangerous products/chemicals has been implemented. Source reduction, recycling, and treatment opportunities for all waste streams including sanitary, dangerous, radioactive, and mixed has been implemented.

Please see attachments. 


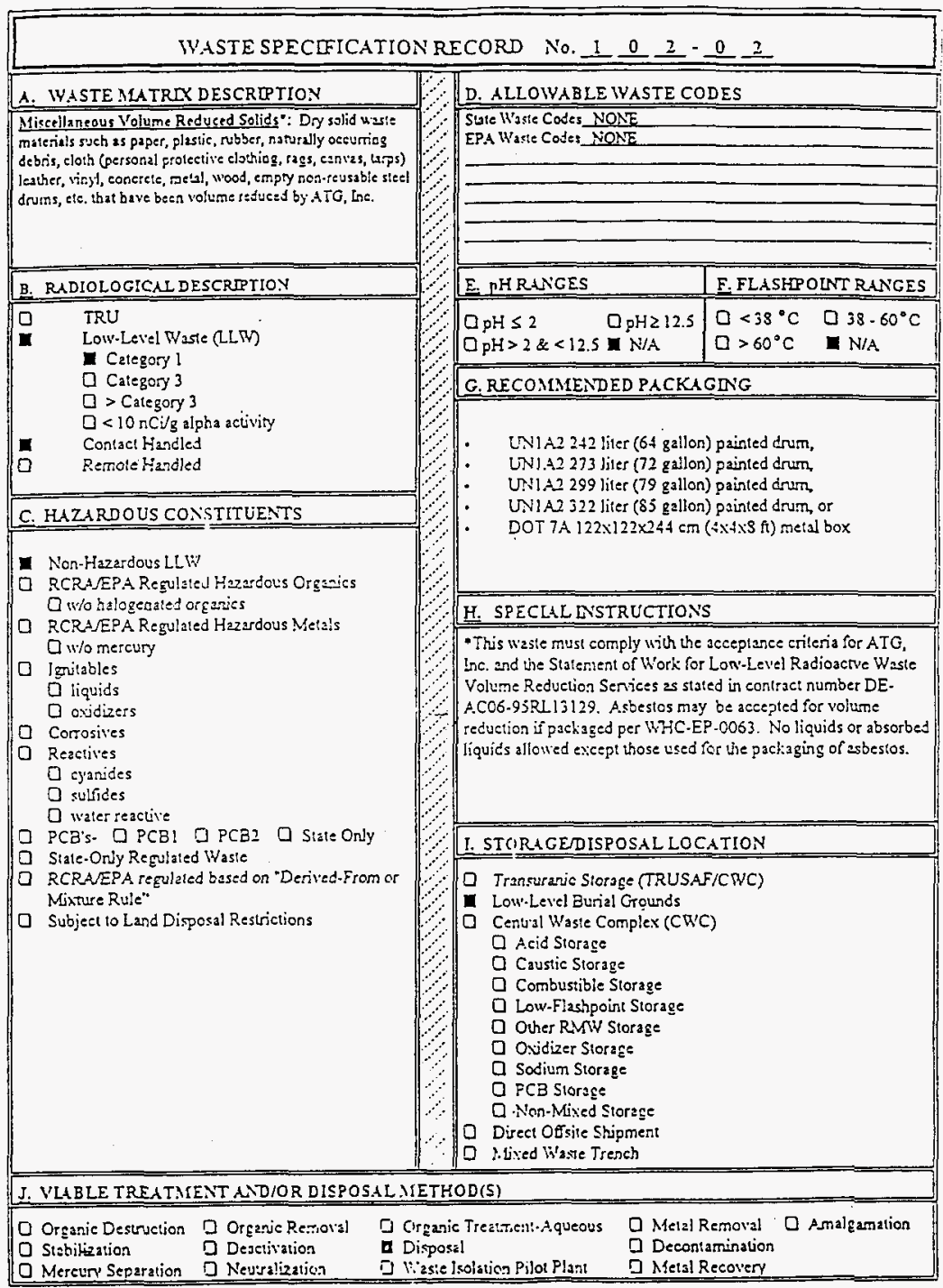




\section{Waste Stream Requirements Summary No. RLA-IXV-03 B}

\begin{tabular}{|c|c|}
\hline $\begin{array}{l}\text { GENERATION } \\
\text { LOCATION }\end{array}$ & $\begin{array}{l}\text { Radioactive Material Storage Areas on the } 309 \text { Building grounds containing empty liquid } \\
\text { bung drums that were used to hold PRTR Vault and RLAIX Vault liquids. }\end{array}$ \\
\hline $\begin{array}{l}\text { PHYSICAL } \\
\text { DESCRIPTION }\end{array}$ & $\begin{array}{l}\text { The waste consists of empty, radiologically contaminated } 55 \text { gallon metal drums that } \\
\text { were used as transport containers for non-hazardous water from the PRTR facility to the } \\
340 \text { facility for disposal of the water. }\end{array}$ \\
\hline $\begin{array}{l}\text { RADIOLOGICAL } \\
\text { CHARACTERISTICS }\end{array}$ & Category 1 Low-Level Waste \\
\hline $\begin{array}{l}\text { DANGEROUS } \\
\text { CHARACTERISTICS }\end{array}$ & Non-Hazardous \\
\hline $\begin{array}{l}\text { DOT HAZARD } \\
\text { CLASSIFICATION }\end{array}$ & Hazard Class 7; Radioactive material, excepted package-limited quantity of material. \\
\hline $\begin{array}{l}\text { PACKAGING } \\
\text { REQUIREMENTS }\end{array}$ & $\begin{array}{l}\text { DOT requirements for Radioactive material, excepted package-limited quantity of material: } \\
\text { 1) UN1A2 } 208 \text { liter ( } 55 \text { gallon) painted drums. } \\
\text { 2) The package does not contain more than } 15 \text { grams of uranium-235. } \\
\text { Hanford Site requirements: } \\
\text { 3) No free liquids or dangerous/hazardous waste will be in the container. }\end{array}$ \\
\hline $\begin{array}{l}\text { MARKING AND } \\
\text { LABELING } \\
\text { REQUIREMENTS }\end{array}$ & $\begin{array}{l}\text { DOT requirements for Radioactive material, excepted package-limited quantity of material: } \\
\text { 1) Radioactive marking. } \\
\text { Hanford Site requirements: } \\
\text { 2) Caution, Radioactive Material Label. } \\
\text { 3) CIN barcode or PIN on one side. }\end{array}$ \\
\hline $\begin{array}{l}\text { TRANSPORTATION } \\
\text { REQUIREMENTS }\end{array}$ & 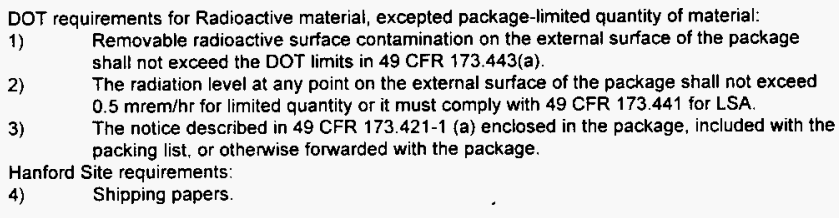 \\
\hline $\begin{array}{l}\text { SPECIAL } \\
\text { INSTRUCTIONS }\end{array}$ & $\begin{array}{l}\text { Hanford Site requirements: } \\
\text { 1) Radiologically characterize each container using dose to curie and scaling factors or } \\
\text { assay and scaling factors. } \\
\text { S) } \\
\text { Acceptance Services. }\end{array}$ \\
\hline $\begin{array}{l}\text { TREATMENT } \\
\text { STORAGE } \\
\text { DISPOSAL } \\
\text { LOCATION(S) }\end{array}$ & $\begin{array}{l}\text { Volume reduction at ATG, Inc. } \\
\text { Disposal at Hanford Site Low-Level Burial Grounds. }\end{array}$ \\
\hline $\begin{array}{l}\text { REFERENCE } \\
\text { INFORMATION }\end{array}$ & $\begin{array}{l}\text { 1) } 309 \text { Building Waste Management Program Plan, 309-WM-96-001 } \\
\text { 2) Waste Certification Summary: VOLUME REDUCED EMPTY DRUMS BY ATG, INC., } \\
\text { Rev. 0 } \\
\text { Waste Specification Record No. 102-02 } \\
\text { 4) Hanford Site Solid Waste Accentance Eriteria, WHC.EP-0063-4 }\end{array}$ \\
\hline
\end{tabular}




\section{Waste Stream Requirements Summary No. RLA-IXV-04 в}

\begin{tabular}{|c|c|}
\hline $\begin{array}{l}\text { GENERATION } \\
\text { LOCATION } \\
\end{array}$ & Rupture Loop Annex Ion Exchanger Vault at the 309 Building \\
\hline $\begin{array}{l}\text { PHYSICAL } \\
\text { DESCRIPTION }\end{array}$ & Water from the RLA lon Exchangers. \\
\hline $\begin{array}{l}\text { RADIOLOGICAL } \\
\text { CHARACTERISTICS }\end{array}$ & Radioactive contaminated liquid. \\
\hline $\begin{array}{l}\text { DANGEROUS } \\
\text { CHARACTERISTICS }\end{array}$ & Non-Hazardous. \\
\hline $\begin{array}{l}\text { DOT HAZARD } \\
\text { CLASSIFICATION }\end{array}$ & To be determined. \\
\hline $\begin{array}{l}\text { PACKAGING } \\
\text { REQUIREMENTS }\end{array}$ & UN1A2 55 gallon painted drums. \\
\hline $\begin{array}{l}\text { MARKING AND } \\
\text { LABELING } \\
\text { REQUIREMENTS }\end{array}$ & $\begin{array}{l}\text { DOT requirements: } \\
\text { 1) To be determined. } \\
\text { Hanford Site requirements: } \\
\text { 2) Caution, Radioactive Material Label. } \\
\text { 3) Radioactive Waste Label on two opposite sides and top. } \\
\text { 4) CIN barcode or PIN on one side. } \\
\text { 5) Others to be determined. }\end{array}$ \\
\hline $\begin{array}{l}\text { TRANSPORTATION } \\
\text { REQUIREMENTS }\end{array}$ & To be determined. \\
\hline $\begin{array}{l}\text { SPECIAL } \\
\text { INSTRUCTIONS }\end{array}$ & $\begin{array}{l}\text { Hanford Site requirements: } \\
\text { 1) Complete sampling and analysis of liquid per Rupture Loop Annex lon Exchange (RLAIX) } \\
\text { Vault Cleanout, 309-WP-96-002, Appendix D. } \\
\text { Submit complete Radioactive Liquid Waste Transfer Request to } 300 \text { Area LEF Facility } \\
\text { Manager. } \\
\text { Others to be determined. }\end{array}$ \\
\hline $\begin{array}{l}\text { TREATMENT } \\
\text { STORAGE } \\
\text { DISPOSAL } \\
\text { LOCATION(S) } \\
\end{array}$ & Acceptance of liquid at 340 Facility. Empty drums will be returned. \\
\hline $\begin{array}{l}\text { REFERENCE } \\
\text { INEORMAIION }\end{array}$ & 309 Building Waste Management Program Plan, 309-WM-96-001. \\
\hline
\end{tabular}




\section{DISTRIBUTION SHEET}

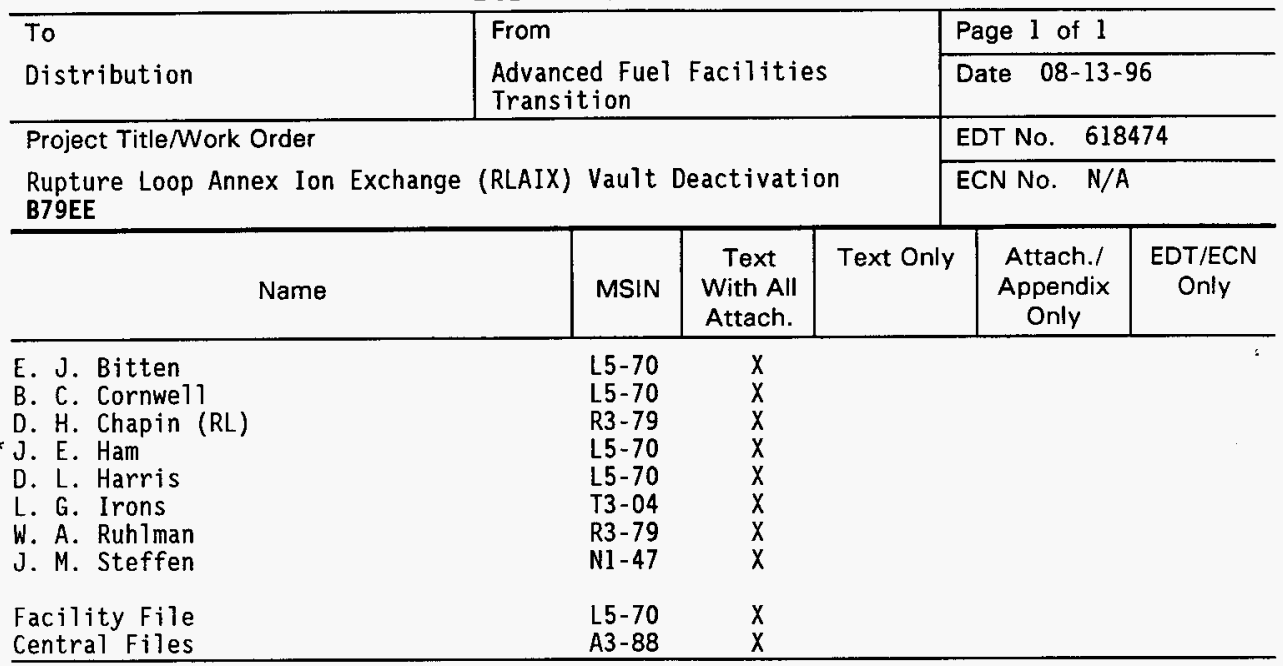

* Advance Copy 